\title{
Application of Trimethylgermanyl-Substituted Bisphosphine Ligands with Enhanced Dispersion Interactions to Copper-Catalyzed Hydroboration of Disubstituted Alkenes
}

\author{
Yumeng Xi ${ }^{a, b, \dagger, *} \mathrm{Bo} \mathrm{Su},{ }^{a, \dagger, \#}$ Xiaotian Qi, ${ }^{c}$ Shayun Pedram, ${ }^{a}$ Peng Liu, ${ }^{*, c}$ and John F. Hartwig ${ }^{*, a, b}$ \\ ${ }^{a}$ Department of Chemistry, University of California, Berkeley, CA 94720, United States \\ ${ }^{b}$ Division of Chemical Sciences, Lawrence Berkeley National Laboratory, Berkeley, CA 94720, United States \\ ${ }^{c}$ Department of Chemistry, University of Pittsburgh, Pittsburgh, Pennsylvania 15260, United States \\ \$Present Address: Materials Research Laboratory, University of California, Santa Barbara, CA 93106, United States \\ ${ }^{\#}$ Present Address: College of Pharmacy, Nankai University, Tianjin, 300071, China \\ †These authors contribute equally to this work \\ Email:jhartwig@berkeley.edu,pengliu@pitt.edu
}




\section{Table of Contents}

$\begin{array}{ll}\text { I. General Methods and Materials } & \text { S3 }\end{array}$

II. General Procedure for Catalytic Hydroboration of 1,1-Disubstituted Alkenes $\quad$ S3

$\begin{array}{ll}\text { III. Compound Characterization } & \text { S4-S10 }\end{array}$

IV. Procedure for Hydroboration of 1,2-Disubstituted Alkenes $\quad$ S11

$\begin{array}{ll}\text { V. Ligand Synthesis } & \text { S11-S17 }\end{array}$

VI. Assignment of Absolute Stereochemistry $\quad$ S17-S19

$\begin{array}{ll}\text { VII. DFT Calculation } & \text { S19-S71 }\end{array}$

$\begin{array}{lr}\text { VIII. SFC Traces } & \text { S72-S83 }\end{array}$

IX. NMR Spectra $\quad$ S84-S123

$\begin{array}{lr}X \text {. References } & \text { S124-S125 }\end{array}$ 


\section{General Methods and Materials}

All reagents were purchased from commercial suppliers, stored in the glove box and used as received. Glassware was dried at $130{ }^{\circ} \mathrm{C}$ for at least 4 hours before use. Decalin was dried over $\mathrm{CaH}_{2}$, degassed, and stored in a dry box. (S)-DTBM-SEGPHOS was used as received from Takasago. Pinacolborane (HBPin) was purchased from Aldrich and stored in a dry box. All catalytic reactions were set up in an argon-filled dry box with oven-dried glassware and were stirred with Teflon-coated magnetic stirring bars. Flash column chromatography was carried out with a Teledyne Isco CombiFlash $\mathrm{R}_{f}$ system using RediSep $\mathrm{R}_{f}$ Gold columns.

${ }^{1} \mathrm{H}$ NMR spectra were recorded on Bruker AV-600 instruments with $600 \mathrm{MHz}$ frequencies, and ${ }^{13} \mathrm{C}$ were recorded on a Bruker AV-600 instrument with a ${ }^{13} \mathrm{C}$ operating frequency of $150 \mathrm{MHz} .{ }^{19} \mathrm{~F}$ NMR spectra were recorded on a Bruker AV-600 spectrometer with a ${ }^{19} \mathrm{~F}$ operating frequency of $564 \mathrm{MHz}$. Chemical shifts $(\delta)$ are reported in ppm relative to the residual solvent signal $\left(\mathrm{CDCl}_{3} \delta=7.26\right.$ for ${ }^{1} \mathrm{H} \mathrm{NMR}$ and $\delta=77.0$ for ${ }^{13} \mathrm{C} \mathrm{NMR}=$ $7.26 \mathrm{ppm}$ ). Quantitative analysis by GC was performed with dodecane as an internal standard. GC analysis was performed on an Agilent $7890 \mathrm{GC}$ equipped with an HP-5 column ( $25 \mathrm{~m} \times 0.20 \mathrm{~mm} \times 0.33 \mu \mathrm{m}$ film) and an FID detector. Chiral SFC analysis was conducted on a JASCO SFC system. Chiral HPLC analysis was conducted on Waters chromatography system. Racemic samples were obtained using racemic DTBM-SEGPHOS as the ligand, which was prepared by mixing equal amounts of ( $S$ )-DTBM-SEGPHOS and $(R)$-DTBM-SEGPHOS.

\section{General Procedure for Catalytic Hydroboration of 1,1-Disubstituted Alkenes}

\section{Representative procedure for the catalytic hydroboration on a $0.2 \mathrm{mmol}$ scale}

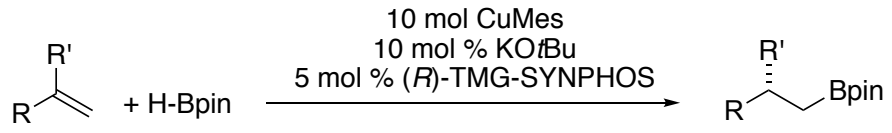

In an argon-filled dry box, a 1-dram vial was charged with CuMes (3.6 mg, $10 \mathrm{~mol} \%$ ), KOtBu (2.2 mg, $10 \mathrm{~mol}$ $\%),(R)$-TMG-SYNPHOS $(15.7 \mathrm{mg}, 5 \mathrm{~mol} \%)$ and decalin $(140 \mu \mathrm{L})$. The mixture was allowed to stir at ambient temperature for 5 minutes before being placed in a freezer at $-40^{\circ} \mathrm{C}$. After 15 minutes, pinacolborane $(35.0 \mu \mathrm{L}$, $0.241 \mathrm{mmol}, 1.2$ equiv) was quickly added while keeping the vial cold, followed by the addition of neat alkene ( $0.2 \mathrm{mmol}, 1$ equiv). The vial was then capped, sealed with electrical tape, removed from the box, and placed in an isopropanol bath at $-15{ }^{\circ} \mathrm{C}$. After $72 \mathrm{~h}$ of stirring at this temperature, the reaction was diluted with $2 \mathrm{~mL}$ of ethyl acetate and the resulting solution was filtered through Celite. The crude material was concentrated in vacuo and purified by flash column chromatography to afford the pure product.

\section{Representative procedure for determination of enantioselectivity}

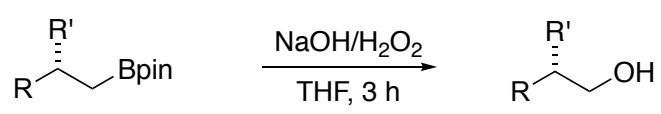

In a $20-\mathrm{mL}$ scintillation vial, the secondary boronate $(5-20 \mathrm{mg})$ was dissolved in $1 \mathrm{~mL}$ THF. The vial was cooled in an ice bath and added a premixed solution of $\mathrm{NaOH}(2 \mathrm{M}$, aq. $) / 30 \% \mathrm{H}_{2} \mathrm{O}_{2}(2: 1,1.5 \mathrm{~mL})$. The reaction was warmed to room temperature and allowed to stir for 2.5 hours before the addition of water $(3 \mathrm{~mL})$ and ethyl acetate 
$(3 \mathrm{~mL})$. The phases were separated, and the aqueous layer was extracted with $3 \mathrm{~mL}$ ethyl acetate. The organic phases were combined, dried over $\mathrm{Na}_{2} \mathrm{SO}_{4}$, and concentrated in vacuo. This material was used for determination of enantioselectivity without further purification.

\section{Compound Characterization}<smiles>CC(CBr)CBr</smiles>

Compound 4a was synthesized according to the General Procedure with 3a (30.0 $\mu \mathrm{L}, 0.204 \mathrm{mmol})$. Compound 4a was purified by flash column chromatography ( $2 \%$ ethyl acetate in hexanes) and obtained as a colorless oil in $80 \%$ yield.

${ }^{1} \mathrm{H}$ NMR $\left(600 \mathrm{MHz}, \mathrm{CDCl}_{3}\right) \delta$ 7.28-7.26 (m, 2H), 7.23-7.09 (m, 3H), $2.63(\mathrm{dd}, J=13.2,6.3 \mathrm{~Hz}, 1 \mathrm{H}), 2.45(\mathrm{dd}$, $J=13.2,7.8 \mathrm{~Hz}, 1 \mathrm{H}), 2.10-1.95(\mathrm{~m}, 1 \mathrm{H}), 1.26(\mathrm{~s}, 12 \mathrm{H}), 0.93(\mathrm{~d}, J=6.5 \mathrm{~Hz}, 3 \mathrm{H}), 0.90(\mathrm{dd}, J=15.4,5.8 \mathrm{~Hz}, 4 \mathrm{H})$, $0.71(\mathrm{dd}, J=15.4,8.5 \mathrm{~Hz}, 1 \mathrm{H})$.

${ }^{13} \mathrm{C}$ NMR $\left(151 \mathrm{MHz}, \mathrm{CDCl}_{3}\right) \delta 141.61,129.26,127.98,125.54,82.85,46.00,31.69,24.88,24.77,21.97,19.55$.

${ }^{11} \mathrm{~B}$ NMR $\left(192 \mathrm{MHz}, \mathrm{CDCl}_{3}\right) \delta 33.4$.

SFC analysis of the corresponding alcohol (OD-H, 10\% IPA/CO $, 10 \mathrm{MPa}, 2.5 \mathrm{~mL} / \mathrm{min}, 220 \mathrm{~nm}$ ) indicated 94:6 er: $t_{R}($ major $)=1.9 \mathrm{~min}, \mathrm{t}_{\mathrm{R}}($ minor $)=2.2 \mathrm{~min}$.<smiles>CCC(CBr)Cc1ccccc1</smiles>

Compound 4b was synthesized with a modification to the General Procedure using $\mathbf{3 b}$ ( $43.9 \mathrm{mg}, 1.5$ equiv) and pinacolborane $(29.0 \mu \mathrm{L}, 0.200 \mathrm{mmol})$. Compound $\mathbf{4 b}$ was purified by flash column chromatography ( $2 \%$ ethyl acetate in hexanes) and obtained as a colorless oil in $58 \%$ yield.

${ }^{1} \mathrm{H}$ NMR (600 MHz, $\left.\mathrm{CDCl}_{3}\right)$ 8 7.28-7.24 (m, 2H), 7.19-7.4 (m, 3H), 2.60-2.50 (m, 2H), 1.89-1.82 (m, 1H), 1.39$1.32(\mathrm{~m}, 1 \mathrm{H}), 1.24(\mathrm{~s}, 12 \mathrm{H}), 1.27-1.19(\mathrm{~m}, 1 \mathrm{H}), 0.88(\mathrm{t}, J=7.4 \mathrm{~Hz}, 3 \mathrm{H}), 0.82-0.72(\mathrm{~m}, 2 \mathrm{H})$.

${ }^{13} \mathrm{C}$ NMR $\left(151 \mathrm{MHz}, \mathrm{CDCl}_{3}\right) \delta 141.70,129.35,127.97,125.47,82.82,42.70,37.88,28.31,24.84,24.83,16.09$, 11.14 .

${ }^{11} \mathrm{~B}$ NMR $\left(192 \mathrm{MHz}, \mathrm{CDCl}_{3}\right) \delta 34.0$.

HRMS (EI+) Calculated for $\mathrm{C}_{17} \mathrm{H}_{27} \mathrm{BO}_{2}[\mathrm{M}]^{+}:$274.2104, Found: 274.2103 .

$[\alpha]_{\mathrm{D}}^{23}=-7.0(\mathrm{c}=0.5, \mathrm{DCM})$.

SFC analysis of the corresponding alcohol (OD-H, 3\% IPA/CO $, 10 \mathrm{MPa}, 2.5 \mathrm{~mL} / \mathrm{min}, 220 \mathrm{~nm}$ ) indicated 95:5 er: $t_{R}($ major $)=3.1 \mathrm{~min}, \mathrm{t}_{\mathrm{R}}($ minor $)=2.9 \mathrm{~min}$. 
<smiles>COCC(CBr)CBr</smiles>

Compound 4c was synthesized according to the General Procedure with $3 \mathbf{c}$ (32.4 $\mathrm{mg}, 0.200 \mathrm{mmol}$ ). Compound $4 \mathbf{c}$ was purified by flash column chromatography ( $2 \%$ ethyl acetate in hexanes) and obtained as a colorless oil in $50 \%$ yield.

${ }^{1} \mathrm{H}$ NMR (600 MHz, $\left.\mathrm{CDCl}_{3}\right) \delta 7.26(\mathrm{t}, J=7.5 \mathrm{~Hz}, 2 \mathrm{H}), 7.20-7.14(\mathrm{~m}, 3 \mathrm{H}), 3.30$ (s, 3H), $3.26(\mathrm{dd}, J=9.1,5.7 \mathrm{~Hz}$, 1H), 3.14 (dd, $J=9.1,6.9 \mathrm{~Hz}, 1 \mathrm{H}), 2.67$ (dd, $J=13.4,7.0 \mathrm{~Hz}, 1 \mathrm{H}), 2.55$ (dd, $J=13.4,7.1 \mathrm{~Hz}, 1 \mathrm{H}), 2.25-2.15$ (m, $1 \mathrm{H}), 1.23(\mathrm{~s}, 12 \mathrm{H}), 0.81(\mathrm{dd}, J=15.5,5.8 \mathrm{~Hz}, 1 \mathrm{H}), 0.74(\mathrm{dd}, J=15.5,8.4 \mathrm{~Hz}, 1 \mathrm{H})$.

${ }^{13} \mathrm{C} \mathrm{NMR}\left(151 \mathrm{MHz}, \mathrm{CDCl}_{3}\right) \delta 140.63,129.39,128.05,125.67,82.81,77.06,58.58,40.25,36.86,24.84,24.79$, 14.39 .

${ }^{11} \mathrm{~B}$ NMR (192 MHz, $\left.\mathrm{CDCl}_{3}\right) \delta 33.7$.

HRMS (EI+) Calculated for $\mathrm{C}_{16} \mathrm{H}_{24} \mathrm{BO}_{3}\left[\mathrm{M}-\mathrm{CH}_{3}\right]^{+}: 275.1819$, Found: 275.1813.

$[\alpha]_{\mathrm{D}}^{23}=4.4(\mathrm{c}=0.57, \mathrm{DCM})$.

SFC analysis of the corresponding alcohol (AD-H, 2\% MeOH/CO $2,10 \mathrm{MPa}, 4.0 \mathrm{~mL} / \mathrm{min}, 220 \mathrm{~nm}$ ) indicated $92: 8$ er: $t_{R}($ major $)=5.5 \mathrm{~min}, \mathrm{t}_{\mathrm{R}}(\operatorname{minor})=6.3 \mathrm{~min}$.

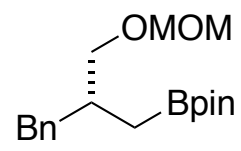

Compound 4d was synthesized according to the General Procedure with 3d (38.4 mg, $0.200 \mathrm{mmol}$ ). Compound 4d was purified by flash column chromatography ( $2 \%$ ethyl acetate in hexanes) and obtained as a colorless oil in $78 \%$ yield.

${ }^{1} \mathrm{H} \mathrm{NMR}\left(600 \mathrm{MHz}, \mathrm{CDCl}_{3}\right) \delta 7.26(\mathrm{t}, J=7.5 \mathrm{~Hz}, 2 \mathrm{H}), 7.23-7.16(\mathrm{~m}, 3 \mathrm{H}), 4.60(\mathrm{~s}, 2 \mathrm{H}), 3.41(\mathrm{dd}, J=9.3,5.5 \mathrm{~Hz}$, $1 \mathrm{H}), 3.35(\mathrm{~s}, 3 \mathrm{H}), 3.34(\mathrm{dd}, J=9.3,6.2 \mathrm{~Hz}, 1 \mathrm{H}), 2.71(\mathrm{dd}, J=13.4,7.1 \mathrm{~Hz}, 1 \mathrm{H}), 2.58(\mathrm{dd}, J=13.4,7.1 \mathrm{~Hz}, 1 \mathrm{H})$, 2.21 (hept, $J=6.9 \mathrm{~Hz}, 1 \mathrm{H}), 0.88-0.78(\mathrm{~m}, 2 \mathrm{H})$.

${ }^{13} \mathrm{C}$ NMR $\left(151 \mathrm{MHz}, \mathrm{CDCl}_{3}\right) \delta 140.64,129.34,128.09,125.72,96.44,82.85,71.86,55.10,40.25,36.98,24.88$, 24.77, 14.29 .

${ }^{11} \mathrm{~B}$ NMR $\left(192 \mathrm{MHz}, \mathrm{CDCl}_{3}\right) \delta 33.7$.

HRMS (EI+) Calculated for $\mathrm{C}_{17} \mathrm{H}_{26} \mathrm{BO}_{4}\left[\mathrm{M}-\mathrm{CH}_{3}\right]^{+}: 305.1924$, Found: 305.1922 .

$[\alpha]_{\mathrm{D}}^{23}=2.8(\mathrm{c}=0.948, \mathrm{DCM})$.

SFC analysis of the corresponding alcohol (AD-H, 5\% MeOH/CO $2,10 \mathrm{MPa}, 2.5 \mathrm{~mL} / \mathrm{min}, 220 \mathrm{~nm})$ indicated $87: 13 \mathrm{er}: \mathrm{t}_{\mathrm{R}}($ major $)=4.4 \mathrm{~min}, \mathrm{t}_{\mathrm{R}}($ minor $)=4.7 \mathrm{~min}$.<smiles>Brc1ccc(Br)cc1</smiles> 
Compound 4e was synthesized according to the General Procedure with $3 \mathbf{e}$ ( $52.5 \mathrm{mg}, 0.200 \mathrm{mmol}$ ). Compound 4e was purified by flash column chromatography ( $2 \%$ ethyl acetate in hexanes) and obtained as a colorless oil in $71 \%$ yield.

${ }^{1} \mathrm{H}$ NMR $\left(600 \mathrm{MHz}, \mathrm{CDCl}_{3}\right) \delta 7.26(\mathrm{~d}, J=7.5 \mathrm{~Hz}, 2 \mathrm{H}), 7.22-7.15(\mathrm{~m}, 3 \mathrm{H}), 3.50(\mathrm{dd}, J=9.7,4.7 \mathrm{~Hz}, 1 \mathrm{H}), 3.40$ $(\mathrm{dd}, J=9.8,6.1 \mathrm{~Hz}, 1 \mathrm{H}), 2.80(\mathrm{dd}, J=13.2,6.9 \mathrm{~Hz}, 1 \mathrm{H}), 2.51(\mathrm{dd}, J=13.2,7.0 \mathrm{~Hz}, 1 \mathrm{H}), 2.08-1.99(\mathrm{~m}, 1 \mathrm{H}), 1.24$ (s, 12H), 0.93 (s, 9H), 0.80 (d, $J=7.2 \mathrm{~Hz}, 2 \mathrm{H}), 0.05$ (s, 3H, 0.04 (s, 3H).

${ }^{13} \mathrm{C}$ NMR $\left(151 \mathrm{MHz}, \mathrm{CDCl}_{3}\right) \delta 141.21,129.49,127.96,125.51,82.84,66.29,39.41,39.10,25.96,24.87,24.82$, $18.31,13.18,-5.34,-5.39$.

${ }^{11} \mathrm{~B}$ NMR (192 MHz, $\left.\mathrm{CDCl}_{3}\right) \delta 34.0$.

HRMS (ESI+) Calculated for $\mathrm{C}_{20} \mathrm{H}_{40} \mathrm{BO}_{3} \mathrm{Si}[\mathrm{M}+\mathrm{H}]^{+}: 391.2834$, Found: 391.2823.

$[\alpha]_{\mathrm{D}}^{23}=5.0(\mathrm{c}=1.0, \mathrm{DCM})$.

SFC analysis of the corresponding alcohol (AD-H, 5\% IPA/CO $2,10 \mathrm{MPa}, 2.5 \mathrm{~mL} / \mathrm{min}, 220 \mathrm{~nm}$ ) indicated 93:7 er: $\mathrm{t}_{\mathrm{R}}($ major $)=1.8 \mathrm{~min}, \mathrm{t}_{\mathrm{R}}($ minor $)=2.1 \mathrm{~min}$.

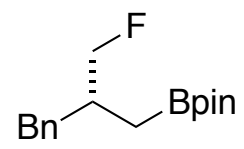

Compound $4 \mathbf{f}$ was synthesized according to the General Procedure with $3 f(30.0 \mathrm{mg}, 0.200 \mathrm{mmol})$. Compound 4f was purified by flash column chromatography ( $2 \%$ ethyl acetate in hexane) and obtained as a colorless oil in $72 \%$ yield.

${ }^{1} \mathrm{H} \mathrm{NMR}\left(600 \mathrm{MHz}, \mathrm{CDCl}_{3}\right) \delta 7.28(\mathrm{t}, J=7.4 \mathrm{~Hz}, 2 \mathrm{H}), 7.24-7.16(\mathrm{~m}, 3 \mathrm{H}), 4.28(\mathrm{dd}, J=47.7,5.5 \mathrm{~Hz}, 2 \mathrm{H}), 2.72$ $(\mathrm{dd}, J=13.5,7.4 \mathrm{~Hz}, 1 \mathrm{H}), 2.61(\mathrm{dd}, J=13.5,6.9 \mathrm{~Hz}, 1 \mathrm{H}), 2.31-2.19(\mathrm{~m}, 1 \mathrm{H}), 1.24(\mathrm{~s}, 12 \mathrm{H}), 0.91-0.79(\mathrm{~m}, 1 \mathrm{H})$. ${ }^{13} \mathrm{C}$ NMR $\left(151 \mathrm{MHz}, \mathrm{CDCl}_{3}\right) \delta 139.88,129.35,128.21,125.95,86.93(\mathrm{~d}, J=168.4 \mathrm{~Hz}), 83.10,38.96,37.48(\mathrm{~d}, J$ $=18.2 \mathrm{~Hz}), 24.81,24.77,13.11$.

${ }^{11} \mathrm{~B}$ NMR (192 MHz, $\left.\mathrm{CDCl}_{3}\right) \delta 33.7$.

${ }^{19} \mathrm{~F}$ NMR $\left(564 \mathrm{MHz}, \mathrm{CDCl}_{3}\right) \delta-224.61(\mathrm{td}, J=47.7,21.0 \mathrm{~Hz})$.

HRMS (EI+) Calculated for $\mathrm{C}_{16} \mathrm{H}_{23} \mathrm{BO}_{2}[\mathrm{M}-\mathrm{HF}]^{+}: 258.1791$, Found: 258.1788 .

$[\alpha]_{\mathrm{D}}^{23}=10.7(\mathrm{c}=0.656, \mathrm{DCM})$.

SFC analysis of the corresponding alcohol (IC-H, 3\% IPA/CO $, 10 \mathrm{MPa}, 2.5 \mathrm{~mL} / \mathrm{min}, 220 \mathrm{~nm}$ ) indicated 97:3 er: $\mathrm{t}_{\mathrm{R}}($ major $)=4.0 \mathrm{~min}, \mathrm{t}_{\mathrm{R}}(\mathrm{minor})=3.7 \mathrm{~min}$.<smiles>COc1ccc(C[C@@H](C)Cc2ccccc2)cc1</smiles>

Compound $\mathbf{4 g}$ was synthesized according to the General Procedure with $\mathbf{3 g}$ (32.4 $\mathrm{mg}, 0.200 \mathrm{mmol})$. Compound $4 \mathbf{g}$ was purified by flash column chromatography ( $5 \%$ ethyl acetate in hexanes) and obtained as a colorless oil in $66 \%$ yield. 
${ }^{1} \mathrm{H}$ NMR $\left(600 \mathrm{MHz}, \mathrm{CDCl}_{3}\right) \delta 7.07(\mathrm{~d}, J=8.5 \mathrm{~Hz}, 2 \mathrm{H}), 6.81(\mathrm{~d}, J=8.5 \mathrm{~Hz}, 1 \mathrm{H}), 3.78(\mathrm{~s}, 3 \mathrm{H}), 2.54(\mathrm{dd}, J=13.4$, $6.4 \mathrm{~Hz}, 1 \mathrm{H}), 2.38(\mathrm{dd}, J=13.4,7.8 \mathrm{~Hz}, 1 \mathrm{H}), 2.00-1.91(\mathrm{~m}, 1 \mathrm{H}), 1.24(\mathrm{~d}, J=1.8 \mathrm{~Hz}, 12 \mathrm{H}), 0.89(\mathrm{~d}, J=6.7 \mathrm{~Hz}$, $3 \mathrm{H}), 0.87(\mathrm{dd}, J=15.2,5.8 \mathrm{~Hz}, 1 \mathrm{H}), 0.67$ (dd, $J=15.5,8.6 \mathrm{~Hz}, 1 \mathrm{H})$.

${ }^{13} \mathrm{C}$ NMR $\left(151 \mathrm{MHz}, \mathrm{CDCl}_{3}\right) \delta 157.59,133.72,130.11,113.39,82.84,55.17,45.08,31.82,24.88,24.76,21.92$, 19.48 .

${ }^{11} \mathrm{~B}$ NMR (192 MHz, $\left.\mathrm{CDCl}_{3}\right) \delta 33.5$.

HRMS (EI+) Calculated for $\mathrm{C}_{17} \mathrm{H}_{27} \mathrm{BO}_{3}[\mathrm{M}]^{+}:$290.2053, Found: 290.2056 .

$[\alpha]_{\mathrm{D}}^{23}=5.7(\mathrm{c}=0.51, \mathrm{DCM})$.

SFC analysis of the corresponding alcohol (OJ-H, 5\% IPA/CO $2,10 \mathrm{MPa}, 2.5 \mathrm{~mL} / \mathrm{min}, 220 \mathrm{~nm}$ ) indicated 92:8 er: $\mathrm{t}_{\mathrm{R}}($ major $)=3.5 \mathrm{~min}, \mathrm{t}_{\mathrm{R}}($ minor $)=3.2 \mathrm{~min}$.<smiles>CC(Cc1ccccc1)Cc1cc(C(F)(F)F)cc(C(F)(F)F)c1</smiles>

Compound 4h was synthesized according to the General Procedure with $\mathbf{3 h}$ ( $53.6 \mathrm{mg}, 0.200 \mathrm{mmol})$. Compound 4h was purified by flash column chromatography ( $2 \%$ ethyl acetate in hexanes) and obtained as a colorless oil in $81 \%$ yield.

${ }^{1} \mathrm{H}$ NMR (600 MHz, CDCl $) \delta 7.69(\mathrm{~s}, 1 \mathrm{H}), 7.61(\mathrm{~s}, 2 \mathrm{H}), 2.74(\mathrm{dd}, J=13.4,6.5 \mathrm{~Hz}, 1 \mathrm{H}), 2.57$ (dd, $J=13.4,7.7$ $\mathrm{Hz}, 1 \mathrm{H}), 2.09-1.98(\mathrm{~m}, 1 \mathrm{H}), 1.25(\mathrm{~s}, 12 \mathrm{H}), 0.93(\mathrm{~d}, J=6.6 \mathrm{~Hz}, 3 \mathrm{H}), 0.86(\mathrm{dd}, J=15.6,5.7 \mathrm{~Hz}, 1 \mathrm{H}), 0.71(\mathrm{dd}, J=$ $15.6,8.2 \mathrm{~Hz}, 1 \mathrm{H})$.

${ }^{13} \mathrm{C}$ NMR $\left(151 \mathrm{MHz}, \mathrm{CDCl}_{3}\right) \delta 143.98,131.18(\mathrm{q}, J=33.1 \mathrm{~Hz}), 129.28,123.45$ (q, $\left.J=272.6 \mathrm{~Hz}\right), 120.14-119.52$ (m), 83.06, 45.21, 31.53, 24.80, 24.68, 21.77, 19.04 .

${ }^{11} \mathrm{~B}$ NMR $\left(192 \mathrm{MHz}, \mathrm{CDCl}_{3}\right) \delta 32.8$.

${ }^{19} \mathrm{~F}$ NMR $\left(564 \mathrm{MHz}, \mathrm{CDCl}_{3}\right) \delta-64.5(\mathrm{~m})$.

HRMS (EI+) Calculated for $\mathrm{C}_{18} \mathrm{H}_{23} \mathrm{BF}_{6} \mathrm{O}_{2}[\mathrm{M}]^{+}: 396.1695$, Found: 396.1702 .

$[\alpha]_{\mathrm{D}}^{23}=7.5(\mathrm{c}=0.924, \mathrm{DCM})$.

${ }^{1} \mathrm{H}$ and ${ }^{19} \mathrm{~F}$ NMR analysis of the Mosher ester of the corresponding alcohol indicated 91:9 er.

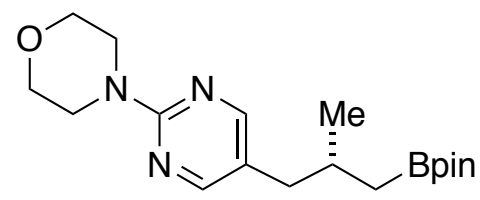

Compound 4i was synthesized according to the General Procedure with $3 i$ (43.9 mg, $0.200 \mathrm{mmol}$ ). Compound $4 \mathbf{i}$ was purified by flash column chromatography (10\% ethyl acetate in hexanes) and obtained as a white solid in $93 \%$ yield. 
${ }^{1} \mathrm{H}$ NMR $\left(600 \mathrm{MHz}, \mathrm{CDCl}_{3}\right) \delta 8.11(\mathrm{~s}, 2 \mathrm{H}), 3.75-3.68(\mathrm{~m}, 8 \mathrm{H}), 2.36(\mathrm{dd}, J=13.8,6.6 \mathrm{~Hz}, 1 \mathrm{H}), 2.25(\mathrm{dd}, J=13.8$, $7.4 \mathrm{~Hz}, 1 \mathrm{H}), 1.90-1.80(\mathrm{~m}, 1 \mathrm{H}), 1.20(\mathrm{~s}, 12 \mathrm{H}), 0.88(\mathrm{~d}, J=6.6 \mathrm{~Hz}, 3 \mathrm{H}), 0.80(\mathrm{dd}, J=15.5,5.8 \mathrm{~Hz}, 1 \mathrm{H}), 0.62(\mathrm{dd}$, $J=15.5,8.3 \mathrm{~Hz}, 1 \mathrm{H})$.

${ }^{13} \mathrm{C}$ NMR $\left(151 \mathrm{MHz}, \mathrm{CDCl}_{3}\right) \delta 160.79,158.05,122.43,82.91,66.76,44.33,39.09,31.42,24.84,24.72,21.74$, 18.69 .

${ }^{11} \mathrm{~B}$ NMR (192 MHz, $\left.\mathrm{CDCl}_{3}\right) \delta 33.7$.

HRMS (ESI+) Calculated for $\mathrm{C}_{18} \mathrm{H}_{31} \mathrm{BN}_{3} \mathrm{O}_{3}[\mathrm{M}+\mathrm{H}]^{+}: 348.2453$, Found: 348.2469.

$[\alpha]_{\mathrm{D}}^{23}=3.4(\mathrm{c}=0.943, \mathrm{DCM})$.

SFC analysis of the corresponding alcohol (AD-H, 20\% IPA/CO $, 10 \mathrm{MPa}, 2.5 \mathrm{~mL} / \mathrm{min}, 220 \mathrm{~nm}$ ) indicated 93:7 er: $\mathrm{t}_{\mathrm{R}}($ major $)=2.2 \mathrm{~min}, \mathrm{t}_{\mathrm{R}}($ minor $)=2.0 \mathrm{~min}$.

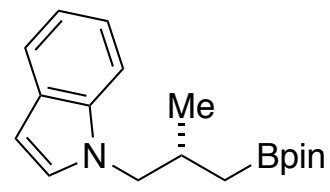

Compound $\mathbf{4 j}$ was synthesized according to the General Procedure with $\mathbf{3 j}$ ( $34.2 \mathrm{mg}, 0.200 \mathrm{mmol}$ ). Compound $\mathbf{4 j}$ was purified by flash column chromatography (5\% ethyl acetate in hexanes) and obtained as a colorless oil in $85 \%$ yield.

${ }^{1} \mathrm{H}$ NMR $\left(600 \mathrm{MHz}, \mathrm{CDCl}_{3}\right) \delta 7.67(\mathrm{~d}, J=7.9 \mathrm{~Hz}, 1 \mathrm{H}), 7.47(\mathrm{~d}, J=8.2 \mathrm{~Hz}, 1 \mathrm{H}), 7.24(\mathrm{t}, J=7.5 \mathrm{~Hz}, 1 \mathrm{H}), 7.21-$ 7.10 (m, 2H), 6.52 (d, $J=2.9 \mathrm{~Hz}, 1 \mathrm{H}), 4.11$ (dd, $J=14.1,6.5 \mathrm{~Hz}, 1 \mathrm{H}), 3.89$ (dd, $J=14.1,8.2 \mathrm{~Hz}, 1 \mathrm{H}), 2.45-2.29$ $(\mathrm{m}, 1 \mathrm{H}), 1.30(\mathrm{~s}, 12 \mathrm{H}), 0.97(\mathrm{~d}, J=6.6 \mathrm{~Hz}, 3 \mathrm{H}), 0.91(\mathrm{dd}, J=15.8,6.1 \mathrm{~Hz}, 1 \mathrm{H}), 0.79(\mathrm{dd}, J=15.8,8.0 \mathrm{~Hz}, 1 \mathrm{H})$. ${ }^{13} \mathrm{C}$ NMR $\left(151 \mathrm{MHz}, \mathrm{CDCl}_{3}\right) \delta 136.33,128.58,128.51,121.17,120.78,119.06,109.87,100.63,83.17,54.42$, $30.87,24.95,24.84,20.29,17.20$.

${ }^{11} \mathrm{~B}$ NMR $\left(192 \mathrm{MHz}, \mathrm{CDCl}_{3}\right) \delta 33.8$.

HRMS (ESI+) Calculated for $\mathrm{C}_{19} \mathrm{H}_{26} \mathrm{~B}^{35} \mathrm{Cl}_{3} \mathrm{O}_{4}[\mathrm{M}+\mathrm{H}]^{+}: 300.2129$, Found: 300.2138 .

$[\alpha]_{\mathrm{D}}^{23}=17.4(\mathrm{c}=0.5, \mathrm{DCM})$.

SFC analysis of the corresponding alcohol (OD-H, 15\% IPA/CO $2,10 \mathrm{MPa}, 2.5 \mathrm{~mL} / \mathrm{min}, 220 \mathrm{~nm}$ ) indicated 90:10 er: $t_{R}($ major $)=3.3 \mathrm{~min}, t_{R}($ minor $)=3.0 \mathrm{~min}$.

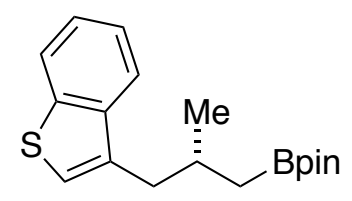

Compound 4k was synthesized according to the General Procedure with 3k (37.6 mg, 0.200 mmol). Compound $4 \mathbf{k}$ was purified by flash column chromatography ( $4 \%$ ethyl acetate in hexanes) and obtained as a colorless oil in $87 \%$ yield. 
${ }^{1} \mathrm{H}$ NMR $\left(600 \mathrm{MHz}, \mathrm{CDCl}_{3}\right) \delta 7.87(\mathrm{t}, J=8.7 \mathrm{~Hz}, 2 \mathrm{H}), 7.48-7.32(\mathrm{~m}, 2 \mathrm{H}), 7.09$ (s, 1H), 2.89 (dd, $J=14.0,6.1$ $\mathrm{Hz}, 1 \mathrm{H}), 2.68(\mathrm{dd}, J=14.0,8.1 \mathrm{~Hz}, 1 \mathrm{H}), 2.25-2.18(\mathrm{~m}, 1 \mathrm{H}), 1.27$ (s, 12H), 0.99 (d, $J=6.4 \mathrm{~Hz}, 3 \mathrm{H}), 0.99-0.94$ (m, $1 \mathrm{H}), 0.81(\mathrm{dd}, J=15.6,7.8 \mathrm{~Hz}, 1 \mathrm{H})$.

${ }^{13} \mathrm{C}$ NMR $\left(151 \mathrm{MHz}, \mathrm{CDCl}_{3}\right) \delta 140.42,139.45,136.15,123.87,123.59,122.72,122.22,122.05,82.96,38.53$, 29.90, 24.94, 24.81, 22.55, 19.84 .

${ }^{11} \mathrm{~B}$ NMR (192 MHz, $\left.\mathrm{CDCl}_{3}\right) \delta 33.9$.

HRMS (EI+) Calculated for $\mathrm{C}_{18} \mathrm{H}_{25} \mathrm{BO}_{2} \mathrm{~S}[\mathrm{M}]^{+}: 316.1668$, Found: 316.1671 .

$[\alpha]_{\mathrm{D}}^{23}=9.0(\mathrm{c}=1.0, \mathrm{DCM})$.

SFC analysis of the corresponding alcohol (AD-H, 10\% IPA/CO $2,10 \mathrm{MPa}, 2.5 \mathrm{~mL} / \mathrm{min}, 220 \mathrm{~nm}$ ) indicated $86: 14$ er: $t_{R}($ major $)=4.7 \mathrm{~min}, t_{R}($ minor $)=5.1 \mathrm{~min}$.

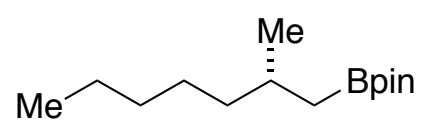

Compound $4 \mathbf{l}$ was synthesized according to the General Procedure with 31 ( $31.5 \mu \mathrm{L}, 0.200 \mathrm{mmol})$. Compound $4 \mathbf{l}$ was purified by flash column chromatography ( $2 \%$ ethyl acetate in hexanes) and obtained as a colorless oil in $81 \%$ yield.

${ }^{1} \mathrm{H}$ NMR $\left(600 \mathrm{MHz}, \mathrm{CDCl}_{3}\right) \delta 1.69-1.62(\mathrm{~m}, 1 \mathrm{H}), 1.23(\mathrm{~s}, 12 \mathrm{H}), 1.32-1.10(\mathrm{~m}, 8 \mathrm{H}), 0.89(\mathrm{~d}, J=6.7 \mathrm{~Hz}, 3 \mathrm{H}), 0.86$ $(\mathrm{t}, J=7.1 \mathrm{~Hz}, 3 \mathrm{H}), 0.81(\mathrm{dd}, J=15.3,5.9 \mathrm{~Hz}, 1 \mathrm{H}), 0.62(\mathrm{dd}, J=15.3,8.3 \mathrm{~Hz}, 1 \mathrm{H})$.

${ }^{13} \mathrm{C} \mathrm{NMR}\left(151 \mathrm{MHz}, \mathrm{CDCl}_{3}\right) \delta 82.70,39.55,32.08,29.44,26.93,24.80,24.72,22.62,22.34,19.68,14.04$.

${ }^{11} \mathrm{~B}$ NMR $\left(192 \mathrm{MHz}, \mathrm{CDCl}_{3}\right) \delta 33.0$.

${ }^{1} \mathrm{H}$ NMR analysis of the Mosher ester of the corresponding alcohol indicated 88:12 er.<smiles>CC(C)CC(C)CCc1ccccc1</smiles>

Compound $\mathbf{4 m}$ was synthesized according to the General Procedure with an alteration. The reaction was carried out with alkene $3 \mathbf{m}\left(84.6 \mu \mathrm{L}, 3\right.$ equiv) and HBpin $(29.0 \mu \mathrm{L}, 0.200 \mathrm{mmol})$ at $-5{ }^{\circ} \mathrm{C}$ for $72 \mathrm{~h}$. Compound $4 \mathbf{m}$ was purified by flash column chromatography ( $2 \%$ ethyl acetate in hexanes) and obtained as a colorless oil in $80 \%$ yield.

${ }^{1} \mathrm{H}$ NMR $\left(600 \mathrm{MHz}, \mathrm{CDCl}_{3}\right) \delta 1.77-1.70(\mathrm{~m}, 1 \mathrm{H}), 1.62-1.54(\mathrm{~m}, 1 \mathrm{H}), 1.22(\mathrm{~s}, 12 \mathrm{H}), 1.09-0.99(\mathrm{~m}, 2 \mathrm{H}), 0.86(\mathrm{~d}$, $J=6.6 \mathrm{~Hz}, 3 \mathrm{H}), 0.82(\mathrm{~d}, J=6.6 \mathrm{~Hz}, 3 \mathrm{H}), 0.81(\mathrm{~d}, J=6.6 \mathrm{~Hz}, 3 \mathrm{H}), 0.77(\mathrm{dd}, J=15.2,5.8 \mathrm{~Hz}, 1 \mathrm{H}), 0.59(\mathrm{dd}, J=$ $15.2,8.2 \mathrm{~Hz}, 1 \mathrm{H})$.

${ }^{13} \mathrm{C}$ NMR $\left(151 \mathrm{MHz}, \mathrm{CDCl}_{3}\right) \delta 82.68,49.31,26.98,25.39,24.78,24.73,23.21,22.39,20.07$.

${ }^{11} \mathrm{~B}$ NMR (192 MHz, $\left.\mathrm{CDCl}_{3}\right) \delta 33.7$.

${ }^{1} \mathrm{H}$ NMR analysis of the Mosher ester of the corresponding alcohol indicated 86:14 er. 
<smiles>CC(CCc1ccccc1)CCc1ccccc1</smiles>

Compound 4n was synthesized according to the General Procedure with 3n (29.2 mg, $0.200 \mathrm{mmol})$. Compound $4 \mathbf{n}$ was purified by flash column chromatography ( $2 \%$ ethyl acetate in hexanes) and obtained as a colorless oil in $83 \%$ yield.

${ }^{1} \mathrm{H}$ NMR $\left(600 \mathrm{MHz}, \mathrm{CDCl}_{3}\right) \delta 7.28(\mathrm{t}, J=7.5 \mathrm{~Hz}, 2 \mathrm{H}), 7.21-7.16(\mathrm{~m}, 3 \mathrm{H}), 2.68-2.58(\mathrm{~m}, 2 \mathrm{H}), 1.83-1.78(\mathrm{~m}$, $1 \mathrm{H}), 1.68-1.59(\mathrm{~m}, 1 \mathrm{H}), 1.56-1.48(\mathrm{~m}, 1 \mathrm{H}), 1.27(\mathrm{~s}, 12 \mathrm{H}), 1.01(\mathrm{~d}, J=6.7 \mathrm{~Hz}, 3 \mathrm{H}), 0.92(\mathrm{dd}, J=15.4,5.8 \mathrm{~Hz}$, $1 \mathrm{H}), 0.74(\mathrm{dd}, J=15.3,8.3 \mathrm{~Hz}, 1 \mathrm{H})$.

${ }^{13} \mathrm{C}$ NMR $\left(151 \mathrm{MHz}, \mathrm{CDCl}_{3}\right) \delta 143.16,128.32,128.19,125.44,82.85,41.52,33.77,29.38,24.87,24.80,22.26$, 19.56.

${ }^{11} \mathrm{~B}$ NMR $\left(192 \mathrm{MHz}, \mathrm{CDCl}_{3}\right) \delta 33.7$.

HRMS (EI+) Calculated for $\mathrm{C}_{17} \mathrm{H}_{27} \mathrm{BO}_{2}[\mathrm{M}]^{+}:$274.2104, Found: 274.2100 .

$[\alpha]_{\mathrm{D}}{ }^{23}=-4.4(\mathrm{c}=0.858, \mathrm{DCM})$.

SFC analysis of the corresponding alcohol (AD-H, 2\% MeOH/CO $/ 2$, 10 Pa, $4.0 \mathrm{~mL} / \mathrm{min}, 220 \mathrm{~nm}$ ) indicated $86: 14$ er: $\mathrm{t}_{\mathrm{R}}($ major $)=5.3 \mathrm{~min}, \mathrm{t}_{\mathrm{R}}($ minor $)=5.6 \mathrm{~min}$.

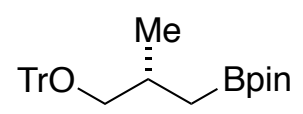

Compound 40 was synthesized according to the General Procedure with an alteration. The reaction was carried out with alkene $30(62.9 \mathrm{mg}, 0.200 \mathrm{mmol})$ and $\mathrm{HBpin}\left(35.0 \mu \mathrm{L}, 1.2\right.$ equiv) in decalin $(600 \mu \mathrm{L})$ at $-5{ }^{\circ} \mathrm{C}$ for $72 \mathrm{~h}$. Compound 40 was purified by flash column chromatography (5\% ethyl acetate in hexanes) and obtained as a colorless oil in $90 \%$ yield.

${ }^{1} \mathrm{H} \mathrm{NMR}\left(600 \mathrm{MHz}, \mathrm{CDCl}_{3}\right) \delta$ 7.52-7.43 (m, 6H), $7.30(\mathrm{t}, J=7.6 \mathrm{~Hz}, 6 \mathrm{H}), 7.26-7.19(\mathrm{~m}, 3 \mathrm{H}), 2.97(\mathrm{dd}, J=8.5$, $5.6 \mathrm{~Hz}, 1 \mathrm{H}), 2.84(\mathrm{dd}, J=8.5,7.1 \mathrm{~Hz}, 1 \mathrm{H}), 1.22(\mathrm{~s}, 6 \mathrm{H}), 1.21(\mathrm{~s}, 6 \mathrm{H}), 1.05(\mathrm{~d}, J=6.7 \mathrm{~Hz}, 3 \mathrm{H}), 0.97$ (dd, $J=15.6$, $5.8 \mathrm{~Hz}, 1 \mathrm{H}), 0.69$ (dd, $J=15.6,8.8 \mathrm{~Hz}, 1 \mathrm{H})$.

${ }^{13} \mathrm{C}$ NMR $\left(151 \mathrm{MHz}, \mathrm{CDCl}_{3}\right) \delta 144.57,128.81,127.59,126.68,85.96,82.85,69.94,30.45,24.84,24.73,19.91$, 16.45 .

${ }^{11} \mathrm{~B}$ NMR (192 MHz, $\left.\mathrm{CDCl}_{3}\right) \delta 33.9$.

HRMS (EI+) Calculated for $\mathrm{C}_{29} \mathrm{H}_{35} \mathrm{BO}_{3}[\mathrm{M}]^{+}: 442.2679$, Found: 442.2682 .

$[\alpha]_{\mathrm{D}}^{23}=-8.1(\mathrm{c}=0.942, \mathrm{DCM})$.

SFC analysis of the corresponding alcohol (AD-H, 10\% IPA/CO $, 10 \mathrm{MPa}, 2.5 \mathrm{~mL} / \mathrm{min}, 220 \mathrm{~nm}$ ) indicated 91:9 er: $t_{\mathrm{R}}($ major $)=4.3 \mathrm{~min}, \mathrm{t}_{\mathrm{R}}($ minor $)=3.7 \mathrm{~min}$. 
<smiles>C[C@H](CBr)CN(C)c1ccccc1</smiles>

Compound 4p was synthesized according to the General Procedure with 3p (32.2 $\mathrm{mg}, 0.200 \mathrm{mmol}$ ). Compound $4 \mathbf{p}$ was purified by flash column chromatography (10\% ethyl acetate in hexanes) and obtained as a yellow oil in $52 \%$ yield.

${ }^{1} \mathrm{H} \mathrm{NMR}\left(600 \mathrm{MHz}, \mathrm{CDCl}_{3}\right) \delta 7.22(\mathrm{t}, J=7.1 \mathrm{~Hz}, 2 \mathrm{H}), 6.74(\mathrm{~d}, J=8.2 \mathrm{~Hz}, 2 \mathrm{H}), 6.67(\mathrm{t}, J=7.2 \mathrm{~Hz}, 1 \mathrm{H}), 3.23(\mathrm{dd}$, $J=14.5,6.7 \mathrm{~Hz}, 1 \mathrm{H}), 3.01(\mathrm{dd}, J=14.5,8.2 \mathrm{~Hz}, 1 \mathrm{H}), 2.96$ (s, 3H), 2.27-2.15 (m, 1H), $1.26(\mathrm{~s}, 6 \mathrm{H}), 1.25(\mathrm{~s}, 6 \mathrm{H})$, $0.97(\mathrm{~d}, J=6.6 \mathrm{~Hz}, 3 \mathrm{H}), 0.88$ (dd, $J=15.6,6.5 \mathrm{~Hz}, 1 \mathrm{H}), 0.71(\mathrm{dd}, J=15.6,7.8 \mathrm{~Hz}, 1 \mathrm{H})$.

${ }^{13} \mathrm{C}$ NMR $\left(151 \mathrm{MHz}, \mathrm{CDCl}_{3}\right) \delta 149.79,128.93,115.55,111.92,82.97,61.59,39.44,28.93,24.92,24.79,20.48$, 17.20 .

${ }^{11} \mathrm{~B}$ NMR (192 MHz, $\left.\mathrm{CDCl}_{3}\right) \delta 33.2$.

HRMS (ESI+) Calculated for $\mathrm{C}_{17} \mathrm{H}_{29} \mathrm{BNO}_{2}[\mathrm{M}+\mathrm{H}]^{+}: 290.2286$, Found: 290.2294.

$[\alpha]_{\mathrm{D}}^{23}=5.2(\mathrm{c}=0.5, \mathrm{DCM})$.

SFC analysis of the corresponding alcohol (OD-H, 3\% IPA/CO $2,10 \mathrm{MPa}, 2.5 \mathrm{~mL} / \mathrm{min}, 220 \mathrm{~nm}$ ) indicated 90:10 er: $\mathrm{t}_{\mathrm{R}}($ major $)=3.1 \mathrm{~min}, \mathrm{t}_{\mathrm{R}}($ minor $)=2.7 \mathrm{~min}$.

\section{Procedure for Hydroboration of 1,2-Disubstituted Alkenes}

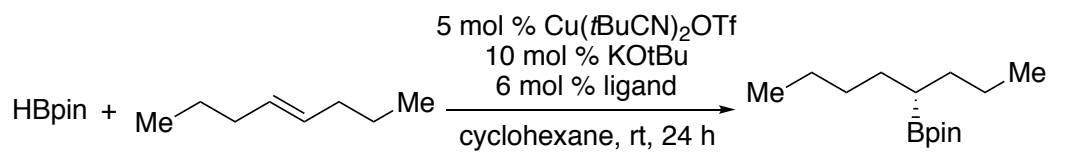

In a nitrogen-filled dry box, a 1-dram vial was charged with $\mathrm{Cu}(t \mathrm{BuCN})_{2} \mathrm{OTf}(3.8 \mathrm{mg}, 5 \mathrm{~mol} \%), \mathrm{KO} t \mathrm{Bu}(2.2 \mathrm{mg}$, $10 \mathrm{~mol} \%)$, ligand (6 mol \%) and cyclohexane $(140 \mu \mathrm{L})$. The mixture was allowed to stir at ambient temperature for 5 minutes before the addition of pinacol borane $(29.0 \mu \mathrm{L}, 0.200 \mathrm{mmol}, 1$ equiv). After stirring for another 5 minutes, trans-4-octene in neat ( $37.7 \mu \mathrm{L}, 0.240 \mathrm{mmol}, 1.2$ equiv) was added to the solution. $10.0 \mu \mathrm{L}$ of Dodecane was then added as an internal standard for GC. The vial was capped and left in the box with stirring. After 1, 12, and 24 hours of reaction, an aliquot of $10 \mu \mathrm{L}$ was removed and analyzed by GC to determine the yield of the product. The characterization of the product has been reported previously. ${ }^{1}$ 


\section{Ligand Synthesis}

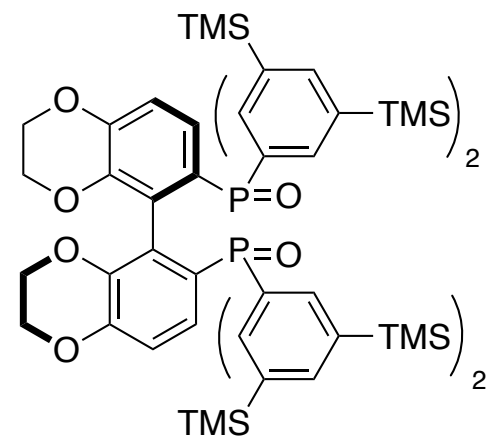

\section{(R)-TMS-SYNPHOS oxide (L12 oxide)}

A $20 \mathrm{~mL}$ vial was charged with magnesium turnings (144 mg, 12 equiv) and THF (2 ml). 3,5Bis(trimethylsilyl)bromobenzene (1.66 g, 11 equiv) was added in one portion. The vial was allowed to stir at ambient temperature for $1 \mathrm{~h}$ and placed in a heating block set to $65^{\circ} \mathrm{C}$. After $2 \mathrm{~h}$ at this temperature, the vial was cooled to room temperature, and the solution was taken up into a syringe. In a $25 \mathrm{~mL}$ round-bottom flask, $(R)$ (2,2',3,3'-tetrahydro-[5,5'-bibenzo[b][1,4]dioxine]-6,6'-diyl)bisphosphonic dichloride (252 $\mathrm{mg}, 0.500 \mathrm{mmol})$, synthesized by a known procedure, ${ }^{2}$ was dissolved in $1 \mathrm{~mL}$ THF. The flask was cooled to $0^{\circ} \mathrm{C}$ and the Grignard solution was added dropwise over the course of 20 minutes. The resulting brown solution was allowed to warm to room temperature and stir overnight. The reaction was quenched with water, and the organic material was extracted with EtOAc. The organic phase was combined and dried over $\mathrm{Na}_{2} \mathrm{SO}_{4}$. The crude material was purified by flash chromatography with $65 \%$ EtOAc in hexanes as eluent. The title compound was isolated as a pale solid (411 mg, 66\% yield).

${ }^{1} \mathrm{H}$ NMR $\left(600 \mathrm{MHz}, \mathrm{CDCl}_{3}\right) \delta 7.82(\mathrm{~d}, J=11.5,4 \mathrm{H}), 7.77(\mathrm{~d}, J=11.2,4 \mathrm{H}), 7.71(\mathrm{~s}, 2 \mathrm{H}), 7.67(\mathrm{~s}, 2 \mathrm{H}), 6.74(\mathrm{dd}, J$ $=8.1,2.6 \mathrm{~Hz}, 2 \mathrm{H}), 6.67$ (dd, $J=12.9,8.4 \mathrm{~Hz}, 2 \mathrm{H}), 3.98$ (ddd, $J=10.0,7.1,2.4 \mathrm{~Hz}, 2 \mathrm{H}), 3.72$ (ddd, $J=11.5,5.2$, $2.3 \mathrm{~Hz}, 2 \mathrm{H}), 3.50$ (ddd, $J=11.7,5.3,2.5 \mathrm{~Hz}, 2 \mathrm{H}), 3.10$ (ddd, $J=11.9,7.0,2.3 \mathrm{~Hz}, 2 \mathrm{H}), 0.22(\mathrm{~s}, 36 \mathrm{H}), 0.13$ (s, $36 \mathrm{H})$.

${ }^{31} \mathrm{P}$ NMR $\left(243 \mathrm{MHz}, \mathrm{CDCl}_{3}\right) \delta 29.3$.

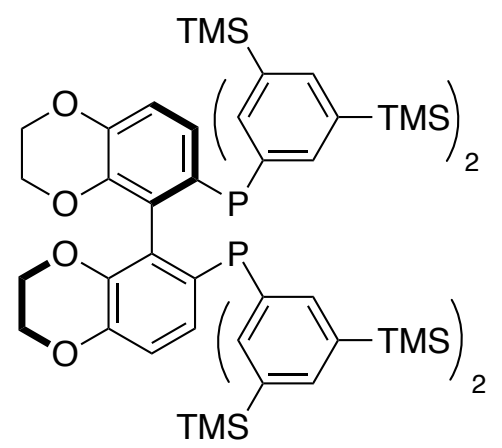

\section{(R)-TMS-SYNPHOS (L12)}


A $20 \mathrm{~mL}$ screw-capped vial was charged with (R)-TMS-SYNPHOS oxide (382 mg, $0.306 \mathrm{mmol})$. Mesitylene (2 $\mathrm{mL})$ and $\mathrm{Bu}_{3} \mathrm{~N}(1.09 \mathrm{~mL}, 15$ equiv) were added to the vial. Trichlorosilane (371 $\mu \mathrm{L}, 12$ equiv) in mesitylene (1 $\mathrm{mL}$ ) was then added dropwise to the solution. Once the evolution of gas ceased, the vial was sealed with a Teflonlined cap and placed in a $120^{\circ} \mathrm{C}$ heating block. After $22 \mathrm{~h}$, the vial was removed from the heating block and placed in an ice bath. Under a stream of nitrogen and vigorous stirring, an aqueous solution of $\mathrm{NaOH}(25 \%, 2 \mathrm{ml})$ was added to the vial dropwise. The vial was sealed and placed in an $80^{\circ} \mathrm{C}$ heating block. After 1 hour, a biphasic mixture had formed. The organic material was extracted with EtOAc. The organic solution was washed with a 2 $\mathrm{M}$ solution of $\mathrm{HCl}$ and dried over $\mathrm{Na}_{2} \mathrm{SO}_{4}$. The crude material was purified by flash chromatography with $10 \%$ EtOAc in hexanes as eluent to yield the title compound as a white solid, which was stored under nitrogen (303 $\mathrm{mg}, 81 \%$ yield).

${ }^{1} \mathrm{H} \mathrm{NMR}\left(600 \mathrm{MHz}, \mathrm{CDCl}_{3}\right) \delta 7.54(\mathrm{~s}, 2 \mathrm{H}), 7.46(\mathrm{~s}, 6 \mathrm{H}), 7.36(\mathrm{~s}, 4 \mathrm{H}), 6.78(\mathrm{~d}, J=8.4 \mathrm{~Hz}, 2 \mathrm{H}), 6.66(\mathrm{~d}, J=8.3$

$\mathrm{Hz}, 2 \mathrm{H}), 4.03$ (ddd, $J=11.4,6.7,2.3 \mathrm{~Hz}, 2 \mathrm{H}), 3.77-3.70$ (m, 2H), 3.66 (ddd, $J=11.6,5.3,2.2 \mathrm{~Hz}, 2 \mathrm{H}), 3.20-3.02$

$(\mathrm{m}, 2 \mathrm{H}), 0.19(\mathrm{~s}, 36 \mathrm{H}), 0.08(\mathrm{~s}, 36 \mathrm{H})$.

${ }^{31} \mathrm{P}$ NMR $\left(243 \mathrm{MHz}, \mathrm{CDCl}_{3}\right) \delta-15.2$.

HRMS (ESI+) Calculated for $\mathrm{C}_{64} \mathrm{H}_{97} \mathrm{O}_{4} \mathrm{P}_{2} \mathrm{Si}_{8}[\mathrm{M}+\mathrm{H}]^{+}: 1215.5011$, Found: 1215.5005 .

$[\alpha]_{\mathrm{D}}^{23}=22.7(\mathrm{c}=0.295, \mathrm{DCM})$.<smiles>CC(C)(C)c1cc(Br)cc(C(C)(C)C)c1</smiles>

A $250 \mathrm{~mL}$ round-bottom flask was charged with 1,3,5-tribromobenzene ( $3.15 \mathrm{~g}, 10.0 \mathrm{mmol})$ and diethyl ether (50 $\mathrm{ml}$ ), and a magnetic stirbar. The flask was cooled to $-78^{\circ} \mathrm{C}$. $n \mathrm{BuLi}(2.5 \mathrm{M}$ in hexanes, $4.2 \mathrm{~mL}, 1.1$ equiv) was added to the suspensions dropwise, and the mixture was stirred for an additional 30 minutes. The reaction mixture was re-cooled to $-78{ }^{\circ} \mathrm{C}$, and $\mathrm{Me}_{3} \mathrm{GeCl}(1.4 \mathrm{ml}, 1.1$ equiv) was added. The reaction was warmed to room temperature and stirred for an additional 1 hour. The reaction mixture was again cooled to $-78^{\circ} \mathrm{C}$, and $n \operatorname{BuLi}(2.5$ $\mathrm{M}$ in hexanes, $4.8 \mathrm{~mL}, 1.2$ equiv) was added dropwise. The resulting mixture was warmed to $0{ }^{\circ} \mathrm{C}$ and stirred for 1 hour. The reaction mixture was re-cooled to $-78^{\circ} \mathrm{C}$, and $\mathrm{Me}_{3} \mathrm{GeCl}(1.7 \mathrm{ml}, 1.4$ equiv) was added. After being stirred overnight at room temperature, the reaction was quenched by addition of $50 \mathrm{~mL}$ of water. The organic material was extracted with diethyl ether. The resulting solution was dried over $\mathrm{Na}_{2} \mathrm{SO}_{4}$, and filtered through Celite. The solvent was removed in vacuo. The materials were purified by flash chromatography with hexanes as eluent to afford a clear liquid, which was an inseparable mixture of the title compound ( $2.2 \mathrm{~g}$, ca. $55 \%$ yield) and tris(trimethylgermanyl)benzene in a 3.5:1 molar ratio and was used in the next step without further purification. ${ }^{1} \mathrm{H}$ NMR (600 MHz, CDCl $) \delta 7.58(\mathrm{~s}, 2 \mathrm{H}), 7.49$ (s, 1H), 0.45 (s, 18H). 


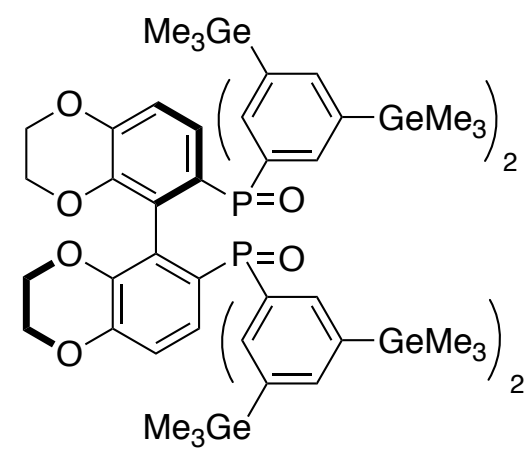

\section{(R)-TMG-SYNPHOS oxide (L13 oxide)}

A $20 \mathrm{~mL}$ vial was charged with magnesium turnings (180 $\mathrm{mg}, 15$ equiv) and THF (2 ml). 3,5Bis(trimethylgermanyl)bromobenzene ( $76 \mathrm{wt} \%, 2.57 \mathrm{~g}, 10$ equiv) was added in one portion. The vial was allowed to stir at ambient temperature for $1 \mathrm{~h}$ and placed in a heating block set to $65^{\circ} \mathrm{C}$. After $2 \mathrm{~h}$ at this temperature, the vial was cooled to room temperature, and the solution was taken up into a syringe. In a $25 \mathrm{~mL}$ round-bottom flask, $(R)$-(2,2',3,3'-tetrahydro-[5,5'-bibenzo[b][1,4]dioxine]-6,6'-diyl)bisphosphonic dichloride (252 mg, $0.500 \mathrm{mmol})$, synthesized by a known procedure, ${ }^{3}$ was dissolved in $1 \mathrm{~mL}$ THF. The flask was cooled to $0^{\circ} \mathrm{C}$ and the Grignard solution was added dropwise over the course of 20 minutes. The resulting brown solution was allowed to warm to room temperature and stir overnight. The reaction was quenched with water, and the organic material was extracted with EtOAc. The organic phase was combined and dried over $\mathrm{Na}_{2} \mathrm{SO}_{4}$. The crude material was purified by flash chromatography with $65 \%$ EtOAc in hexanes as eluent. The title compound was isolated as a pale solid (489 mg, 61\% yield).

${ }^{1} \mathrm{H}$ NMR $\left(600 \mathrm{MHz}, \mathrm{CDCl}_{3}\right) \delta 7.75(\mathrm{dd}, J=11.5,1.2 \mathrm{~Hz}, 4 \mathrm{H}), 7.70(\mathrm{dd}, J=11.1,1.2 \mathrm{~Hz}, 4 \mathrm{H}), 7.61(\mathrm{~s}, 2 \mathrm{H}), 7.56$ (s, 2H), $6.73(\mathrm{dd}, J=8.4,3.1 \mathrm{~Hz}, 2 \mathrm{H}), 6.69$ (dd, $J=12.8,8.4 \mathrm{~Hz}, 2 \mathrm{H}), 3.98(\mathrm{ddd}, J=11.3,6.9,2.4 \mathrm{~Hz}, 2 \mathrm{H}), 3.73$ (ddd, $J=11.3,5.0,2.3 \mathrm{~Hz}, 2 \mathrm{H}), 3.51(\mathrm{ddd}, J=11.5,4.9,2.4 \mathrm{~Hz}, 2 \mathrm{H}), 3.12(\mathrm{ddd}, J=11.5,6.9,2.3 \mathrm{~Hz}, 2 \mathrm{H}), 0.34$ $(\mathrm{s}, 36 \mathrm{H}), 0.25(\mathrm{~s}, 36 \mathrm{H})$.

${ }^{31} \mathrm{P}$ NMR $\left(243 \mathrm{MHz}, \mathrm{CDCl}_{3}\right) \delta 29.1$.<smiles>CCOc1cc(Pc2ccc3c(c2-c2c(Pc4cc(OC(C)=O)cc(C(C)=O)c4)ccc4c2OCCO4)OCCO3)cc(C(C)=O)c1</smiles>

\section{(R)-TMG-SYNPHOS (L13)}

A $20 \mathrm{~mL}$ screw-capped vial was charged with (R)-TMG-SYNPHOS oxide (489 mg, $0.292 \mathrm{mmol})$. Mesitylene (2 $\mathrm{mL})$ and $\mathrm{Bu}_{3} \mathrm{~N}(1.04 \mathrm{~mL}, 15$ equiv) were added to the vial. Trichlorosilane (354 $\mu \mathrm{L}, 12$ equiv) in mesitylene (4 
$\mathrm{mL}$ ) was then added dropwise to the solution. Once the evolution of gas ceased, the vial was sealed with a Teflonlined cap and placed in a $120^{\circ} \mathrm{C}$ heating block. After $22 \mathrm{~h}$, the vial was removed from the heating block and placed in an ice bath. Under a stream of nitrogen and vigorous stirring, an aqueous solution of $\mathrm{NaOH}(25 \%, 2 \mathrm{ml})$ was added to the vial dropwise. The vial was sealed and placed in an $80^{\circ} \mathrm{C}$ heating block. After 1 hour, a biphasic mixture had formed. The organic material was extracted with EtOAc. The organic solution was washed with a 2 $\mathrm{M}$ solution of $\mathrm{HCl}$ and dried over $\mathrm{Na}_{2} \mathrm{SO}_{4}$. The crude material was purified by flash chromatography with $10 \%$ EtOAc in hexanes as eluent to yield the title compound as a white solid, which was stored under nitrogen (398 mg, $83 \%$ yield).

${ }^{1} \mathrm{H}$ NMR (600 MHz, $\left.\mathrm{CDCl}_{3}\right) \delta 7.43(\mathrm{~s}, 2 \mathrm{H}), 7.40-7.36(\mathrm{~m}, 4 \mathrm{H}), 7.35$ (d, $\left.J=1.5 \mathrm{~Hz}, 2 \mathrm{H}\right), 7.29$ (dd, $J=4.2,1.9 \mathrm{~Hz}$, 4H), 6.79 (d, $J=8.4 \mathrm{~Hz}, 2 \mathrm{H}), 6.68$ (dt, $J=8.4,1.6 \mathrm{~Hz}, 2 \mathrm{H}), 4.03$ (ddd, $J=11.5,6.8,2.3 \mathrm{~Hz}, 2 \mathrm{H}), 3.74$ (ddd, $J=$ $11.3,5.2,2.2 \mathrm{~Hz}, 2 \mathrm{H}), 3.67$ (ddd, $J=11.5,5.2,2.4 \mathrm{~Hz}, 2 \mathrm{H}), 3.13(\mathrm{ddd}, J=11.6,6.8,2.2 \mathrm{~Hz}, 2 \mathrm{H}), 0.31(\mathrm{~s}, 32 \mathrm{H})$, $0.20(\mathrm{~s}, 32 \mathrm{H})$.

${ }^{31} \mathrm{P}$ NMR $\left(243 \mathrm{MHz}, \mathrm{CDCl}_{3}\right) \delta-15.0$.

HRMS (ESI+) Calculated for $\mathrm{C}_{64} \mathrm{H}_{97} \mathrm{O}_{4} \mathrm{P}_{2} \mathrm{Ge}_{8}[\mathrm{M}+\mathrm{H}]^{+}:$1572.0631, Found: 1572.0647 .

$[\alpha]_{\mathrm{D}}^{23}=18.3(\mathrm{c}=0.525, \mathrm{DCM})$.<smiles>COc1c(S(C)(=O)=O)cc(Br)cc1S(C)(=O)=O</smiles>

A $20 \mathrm{~mL}$ vial was charged with $[\operatorname{Ir}(\mathrm{COD}) \mathrm{OMe}]_{2}(10.0 \mathrm{mg}, 0.5 \mathrm{~mol} \%)$, dtbpy $(8.0 \mathrm{mg}, 1.0 \mathrm{~mol} \%), \mathrm{B}_{2} \operatorname{pin}_{2}(533$ $\mathrm{mg}, 0.7$ equiv), 2,6-bis(trimethylsilyl)anisole 5 (758 $\mathrm{mg}, 3.00 \mathrm{mmol}$ ), and $3 \mathrm{~mL}$ of THF. The vial was capped, sealed with electronical tape, and placed in a heating block set to $80{ }^{\circ} \mathrm{C}$. This procedure was repeated for two additional batches of C-H borylation. After being stirred at $80^{\circ} \mathrm{C}$ for $20 \mathrm{~h}$, the contents of the three reactions were combined and concentrated in vacuo. In a $500 \mathrm{~mL}$ round-bottom flask, the resulting crude material was dissolved in $10 \mathrm{~mL}$ of THF and $25 \mathrm{~mL}$ of methanol and $25 \mathrm{~mL}$ of water were added. The reaction mixture was heated to 80 ${ }^{\circ} \mathrm{C}$. Aliquots of the reaction were taken periodically and analyzed by GC. After 3 days of reaction, the flask was cooled to room temperature. The organic materials were extracted with diethyl ether $(50 \mathrm{~mL})$ three times. The organic layers were combined and dried over $\mathrm{Na}_{2} \mathrm{SO}_{4}$. The crude material was purified by flash chromatography with 5\% EtOAc in hexanes as eluent to yield compound 7 as a colorless liquid ( $1.18 \mathrm{~g}, 40 \%$ yield).

${ }^{1} \mathrm{H} \mathrm{NMR}\left(600 \mathrm{MHz}, \mathrm{CDCl}_{3}\right) \delta 7.55(\mathrm{~s}, 2 \mathrm{H}), 3.73(\mathrm{~s}, 3 \mathrm{H}), 0.36(\mathrm{~s}, 18 \mathrm{H})$.

${ }^{13} \mathrm{C} \mathrm{NMR}\left(151 \mathrm{MHz}, \mathrm{CDCl}_{3}\right) \delta 170.12,139.49,135.32,117.76,63.64,0.01$. 


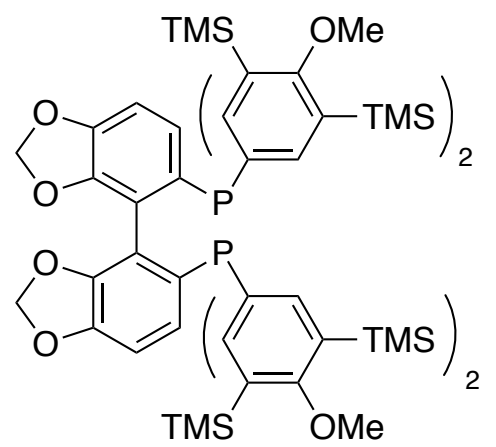

\section{DTMSM-SEGPHOS (L14)}

A $20 \mathrm{~mL}$ vial was charged with magnesium turnings ( $90 \mathrm{mg}, 15$ equiv) and THF (2 ml). 2,6-Bis(trimethylsilyl)4-bromoanisole 7 ( $750 \mathrm{mg}, 12$ equiv) was added in one portion. The vial was allowed to stir at ambient temperature for $1 \mathrm{~h}$ and placed in a heating block set to $65^{\circ} \mathrm{C}$. After $2 \mathrm{~h}$ at this temperature, the vial was cooled to room temperature, and the solution was taken up into a syringe. In a $25 \mathrm{~mL}$ round-bottom flask, $\left(2,2^{\prime}, 3,3^{\prime}\right.$-tetrahydro[4,4'-bibenzo-1,3-dioxole]-6,6'-diyl)bisphosphonic dichloride (119 mg, $0.250 \mathrm{mmol}$ ), synthesized by a known procedure, was dissolved in $1 \mathrm{~mL}$ THF. The flask was cooled to $0^{\circ} \mathrm{C}$, and the Grignard solution was added dropwise over the course of 20 minutes. The resulting brown solution was allowed to warm to room temperature and stir overnight. The reaction was quenched with water, and the organic material was extracted with EtOAc. The organic phase was combined and dried over $\mathrm{Na}_{2} \mathrm{SO}_{4}$. The crude material was purified by flash chromatography with $65 \%$ EtOAc in hexanes as eluent. The phosphine oxide was isolated, along with a small fraction of impurities. This material was used directed in the next step.

A $20 \mathrm{~mL}$ screw-capped vial was charged with the crude phosphine oxide. Mesitylene $(1 \mathrm{~mL})$ and $\mathrm{Bu} 3 \mathrm{~N}(357 \mu \mathrm{L}$, 15 equiv) were added to the vial. Trichlorosilane ( $121 \mu \mathrm{L}, 12$ equiv) in mesitylene $(0.5 \mathrm{~mL})$ was then added dropwise to the solution. Once the evolution of gas ceased, the vial was sealed with a Teflon-lined cap and placed in a $120^{\circ} \mathrm{C}$ heating block. After $22 \mathrm{~h}$, the vial was removed from the heating block and placed in an ice bath. Under a stream of nitrogen and vigorous stirring, an aqueous solution of $\mathrm{NaOH}(25 \%, 2 \mathrm{ml})$ was added to the vial dropwise. The vial was sealed and placed in an $80^{\circ} \mathrm{C}$ heating block. After 1 hour, a biphasic mixture had formed. The organic material was extracted with EtOAc. The organic solution was washed with a $2 \mathrm{M}$ solution of $\mathrm{HCl}$ and dried over $\mathrm{Na}_{2} \mathrm{SO}_{4}$. The crude material was purified by flash chromatography with $10 \%$ EtOAc in hexanes as eluent to yield the title compound as a white solid, which was stored under nitrogen ( $137 \mathrm{mg}, 42 \%$ yield).

${ }^{1} \mathrm{H}$ NMR $\left(600 \mathrm{MHz}, \mathrm{CDCl}_{3}\right) \delta$ 7.49-7.46 (m, 4H), 7.34-7.31 (m, 4H), $6.74(\mathrm{~d}, J=8.0,2 \mathrm{H}), 6.58(\mathrm{dt}, J=8.0,1.8$ $\mathrm{Hz}, 2 \mathrm{H}), 5.67(\mathrm{~d}, J=1.8 \mathrm{~Hz}, 2 \mathrm{H}), 4.83(\mathrm{~d}, J=1.9 \mathrm{~Hz}, 2 \mathrm{H}), 3.74(\mathrm{~s}, 6 \mathrm{H}), 3.70(\mathrm{~s}, 6 \mathrm{H}), 0.23(\mathrm{~s}, 36 \mathrm{H}), 0.22(\mathrm{~s}, 36 \mathrm{H})$.

${ }^{31} \mathrm{P}$ NMR $\left(142 \mathrm{MHz}, \mathrm{CDCl}_{3}\right) \delta-15.2$.

HRMS (ESI+) Calculated for $\mathrm{C}_{66} \mathrm{H}_{101} \mathrm{O}_{8} \mathrm{P}_{2} \mathrm{Si}_{8}[\mathrm{M}+\mathrm{H}]^{+}:$1307.5121, Found: 1307.5110 . 
<smiles>COc1c(Cl)cc(Cl)cc1C(C)(C)C</smiles>

A $250 \mathrm{~mL}$ round-bottom flask was charged with 2,6-dibromo-4-chloroanisole (900 $\mathrm{mg}, 3.00 \mathrm{mmol})$ and diethyl ether $(6 \mathrm{ml})$, and a magnetic stirbar. The flask was cooled to $-78^{\circ} \mathrm{C} . n \mathrm{BuLi}(2.5 \mathrm{M}$ in hexanes, $4.2 \mathrm{~mL}, 1.0$ equiv) was added to the suspensions dropwise, and the mixture was stirred for an additional 30 minutes. The reaction mixture was re-cooled to $-78{ }^{\circ} \mathrm{C}$, and $\mathrm{Me}_{3} \mathrm{GeCl}$ ( $1.4 \mathrm{ml}, 1.1$ equiv) was added. The reaction was warmed to room temperature and stirred for an additional 1 hour. The reaction mixture was again cooled to $-78{ }^{\circ} \mathrm{C}$, and $n \operatorname{BuLi}(2.5$ $\mathrm{M}$ in hexanes, $4.8 \mathrm{~mL}, 1.2$ equiv) was added dropwise. The resulting mixture was warmed to $0{ }^{\circ} \mathrm{C}$ and stirred for 1 hour. The reaction mixture was re-cooled to $-78^{\circ} \mathrm{C}$, and $\mathrm{Me}_{3} \mathrm{GeCl}(1.7 \mathrm{ml}, 1.3$ equiv) was added. After being stirred overnight at room temperature, the reaction was quenched by addition of $50 \mathrm{~mL}$ of water. The organic material was extracted with diethyl ether. The resulting solution was dried over $\mathrm{Na}_{2} \mathrm{SO}_{4}$, and filtered through celite. The solvent was removed in vacuo. The crude materials were purified by flash chromatography with hexanes as eluent to afford compound $\mathbf{1 0}$ as a clear liquid (90\% yield).

${ }^{1} \mathrm{H}$ NMR $\left(600 \mathrm{MHz}, \mathrm{CDCl}_{3}\right) \delta 7.32(\mathrm{~s}, 2 \mathrm{H}), 3.70(\mathrm{~s}, 3 \mathrm{H}), 0.48(\mathrm{~d}, J=1.6 \mathrm{~Hz}, 18 \mathrm{H})$.

${ }^{13} \mathrm{C}$ NMR $\left(151 \mathrm{MHz}, \mathrm{CDCl}_{3}\right) \delta 167.82,136.43,135.09,129.51,63.30,-0.32$.

HRMS (EI+) Calculated for $\mathrm{C}_{13} \mathrm{H}_{23} \mathrm{OClGe}_{2}[\mathrm{M}]^{+}: 377.9861$, Found: 377.9854 .

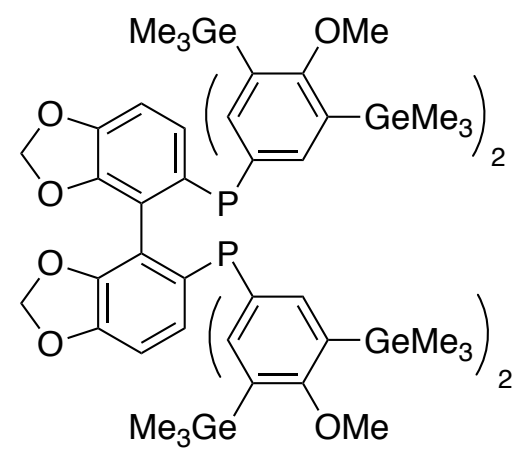

\section{DTMGM-SEGPHOS (L15)}

A $20 \mathrm{~mL}$ vial was charged with magnesium turnings (216 mg, 21 equiv) and THF (2 ml). 2,6Bis(trimethylgermanyl)-4-chloroanisole 10 (2.26 g, 14 equiv) was added in one portion. The vial was allowed to stir at ambient temperature for $1 \mathrm{~h}$ and placed in a heating block set to $65^{\circ} \mathrm{C}$. After $2 \mathrm{~h}$ at this temperature, the vial was cooled to room temperature, and the solution was taken up into a syringe. In a $25 \mathrm{~mL}$ round-bottom flask, (2,2',3,3'-tetrahydro-[4,4'-bibenzo-1,3-dioxole]-6,6'-diyl)bisphosphonic dichloride (200 $\mathrm{mg}, 0.420 \mathrm{mmol}$ ), synthesized by a known procedure, was dissolved in $1 \mathrm{~mL}$ THF. The flask was cooled to $0^{\circ} \mathrm{C}$ and the Grignard solution was added dropwise over the course of 20 minutes. The resulting brown solution was allowed to warm to room temperature and stir overnight. The reaction was quenched with water, and the organic material was extracted with EtOAc. The organic phase was combined and dried over $\mathrm{Na}_{2} \mathrm{SO}_{4}$. The crude material was purified 
by flash chromatography with $65 \%$ EtOAc in hexanes as eluent. The phosphine oxide was isolated along with a small fraction of impurities. This material was used directed in the next step.

A $20 \mathrm{~mL}$ screw-capped vial was charged with the crude phosphine oxide. Mesitylene $(3 \mathrm{~mL})$ and $\mathrm{Bu}_{3} \mathrm{~N}(856 \mu \mathrm{L}$, 15 equiv) were added to the vial. Trichlorosilane ( $290 \mu \mathrm{L}, 12$ equiv) in mesitylene ( $1 \mathrm{~mL})$ was then added dropwise to the solution. Once the evolution of gas ceased, the vial was sealed with a Teflon-lined cap and placed in a 120 ${ }^{\circ} \mathrm{C}$ heating block. After $22 \mathrm{~h}$, the vial was removed from the heating block and placed in an ice bath. Under a stream of nitrogen and vigorous stirring, an aqueous solution of $\mathrm{NaOH}(25 \%, 2 \mathrm{ml})$ was added to the vial dropwise. The vial was sealed and placed in an $80^{\circ} \mathrm{C}$ heating block. After 1 hour, a biphasic mixture had formed. The organic material was extracted with EtOAc. The organic solution was washed with a $2 \mathrm{M}$ solution of $\mathrm{HCl}$ and dried over $\mathrm{Na}_{2} \mathrm{SO}_{4}$. The crude material was purified by flash chromatography with $10 \%$ EtOAc in hexanes as eluent to yield the title compound as a white solid, which was stored under nitrogen ( $242 \mathrm{mg}, 35 \%$ yield).

${ }^{1} \mathrm{H}$ NMR $\left(600 \mathrm{MHz}, \mathrm{CDCl}_{3}\right) \delta$ 7.43-7.39 (m, 4H), 7.26-7.22 (m, 4H), 6.73 (d, J=8.0 Hz, 2H), 6.61 (dt, $J=8.0$, $1.7 \mathrm{~Hz}, 2 \mathrm{H}), 5.67$ (d, $J=1.7 \mathrm{~Hz}, 2 \mathrm{H}), 4.86(\mathrm{~d}, J=1.7 \mathrm{~Hz}, 2 \mathrm{H}), 3.71$ (s, 6H), 3.68 (s, 6H), 0.35 (s, 36H), 0.35 (s, $36 \mathrm{H})$.

${ }^{31} \mathrm{P}$ NMR $\left(142 \mathrm{MHz}, \mathrm{CDCl}_{3}\right) \delta-15.7$.

HRMS (ESI+) Calculated for $\mathrm{C}_{66} \mathrm{H}_{101} \mathrm{O}_{8} \mathrm{P}_{2} \mathrm{Ge}_{8}[\mathrm{M}+\mathrm{H}]^{+}: 1675.0660$, Found: 1675.0630 .

\section{Assignment of Absolute Configuration}

The absolute configuration of the boronic ester products was assigned by comparison of the optical rotation value of the corresponding alcohol obtained from $\mathrm{NaOH} / \mathrm{H}_{2} \mathrm{O}_{2}$ oxidation described in section II to those reported previously. We selected three different alcohols $\left(\mathbf{4 a - O H},{ }^{4-5} \mathbf{4 c - O H},{ }^{6-7} \mathbf{4 0 - O} \mathbf{O H}^{8-9}\right)$ that were prepared by the sequence of hydroboration and oxidation, and compared their optical rotation values to the literature values that were published by several different groups. All spectroscopic data of the three alcohols are consistent with previous literatures, and all optical rotation data were consistent with the following assignment of absolute configuration.

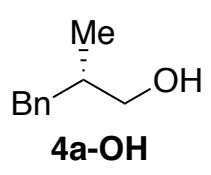

$(S)-:[\alpha]_{23}{ }^{\mathrm{D}}=-9.4\left(\mathrm{c}=0.5, \mathrm{CHCl}_{3}\right)$

lit:

$(S)-:[\alpha]_{23} \mathrm{D}=-9.9\left(\mathrm{c}=0.9, \mathrm{CHCl}_{3}\right)^{4}$

$(S)-:[\alpha]_{23} \mathrm{D}=-10.1\left(\mathrm{c}=0.8, \mathrm{CHCl}_{3}\right)^{5}$

$(R)-:[\alpha]_{23} \mathrm{D}=10.4\left(\mathrm{c}=2.3, \mathrm{CHCl}_{3}\right)^{4}$
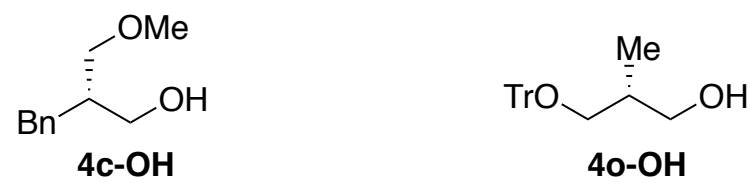

$(S)-:[\alpha]_{23}{ }^{\mathrm{D}}=-14.8\left(\mathrm{c}=0.5, \mathrm{CHCl}_{3}\right)(R)-:[\alpha]_{23}{ }^{\mathrm{D}}=22.0\left(\mathrm{c}=0.49, \mathrm{CHCl}_{3}\right)$

lit: lit:

$(S)-:[\alpha]_{25} \mathrm{D}=-18.4\left(\mathrm{c}=1.7, \mathrm{CHCl}_{3}\right)^{6}(R)-:[\alpha]_{23} \mathrm{D}=24.7\left(\mathrm{c}=0.36, \mathrm{CHCl}_{3}\right)^{8}$

$(R)-:[\alpha]_{25} \mathrm{D}=13.0(\mathrm{c}=1.0, \mathrm{MeOH})^{7}(S)-:[\alpha]_{23} \mathrm{D}=-22.2(\mathrm{c}=1.0, \mathrm{DCM})^{9}$

Figure S1. Comparison of optical rotation 
Our assignment is opposite to that reported by Yun. ${ }^{10}$ We repeated the same reaction using the conditions reported by Yun and compared the major enantiomer obtained by Yun's condition to that obtained by our condition with $(R)$-TMG-SYNPHOS as the ligand. SFC traces showed that these two major products are indeed the same enantiomer (Figure S2).
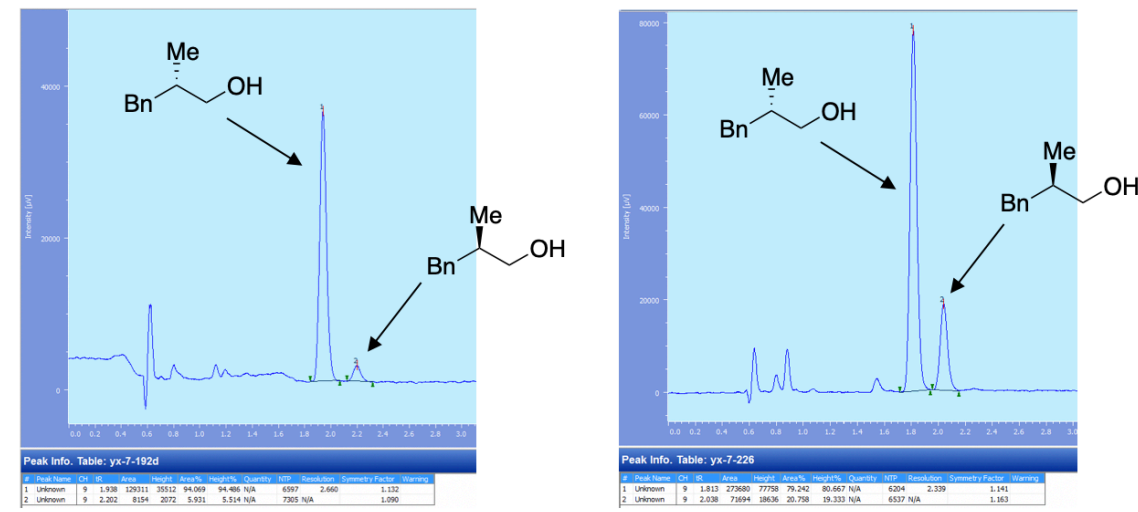

sample prepared by our condition (88\% ee with CuMes, KOtBu, $(R)$-TMGSYNPHOS, decalin)

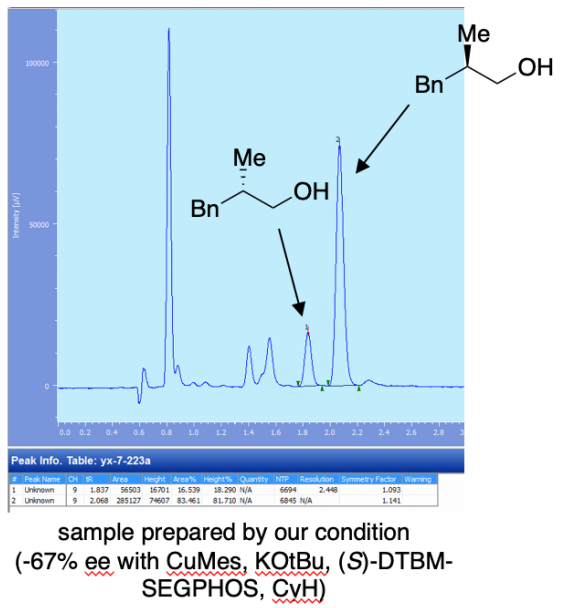

sample prepared by Yun's condition $(61 \%$ ee with $\mathrm{CuCl}, \mathrm{KOtBu},(R)$-DTBMSEGPHOS, toluene)

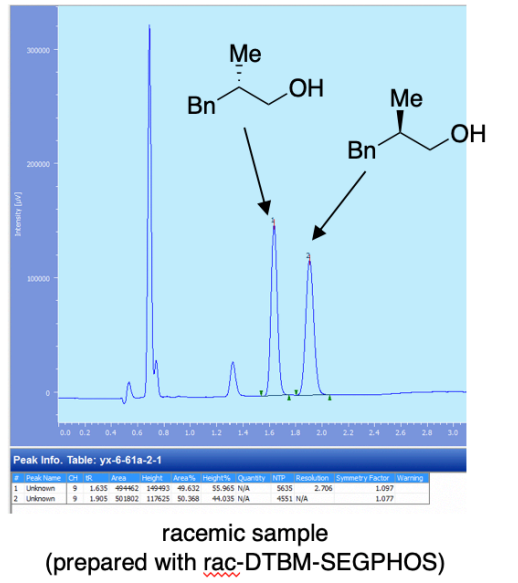

Figure S2. SFC traces of samples of $\mathbf{4 a - O H}$ obtained by several methods

In addition, our assignment is consistent with the absolute configuration of the amine products prepared by formal hydroamination of 1,1-disubstituted alkenes reported by Buchwald. ${ }^{11}$ Previous studies on the copper-catalyzed hydroboration and formal hydroamination showed that the absolute configuration of the products was set by the alkene insertion step. Figure S3 shows that the absolute configuration of the hydroboration products reported by Yun was opposite to that of the hydroamination product reported by Buchwald with the same starting alkenes and the same ligand, $(R)$-DTBM-SEGPHOS. 


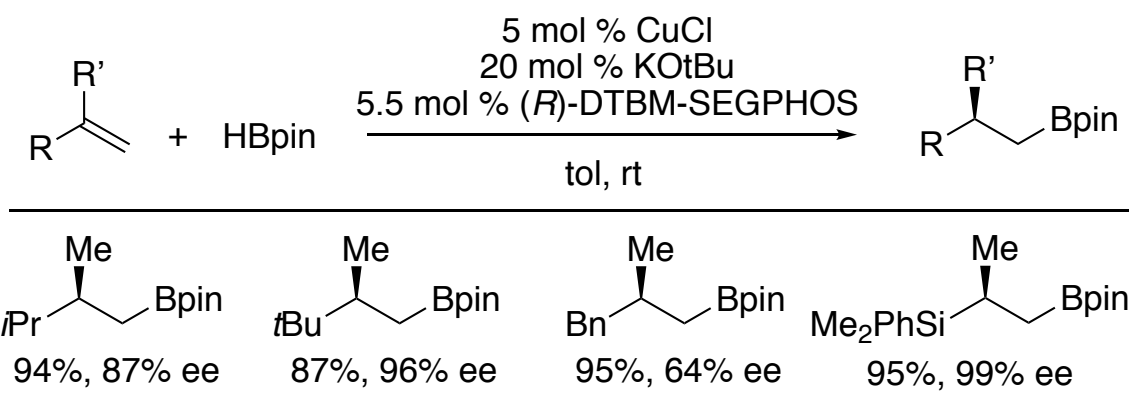
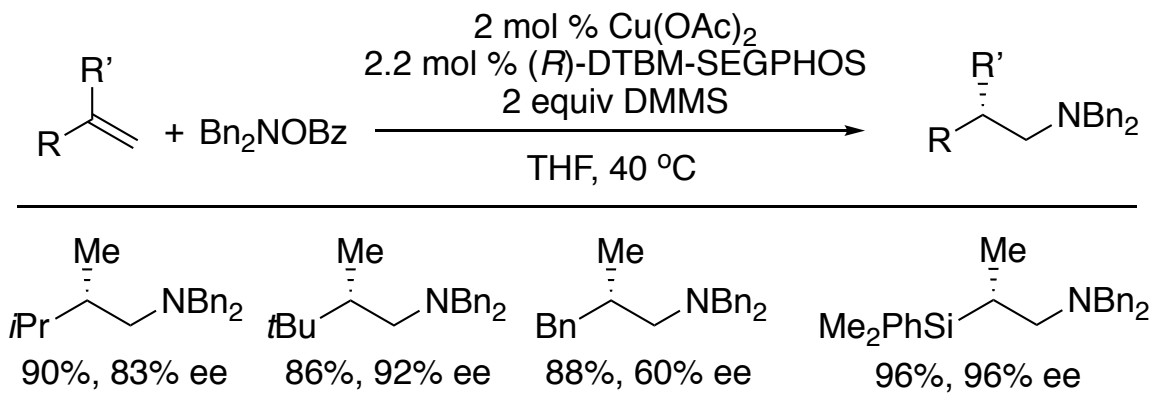

Figure S3. The stereochemical outcome of hydroboration and hydroamination of the same alkenes with the same enantiomer of DTBM-SEGPHOS as the ligand reported by Yun and Buchwald respectively

Based on the above results, we concluded that the assignment of absolute stereochemistry by Yun is incorrect.

\section{DFT Calculation}

\section{Computational methods}

Density functional theory (DFT) geometry optimizations and single point energy calculations were performed using the Gaussian 09 software package. ${ }^{12}$ Energy decomposition analysis (EDA) calculations were performed using Q-Chem 5.2. ${ }^{13}$ All calculations were performed on Pitt CRC, TACC, and XSEDE ${ }^{14}$ supercomputers. Geometries were optimized using the $\omega \mathrm{B} 97 \mathrm{X}-\mathrm{D}^{15}$ functional with a mixed basis set of SDD for $\mathrm{Cu}$ and $6-31 \mathrm{G}(\mathrm{d})$ for other atoms in the gas phase. The "ultrafine" integration grid was used in geometry optimization and vibrational frequency calculations. Vibrational frequency calculations were performed for all the stationary points to confirm if each optimized structure is a local minimum or a transition state structure. Truhlar's quasi-harmonic corrections ${ }^{16}$ were applied for entropy calculations with a frequency cut-off of $100 \mathrm{~cm}^{-1}$ using the GoodVibes ${ }^{17}$ program. Single point energies were calculated using $\omega$ B97X-D and def2-TZVP basis set in cyclohexane using the SMD solvation model. ${ }^{18}$ The second-generation ALMO-EDA calculations were performed in cyclohexane using $\omega$ B97X-D and def2-TZVP basis set in Q-Chem 5.2. The solvation energy term was included in the reported electrostatic interaction energies $\left(\Delta E_{\text {elstat }}\right)$.

\section{Distortion interaction analysis and EDA results}




\begin{tabular}{|c|c|c|c|c|c|c|c|c|}
\hline \multicolumn{4}{|c|}{$\Delta E^{\ddagger}=\Delta E_{\text {dist }}+\Delta E_{\text {int-bond }}+\Delta E_{\text {int-space }}$} & \multicolumn{5}{|c|}{$\begin{array}{l}\text { TS-B } \\
=\Delta E_{\text {elstat }}+\Delta E_{\text {Pauli }}+\Delta E_{\text {orb }}+\Delta E_{\text {disp }}\end{array}$} \\
\hline & $\Delta E^{\ddagger}$ & $\Delta E_{\text {dist }}$ & $\Delta E_{\text {int-bond }}$ & $\Delta E_{\text {int-space }}$ & $\Delta E_{\text {elstat }}$ & $\Delta E_{\text {Pauli }}$ & $\Delta E_{\text {orb }}$ & $\Delta E_{\mathrm{disp}}$ \\
\hline TS-1A & -0.7 & 32.6 & -24.4 & -9.0 & -2.9 & 22.1 & -4.0 & -24.2 \\
\hline TS-1B & 0.5 & 32.9 & -24.9 & -7.5 & -2.0 & 19.5 & -3.5 & -21.5 \\
\hline$\Delta \Delta E^{\ddagger}(\mathrm{DTB})$ & 1.2 & 0.3 & -0.5 & 1.5 & 0.9 & -2.6 & 0.5 & 2.7 \\
\hline TS-2A & -1.1 & 34.0 & -24.4 & -10.7 & -2.8 & 22.1 & -4.1 & -25.9 \\
\hline TS-2B & 0.8 & 31.2 & -24.4 & -6.0 & -1.7 & 18.1 & -3.4 & -19.0 \\
\hline$\Delta \Delta E^{\ddagger}(\mathrm{TMS})$ & 1.9 & -2.8 & 0 & 4.7 & 1.1 & -4.0 & 0.7 & 6.9 \\
\hline TS-3A & -1.3 & 34.4 & -24.2 & -11.5 & -3.1 & 22.8 & -4.3 & -26.9 \\
\hline TS-3B & 1.3 & 32.4 & -24.1 & -7.0 & -2.0 & 17.8 & -3.2 & -19.6 \\
\hline$\Delta \Delta E^{\ddagger}(\mathrm{TMG})$ & 2.6 & -2.0 & 0.1 & 4.5 & 1.1 & -5.0 & 1.1 & 7.3 \\
\hline
\end{tabular}

Table S1. Summary of distortion interaction analysis and energy decomposition analysis (EDA) on hydrocupration transition states. All energies are in $\mathrm{kcal} / \mathrm{mol}$.

Computational results of distortion interaction analysis and energy decomposition analysis (EDA) are summarized in Table S1. The computed activation energy $\left(\Delta E^{\ddagger}\right)$ was separated into the following terms: distortion energy ( $\left.\Delta E_{\text {dist }}\right)$, through-bond interaction $\left(\Delta E_{\text {int-bond }}\right)$, and through-space interaction between the ligand and the alkene substrate $\left(\Delta E_{\text {int-space }}\right)$. Here, $\Delta E_{\text {dist }}$ is computed from the sum of the distortion energies of the LCuH catalyst and the alkene substrate with respect to the ground state. The through-space interaction energy was calculated from the interaction between the ligand and the alkene substrate in a hypothetical supramolecular complex that is formed by removing the $\mathrm{CuH}$ moiety from the transition state geometry. The rest of the catalyst-substrate interaction energy is then defined as the through-bond interaction. The same procedure to separate activation energies into distortion, through-bond and through-space interactions was used in our previous publications. ${ }^{19}$

Using the second-generation AMLO-EDA, the through-space interaction energy ( $\Delta E_{\text {int-bond }}$ ) is dissected further to energies of electrostatics $\left(\Delta E_{\text {elstat }}\right)$, Pauli repulsion $\left(\Delta E_{\text {Pauli }}\right)$, orbital interaction $\left(\Delta E_{\text {orb }}\right)$, and dispersion $\left(\Delta E_{\text {disp }}\right)$. The contribution of each term to the activation energy is listed here. These results suggested that ligand-substrate 
dispersion interaction is the dominant factor that promotes the activity of $\mathrm{LCuH}$ catalysts with bulkier ligands (TMS-SEGPHOS and TMG-SEGPHOS) in the hydrocupration step. Furthermore, dispersion is also the major factor that leads to the higher enantioselectivity of reactions that use bulkier ligands. 


\title{
Cartesian coordinates $(\AA)$ and energies of optimized structures
}

\author{
2-Methyl-1-pentene \\ wB97XD SCF energy: $\quad-235.77763662$ a.u. \\ wB97XD enthalpy: $\quad-235.601268$ a.u. \\ wB97XD free energy: $\quad-235.642228$ a.u. \\ wB97XD SCF energy in solution: $\quad-235.86816877$ a.u. \\ wB97XD enthalpy in solution: $\quad-235.691800$ a.u. \\ wB97XD free energy in solution: $\quad-235.732760$ a.u.
}

wB97XD free energy in solution after quasi-harmonic correction: -235.732064 a.u.

Cartesian coordinates

\begin{tabular}{|c|c|c|c|}
\hline ATOI & M & Y & Z \\
\hline $\mathrm{C}$ & 1.161120 & -0.138978 & 0.098132 \\
\hline $\mathrm{C}$ & 1.955613 & -1.161290 & -0.219757 \\
\hline $\mathrm{H}$ & 1.605257 & -2.189622 & -0.177389 \\
\hline $\mathrm{C}$ & -0.270196 & -0.353032 & 0.531376 \\
\hline $\mathrm{H}$ & -0.421991 & 0.105173 & 1.520342 \\
\hline $\mathrm{H}$ & -0.458695 & -1.427013 & 0.651572 \\
\hline $\mathrm{H}$ & 2.985560 & -1.009388 & -0.532976 \\
\hline $\mathrm{C}$ & 1.641494 & 1.288447 & 0.040788 \\
\hline $\mathrm{H}$ & 1.470812 & 1.795723 & 0.998897 \\
\hline $\mathrm{H}$ & 2.708470 & 1.344938 & -0.192375 \\
\hline $\mathrm{H}$ & 1.099690 & 1.861140 & -0.721743 \\
\hline $\mathrm{C}$ & -1.307364 & 0.228995 & -0.440137 \\
\hline $\mathrm{H}$ & -1.131622 & -0.188988 & -1.439211 \\
\hline $\mathrm{H}$ & -1.168899 & 1.313723 & -0.526778 \\
\hline $\mathrm{C}$ & -2.740443 & -0.062305 & 0.000890 \\
\hline $\mathrm{H}$ & -3.467045 & 0.360883 & -0.700228 \\
\hline $\mathrm{H}$ & -2.921647 & -1.141595 & 0.061463 \\
\hline $\mathrm{H}$ & -2.941237 & 0.363999 & 0.990676 \\
\hline
\end{tabular}




\section{DTB-segphosCuH}

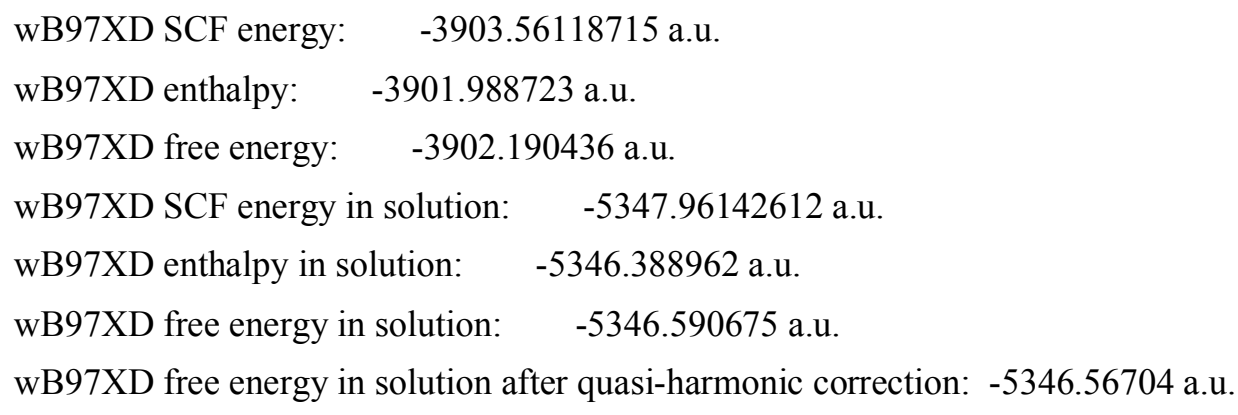

Cartesian coordinates
$\begin{array}{llll}\text { ATOM } & \mathrm{X} & \mathrm{Y} & \mathrm{Z}\end{array}$
$\begin{array}{llll}\text { C } & -3.319953 & 0.493236 & -1.174081\end{array}$
C $\quad-3.334724 \quad 1.433486 \quad-2.208625$
H $\quad-2.392635 \quad 1.687653 \quad-2.684081$
$\begin{array}{llll}\text { C } & -4.529090 & 2.012658 & -2.627991\end{array}$
$\begin{array}{lllll}\text { C } & -5.711775 & 1.599507 & -1.997998\end{array}$
$\begin{array}{lllll}\text { C } & -5.732947 & 0.641856 & -0.984307\end{array}$
$\begin{array}{lllll}\text { C } & -4.510513 & 0.099916 & -0.576538\end{array}$
$\begin{array}{llll}\mathrm{H} & -4.485918 & -0.639912 & 0.216893\end{array}$
$\begin{array}{llll}\text { C } & -4.581413 & 3.075703 & -3.731886\end{array}$
$\begin{array}{lllll}\text { C } & -3.195269 & 3.361754 & -4.328269\end{array}$
$\mathrm{H} \quad-2.503223 \quad 3.759670 \quad-3.577568$
$\mathrm{H} \quad-3.287286 \quad 4.112318 \quad-5.121189$
H $\quad-2.745017 \quad 2.464926-4.767323$
$\begin{array}{llll}\text { C } & -5.130379 & 4.386954 & -3.137435\end{array}$
$\mathrm{H} \quad-6.140103 \quad 4.259532-2.732355$
$\mathrm{H} \quad-5.174129 \quad 5.165404 \quad-3.908395$
$\mathrm{H} \quad-4.484284 \quad 4.743497 \quad-2.326941$
$\begin{array}{llll}\text { C } & -5.503907 & 2.594947 & -4.867907\end{array}$
$\mathrm{H} \quad-5.131743 \quad 1.659090 \quad-5.298386$
$\mathrm{H} \quad-5.545747 \quad 3.346362 \quad-5.665181$
$\mathrm{H} \quad-6.527783 \quad 2.422867 \quad-4.519488$
$\begin{array}{lllll}\text { C } & -7.021274 & 0.174695 & -0.295371\end{array}$
$\begin{array}{llll}\text { C } & -8.272400 & 0.849657 & -0.873459\end{array}$
$\mathrm{H} \quad-9.163398 \quad 0.478144 \quad-0.355518$
H $\quad-8.393729 \quad 0.631688-1.940480$
$\mathrm{H} \quad-8.244280 \quad 1.937489 \quad-0.743441$ 


$$
\begin{aligned}
& \begin{array}{llll}
\text { C } & -7.168267 & -1.349102 & -0.472590
\end{array} \\
& \mathrm{H} \quad-8.084884 \quad-1.7014110 .015350 \\
& \mathrm{H} \quad-6.325131-1.893300 \quad-0.033805 \\
& \mathrm{H} \quad-7.220258-1.614102-1.534128 \\
& \begin{array}{llll}
\text { C } & -6.941095 & 0.510231 & 1.206719
\end{array} \\
& \text { H } \quad-6.827608 \quad 1.589321 \quad 1.359041 \\
& \text { H } \quad-6.092703 \quad 0.012999 \quad 1.689015 \\
& \mathrm{H} \quad-7.854586 \quad 0.185424 \quad 1.718946 \\
& \text { C } \quad-1.873203 \quad-1.817456-0.104951 \\
& \begin{array}{llll}
\text { C } & -1.252255 & -2.761871 & -0.912891
\end{array} \\
& \text { H } \quad-0.719079 \quad-2.422854-1.798805 \\
& \text { C } \quad-1.284095 \quad-4.123235-0.597194 \\
& \begin{array}{llll}
\text { C } & -1.999325 & -4.502045 & 0.534441
\end{array} \\
& \begin{array}{llll}
\text { C } & -2.640954 & -3.576212 & 1.373024
\end{array} \\
& \begin{array}{llll}
\text { C } & -2.549447 & -2.226242 & 1.049286
\end{array} \\
& \mathrm{H} \quad-2.972070 \quad-1.471771 \quad 1.704212 \\
& \begin{array}{llll}
\text { C } & -0.517975 & -5.107963 & -1.487053
\end{array} \\
& \begin{array}{llll}
\text { C } & -1.054086 & -5.022422 & -2.928819
\end{array} \\
& \mathrm{H} \quad-0.514092 \quad-5.725186 \quad-3.574415 \\
& \mathrm{H} \quad-0.930811 \quad-4.020116 \quad-3.351503 \\
& \mathrm{H} \quad-2.119788 \quad-5.274607 \quad-2.963457 \\
& \text { C } \quad 0.976976 \quad-4.729628 \quad-1.472722 \\
& \text { H } \quad 1.548251 \quad-5.411730 \quad-2.113949 \\
& \text { H } \quad 1.380867 \quad-4.787920 \quad-0.456125 \\
& \mathrm{H} \quad 1.142992 \quad-3.709814-1.837003 \\
& \text { C } \quad-0.653690 \quad-6.557214-1.002163 \\
& \text { H } \quad-1.697193 \quad-6.892519-1.013396 \\
& \mathrm{H} \quad-0.259850 \quad-6.684085 \quad 0.012830 \\
& \text { H } \quad-0.085935 \quad-7.220880-1.663421 \\
& \begin{array}{llll}
\text { C } & -3.432055 & -4.078263 & 2.586353
\end{array} \\
& \begin{array}{llll}
\text { C } & -2.584555 & -5.081967 & 3.392637
\end{array} \\
& \mathrm{H} \quad-1.595001 \quad-4.673383 \quad 3.619277 \\
& \mathrm{H} \quad-2.431347 \quad-6.018730 \quad 2.847276 \\
& \mathrm{H} \quad-3.088607 \quad-5.334933 \quad 4.332902 \\
& \begin{array}{llll}
\text { C } & -3.845989 & -2.928873 & 3.516986
\end{array} \\
& \mathrm{H} \quad-2.978842 \quad-2.349140 \quad 3.850395 \\
& \mathrm{H} \quad-4.355744 \quad-3.332720 \quad 4.398854
\end{aligned}
$$




\begin{tabular}{|c|c|c|c|}
\hline & -4.544748 & -2.241617 & 5923 \\
\hline $\mathrm{C}$ & -4.707289 & -4.781942 & 2.083281 \\
\hline & -5.290733 & -5.169169 & 2.927551 \\
\hline & -4.464087 & -5.622546 & 1.424376 \\
\hline & -5.339171 & -4.085937 & 1.519954 \\
\hline C & 3029 & 48 & 48 \\
\hline C & -2.180909 & 2.006387 & 1.182087 \\
\hline & -2.949112 & 2.291847 & 0.472617 \\
\hline & -1.993375 & 2.821298 & 2.306824 \\
\hline & -2.589819 & 3.711533 & 2.469649 \\
\hline C & -1.028621 & 2.420770 & 3.197667 \\
\hline $\mathrm{C}$ & 0.166472 & 2.019064 & 5.006224 \\
\hline & -0.445829 & 1.463305 & 5.731133 \\
\hline & 1.021171 & 2.498904 & 5.484761 \\
\hline C & -0.270859 & 1.281558 & 2.974502 \\
\hline $\mathrm{C}$ & -0.416489 & 0.470372 & 1.867610 \\
\hline & 0.441283 & -0.74 & 1.801686 \\
\hline & 0.288109 & -1.675170 & 2.811036 \\
\hline & -0.142671 & -2.624721 & 4.752147 \\
\hline $\mathrm{H}$ & 0.490926 & -2.157489 & 5.520250 \\
\hline $\mathrm{H}$ & -0.998013 & -3.137864 & 5.192884 \\
\hline C & 1.031391 & -2.841958 & 2.901413 \\
\hline $\mathrm{C}$ & 1.991068 & -3.150910 & 1.968854 \\
\hline $\mathrm{H}$ & 2.574809 & -4.062248 & 2.027247 \\
\hline $\mathrm{C}$ & 2.190938 & -2.213919 & 0.946264 \\
\hline $\mathrm{H}$ & 2.956242 & -2.423245 & 0.207031 \\
\hline $\mathrm{C}$ & 1.458078 & -1.028110 & 0.849524 \\
\hline $\mathrm{C}$ & 3.403977 & -0.381173 & -1.160197 \\
\hline $\mathrm{C}$ & 4.553492 & -0.070650 & -0.435977 \\
\hline $\mathrm{H}$ & 4.463756 & 0.497608 & 0.483470 \\
\hline $\mathrm{C}$ & 5.811198 & -0.474500 & -0.878092 \\
\hline $\mathrm{C}$ & 5.882156 & -1.217037 & -2.063323 \\
\hline C & 4.749830 & -1.545933 & -2.811975 \\
\hline $\mathrm{C}$ & 3.508255 & -1.104558 & -2.345343 \\
\hline $\mathrm{H}$ & 2.599754 & -1.305594 & -2.9087 \\
\hline $\mathrm{C}$ & 7.047375 & -0.099928 & -0.0497 \\
\hline & 7.124507 & 1.433676 & 0.083612 \\
\hline
\end{tabular}




\begin{tabular}{|c|c|c|c|}
\hline & 347 & 289 & 0.6 \\
\hline & 6.238226 & 1.844100 & 0.579588 \\
\hline & 7.203970 & 1.906344 & -0.901330 \\
\hline & 6.926805 & -0.729913 & 1.351536 \\
\hline & 7.801639 & -0.474251 & 1.961272 \\
\hline & 6.863670 & -1.821623 & 1.283099 \\
\hline & 6.035306 & -0.375784 & 1.880157 \\
\hline & 8.352934 & -0.592857 & -0.688495 \\
\hline & 8.503965 & 3242 & 5142 \\
\hline & 8.376176 & -1.684982 & -0.775805 \\
\hline & 9.203018 & -0.293288 & -0.065695 \\
\hline & 4.810913 & -2.355407 & -4.112733 \\
\hline & 6.240440 & -2.786532 & -4.467336 \\
\hline & 6.680029 & -3.420533 & -3.688513 \\
\hline & 6.898197 & -1.923994 & -4.623794 \\
\hline & 6.228596 & -3.364736 & -5.397687 \\
\hline & 4.259286 & -1.496860 & -5.267657 \\
\hline & 4.858963 & -0.588891 & -5.395939 \\
\hline & 3.222733 & -1.192691 & -5.090478 \\
\hline & 4.288453 & -2.062604 & -6.206604 \\
\hline & 3.947167 & -3.623217 & -3.95 \\
\hline & 3.992317 & -4.224779 & -4.875372 \\
\hline & 2.896388 & -3.378382 & -3.775199 \\
\hline & 4.302293 & -4.240003 & -3.126085 \\
\hline & 1.820668 & 1.751613 & 0.052910 \\
\hline & 2.486455 & 2.098489 & 1.232944 \\
\hline & 2.936830 & 1.314058 & 1.831159 \\
\hline & 2.532387 & 3.422574 & 1.656158 \\
\hline & 1.855036 & 4.384917 & 0.889840 \\
\hline & 1.144398 & 4.065571 & -0.262912 \\
\hline & 1.157022 & 2.730010 & -0.677031 \\
\hline & 0.624173 & 2.437220 & -1.579234 \\
\hline & 3.312037 & 3.860464 & 2.901442 \\
\hline & 4.538774 & 4.677042 & 2.451098 \\
\hline & 5.113096 & 5.017570 & 3.321291 \\
\hline & 4.240640 & 5.559825 & 1.875198 \\
\hline & 5.198856 & 4.071886 & 1.819476 \\
\hline
\end{tabular}




$\begin{array}{lrrr}\mathrm{C} & 2.421087 & 4.738125 & 3.801779 \\ \mathrm{H} & 1.469914 & 4.243822 & 4.022088 \\ \mathrm{H} & 2.186763 & 5.698839 & 3.332008 \\ \mathrm{H} & 2.934495 & 4.956346 & 4.745768 \\ \mathrm{C} & 3.803804 & 2.659640 & 3.722742 \\ \mathrm{H} & 4.528845 & 2.055984 & 3.164084 \\ \mathrm{H} & 2.975223 & 2.007045 & 4.017835 \\ \mathrm{H} & 4.307355 & 3.013625 & 4.629221 \\ \mathrm{C} & 0.332384 & 5.087336 & -1.067501 \\ \mathrm{C} & -1.157746 & 4.698850 & -0.993453 \\ \mathrm{H} & -1.511722 & 4.716280 & 0.042906 \\ \mathrm{H} & -1.334321 & 3.690892 & -1.384856 \\ \mathrm{H} & -1.763858 & 5.400525 & -1.580089 \\ \mathrm{C} & 0.790121 & 5.076929 & -2.538427 \\ \mathrm{H} & 0.217554 & 5.812548 & -3.115708 \\ \mathrm{H} & 0.641352 & 4.099684 & -3.008729 \\ \mathrm{H} & 1.852894 & 5.330729 & -2.618190 \\ \mathrm{C} & 0.487288 & 6.513382 & -0.522683 \\ \mathrm{H} & -0.101939 & 7.206285 & -1.133240 \\ \mathrm{H} & 1.530773 & 6.847253 & -0.554353 \\ \mathrm{H} & 0.128222 & 6.595905 & 0.509486 \\ \mathrm{O} & -0.636257 & 3.005802 & 4.371508 \\ \mathrm{O} & 0.626189 & 1.132426 & 3.999697 \\ \mathrm{O} & -0.601885 & -1.630165 & 3.852031 \\ \mathrm{O} & 0.632615 & -3.550789 & 4.002942 \\ \mathrm{P} & -1.676510 & -0.078373 & -0.624421 \\ \mathrm{P} & 1.716354 & 0.054708 & -0.615344 \\ \mathrm{Cu} & 0.034475 & -0.028560 & -2.176747 \\ \mathrm{H} & 0.016823 & -0.101124 & -3.732323 \\ \mathrm{H} & -2.057547 & -5.553878 & 0.790838 \\ \mathrm{H} & 6.852579 & -1.543951 & -2.414376 \\ & -6.647468 & 2.042503 & -2.321812 \\ \mathrm{H} & 1.882079 & 5.416670 & 1.221979\end{array}$




\section{TMS-segphosCuH}

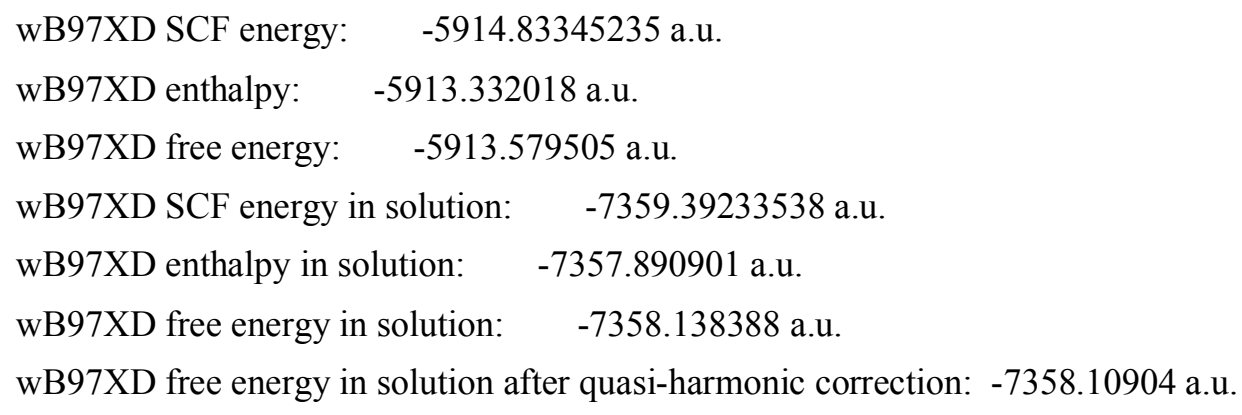

Cartesian coordinates

$\begin{array}{lrcc}\text { ATOM } & \text { X } & \text { Y Z } \\ \text { C } & 3.323379 & 0.499860 & 1.139113 \\ \text { C } & 3.333775 & 1.519071 & 2.093779 \\ \text { H } & 2.384201 & 1.834521 & 2.523463 \\ \text { C } & 4.527647 & 2.120896 & 2.508641 \\ \text { C } & 5.719751 & 1.636501 & 1.954740 \\ \text { C } & 5.754582 & 0.589541 & 1.021640 \\ \text { C } & 4.533630 & 0.039320 & 0.619933 \\ \text { H } & 4.523362 & -0.769523 & -0.104424 \\ \text { C } & 2.764519 & 3.891124 & 4.304325 \\ \text { H } & 2.148920 & 4.240197 & 3.467873 \\ \text { H } & 2.751057 & 4.673533 & 5.072088 \\ \text { H } & 2.281195 & 3.002103 & 4.725741 \\ \text { C } & 5.275357 & 5.055514 & 2.929295 \\ \text { H } & 6.303851 & 4.865380 & 2.600687 \\ \text { H } & 5.296967 & 5.911668 & 3.613677 \\ \text { H } & 4.692762 & 5.341885 & 2.046389 \\ \text { C } & 5.588209 & 3.040556 & 5.238296 \\ \text { H } & 5.167976 & 2.163832 & 5.743264 \\ \text { H } & 5.649927 & 3.854667 & 5.969881 \\ \text { H } & 6.610404 & 2.789977 & 4.931458 \\ \text { C } & 8.218950 & 1.315301 & -0.665069 \\ \text { H } & 9.184483 & 0.984174 & -1.064898 \\ \text { H } & 8.401629 & 2.196920 & -0.039724 \\ \text { H } & 7.594190 & 1.630476 & -1.508260 \\ \text { C } & 8.498322 & -0.583479 & 1.744772 \\ \text { H } & 9.467242 & -0.941085 & 1.377348\end{array}$




\begin{tabular}{|c|c|c|c|}
\hline & 8.037820 & -1.390099 & 2.325769 \\
\hline & 8.689460 & 0.250614 & 2.429891 \\
\hline & 7.018614 & -1.529875 & -0.796628 \\
\hline & 6.398785 & -1.242910 & -1.654626 \\
\hline & 6.490383 & -2.320140 & -0.250136 \\
\hline & 7.948112 & -1.958426 & -1.188525 \\
\hline & 1.894323 & -1.842221 & 0.100907 \\
\hline & 1.230500 & -2.790840 & 0.878327 \\
\hline & 0.679433 & -2.449355 & 1.755243 \\
\hline & 1.231643 & -4.150096 & 0.544935 \\
\hline 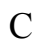 & 1.956734 & -4.532379 & -0.587389 \\
\hline & 2.654470 & -3.613204 & -1.388362 \\
\hline & 2.591057 & -2.262420 & -1.036164 \\
\hline & 3.056980 & -1.515700 & -1.676392 \\
\hline & 0.976849 & -5.356720 & 3.348132 \\
\hline & 0.407114 & -6.012912 & 4.016515 \\
\hline & 0.966886 & -4.349568 & 3.781373 \\
\hline & 2.016122 & -5.703516 & 3.336787 \\
\hline & -1.543017 & -4.736113 & 1.707514 \\
\hline & -2.118301 & -5.312395 & 2.441437 \\
\hline & -2.041029 & -4.826110 & 0.736287 \\
\hline & -1.589115 & -3.681358 & 2.005090 \\
\hline & 0.299146 & -7.065888 & 0.852380 \\
\hline & 1.323336 & -7.454306 & 0.812136 \\
\hline & -0.101007 & -7.063853 & -0.168193 \\
\hline & -0.298236 & -7.770253 & 1.442476 \\
\hline & 2.639586 & -5.556592 & -3.747385 \\
\hline & 1.572111 & -5.315610 & -3.798457 \\
\hline & 2.729605 & -6.500574 & -3.196747 \\
\hline & 3.005962 & -5.739105 & -4.764488 \\
\hline 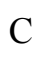 & 3.947069 & -2.730152 & -4.031245 \\
\hline & 3.040714 & -2.139543 & -4.200365 \\
\hline & 4.334426 & -3.063857 & -5.000901 \\
\hline & 4.697644 & -2.059812 & -3.595183 \\
\hline & 5.286951 & -4.905690 & -2.335508 \\
\hline & 5.849122 & -5.306011 & -3.187715 \\
\hline & 5.148325 & -5.718234 & -1.613179 \\
\hline
\end{tabular}




\begin{tabular}{|c|c|c|c|}
\hline & 5.903482 & -4.135029 & -1.8 \\
\hline C & 1.438730 & 0.787821 & -1.001957 \\
\hline & 2.177068 & 1.941930 & -1.270432 \\
\hline & 2.951763 & 2.249132 & -0.577394 \\
\hline & 1.970831 & 2.729569 & -2.411605 \\
\hline & 2.555814 & 3.622389 & -2.599436 \\
\hline & 1.001863 & 2.300166 & -3.283698 \\
\hline & -0.206318 & 1.850358 & -5.072719 \\
\hline & 0.405160 & 1.294238 & -5.797967 \\
\hline & -1.075684 & 2.308192 & -5.545884 \\
\hline & 0.263363 & 1.153258 & -3.032521 \\
\hline & 0.419885 & 0.375127 & -1.904714 \\
\hline & -0.430219 & -0.843498 & -1.789756 \\
\hline & -0.255703 & -1.826945 & -2.741745 \\
\hline 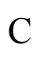 & 0.225075 & -2.902284 & -4.605676 \\
\hline U & -0.407722 & -2.512677 & -5.416493 \\
\hline & 1.102579 & -3.420370 & -4.993186 \\
\hline & -0.967910 & -3.017108 & -2.757187 \\
\hline & -1.931348 & -3.284432 & -1.815925 \\
\hline U & -2.492673 & -4.211651 & -1.818588 \\
\hline 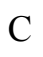 & -2.162351 & -2.286778 & -0.859020 \\
\hline$\Pi$ & -2.930667 & -2.463638 & -0.114465 \\
\hline $\mathrm{C}$ & -1.450864 & -1.085239 & -0.830266 \\
\hline C & -3.410431 & -0.333096 & 1.140160 \\
\hline$C$ & -4.559187 & -0.121274 & 0.371003 \\
\hline $\mathrm{H}$ & -4.460212 & 0.330258 & -0.611257 \\
\hline $\mathrm{C}$ & -5.825048 & -0.472235 & 0.840121 \\
\hline & -5.907047 & -1.064042 & 2.113245 \\
\hline 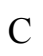 & -4.784649 & -1.293295 & 2.913249 \\
\hline $\mathrm{C}$ & -3.534596 & -0.906833 & 2.403897 \\
\hline H & -2.632048 & -1.036236 & 3.001618 \\
\hline & -8.540466 & 0.957063 & 0.778034 \\
\hline$n$ & -9.461842 & 1.149935 & 0.216236 \\
\hline $\mathrm{H}$ & -8.074323 & 1.922064 & 1.005782 \\
\hline 11 & -8.821824 & 0.492172 & 1.730043 \\
\hline 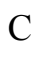 & -6.847781 & 0.712809 & -1.794699 \\
\hline & -7.724045 & 0.960776 & -2.404275 \\
\hline
\end{tabular}




$$
\begin{aligned}
& \begin{array}{llll}
\mathrm{H} & -6.193530 & 0.073108 & -2.399048
\end{array} \\
& \text { H } \quad-6.310179 \quad 1.646332-1.588683 \\
& \begin{array}{llll}
\text { C } & -8.211867 & -1.783473 & -0.589389
\end{array} \\
& \mathrm{H} \quad-8.483296 \quad-2.317612 \quad 0.328574 \\
& \mathrm{H} \quad-7.553276-2.437597 \quad-1.171612 \\
& \text { H } \quad-9.129959-1.626822 \quad-1.167613 \\
& \text { C } \quad-6.661831 \quad-2.480083 \quad 5.044395 \\
& \mathrm{H} \quad-7.094310 \quad-3.185374 \quad 4.325240 \\
& \mathrm{H} \quad-7.286341 \quad-1.579282 \quad 5.051983 \\
& \mathrm{H} \quad-6.730245 \quad-2.937500 \quad 6.038067 \\
& \begin{array}{llll}
\text { C } & -4.153517 & -0.861776 & 5.876222
\end{array} \\
& \mathrm{H} \quad \begin{array}{llll}
4.746876 & 0.058483 & 5.917419
\end{array} \\
& \mathrm{H} \quad-3.127900 \quad-0.583787 \quad 5.605981 \\
& \mathrm{H} \quad-4.129198 \quad-1.294762 \quad 6.883134 \\
& \begin{array}{llll}
\text { C } & -3.833275 & -3.651117 & 4.616419
\end{array} \\
& \mathrm{H} \quad-3.853988-4.145721 \quad 5.594617 \\
& \mathrm{H} \quad-2.786806 \quad-3.427478 \quad 4.378748 \\
& \mathrm{H} \quad-4.200360 \quad-4.362161 \quad 3.867643 \\
& \begin{array}{lllll}
\text { C } & -1.830789 & 1.725719 & -0.203202
\end{array} \\
& \text { C } \quad-2.495472 \quad 2.000424-1.401893 \\
& \mathrm{H} \quad-2.974506 \quad 1.186114-1.941275 \\
& \begin{array}{llll}
\text { C } & -2.512012 & 3.287959 & -1.943680
\end{array} \\
& \text { C } \quad-1.801196 \quad 4.292808 \quad-1.266733 \\
& \begin{array}{llll}
\text { C } & -1.100638 & 4.054011 & -0.080810
\end{array} \\
& \begin{array}{llll}
\text { C } & -1.145420 & 2.755590 & 0.440775
\end{array} \\
& \mathrm{H} \quad-0.618022 \quad 2.527196 \quad 1.367535 \\
& \begin{array}{llll}
\text { C } & -5.051085 & 4.594104 & -3.085675
\end{array} \\
& \mathrm{H} \quad-5.606537 \quad 4.874750 \quad-3.988473 \\
& \mathrm{H} \quad-4.838070 \quad 5.510801 \quad-2.523979 \\
& \mathrm{H} \quad-5.707653 \quad 3.970274 \quad-2.468604 \\
& \begin{array}{llll}
\text { C } & -2.393619 & 4.797547 & -4.605025
\end{array} \\
& \text { H } \quad-1.357089 \quad 4.447545 \quad-4.658427 \\
& \mathrm{H} \quad-2.369133 \quad 5.814823 \quad-4.196253 \\
& \text { H } \quad-2.792695 \quad 4.867336 \quad-5.623852 \\
& \text { C } \quad-3.902306 \quad 2.067993 \quad-4.396360 \\
& \mathrm{H} \quad-4.697678 \quad 1.543351 \quad-3.853217 \\
& \text { H } \quad-3.045374 \quad 1.389189 \quad-4.461977
\end{aligned}
$$




$\begin{array}{lccc}\mathrm{H} & -4.273209 & 2.260764 & -5.409759 \\ \mathrm{C} & 1.748787 & 4.935493 & 0.669790 \\ \mathrm{H} & 2.084507 & 4.977712 & -0.372042 \\ \mathrm{H} & 1.950676 & 3.923553 & 1.040220 \\ \mathrm{H} & 2.358688 & 5.635183 & 1.254200 \\ \mathrm{C} & -0.572478 & 5.368795 & 2.633478 \\ \mathrm{H} & 0.037725 & 6.078211 & 3.204907 \\ \mathrm{H} & -0.438209 & 4.379457 & 3.086754 \\ \mathrm{H} & -1.624265 & 5.649185 & 2.758769 \\ \mathrm{C} & -0.402362 & 7.049841 & 0.036989 \\ \mathrm{H} & 0.163163 & 7.828747 & 0.561168 \\ \mathrm{H} & -1.463532 & 7.319369 & 0.085934 \\ \mathrm{H} & -0.096515 & 7.072172 & -1.015472 \\ \mathrm{O} & 0.587812 & 2.858273 & -4.462288 \\ \mathrm{O} & -0.637192 & 0.969202 & -4.047677 \\ \mathrm{O} & 0.640199 & -1.828215 & -3.777019 \\ \mathrm{O} & -0.536121 & -3.790980 & -3.799998 \\ \mathrm{P} & 1.686914 & -0.096755 & 0.595801 \\ \mathrm{P} & -1.723214 & 0.073360 & 0.571290 \\ \mathrm{Cu} & -0.034696 & 0.043670 & 2.130449 \\ \mathrm{H} & -0.030436 & 0.052211 & 3.688912 \\ \mathrm{Si} & -4.868216 & -2.075464 & 4.628303 \\ \mathrm{Si} & -7.364095 & -0.146258 & -0.196394 \\ \mathrm{Si} & -0.082688 & 5.363989 & 0.815093 \\ \mathrm{Si} & -3.460869 & 3.678878 & -3.522342 \\ \mathrm{Si} & 0.239393 & -5.344002 & 1.615445 \\ \mathrm{Si} & 3.629955 & -4.196317 & -2.889032 \\ \mathrm{Si} & 4.529531 & 3.534295 & 3.759283 \\ \mathrm{Si} & 7.381577 & -0.055446 & 0.322013 \\ \mathrm{H} & -6.887658 & -1.350253 & 2.494001 \\ \mathrm{H} & -1.785550 & 5.296732 & -1.690281 \\ \mathrm{H} & 1.967971 & -5.584677 & -0.870107 \\ \mathrm{H} & 6.662738 & 2.086671 & 2.269283\end{array}$




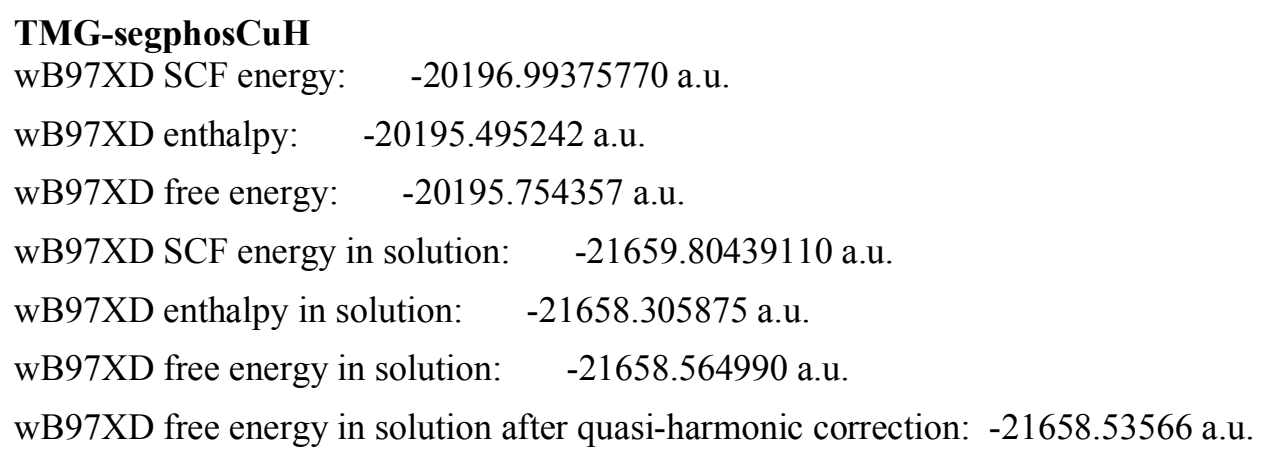

$\begin{array}{lrcc}\text { ATOM } & \text { X } & \text { Y } & \text { Z } \\ \text { C } & 3.373545 & 0.337428 & 1.076704 \\ \text { C } & 3.448258 & 1.309479 & 2.076696 \\ \text { H } & 2.522203 & 1.654518 & 2.534034 \\ \text { C } & 4.675014 & 1.828739 & 2.497287 \\ \text { C } & 5.833266 & 1.311186 & 1.908768 \\ \text { C } & 5.800817 & 0.307802 & 0.933112 \\ \text { C } & 4.552182 & -0.160432 & 0.521992 \\ \text { H } & 4.494516 & -0.933382 & -0.237956 \\ \text { C } & 2.939965 & 3.613660 & 4.474637 \\ \text { H } & 2.322032 & 4.015697 & 3.666263 \\ \text { H } & 2.956424 & 4.348205 & 5.285955 \\ \text { H } & 2.462164 & 2.701734 & 4.846765 \\ \text { C } & 5.545655 & 4.828775 & 3.007768 \\ \text { H } & 6.557160 & 4.610345 & 2.649894 \\ \text { H } & 5.606249 & 5.661163 & 3.716114 \\ \text { H } & 4.942907 & 5.144263 & 2.150620 \\ \text { C } & 5.895941 & 2.639445 & 5.320984 \\ \text { H } & 5.454549 & 1.766688 & 5.811213 \\ \text { H } & 6.020534 & 3.430336 & 6.067415 \\ \text { H } & 6.888051 & 2.358770 & 4.952541 \\ \text { C } & 8.348162 & 0.996502 & -0.853808 \\ \text { H } & 9.294112 & 0.636261 & -1.270418 \\ \text { H } & 8.564651 & 1.846983 & -0.199347 \\ \text { H } & 7.720067 & 1.351780 & -1.676369 \\ \text { C } & 8.593545 & -1.083476 & 1.575865 \\ \text { H } & 9.539219 & -1.458766 & 1.172196\end{array}$




\begin{tabular}{|c|c|c|c|}
\hline$H$ & 8.101973 & -1.894788 & 2.120831 \\
\hline & 8.820182 & -0.283870 & 2.288445 \\
\hline$C$ & 6.912067 & -1.881222 & -1.055611 \\
\hline & 6.290603 & -1.507186 & -1.876481 \\
\hline & 6.338200 & -2.637152 & -0.509416 \\
\hline & 7.792255 & -2.365581 & -1.489583 \\
\hline & 1.802279 & -1.838783 & -0.112220 \\
\hline & 1.069894 & -2.801932 & 0.582426 \\
\hline & 0.530514 & -2.497946 & 1.479816 \\
\hline & 0.992674 & -4.125110 & 0.143605 \\
\hline & 1.703753 & -4.463835 & -1.009130 \\
\hline $\mathrm{C}$ & 2.460586 & -3.530414 & -1.730397 \\
\hline & 2.483426 & -2.212805 & -1.273833 \\
\hline & 3.006125 & -1.452270 & -1.850451 \\
\hline & 0.390679 & -5.265961 & 3.035651 \\
\hline IT & -0.264346 & -5.888126 & 3.654007 \\
\hline & 0.308520 & -4.232448 & 3.388601 \\
\hline & 1.423845 & -5.594206 & 3.183652 \\
\hline & -2.002225 & -4.903536 & 0.959912 \\
\hline U & -2.618028 & -5.527313 & 1.616431 \\
\hline & -2.340339 & -5.041239 & -0.071126 \\
\hline & -2.160267 & -3.855110 & 1.232667 \\
\hline & 0.190560 & -7.189476 & 0.441576 \\
\hline & 1.247612 & -7.463392 & 0.516805 \\
\hline & -0.106924 & -7.249630 & -0.610421 \\
\hline & -0.393685 & -7.926305 & 1.001339 \\
\hline C & 2.323180 & -5.322025 & -4.335580 \\
\hline & 1.268975 & -5.033074 & -4.284610 \\
\hline & 2.415740 & -6.327750 & -3.912557 \\
\hline $\mathrm{H}$ & 2.628626 & -5.373241 & -5.385821 \\
\hline & 3.884792 & -2.456500 & -4.358301 \\
\hline & 3.036686 & -1.766387 & -4.389305 \\
\hline & 4.173724 & -2.713702 & -5.382370 \\
\hline & 4.728562 & -1.934712 & -3.894353 \\
\hline & 5.103448 & -4.966568 & -2.799784 \\
\hline & 5.631904 & -5.356221 & -3.675875 \\
\hline & 4.887663 & -5.803052 & -2.127544 \\
\hline
\end{tabular}




\begin{tabular}{|c|c|c|c|}
\hline & 5.766423 & -4.268847 & -2.278863 \\
\hline & 1.478406 & 0.896973 & -0.993617 \\
\hline & 2.246243 & 2.051485 & -1.159366 \\
\hline & 3.039670 & 2.266674 & -0.452924 \\
\hline & 2.044798 & 2.954878 & -2.211940 \\
\hline & 2.651943 & 3.846118 & -2.319840 \\
\hline & 1.049355 & 2.642880 & -3.104057 \\
\hline & -0.198677 & 2.410799 & -4.907829 \\
\hline & 0.384295 & 1.924958 & -5.703623 \\
\hline & -1.067043 & 2.934665 & -5.309087 \\
\hline $\mathrm{C}$ & 0.287849 & 1.493048 & -2.959586 \\
\hline & 0.440319 & 0.601059 & -1.918454 \\
\hline & -0.440319 & -0.601069 & -1.918453 \\
\hline 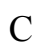 & -0.287848 & -1.493061 & -2.959582 \\
\hline 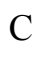 & 0.198679 & -2.410818 & -4.907822 \\
\hline $\mathrm{H}$ & -0.384293 & -1.924978 & -5.703616 \\
\hline 11 & 1.067044 & -2.934684 & -5.309080 \\
\hline 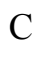 & -1.049354 & -2.642893 & -3.104051 \\
\hline C & -2.044799 & -2.954889 & -2.211935 \\
\hline & -2.651944 & -3.846128 & -2.319832 \\
\hline 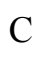 & -2.246245 & -2.051492 & -1.159363 \\
\hline $\mathrm{H}$ & -3.039674 & -2.266678 & -0.452922 \\
\hline C & -1.478407 & -0.896980 & -0.993616 \\
\hline & -3.37 & -0.337426 & 1.076 \\
\hline C & -4.552183 & 0.160444 & 0.521992 \\
\hline $\mathrm{H}$ & -4.494514 & 0.933397 & -0.237952 \\
\hline C & -5.800821 & -0.307783 & 0.933113 \\
\hline & -5.833274 & -1.311171 & 1.908765 \\
\hline$C$ & -4.675025 & -1.828735 & 2.497278 \\
\hline $\mathrm{C}$ & -3.448267 & -1.309482 & 2.076687 \\
\hline 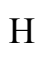 & -2.522212 & -1.654529 & 2.534022 \\
\hline & -8.593545 & 1.083499 & 1.575874 \\
\hline $\mathrm{H}$ & -9.539215 & 1.458801 & 1.172207 \\
\hline & -8.101970 & 1.894801 & 2.120853 \\
\hline & -8.820191 & 0.283886 & 2.288442 \\
\hline & -6.912058 & 1.881265 & -1.055591 \\
\hline & -7.792244 & 2.365636 & -1.489554 \\
\hline
\end{tabular}




\begin{tabular}{|c|c|c|c|}
\hline & -6.290601 & 1.507233 & -1.876468 \\
\hline & -6.338182 & 2.637184 & -0.509391 \\
\hline & -8.348165 & -0.996455 & -0.853819 \\
\hline & -8.564661 & -1.846940 & -0.199367 \\
\hline & -7.720068 & -1.351729 & -1.676381 \\
\hline & -9.294111 & -0.636204 & -1.270430 \\
\hline & -5.545654 & -4.828777 & 3.007736 \\
\hline & -4.942893 & -5.144261 & 2.150595 \\
\hline & -6.557154 & -4.610349 & 2.649847 \\
\hline & -5.606257 & -5.661169 & 3.716078 \\
\hline & -5.895971 & -2.639462 & 5.320960 \\
\hline & -6.888079 & -2.358787 & 4.952509 \\
\hline & -5.454587 & -1.766706 & 5.811199 \\
\hline & -6.020571 & -3.430357 & 6.067386 \\
\hline & -2.939983 & -3.613658 & 4.474634 \\
\hline & -2.956446 & -4.348208 & 5.285948 \\
\hline & -2.462190 & -2.701731 & 4.846771 \\
\hline & -2.322040 & -4.015688 & 3.666264 \\
\hline & -1.802276 & 1.838778 & -0.112226 \\
\hline & -2.483424 & 2.212800 & -1.273838 \\
\hline & -3.006126 & 1.452267 & -1.850454 \\
\hline & -2.460580 & 3.530409 & -1.730404 \\
\hline & -1.703745 & 4.463829 & -1.009138 \\
\hline & -0.992666 & 4.125104 & 0.143597 \\
\hline & -1.069889 & 2.801926 & 0.582419 \\
\hline & -0.530509 & 2.497940 & 1.479809 \\
\hline & -5.103442 & 4.966565 & -2.799792 \\
\hline & -5.631899 & 5.356213 & -3.675884 \\
\hline & -4.887656 & 5.803052 & -2.127556 \\
\hline & -5.766416 & 4.268846 & -2.278867 \\
\hline & -2.323173 & 5.322016 & -4.335590 \\
\hline & -1.268968 & 5.033063 & -4.284620 \\
\hline & -2.415732 & 6.327742 & -3.912570 \\
\hline & -2.628620 & 5.373229 & -5.385831 \\
\hline & -3.884788 & 2.456494 & -4.358305 \\
\hline & -4.728559 & 1.934707 & -3.894358 \\
\hline & -3.036683 & 1.766380 & -4.389309 \\
\hline
\end{tabular}




$\begin{array}{lccc}\mathrm{H} & -4.173719 & 2.713695 & -5.382375 \\ \mathrm{C} & 2.002234 & 4.903517 & 0.959919 \\ \mathrm{H} & 2.340358 & 5.041212 & -0.071116 \\ \mathrm{H} & 2.160267 & 3.855092 & 1.232681 \\ \mathrm{H} & 2.618034 & 5.527294 & 1.616440 \\ \mathrm{C} & -0.390677 & 5.265967 & 3.035641 \\ \mathrm{H} & 0.264350 & 5.888130 & 3.653996 \\ \mathrm{H} & -0.308526 & 4.232455 & 3.388595 \\ \mathrm{H} & -1.423842 & 5.594219 & 3.183637 \\ \mathrm{C} & -0.190537 & 7.189466 & 0.441554 \\ \mathrm{H} & 0.393709 & 7.926296 & 1.001316 \\ \mathrm{H} & -1.247588 & 7.463389 & 0.516774 \\ \mathrm{H} & 0.106955 & 7.249612 & -0.610442 \\ \mathrm{O} & 0.630846 & 3.330026 & -4.210734 \\ \mathrm{O} & -0.628244 & 1.431625 & -3.975227 \\ \mathrm{O} & 0.628247 & -1.431642 & -3.975222 \\ \mathrm{O} & -0.630843 & -3.330044 & -4.210725 \\ \mathrm{P} & 1.701642 & -0.129829 & 0.519991 \\ \mathrm{P} & -1.701644 & 0.129826 & 0.519989 \\ \mathrm{Cu} & -0.000003 & -0.000009 & 2.069325 \\ \mathrm{H} & -0.000005 & -0.000027 & 3.626137 \\ \mathrm{H} & -6.801237 & -1.699360 & 2.228282 \\ \mathrm{H} & -1.657881 & 5.490416 & -1.371155 \\ \mathrm{H} & 1.657891 & -5.490422 & -1.371146 \\ \mathrm{H} & 6.801226 & 1.699381 & 2.228285 \\ \mathrm{Ge} & -4.754890 & -3.241639 & 3.846112 \\ \mathrm{Ge} & -7.432491 & 0.420260 & 0.144363 \\ \mathrm{Ge} & -0.110992 & -5.387343 & 1.146952 \\ \mathrm{Ge} & 3.444828 & -4.064803 & -3.326649 \\ \mathrm{Ge} & 0.111001 & 5.387336 & 1.146942 \\ \mathrm{Ge} & -3.444823 & 4.064798 & -3.326656 \\ \mathrm{Ge} & 4.754875 & 3.241635 & 3.846128 \\ \mathrm{Ge} & 7.432492 & -0.420227 & 0.144357\end{array}$




\section{TS-1A}

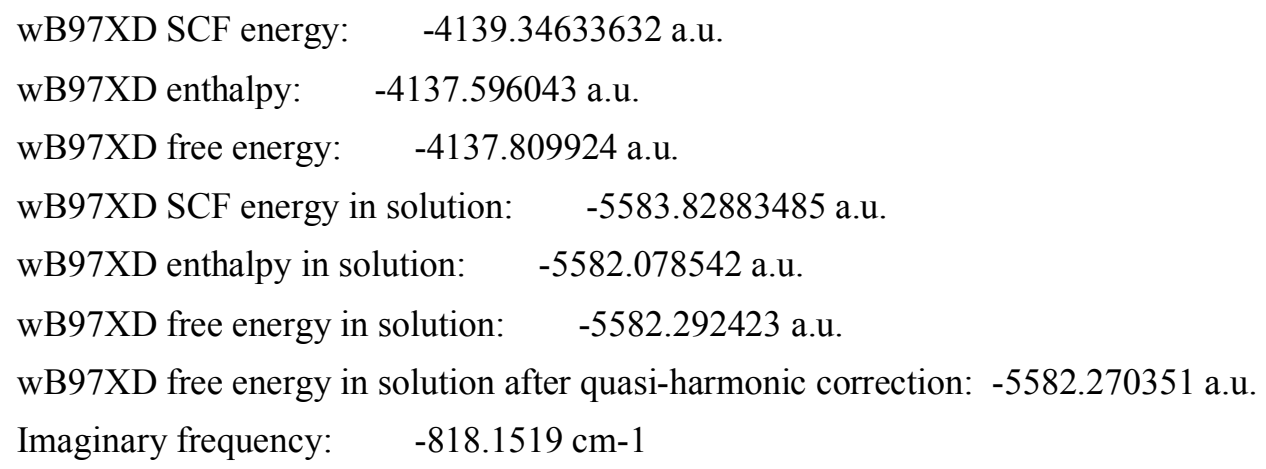

Cartesian coordinates

\begin{tabular}{|c|c|c|c|}
\hline ATOI & $M$ & Y & Z \\
\hline $\mathrm{P}$ & 1.908416 & -0.272367 & -0.448065 \\
\hline$P$ & -1.535840 & 0.200256 & -0.169427 \\
\hline $\mathrm{O}$ & 1.410490 & 1.281817 & 4.047768 \\
\hline $\mathrm{O}$ & 0.644861 & 3.418934 & 4.342638 \\
\hline $\mathrm{O}$ & -0.637022 & -1.243841 & 4.082343 \\
\hline $\mathrm{O}$ & 0.198986 & -3.367405 & 4.323410 \\
\hline $\mathrm{C}$ & -0.934056 & 1.273930 & 1.200950 \\
\hline $\mathrm{C}$ & 0.058271 & 0.735445 & 2.064562 \\
\hline $\mathrm{C}$ & 0.485144 & 1.564928 & 3.079708 \\
\hline $\mathrm{C}$ & 0.023100 & 2.861322 & 3.257722 \\
\hline $\mathrm{C}$ & -0.916812 & 3.405614 & 2.418327 \\
\hline $\mathrm{C}$ & -1.391400 & 2.577566 & 1.389359 \\
\hline $\mathrm{C}$ & 1.249282 & 2.315013 & 5.005177 \\
\hline $\mathrm{C}$ & 1.571833 & -1.167191 & 1.126869 \\
\hline $\mathrm{C}$ & 2.100388 & -2.444362 & 1.316278 \\
\hline $\mathrm{C}$ & 1.711514 & -3.277308 & 2.373922 \\
\hline $\mathrm{C}$ & 0.756918 & -2.779959 & 3.224232 \\
\hline $\mathrm{C}$ & 0.242634 & -1.499812 & 3.067825 \\
\hline $\mathrm{C}$ & 0.612391 & -0.651720 & 2.043495 \\
\hline $\mathrm{C}$ & -0.870726 & -2.505553 & 4.690571 \\
\hline $\mathrm{C}$ & -2.290717 & -1.170853 & 0.780876 \\
\hline $\mathrm{C}$ & -3.149192 & -0.925273 & 1.852106 \\
\hline $\mathrm{C}$ & -3.750777 & -1.973524 & 2.544589 \\
\hline $\mathrm{C}$ & -3.456007 & -3.280940 & 2.133012 \\
\hline $\mathrm{C}$ & -2.589263 & -3.558145 & 1.072814 \\
\hline
\end{tabular}



$\begin{array}{llll}\text { C } & -2.006214 & -2.477705 & 0.405329\end{array}$
$\begin{array}{llll}\text { C } & -0.757102 & -5.243392 & 0.827752\end{array}$
$\begin{array}{llll}\text { C } & -3.051564 & -6.046139 & 1.383089\end{array}$
$\begin{array}{llll}\text { C } & -2.594715 & -5.118875 & -0.886837\end{array}$
$\begin{array}{llll}\text { C } & -5.992770 & -1.007542 & 3.058830\end{array}$
$\begin{array}{llll}\text { C } & -4.110132 & -0.683656 & 4.687456\end{array}$
$\begin{array}{llll}\text { C } & -5.176416 & -2.918870 & 4.438935\end{array}$
$\begin{array}{llll}\text { C } & -2.985430 & 1.067014 & -0.877861\end{array}$
$\begin{array}{llll}\text { C } & -2.767376 & 2.259548 & -1.564948\end{array}$
C $\quad-4.265532 \quad 0.506152 \quad-0.869833$
$\begin{array}{llll}\text { C } & -5.329189 & 1.138794 & -1.509481\end{array}$
$\begin{array}{llll}\text { C } & -5.082522 & 2.362735 & -2.144420\end{array}$
$\begin{array}{lllll}\text { C } & -3.815537 & 2.942559 & -2.188761\end{array}$
C $\quad-2.936813 \quad 5.268247 \quad-1.873843$
$\begin{array}{lllll}\text { C } & -2.525829 & 4.043674 & -4.035597\end{array}$
$\begin{array}{lllll}\text { C } & -4.799270 & 4.903368 & -3.487542\end{array}$
$\begin{array}{llll}\text { C } & -6.788846 & -0.865114 & -0.920756\end{array}$
$\begin{array}{llll}\text { C } & -7.339526 & 0.524093 & -2.909725\end{array}$
$\begin{array}{llll}\text { C } & -7.628415 & 1.463366 & -0.595420\end{array}$
$\begin{array}{llll}\text { C } & 2.454656 & 1.390611 & 0.079294\end{array}$
$\begin{array}{llll}\text { C } & 1.971907 & 2.464463 & -0.664434\end{array}$
$\begin{array}{llll}\text { C } & 2.301627 & 3.775759 & -0.324435\end{array}$
$\begin{array}{llll}\text { C } & 3.152211 & 3.967182 & 0.765508\end{array}$
$\begin{array}{llll}\text { C } & 3.657304 & 2.911450 & 1.532164\end{array}$
$\begin{array}{llll}\text { C } & 3.280748 & 1.615054 & 1.181430\end{array}$
$\begin{array}{llll}\text { C } & 5.969665 & 3.650535 & 2.108885\end{array}$
$\begin{array}{llll}\text { C } & 4.048678 & 4.329937 & 3.578213\end{array}$
$\begin{array}{llll}\text { C } & 4.849099 & 1.962482 & 3.566957\end{array}$
$\begin{array}{llll}\text { C } & 2.843846 & 5.913833 & -1.545798\end{array}$
$\begin{array}{llll}\text { C } & 0.901516 & 4.548926 & -2.298212\end{array}$
C $\quad 5.593664 \quad-2.514293 \quad-2.023350$
$\begin{array}{lllll}\text { C } & 5.815772 & -1.343163 & -1.284707\end{array}$
$\begin{array}{llll}\text { C } & 8.006561 & -1.979258 & -0.237742\end{array}$
$\begin{array}{llll}\text { C } & 4.706685 & -0.646218 & -0.817046\end{array}$
$\begin{array}{llll}\text { C } & 3.411889 & -1.090671 & -1.095705\end{array}$
$\begin{array}{lllll}\text { C } & 3.224918 & -2.236459 & -1.864152\end{array}$
$\begin{array}{llll}\text { C } & 4.316433 & -2.985874 & -2.319834\end{array}$ 


$$
\begin{aligned}
& \begin{array}{llll}
\text { C } & 7.963692 & -0.598298 & -2.342019
\end{array} \\
& \begin{array}{llll}
\text { C } & 3.212422 & -4.008427 & -4.333349
\end{array} \\
& \begin{array}{llll}
\text { C } & 3.308720 & -5.265824 & -2.159389
\end{array} \\
& \begin{array}{llll}
\text { C } & 7.290170 & 0.405232 & -0.161879
\end{array} \\
& \begin{array}{llll}
\text { C } & 0.779334 & 5.738467 & -0.111915
\end{array} \\
& \begin{array}{llll}
\text { C } & 5.369469 & -4.966630 & -3.532261
\end{array} \\
& \mathrm{H} \quad-1.287657 \quad 4.415248 \quad 2.552388 \\
& \mathrm{H} \quad-2.161355 \quad 2.971076 \quad 0.735426 \\
& \mathrm{H} \quad 2.226551 \quad 2.611305 \quad 5.387717 \\
& \text { H } \quad 0.586739 \quad 1.966544 \quad 5.810557 \\
& \text { H } \quad 2.832232 \quad-2.824859 \quad 0.613039 \\
& \text { H } \quad 2.130389-4.268745 \quad 2.501282 \\
& \mathrm{H} \quad-1.816290 \quad-2.918902 \quad 4.313334 \\
& \mathrm{H} \quad-0.885290 \quad-2.386815 \quad 5.775515 \\
& \mathrm{H} \quad-3.353853 \quad 0.104747 \quad 2.131049 \\
& \text { H } \quad-1.312999 \quad-2.633284 \quad-0.418614 \\
& \text { H } \quad-0.139173 \quad-4.519185 \quad 0.286914 \\
& \text { H } \quad-0.491346 \quad-6.248382 \quad 0.477684 \\
& \mathrm{H} \quad-0.501836 \quad-5.169246 \quad 1.890680 \\
& \text { H } \quad-2.819319-6.029356 \quad 2.454165 \\
& \mathrm{H} \quad-2.792343 \quad-7.041686 \quad 1.006580 \\
& \mathrm{H} \quad-4.133027 \quad-5.915658 \quad 1.260632 \\
& \text { H } \quad-3.654609-4.908381-1.070055 \\
& \mathrm{H} \quad-2.383297 \quad-6.138716-1.229810 \\
& \mathrm{H} \quad-2.005364 \quad-4.431042-1.501571 \\
& \mathrm{H} \quad-6.718554 \quad-0.750179 \quad 3.839720 \\
& \mathrm{H} \quad-6.477810 \quad-1.692502 \quad 2.354353 \\
& \mathrm{H} \quad-5.738384 \quad-0.089979 \quad 2.516427 \\
& \mathrm{H} \quad-4.832285 \quad-0.446616 \quad 5.477566 \\
& \mathrm{H} \quad-3.805727 \quad 0.257784 \quad 4.221507 \\
& \text { H } \quad-3.222579 \quad-1.117249 \quad 5.158414 \\
& \mathrm{H} \quad-4.320380 \quad-3.442601 \quad 4.880992 \\
& \mathrm{H} \quad-5.714013 \quad-3.623240 \quad 3.794913 \\
& \text { H } \quad-5.852238 \quad-2.639457 \quad 5.254639 \\
& \mathrm{H} \quad-1.755684 \quad 2.652606 \quad-1.617409 \\
& \mathrm{H} \quad-4.420361 \quad-0.438857 \quad-0.366042 \\
& \text { H } \quad-2.715163 \quad 6.225692 \quad-2.360379
\end{aligned}
$$




\begin{tabular}{|c|c|c|c|}
\hline & -2.004387 & 4.896537 & -1.437663 \\
\hline & -3.641833 & 5.455263 & -1.055698 \\
\hline & -2.920221 & 3.323031 & -4.760307 \\
\hline & -1.570778 & 3.657142 & -3.668672 \\
\hline & -2.323648 & 4.985226 & -4.560274 \\
\hline & -5.249363 & 4.260977 & -4.252735 \\
\hline & -4.546729 & 5.856834 & -3.964187 \\
\hline & -5.552913 & 5.106552 & -2.718104 \\
\hline & -6.458935 & -0.900040 & 0.122599 \\
\hline & -6.159423 & -1.547418 & -1.502643 \\
\hline & -7.816110 & -1.244916 & -0.953124 \\
\hline & -8.350288 & 0.100312 & -2.885489 \\
\hline & -6.726494 & -0.096366 & -3.571856 \\
\hline & -7.413183 & 1.521401 & -3.354648 \\
\hline & -7.662559 & 2.490310 & -0.975391 \\
\hline & -7.236436 & 1.495478 & 0.427515 \\
\hline & -8.655837 & 1.081721 & -0.557199 \\
\hline & 1.310842 & 2.243942 & -1.496564 \\
\hline & 3.607207 & 0.766095 & 1.773101 \\
\hline & 5.857563 & 4.545141 & 1.486463 \\
\hline & 6.404642 & 2.860298 & 1.486407 \\
\hline & 6.677634 & 3.882218 & 2.914104 \\
\hline & 4.658523 & 4.445084 & 4.482063 \\
\hline & 3.014936 & 4.122605 & $3.8^{\prime}$ \\
\hline & 4.052168 & 5.295806 & 3.062660 \\
\hline & 5.482637 & 2.225795 & 4.421301 \\
\hline & 5.364151 & 1.168766 & 3.013898 \\
\hline & 3.906769 & 1.551970 & 3.944502 \\
\hline & 2.423452 & 6.768213 & -2.089336 \\
\hline & 3.529788 & 5.385208 & -2.216772 \\
\hline & 3.428717 & 6.310442 & -0.709428 \\
\hline & 0.062156 & 3.905504 & -2.015499 \\
\hline & 1.511626 & 4.000576 & -3.024430 \\
\hline & 0.487276 & 5.431160 & -2.799110 \\
\hline & 7.510985 & -2.198522 & 0.714485 \\
\hline & 9.032949 & -1.657857 & -0.024370 \\
\hline & 8.061974 & -2.910918 & -0.810290 \\
\hline
\end{tabular}




\begin{tabular}{|c|c|c|c|}
\hline $\mathrm{H}$ & 4.835492 & 0.257356 & -0.235622 \\
\hline $\mathrm{H}$ & 2.205904 & -2.548608 & -2.086259 \\
\hline & 8.991849 & -0.261886 & -2.162571 \\
\hline & 7.440169 & 0.182304 & -2.904669 \\
\hline & 8.009778 & -1.492898 & -2.971853 \\
\hline$\pi$ & 3.710037 & -3.288649 & -4.992721 \\
\hline 1 & 2.231969 & -3.601446 & -4.070545 \\
\hline & 3.048103 & -4.934223 & -4.897482 \\
\hline & 3.113851 & -6.211412 & -2.679363 \\
\hline & 2.345222 & -4.853464 & -1.841262 \\
\hline $\mathrm{H}$ & 3.896265 & -5.484316 & -1.260264 \\
\hline$t$ & 6.818605 & 0.261583 & 0.817473 \\
\hline & 6.788447 & 1.239500 & -0.664929 \\
\hline 1 & 8.331244 & 0.699039 & 0.011868 \\
\hline $\mathrm{H}$ & -0.021913 & 5.078369 & 0.238605 \\
\hline & 0.324785 & 6.598990 & -0.617976 \\
\hline & 1.316882 & 6.105885 & 0.769185 \\
\hline H & 5.136713 & -5.890655 & -4.072679 \\
\hline $\mathrm{H}$ & 6.004655 & -5.234065 & -2.680104 \\
\hline 11 & 5.947057 & -4.324490 & -4.206975 \\
\hline $\mathrm{Cu}$ & 0.064524 & -0.284738 & -1.695786 \\
\hline $\mathrm{H}$ & -0.330309 & -1.650238 & -2.462270 \\
\hline $\mathrm{C}$ & -0.489335 & -0.587977 & -3.718783 \\
\hline & -0.009 & 0.744 & -3.480 \\
\hline $\mathrm{H}$ & -0.738993 & 1.550625 & -3.466096 \\
\hline $\mathrm{C}$ & -1.997968 & -0.715640 & -3.934180 \\
\hline$H$ & -2.165782 & -0.617998 & -5.018669 \\
\hline n & -2.493317 & 0.145652 & -3.470124 \\
\hline $\mathrm{H}$ & 0.977743 & 1.012447 & -3.853741 \\
\hline $\mathrm{C}$ & 0.363262 & -1.460854 & -4.627311 \\
\hline $\mathrm{H}$ & 1.418904 & -1.382929 & -4.350073 \\
\hline & 0.072571 & -2.516152 & -4.580952 \\
\hline $\mathrm{H}$ & 3.424073 & 4.982490 & 1.040157 \\
\hline $\mathrm{H}$ & -5.911488 & 2.872767 & -2.621740 \\
\hline & -3.919617 & -4.107977 & 2.656016 \\
\hline & 6.454787 & -3.070677 & -2.377324 \\
\hline & 0.257061 & -1.113571 & -5.664413 \\
\hline
\end{tabular}



$\begin{array}{llll}\text { C } & -2.685913 & -1.986030 & -3.437447\end{array}$
$\mathrm{H} \quad-2.592167 \quad-2.035900 \quad-2.347048$
$\mathrm{H} \quad-2.177757 \quad-2.875813 \quad-3.832425$
$\begin{array}{llll}\text { C } & -4.164993 & -2.014933 & -3.815935\end{array}$
H $\quad-4.666055 \quad-2.899819 \quad-3.407119$
$\mathrm{H} \quad-4.670472 \quad-1.125730 \quad-3.420076$
H $\quad-4.303842 \quad-2.020807 \quad-4.903804$
$\begin{array}{llll}\text { C } & 7.250588 & -0.878078 & -1.005507\end{array}$
$\begin{array}{llll}\text { C } & 4.066030 & -4.291736 & -3.084008\end{array}$
$\begin{array}{llll}\text { C } & -2.259400 & -4.982194 & 0.611615\end{array}$
$\begin{array}{llll}\text { C } & -4.739951 & -1.660154 & 3.676079\end{array}$
$\begin{array}{llll}\text { C } & -6.751498 & 0.562355 & -1.486513\end{array}$
$\begin{array}{llll}\text { C } & -3.531573 & 4.275659 & -2.891990\end{array}$
$\begin{array}{llll}\text { C } & 1.716363 & 4.979637 & -1.071075\end{array}$
$\begin{array}{llll}\text { C } & 4.615491 & 3.203151 & 2.692489\end{array}$ 


\section{TS-1B}

wB97XD SCF energy: $\quad-4139.34507885$ a.u.

wB97XD enthalpy: $\quad-4137.594933$ a.u.

wB97XD free energy: $\quad-4137.809954$ a.u.

wB97XD SCF energy in solution: $\quad-5583.82710267$ a.u.

wB97XD enthalpy in solution: $\quad-5582.076957$ a.u.

wB97XD free energy in solution: $\quad-5582.291978$ a.u.

wB97XD free energy in solution after quasi-harmonic correction: -5582.269685 a.u.

Imaginary frequency: $\quad-777.5653 \mathrm{~cm}-1$

Cartesian coordinates
$\begin{array}{llll}\text { ATOM } & \mathrm{X} & \mathrm{Y} & \mathrm{Z}\end{array}$
$\begin{array}{llll}\mathrm{P} & 1.588909 & 0.186300 & -0.051335\end{array}$
$\begin{array}{llll}\mathrm{P} & -1.810051 & -0.176389 & 0.498374\end{array}$
O $\quad 0.551511-2.596982-3.573844$
O $\quad-0.256474-4.680256-3.050256$
O $\quad-1.472978-0.210513-4.303527$
O $\quad-0.754058 \quad 1.718711 \quad-5.303069$
C $\quad-1.498944-1.546812-0.690562$
C $\quad-0.602651-1.361483-1.781976$
C $\quad-0.266632-2.502246-2.483417$
$\begin{array}{llll}\text { C } & -0.755718 & -3.763193 & -2.170246\end{array}$
C $\quad-1.633048 \quad-3.957624-1.133204$
$\begin{array}{llll}\text { C } & -1.990146 & -2.819050 & -0.397267\end{array}$
$\begin{array}{llll}\text { C } & 0.767399 & -3.989325 & -3.754702\end{array}$
C $\quad 0.935346 \quad 0.741140 \quad-1.678450$
$\begin{array}{llll}\text { C } & 1.367129 & 1.913583 & -2.296816\end{array}$
$\begin{array}{llll}\text { C } & 0.853314 & 2.353016 & -3.526748\end{array}$
$\begin{array}{llll}\text { C } & -0.095360 & 1.553154 & -4.113920\end{array}$
C $\quad-0.530584 \quad 0.382732 \quad-3.507750$
$\begin{array}{llll}\text { C } & -0.069582 & -0.060056 & -2.286448\end{array}$
$\begin{array}{llll}\text { C } & -1.350905 & 0.452336 & -5.551121\end{array}$
$\begin{array}{llll}\text { C } & -2.396097 & 1.200228 & -0.552434\end{array}$
$\begin{array}{llll}\text { C } & -3.250093 & 1.013697 & -1.640701\end{array}$
$\begin{array}{llll}\text { C } & -3.685526 & 2.102083 & -2.395532\end{array}$
$\begin{array}{llll}\text { C } & -3.205658 & 3.369457 & -2.047544\end{array}$
$\begin{array}{llll}\text { C } & -2.327168 & 3.583837 & -0.984409\end{array}$ 

$\begin{array}{llll}\text { C } & -1.940340 & 2.475607 & -0.230701\end{array}$
C $\quad-1.771474 \quad 4.985999 \quad-0.710263$
$\begin{array}{llll}\text { C } & -0.836227 & 5.370453 & -1.872812\end{array}$
$\begin{array}{llll}\text { C } & -2.917045 & 6.008592 & -0.603427\end{array}$
$\begin{array}{llll}\text { C } & -0.964815 & 5.034988 & 0.594278\end{array}$
$\begin{array}{llll}\text { C } & -4.686526 & 1.954198 & -3.546952\end{array}$
$\begin{array}{llll}\text { C } & -4.883333 & 0.485597 & -3.951352\end{array}$
$\begin{array}{llll}\text { C } & -4.200563 & 2.742885 & -4.778738\end{array}$
$\begin{array}{lllll}\text { C } & -6.044888 & 2.518154 & -3.086534\end{array}$
$\begin{array}{llll}\text { C } & -3.295289 & -0.706276 & 1.429198\end{array}$
$\begin{array}{llll}\text { C } & -3.071227 & -1.411219 & 2.618141\end{array}$
$\begin{array}{llll}\text { C } & -4.595298 & -0.425516 & 1.032286\end{array}$
$\begin{array}{llll}\text { C } & -5.691060 & -0.844776 & 1.794823\end{array}$
$\begin{array}{llll}\text { C } & -5.435018 & -1.557592 & 2.963500\end{array}$
$\begin{array}{llll}\text { C } & -4.134051 & -1.853312 & 3.398978\end{array}$
$\begin{array}{llll}\text { C } & -3.926118 & -2.626075 & 4.706968\end{array}$
$\begin{array}{llll}\text { C } & -2.439251 & -2.849882 & 5.018226\end{array}$
$\begin{array}{llll}\text { C } & -4.544747 & -1.829508 & 5.871618\end{array}$
$\begin{array}{llll}\text { C } & -4.610078 & -4.002273 & 4.600509\end{array}$
$\begin{array}{llll}\text { C } & -7.104568 & -0.494709 & 1.313126\end{array}$
$\begin{array}{llll}\text { C } & -7.249461 & 1.038179 & 1.245371\end{array}$
$\begin{array}{llll}\text { C } & -8.192704 & -1.043121 & 2.245789\end{array}$
$\begin{array}{llll}\text { C } & -7.326533 & -1.089618 & -0.091218\end{array}$
$\begin{array}{llll}\text { C } & 2.334111 & -1.419629 & -0.517525\end{array}$
$\begin{array}{llll}\text { C } & 1.964385 & -2.551092 & 0.210173\end{array}$
$\begin{array}{llll}\text { C } & 2.459653 & -3.807035 & -0.130217\end{array}$
$\begin{array}{llll}\text { C } & 3.352779 & -3.888420 & -1.208100\end{array}$
$\begin{array}{lllll}\text { C } & 3.734360 & -2.776077 & -1.960997\end{array}$
$\begin{array}{lllll}\text { C } & 3.199781 & -1.536779 & -1.599414\end{array}$
$\begin{array}{llll}\text { C } & 4.714303 & -2.857089 & -3.138585\end{array}$
$\begin{array}{lllll}\text { C } & 5.975875 & -2.044460 & -2.788366\end{array}$
$\begin{array}{llll}\text { C } & 5.139164 & -4.298651 & -3.449537\end{array}$
C $\quad 4.065233 \quad-2.263471 \quad-4.403701$
$\begin{array}{llll}\text { C } & 3.318886 & -5.578342 & 1.407420\end{array}$
$\begin{array}{llll}\text { C } & 2.078048 & -5.071622 & 0.647734\end{array}$
$\begin{array}{llll}\text { C } & 0.957199 & -4.801291 & 1.663201\end{array}$
$\begin{array}{llll}\text { C } & 5.023353 & 2.887977 & 1.348620\end{array}$ 


\begin{tabular}{|c|c|c|c|}
\hline & 5.303785 & 1.543216 & 1.099349 \\
\hline & 7.659954 & 1.910527 & 2.003867 \\
\hline & 4.286013 & 0.745424 & 0.568598 \\
\hline & 3.014899 & 1.263232 & 0.335342 \\
\hline & 2.760373 & 2.604954 & 0.629087 \\
\hline & 3.761231 & 3.444182 & 1.112658 \\
\hline & 6.487844 & -0.253903 & 2.385938 \\
\hline & 2.376029 & 4.982777 & 2.522378 \\
\hline & 3.431786 & 4.914016 & 1.402508 \\
\hline & 2.878084 & 5.572003 & 0.123459 \\
\hline & 7.270795 & 0.370711 & 0.079908 \\
\hline & 1.592681 & -6.163696 & -0.324289 \\
\hline & 6.670132 & 0.910120 & 1.391864 \\
\hline & 4.662178 & 5.712611 & 1.854643 \\
\hline & -2.027301 & -4.938706 & -0.894190 \\
\hline & -2.669036 & -2.943642 & 0.439219 \\
\hline & 1.744643 & -4.261791 & -3.333766 \\
\hline & 0.701984 & -4.230448 & -4.817224 \\
\hline I & 2.145478 & 2.505771 & -1.828104 \\
\hline & 1.201103 & 3.266350 & -3.995438 \\
\hline & -2.341255 & 0.595196 & -5.984586 \\
\hline & -0.698626 & -0.134749 & -6.213673 \\
\hline 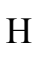 & -3.552298 & 0.004758 & -1.901909 \\
\hline & -1.257827 & 2.57 & 0.608104 \\
\hline & -0.017422 & 4.647129 & -1.957922 \\
\hline & -0.405426 & 6.365736 & -1.708241 \\
\hline & -1.370115 & 5.382528 & -2.829550 \\
\hline & -3.493201 & 6.082587 & -1.531444 \\
\hline & -2.513924 & 7.004864 & -0.386837 \\
\hline & -3.607533 & 5.736298 & 0.202345 \\
\hline & -1.574296 & 4.759499 & 1.462118 \\
\hline & -0.578798 & 6.047705 & 0.756369 \\
\hline & -0.105934 & 4.357650 & 0.561835 \\
\hline & -5.548702 & 0.427202 & -4.819955 \\
\hline & -5.348809 & -0.097220 & -3.148325 \\
\hline & -3.932549 & 0.006379 & -4.206079 \\
\hline & -4.836384 & 2.523952 & -5.644640 \\
\hline
\end{tabular}




\begin{tabular}{|c|c|c|c|}
\hline & -3.164533 & 2.491734 & -5.026853 \\
\hline & -4.242306 & 3.824537 & -4.614750 \\
\hline & -5.960403 & 3.571437 & -2.797367 \\
\hline & -6.423358 & 1.961582 & -2.221063 \\
\hline & -6.785689 & 2.443600 & -3.892084 \\
\hline & -2.043681 & -1.595781 & 2.913237 \\
\hline & -4.761722 & 0.143335 & 0.124392 \\
\hline & -2.341231 & -3.414684 & 5.951911 \\
\hline & -1.903314 & -1.902965 & 5.146755 \\
\hline & -1.938037 & -3.422721 & 4.229556 \\
\hline & -5.620926 & -1.678602 & 5.736191 \\
\hline & -4.074338 & -0.843862 & 5.958337 \\
\hline & -4.398413 & -2.363947 & 6.817778 \\
\hline & -5.686821 & -3.910030 & 4.423236 \\
\hline & -4.471648 & -4.568504 & 5.529168 \\
\hline & -4.182123 & -4.585323 & 3.777355 \\
\hline & -6.525570 & 1.484460 & 0.555197 \\
\hline & -7.091771 & 1.487724 & 2.231855 \\
\hline & -8.254324 & 1.309992 & 0.900371 \\
\hline & -9.180917 & -0.772249 & 1.858179 \\
\hline & -8.108306 & -0.626872 & 3.255972 \\
\hline & -8.152591 & -2.136030 & 2.317398 \\
\hline & -7.215312 & -2.179454 & -0.076069 \\
\hline & -6.612067 & -0.689330 & -0.818733 \\
\hline & -8.335189 & -0.851962 & -0.449555 \\
\hline & 1.266225 & -2.419256 & 1.030413 \\
\hline & 3.457728 & -0.644285 & -2.163775 \\
\hline & 6.456085 & -2.442020 & -1.887047 \\
\hline & 5.737204 & -0.991263 & -2.605903 \\
\hline & 6.701187 & -2.087034 & -3.609733 \\
\hline & 5.822630 & -4.304546 & -4.305646 \\
\hline & 4.280112 & -4.929417 & -3.707629 \\
\hline & 5.663524 & -4.760828 & -2.605856 \\
\hline & 4.772692 & -2.296799 & -5.240707 \\
\hline & 3.763164 & -1.221723 & -4.261501 \\
\hline & 3.171510 & -2.826484 & -4.691207 \\
\hline & 3.077251 & -6.486361 & 1.972905 \\
\hline
\end{tabular}




\begin{tabular}{|c|c|c|c|}
\hline $\mathrm{H}$ & 3.678102 & -4.820637 & 2620 \\
\hline $\mathrm{H}$ & 4.139371 & -5.816492 & 0.721209 \\
\hline & 0.059215 & -4.409774 & 1.172356 \\
\hline & 1.264507 & -4.085203 & 2.433253 \\
\hline $\mathrm{H}$ & 0.689001 & -5.735570 & 2.169352 \\
\hline $\mathrm{H}$ & 7.862528 & 2.749178 & 1.328115 \\
\hline $\mathrm{H}$ & 8.613308 & 1.408609 & 2.202371 \\
\hline & 7.292886 & 2.312671 & 5028 \\
\hline & 4.476180 & -0.302306 & 0.361249 \\
\hline $\mathrm{H}$ & 1.746044 & 2.978139 & 0.516102 \\
\hline $\mathrm{H}$ & 7.456448 & -0.717718 & 2.607821 \\
\hline & 5.828762 & 1440 & 1.986616 \\
\hline & 6.054772 & 0.100992 & 3.327596 \\
\hline $\mathrm{H}$ & 2.778685 & 4.568845 & 3.453521 \\
\hline $\mathrm{H}$ & 1.474252 & 4.415253 & 2.272136 \\
\hline & 2.083053 & 6.023470 & 2.707078 \\
\hline $\mathrm{H}$ & 2.629691 & 6.623027 & 0.313529 \\
\hline $\mathrm{H}$ & 1.968817 & 5.077698 & -0.231828 \\
\hline $\mathrm{H}$ & 3.618973 & 5.535882 & -0.683441 \\
\hline $\mathrm{H}$ & 7.399916 & 1.176921 & -0.651001 \\
\hline $\mathrm{H}$ & 6.630176 & -0.393555 & -0.371336 \\
\hline $\mathrm{H}$ & 8.251504 & -0.082881 & 0.267103 \\
\hline $\mathrm{H}$ & 0.741295 & -5.815488 & -0.917407 \\
\hline 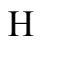 & 1.281924 & -7.053645 & 0.235537 \\
\hline $\mathrm{H}$ & 2.379742 & -6.474925 & -1.019590 \\
\hline $\mathrm{H}$ & 4.378486 & 6.756871 & 2.025993 \\
\hline $\mathrm{H}$ & 5.454535 & 5.702391 & 1.097363 \\
\hline 11 & 5.074952 & 5.326254 & 2.793287 \\
\hline $\mathrm{Cu}$ & 0.075651 & 0.206466 & 1.632088 \\
\hline $\mathrm{H}$ & 0.125463 & 1.616263 & 2.427699 \\
\hline $\mathrm{C}$ & 0.644814 & 0.594053 & 3.643100 \\
\hline $\mathrm{C}$ & 0.748959 & -0.796332 & 3.309578 \\
\hline $\mathrm{H}$ & 0.029270 & -1.489709 & 3.739757 \\
\hline $\mathrm{C}$ & -0.475653 & 0.981132 & 4.596819 \\
\hline 11 & -1.420248 & 0.517556 & 4.294962 \\
\hline $\mathrm{H}$ & -0.623897 & 2.065807 & 4.624140 \\
\hline $\mathrm{H}$ & 1.743211 & -1.208972 & 3.144233 \\
\hline
\end{tabular}




$\begin{array}{lrrr}\mathrm{C} & 1.946831 & 1.367394 & 3.828639 \\ \mathrm{H} & 2.592627 & 1.191441 & 2.962178 \\ \mathrm{H} & 1.728992 & 2.442441 & 3.836200 \\ \mathrm{H} & 3.757959 & -4.860962 & -1.466732 \\ \mathrm{H} & 5.804987 & 3.518923 & 1.750924 \\ \mathrm{H} & -6.269694 & -1.891351 & 3.570742 \\ \mathrm{H} & -3.521889 & 4.223102 & -2.639989 \\ \mathrm{H} & -0.234597 & 0.633424 & 5.610488 \\ \mathrm{C} & 2.731286 & 1.001137 & 5.092023 \\ \mathrm{H} & 2.111400 & 1.150948 & 5.985561 \\ \mathrm{H} & 2.988776 & -0.064364 & 5.065252 \\ \mathrm{C} & 4.003442 & 1.842239 & 5.205279 \\ \mathrm{H} & 3.760923 & 2.906522 & 5.315104 \\ \mathrm{H} & 4.612030 & 1.546454 & 6.066886 \\ \mathrm{H} & 4.615950 & 1.741222 & 4.300424\end{array}$

\section{TS-2A}

wB97XD SCF energy: $\quad-6150.61861793$ a.u.

wB97XD enthalpy: $\quad-6148.939356$ a.u.

wB97XD free energy: $\quad-6149.198951$ a.u.

wB97XD SCF energy in solution: $\quad-7595.26147736$ a.u.

wB97XD enthalpy in solution: $\quad-7593.582215$ a.u.

wB97XD free energy in solution: $\quad-7593.841810$ a.u.

wB97XD free energy in solution after quasi-harmonic correction: -7593.814546 a.u.

Imaginary frequency: $\quad-791.1072 \mathrm{~cm}-1$

Cartesian coordinates

\begin{tabular}{lrrr}
\multicolumn{2}{l}{ ATOM X } & Y & \multicolumn{2}{l}{ X } \\
P & 1.873513 & -0.265640 & -0.381830 \\
P & -1.515950 & 0.344443 & -0.044512 \\
O & 1.662112 & 1.772423 & 3.890576 \\
O & 1.002803 & 3.964165 & 3.950622 \\
O & -0.485381 & -0.669696 & 4.333405 \\
O & 0.272410 & -2.795264 & 4.753917 \\
C & -0.856847 & 1.516995 & 1.209125 \\
C & 0.168568 & 1.047191 & 2.074020
\end{tabular}



$\begin{array}{llll}\text { C } & 0.686611 & 1.973993 & 2.953145\end{array}$
$\begin{array}{llll}\text { C } & 0.284215 & 3.301527 & 2.992655\end{array}$
$\begin{array}{llll}\text { C } & -0.698596 & 3.774382 & 2.158862\end{array}$
$\begin{array}{llll}\text { C } & -1.264561 & 2.849337 & 1.267977\end{array}$
$\begin{array}{llll}\text { C } & 1.613256 & 2.929445 & 4.710397\end{array}$
$\begin{array}{llll}\text { C } & 1.551672 & -1.006350 & 1.273502\end{array}$
$\begin{array}{llll}\text { C } & 2.023887 & -2.286969 & 1.561031\end{array}$
$\begin{array}{llll}\text { C } & 1.655802 & -2.988794 & 2.717504\end{array}$
$\begin{array}{llll}\text { C } & 0.781227 & -2.357621 & 3.565399\end{array}$
C $\quad 0.320492 \quad-1.073839 \quad 3.305295$
$\begin{array}{llll}\text { C } & 0.669927 & -0.354765 & 2.180745\end{array}$
$\begin{array}{llll}\text { C } & -0.727154 & -1.844418 & 5.094979\end{array}$
$\begin{array}{llll}\text { C } & -2.180856 & -1.006021 & 0.993764\end{array}$
$\begin{array}{llll}\text { C } & -2.987868 & -0.769974 & 2.108507\end{array}$
$\begin{array}{llll}\text { C } & -3.542161 & -1.824733 & 2.840424\end{array}$
$\begin{array}{llll}\text { C } & -3.237748 & -3.134542 & 2.430788\end{array}$
$\begin{array}{llll}\text { C } & -2.411423 & -3.408442 & 1.335103\end{array}$
$\begin{array}{llll}\text { C } & -1.892125 & -2.317322 & 0.627128\end{array}$
$\begin{array}{llll}\text { C } & -0.180565 & -5.516491 & 1.102168\end{array}$
$\begin{array}{llll}\text { C } & -3.107046 & -6.396650 & 1.579899\end{array}$
$\begin{array}{llll}\text { C } & -2.236718 & -5.173798 & -1.140118\end{array}$
$\begin{array}{llll}\text { C } & -6.429795 & -1.110639 & 3.595636\end{array}$
$\begin{array}{llll}\text { C } & -4.071773 & 0.102909 & 5.155693\end{array}$
$\begin{array}{llll}\text { C } & -4.754228 & -2.904960 & 5.461703\end{array}$
$\begin{array}{llll}\text { C } & -3.013907 & 1.119414 & -0.749516\end{array}$
$\begin{array}{llll}\text { C } & -2.862494 & 2.227485 & -1.588966\end{array}$
C $\quad-4.274841 \quad 0.530115 \quad-0.642066$
$\begin{array}{llll}\text { C } & -5.383020 & 1.032480 & -1.332326\end{array}$
$\begin{array}{llll}\text { C } & -5.193439 & 2.163432 & -2.137716\end{array}$
$\begin{array}{llll}\text { C } & -3.944070 & 2.781286 & -2.282878\end{array}$
$\begin{array}{llll}\text { C } & -2.801304 & 5.614845 & -2.400775\end{array}$
$\begin{array}{llll}\text { C } & -2.564177 & 3.753132 & -4.848544\end{array}$
$\begin{array}{lllll}\text { C } & -5.315861 & 4.896959 & -4.047333\end{array}$
$\begin{array}{llll}\text { C } & -6.790790 & -1.540134 & -0.444642\end{array}$
$\begin{array}{llll}\text { C } & -7.850809 & 0.051363 & -2.871846\end{array}$
$\begin{array}{llll}\text { C } & -8.164804 & 1.191285 & -0.023491\end{array}$
$\begin{array}{llll}\text { C } & 2.562142 & 1.383473 & -0.002818\end{array}$ 


$$
\begin{aligned}
& \begin{array}{llll}
\text { C } & 2.077867 & 2.447200 & -0.765116
\end{array} \\
& \begin{array}{llll}
\text { C } & 2.458970 & 3.767582 & -0.508189
\end{array} \\
& \begin{array}{llll}
\text { C } & 3.368514 & 3.983515 & 0.534352
\end{array} \\
& \begin{array}{llll}
\text { C } & 3.888338 & 2.941392 & 1.316598
\end{array} \\
& \begin{array}{llll}
\text { C } & 3.455998 & 1.639623 & 1.038767
\end{array} \\
& \begin{array}{llll}
\text { C } & 6.834189 & 3.554476 & 1.991977
\end{array} \\
& \text { C } \quad 4.562676 \quad 4.884377 \quad 3.574672 \\
& \begin{array}{llll}
\text { C } & 5.142699 & 1.829132 & 3.886071
\end{array} \\
& \begin{array}{llll}
\text { C } & 3.068546 & 6.338334 & -2.085237
\end{array} \\
& \begin{array}{llll}
\text { C } & 0.774620 & 4.459369 & -2.970693
\end{array} \\
& \begin{array}{llll}
\text { C } & 5.190031 & -2.988593 & -2.038416
\end{array} \\
& \begin{array}{llll}
\text { C } & 5.596069 & -1.854405 & -1.318149
\end{array} \\
& \begin{array}{llll}
\text { C } & 8.201551 & -2.961315 & -0.131543
\end{array} \\
& \begin{array}{llll}
\text { C } & 4.600700 & -1.005664 & -0.821169
\end{array} \\
& \begin{array}{lllll}
\text { C } & 3.248805 & -1.269465 & -1.040207
\end{array} \\
& \begin{array}{llll}
\text { C } & 2.887036 & -2.394778 & -1.783538
\end{array} \\
& \begin{array}{llll}
\text { C } & 3.843309 & -3.282608 & -2.289100
\end{array} \\
& \begin{array}{llll}
\text { C } & 8.287226 & -1.197157 & -2.654133
\end{array} \\
& \begin{array}{llll}
\text { C } & 3.144009 & -4.347240 & -5.097307
\end{array} \\
& \begin{array}{llll}
\text { C } & 1.581202 & -5.314458 & -2.624046
\end{array} \\
& \begin{array}{llll}
\text { C } & 7.554054 & 0.052784 & 0.074301
\end{array} \\
& \begin{array}{llll}
\text { C } & 0.501531 & 6.130908 & -0.396676
\end{array} \\
& \begin{array}{llll}
\text { C } & 4.521092 & -6.184835 & -3.039286
\end{array} \\
& \mathrm{H} \quad-1.028316 \quad 4.806127 \quad 2.193609 \\
& \mathrm{H} \quad-2.061876 \quad 3.191561 \quad 0.617304 \\
& \mathrm{H} \quad 2.627208 \quad 3.224290 \quad 4.981075 \\
& \mathrm{H} \quad 1.000814 \quad 2.719496 \quad 5.599232 \\
& \mathrm{H} \quad 2.696287 \quad-2.773937 \quad 0.863838 \\
& \text { H } \quad 2.034497 \quad-3.983004 \quad 2.922819 \\
& \mathrm{H} \quad-1.714396 \quad-2.247234 \quad 4.832870 \\
& \mathrm{H} \quad-0.656714 \quad-1.607209 \quad 6.158040 \\
& \mathrm{H} \quad-3.189216 \quad 0.259925 \quad 2.398880 \\
& \mathrm{H} \quad-1.242985 \quad-2.471192 \quad-0.234442 \\
& \text { H } \quad 0.463364 \quad-4.749728 \quad 0.656014 \\
& \text { H } \quad 0.113985-6.490415 \quad 0.693191 \\
& \mathrm{H} \quad 0.010858 \quad-5.524111 \quad 2.180888 \\
& \text { H } \quad-2.949843 \quad-6.403591 \quad 2.664876
\end{aligned}
$$




$$
\begin{aligned}
& \mathrm{H} \quad-2.904300 \quad-7.408893 \quad 1.211828 \\
& \text { H } \quad-4.165153 \quad-6.179861 \quad 1.393828 \\
& \text { H } \quad-3.269036 \quad-4.928333-1.414402 \\
& \text { H } \quad-1.996961 \quad-6.159285-1.556334 \\
& \mathrm{H} \quad-1.583532-4.440054-1.627635 \\
& \mathrm{H} \quad-7.133070 \quad-0.846453 \quad 4.394043 \\
& \mathrm{H} \quad-6.825795 \quad-1.989170 \quad 3.073660 \\
& \mathrm{H} \quad-6.408690 \quad-0.280593 \quad 2.879050 \\
& \mathrm{H} \quad-4.600624 \quad 0.260051 \quad 6.102750 \\
& \mathrm{H} \quad-4.226313 \quad 0.997331 \quad 4.541138 \\
& \mathrm{H} \quad-2.998610 \quad 0.040191 \quad 5.366320 \\
& \mathrm{H} \quad-3.763245 \quad-3.143196 \quad 5.864981 \\
& \mathrm{H} \quad-5.138815 \quad-3.806912 \quad 4.971919 \\
& \text { H } \quad-5.413686 \quad-2.686735 \quad 6.309665 \\
& \mathrm{H} \quad-1.865795 \quad 2.647722-1.718048 \\
& \mathrm{H} \quad-4.390615 \quad-0.355390 \quad-0.025879 \\
& \mathrm{H} \quad-2.553772 \quad 6.481174 \quad-3.025614 \\
& \mathrm{H} \quad-1.865535 \quad 5.245989-1.966470 \\
& \text { H } \quad-3.437335 \quad 5.962041 \quad-1.578638 \\
& \mathrm{H} \quad-3.029552 \quad 2.944012 \quad-5.422656 \\
& \mathrm{H} \quad-1.588935 \quad 3.391981 \quad-4.504008 \\
& \mathrm{H} \quad-2.385977 \quad 4.593702 \quad-5.529916 \\
& \mathrm{H} \quad-5.822514 \quad 4.142382 \quad-4.660021 \\
& \mathrm{H} \quad-5.172381 \quad 5.785776 \quad-4.672478 \\
& \mathrm{H} \quad-5.987894 \quad 5.172539 \quad-3.226564 \\
& \mathrm{H} \quad-6.370473 \quad-1.499161 \quad 0.566952 \\
& \text { H } \quad-6.104905 \quad-2.127006-1.066173 \\
& \mathrm{H} \quad-7.740766 \quad-2.083930-0.385168 \\
& \text { H } \quad-8.833959 \quad-0.429778-2.811705 \\
& \text { H } \quad-7.226377 \quad-0.541051 \quad-3.549992 \\
& \mathrm{H} \quad-7.993471 \quad 1.038652-3.326295 \\
& \text { H } \quad-8.303462 \quad 2.209215 \quad-0.405528 \\
& \mathrm{H} \quad-7.726443 \quad 1.268866 \quad 0.978078 \\
& \mathrm{H} \quad-9.155255 \quad 0.7323690 .078065 \\
& \mathrm{H} \quad 1.362681 \quad 2.219456 \quad-1.553289 \\
& \text { H } \quad 3.790061 \quad 0.813473 \quad 1.664031 \\
& \begin{array}{llll}
\mathrm{H} & 6.841256 & 4.368077 & 1.257539
\end{array}
\end{aligned}
$$




\begin{tabular}{|c|c|c|c|}
\hline & 7.189614 & 2.647559 & 1.489433 \\
\hline & 7.554028 & 3.806896 & 2.779792 \\
\hline & 5.046099 & 4.993112 & 4.552642 \\
\hline & 3.476851 & 4.919783 & 3.716688 \\
\hline & 4.837446 & 5.762577 & 2.978243 \\
\hline & 5.679174 & 2.077710 & 4.809079 \\
\hline & 5.661455 & 0.978665 & 3.427367 \\
\hline & 4.134422 & 1.491533 & 4.147978 \\
\hline & 2.654607 & 7.182167 & -2.649446 \\
\hline & 3.776764 & 5.812498 & -2.735091 \\
\hline & 3.633551 & 6.750272 & -1.240863 \\
\hline & 0.003539 & 3.750304 & -2.647090 \\
\hline & 1.446642 & 3.916410 & -3.644851 \\
\hline & 0.278134 & 5.247599 & -3.548405 \\
\hline & 7.726002 & -3.139978 & 0.839283 \\
\hline & 9.271587 & -2.797401 & 0.041353 \\
\hline & 8.097084 & -3.876703 & -0.725576 \\
\hline & 4.880557 & -0.120506 & -0.257167 \\
\hline & 1.825563 & -2.572424 & -1.952492 \\
\hline & 9.356832 & -1.004248 & -2.510802 \\
\hline & 7.855753 & -0.337937 & -3.179439 \\
\hline & 8.190231 & -2.069853 & -3.310324 \\
\hline & 4.108012 & -4.006658 & -5.491865 \\
\hline & 2.416557 & -3.542573 & -5.252380 \\
\hline & 2.822124 & -5.210810 & -5.691352 \\
\hline & 1.219978 & -6.204294 & -3.152788 \\
\hline & 0.835045 & -4.523160 & -2.764478 \\
\hline & 1.616161 & -5.549520 & -1.554016 \\
\hline & 7.053448 & -0.090205 & 1.039570 \\
\hline & 7.101483 & 0.925104 & -0.411849 \\
\hline & 8.604228 & 0.292606 & 0.276829 \\
\hline & -0.315449 & 5.476773 & -0.073955 \\
\hline & 0.063100 & 6.986131 & -0.924109 \\
\hline & 1.001128 & 6.504385 & 0.504876 \\
\hline & 4.192881 & -7.088947 & -3.565044 \\
\hline & 4.643288 & -6.437738 & -1.980131 \\
\hline & 5.507135 & -5.915820 & -3.435679 \\
\hline
\end{tabular}




$$
\begin{array}{lrrr}
\mathrm{Cu} & 0.005518 & -0.249759 & -1.602881 \\
\mathrm{H} & -0.434714 & -1.662981 & -2.253599 \\
\mathrm{C} & -0.578300 & -0.686908 & -3.595414 \\
\mathrm{C} & -0.069042 & 0.647663 & -3.456142 \\
\mathrm{H} & -0.782364 & 1.467556 & -3.486317 \\
\mathrm{C} & -2.091362 & -0.797569 & -3.787091 \\
\mathrm{H} & -2.268973 & -0.746937 & -4.873307 \\
\mathrm{H} & -2.565105 & 0.094069 & -3.359353 \\
\mathrm{H} & 0.918675 & 0.870640 & -3.856607 \\
\mathrm{C} & 0.250137 & -1.646092 & -4.438039 \\
\mathrm{H} & 1.309868 & -1.567598 & -4.175227 \\
\mathrm{H} & -0.058913 & -2.689039 & -4.306873 \\
\mathrm{H} & 3.674977 & 5.005907 & 0.759209 \\
\mathrm{H} & -6.044201 & 2.569168 & -2.684111 \\
\mathrm{H} & -3.662012 & -3.968898 & 2.988319 \\
\mathrm{H} & 5.953796 & -3.668780 & -2.416888 \\
\mathrm{H} & 0.141893 & -1.379990 & -5.498658 \\
\mathrm{C} & -2.797411 & -2.030193 & -3.225385 \\
\mathrm{H} & -2.689095 & -2.036540 & -2.134948 \\
\mathrm{H} & -2.313892 & -2.946794 & -3.588170 \\
\mathrm{C} & -4.282035 & -2.048348 & -3.585466 \\
\mathrm{H} & -4.787967 & -2.917154 & -3.148745 \\
\mathrm{H} & -4.775547 & -1.143498 & -3.209688 \\
\mathrm{H} & -4.432454 & -2.083843 & -4.671299 \\
\mathrm{Si} & 3.273223 & -4.790128 & -3.270404 \\
\mathrm{Si} & 7.418346 & -1.486624 & -1.006989 \\
\mathrm{Si} & -1.988272 & -5.142086 & 0.727324 \\
\mathrm{Si} & -7.057498 & 0.179730 & -1.167146 \\
\mathrm{Si} & -3.658863 & 4.269347 & -3.406006 \\
\mathrm{Si} & -4.701411 & -1.441041 & 4.274082 \\
\mathrm{Si} & 1.701300 & 5.180785 & -1.497690 \\
\mathrm{Si} & 5.107356 & 3.297966 & 2.705025
\end{array}
$$




\section{TS-2B}

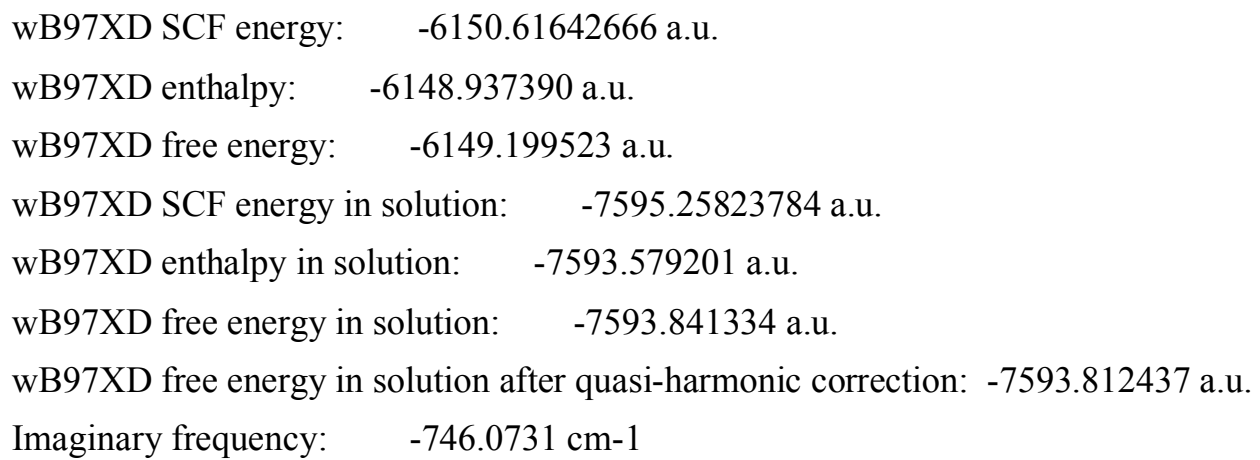

Cartesian coordinates

\begin{tabular}{lrcr} 
ATOM & X & Y & \multicolumn{2}{l}{ Z } \\
P & -1.645863 & 0.017661 & -0.264216 \\
P & 1.809432 & -0.107663 & -0.356986 \\
O & -0.766495 & -2.331348 & 3.698802 \\
O & 0.247497 & -4.380408 & 3.475029 \\
O & 0.961989 & 0.303966 & 4.314095 \\
O & 0.050060 & 2.298719 & 4.970148 \\
C & 1.464513 & -1.401128 & 0.909857 \\
C & 0.443935 & -1.193111 & 1.880352 \\
C & 0.134690 & -2.280306 & 2.672514 \\
C & 0.749534 & -3.518223 & 2.544007 \\
C & 1.740927 & -3.734751 & 1.620075 \\
C & 2.083997 & -2.646257 & 0.805659 \\
C & -0.868034 & -3.705560 & 4.043219 \\
C & -1.208014 & 0.754355 & 1.366596 \\
C & -1.765505 & 1.962221 & 1.783048 \\
C & -1.409208 & 2.584697 & 2.988876 \\
C & -0.484366 & 1.932035 & 3.765023 \\
C & 0.067689 & 0.722317 & 3.366511 \\
C & -0.236052 & 0.102413 & 2.173568 \\
C & 0.699712 & 1.125422 & 5.440380 \\
C & 2.138925 & 1.392258 & 0.636298 \\
C & 2.898827 & 1.378510 & 1.810486 \\
C & 3.138160 & 2.548826 & 2.533704 \\
C & 2.555248 & 3.737714 & 2.063981 \\
C & 1.767504 & 3.786509 & 0.910611
\end{tabular}



$\begin{array}{llll}\text { C } & 1.581105 & 2.591844 & 0.201838\end{array}$
$\begin{array}{lllll}\text { C } & -0.925485 & 5.187497 & 0.403681\end{array}$
$\begin{array}{llll}\text { C } & 1.520345 & 6.832700 & 1.296187\end{array}$
$\begin{array}{lllll}\text { C } & 1.441315 & 5.582377 & -1.533504\end{array}$
$\begin{array}{llll}\text { C } & 5.937990 & 3.198514 & 3.613851\end{array}$
$\begin{array}{llll}\text { C } & 4.395389 & 0.777259 & 4.704379\end{array}$
$\begin{array}{llll}\text { C } & 3.448645 & 3.681618 & 5.357180\end{array}$
$\begin{array}{llll}\text { C } & 3.446775 & -0.575773 & -1.030929\end{array}$
$\begin{array}{lllll}\text { C } & 3.468297 & -1.485998 & -2.094952\end{array}$
$\begin{array}{lllll}\text { C } & 4.654668 & -0.070091 & -0.558461\end{array}$
$\begin{array}{llll}\text { C } & 5.883252 & -0.466505 & -1.103178\end{array}$
$\begin{array}{llll}\text { C } & 5.862651 & -1.390997 & -2.151767\end{array}$
$\begin{array}{llll}\text { C } & 4.667240 & -1.915049 & -2.670580\end{array}$
$\begin{array}{llll}\text { C } & 2.913877 & -3.555936 & -4.593060\end{array}$
$\begin{array}{llll}\text { C } & 5.597332 & -2.369202 & -5.555665\end{array}$
$\begin{array}{lllll}\text { C } & 5.583746 & -4.706329 & -3.548389\end{array}$
$\begin{array}{llll}\text { C } & 7.374728 & 2.141510 & -0.509766\end{array}$
$\begin{array}{lllll}\text { C } & 8.965976 & -0.417124 & -1.244111\end{array}$
$\begin{array}{llll}\text { C } & 7.492894 & -0.190494 & 1.473859\end{array}$
$\begin{array}{llll}\text { C } & -2.249718 & -1.630320 & 0.260540\end{array}$
C $\quad-1.712192-2.748945 \quad-0.377419$
$\begin{array}{llll}\text { C } & -2.037435 & -4.047605 & 0.025663\end{array}$
$\begin{array}{llll}\text { C } & -2.964562 & -4.191019 & 1.067523\end{array}$
$\begin{array}{llll}\text { C } & -3.529062 & -3.093865 & 1.733943\end{array}$
$\begin{array}{llll}\text { C } & -3.124526 & -1.815184 & 1.332238\end{array}$
$\begin{array}{lllll}\text { C } & -6.516316 & -2.939833 & 2.434213\end{array}$
$\begin{array}{llll}\text { C } & -4.729458 & -5.006884 & 3.841421\end{array}$
$\begin{array}{llll}\text { C } & -4.388091 & -1.984794 & 4.447628\end{array}$
$\begin{array}{llll}\text { C } & -0.618110 & -6.686636 & 0.607659\end{array}$
$\begin{array}{llll}\text { C } & -2.401064 & -6.441360 & -1.886875\end{array}$
C $\quad-5.250006 \quad 2.555969-1.625190$
$\begin{array}{llll}\text { C } & -5.522740 & 1.397563 & -0.891497\end{array}$
$\begin{array}{lllll}\text { C } & -8.540734 & 1.961902 & -1.204819\end{array}$
$\begin{array}{lllll}\text { C } & -4.435404 & 0.613073 & -0.483103\end{array}$
$\begin{array}{llll}\text { C } & -3.122917 & 0.967971 & -0.784346\end{array}$
$\begin{array}{lllll}\text { C } & -2.893840 & 2.126879 & -1.538465\end{array}$
C $\quad-3.944233 \quad 2.941523 \quad-1.968389$ 


\begin{tabular}{|c|c|c|c|}
\hline$\gamma$ & -7.501696 & -0.938277 & -0.908318 \\
\hline$C$ & -4.526240 & 4.268024 & -4.659840 \\
\hline & -1.795565 & 4.724986 & -3.286121 \\
\hline & -7.384961 & 0.988847 & 1.491786 \\
\hline & 0.276159 & -4.912141 & -1.785530 \\
\hline & -4.346823 & 5.975330 & -2.096493 \\
\hline & 2.237296 & -4.693952 & 1.527283 \\
\hline & 2.863401 & -2.791506 & 0.065939 \\
\hline & -1.792324 & -4.117149 & 3.620156 \\
\hline & -0.839994 & -3.808937 & 5.129810 \\
\hline & -2.511139 & 2.445320 & 1.161465 \\
\hline & -1.850699 & 3.525869 & 3.295185 \\
\hline & 1.641593 & 1.396529 & 5.918029 \\
\hline & 0.032923 & 0.591582 & 6.132942 \\
\hline & 3.291115 & 0.429406 & 2.171938 \\
\hline & 0.972867 & 2.572815 & -0.702546 \\
\hline & -1.275497 & 4.265886 & -0.075619 \\
\hline & -1.433381 & 6.033462 & -0.075435 \\
\hline & -1.240045 & 5.152216 & 1.452320 \\
\hline & 1.235127 & 6.725084 & 2.349178 \\
\hline & 1.067352 & 7.758950 & 0.924348 \\
\hline & 2.608724 & 6.954187 & 1.252174 \\
\hline & 2.521712 & 5.742184 & -1.624420 \\
\hline & 0.931826 & 6.441307 & -1.985807 \\
\hline & 1.186615 & 4.695660 & -2.125846 \\
\hline & 6.598447 & 3.228957 & 4.488579 \\
\hline & 5.875797 & 4.213127 & 3.203816 \\
\hline & 6.413263 & 2.563268 & 2.857011 \\
\hline & 4.836094 & 0.762153 & 5.707947 \\
\hline & 5.053254 & 0.189683 & 4.052619 \\
\hline & 3.429789 & 0.261815 & 4.739722 \\
\hline & 2.365909 & 3.530041 & 5.429128 \\
\hline & 3.608529 & 4.732822 & 5.089254 \\
\hline & 3.889582 & 3.528063 & 6.348994 \\
\hline & 2.517651 & -1.858505 & -2.470393 \\
\hline & 4.643577 & 0.658645 & 0.246994 \\
\hline & 2.903043 & -4.286667 & -5.410168 \\
\hline
\end{tabular}




\begin{tabular}{|c|c|c|c|}
\hline 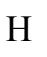 & 2.375668 & -2.665265 & -4.937635 \\
\hline & 2.347032 & -3.984919 & -3.758024 \\
\hline & 6.621903 & -2.092053 & -5.281647 \\
\hline & 5.087326 & -1.461480 & -5.897117 \\
\hline & 5.654957 & -3.063140 & -6.402356 \\
\hline & 6.603776 & -4.480271 & -3.216498 \\
\hline & 5.652080 & -5.434334 & -4.365213 \\
\hline & 5.060894 & -5.185490 & -2.712961 \\
\hline & 6.475486 & 2.536631 & -0.021871 \\
\hline & 7.346289 & 2.455372 & -1.559037 \\
\hline & 8.244135 & 2.614060 & -0.037664 \\
\hline & 9.885349 & -0.002976 & -0.814782 \\
\hline & 8.953612 & -0.161905 & -2.309966 \\
\hline & 9.022903 & -1.508441 & -1.159563 \\
\hline & 7.559148 & -1.274777 & 1.616409 \\
\hline & 6.579953 & 0.153603 & 1.975735 \\
\hline & 8.346298 & 0.272230 & 1.983191 \\
\hline & -0.992047 & -2.580443 & -1.175299 \\
\hline & -3.476257 & -0.942789 & 1.880618 \\
\hline & -6.768794 & -3.657006 & 1.644952 \\
\hline & -6.583761 & -1.935400 & 2.000679 \\
\hline & -7.279805 & -3.015726 & 3.217396 \\
\hline & -5.464699 & -5.108987 & 4.648085 \\
\hline & -3.746527 & -5.253978 & 4.258259 \\
\hline & -4.969098 & -5.762158 & 3.084116 \\
\hline & -4.977715 & -2.154465 & 5.355808 \\
\hline & -4.610714 & -0.970173 & 4.096722 \\
\hline & -3.325715 & -2.006658 & 4.714200 \\
\hline & 0.006157 & -7.497478 & 0.214530 \\
\hline & -1.476582 & -7.148113 & 1.110498 \\
\hline & -0.043568 & -6.148672 & 1.369293 \\
\hline & -2.747951 & -5.793225 & -2.699452 \\
\hline & -3.282279 & -6.772554 & -1.325206 \\
\hline & -1.938123 & -7.327577 & -2.336772 \\
\hline & -8.426162 & 3.007895 & -0.897918 \\
\hline & -9.553474 & 1.646260 & -0.929255 \\
\hline & -8.465349 & 1.920969 & -2.297415 \\
\hline
\end{tabular}




$$
\begin{array}{lrrr}
\mathrm{H} & -4.623234 & -0.301887 & 0.071382 \\
\mathrm{H} & -1.866042 & 2.369095 & -1.806424 \\
\mathrm{H} & -8.462523 & -1.326653 & -0.550783 \\
\mathrm{H} & -6.713279 & -1.585072 & -0.505925 \\
\mathrm{H} & -7.481828 & -1.034999 & -1.999592 \\
\mathrm{H} & -5.602037 & 4.112939 & -4.516986 \\
\mathrm{H} & -4.134525 & 3.397563 & -5.197785 \\
\mathrm{H} & -4.397499 & 5.148524 & -5.300129 \\
\mathrm{H} & -1.616298 & 5.563463 & -3.969345 \\
\mathrm{H} & -1.323816 & 3.835395 & -3.717631 \\
\mathrm{H} & -1.279554 & 4.947899 & -2.347121 \\
\mathrm{H} & -7.333542 & 2.034477 & 1.815758 \\
\mathrm{H} & -6.561642 & 0.454187 & 1.980770 \\
\mathrm{H} & -8.325578 & 0.564916 & 1.862206 \\
\mathrm{H} & -0.056677 & -4.291865 & -2.626284 \\
\mathrm{H} & 0.847273 & -5.753239 & -2.196354 \\
\mathrm{H} & 0.951644 & -4.303186 & -1.174102 \\
\mathrm{H} & -4.211754 & 6.896340 & -2.675611 \\
\mathrm{H} & -3.848814 & 6.107916 & -1.129147 \\
\mathrm{H} & -5.419607 & 5.856471 & -1.904844 \\
\mathrm{Cu} & 0.056854 & 0.026035 & -1.754549 \\
\mathrm{H} & 0.088717 & 1.323960 & -2.727638 \\
\mathrm{C} & -0.070670 & 0.127233 & -3.876875 \\
\mathrm{C} & -0.184009 & -1.215583 & -3.389926 \\
\mathrm{H} & 0.646396 & -1.898721 & -3.549691 \\
\mathrm{C} & 1.223709 & 0.485968 & -4.592306 \\
\mathrm{H} & 2.091857 & 0.141878 & -4.022083 \\
\mathrm{H} & 1.318190 & 1.567800 & -4.734082 \\
\mathrm{Si} & -3.640296 & 4.484005 & -3.010489 \\
\mathrm{Si} & -7.254809 & 0.855827 & -0.386403 \\
\mathrm{Si} & -4.790919 & -3.264241 & 3.121908 \\
\mathrm{Si} & -1.185628 & -5.529429 & -0.769581 \\
\mathrm{H} & 7.682808 & -3.144042 & -4.100889 \\
\mathrm{H} & 0.949087 & 5.357827 & 0.271426 \\
\mathrm{H} & 0.264818 & -0.357037 \\
\mathrm{H} & -169280 & -1.679493 & -3.398583
\end{array}
$$




$\begin{array}{lrrr}\mathrm{C} & -1.329739 & 0.749057 & -4.474050 \\ \mathrm{H} & -2.161343 & 0.618840 & -3.770734 \\ \mathrm{H} & -1.184967 & 1.831489 & -4.588783 \\ \mathrm{H} & -3.237727 & -5.195660 & 1.391572 \\ \mathrm{H} & 6.809652 & -1.711121 & -2.586815 \\ \mathrm{H} & 2.716397 & 4.656334 & 2.627680 \\ \mathrm{H} & -6.084343 & 3.176777 & -1.952311 \\ \mathrm{H} & 1.250303 & -0.001065 & -5.576370 \\ \mathrm{C} & -1.725938 & 0.150336 & -5.828313 \\ \mathrm{H} & -0.899452 & 0.258058 & -6.542345 \\ \mathrm{H} & -1.898554 & -0.925854 & -5.711943 \\ \mathrm{C} & -2.975938 & 0.820498 & -6.397062 \\ \mathrm{H} & -2.800187 & 1.888450 & -6.575856 \\ \mathrm{H} & -3.278789 & 0.369052 & -7.347994 \\ \mathrm{H} & -3.818009 & 0.734587 & -5.699403\end{array}$

\section{TS-3A}

wB97XD SCF energy: $\quad-20432.77877740$ a.u.

wB97XD enthalpy: $\quad-20431.103229$ a.u.

wB97XD free energy: $\quad-20431.381059$ a.u.

wB97XD SCF energy in solution: $\quad-21895.67365220$ a.u.

wB97XD enthalpy in solution: $\quad-21893.998104$ a.u.

wB97XD free energy in solution: $\quad-21894.275934$ a.u.

wB97XD free energy in solution after quasi-harmonic correction: -21894.24373 a.u.

Imaginary frequency: $\quad-795.1133 \mathrm{~cm}-1$

Cartesian coordinates

\begin{tabular}{|c|c|c|c|}
\hline TO & $\mathrm{X}$ & Y & $\mathrm{Z}$ \\
\hline D & 871014 & 59325 & -0.3 \\
\hline & -1.504487 & 857 & 00 \\
\hline D & 1.6 & 1.6 & 4.0 \\
\hline & 1.033033 & 3.8 & 4.0 \\
\hline 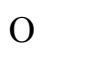 & -0.534798 & -0.765324 & 4.37283 \\
\hline D & 0.175725 & -2.918856 & 4.7309 \\
\hline C & -0.851090 & 1. & 1. \\
\hline$\gamma$ & 0.162859 & 1.003620 & 2.16641 \\
\hline & 0.690030 & 1.905642 & 3.06 \\
\hline
\end{tabular}



$\begin{array}{llll}\text { C } & 0.306377 & 3.237631 & 3.127002\end{array}$
$\begin{array}{llll}\text { C } & -0.667930 & 3.738907 & 2.299681\end{array}$
$\begin{array}{llll}\text { C } & -1.242147 & 2.839449 & 1.388182\end{array}$
$\begin{array}{llll}\text { C } & 1.637078 & 2.820147 & 4.835112\end{array}$
$\begin{array}{llll}\text { C } & 1.521032 & -1.045812 & 1.319658\end{array}$
C $\quad \begin{array}{llll}\text { C } & 1.963763 & -2.344865 & 1.568853\end{array}$
$\begin{array}{llll}\text { C } & 1.570754 & -3.075909 & 2.698910\end{array}$
C $\quad 0.703462-2.453887 \quad 3.561206$
$\begin{array}{llll}\text { C } & 0.272326 & -1.153059 & 3.339357\end{array}$
$\begin{array}{llll}\text { C } & 0.644565 & -0.406734 & 2.240373\end{array}$
$\begin{array}{llll}\text { C } & -0.802687 & -1.956474 & 5.099662\end{array}$
$\begin{array}{llll}\text { C } & -2.170520 & -1.018112 & 0.998984\end{array}$
$\begin{array}{llll}\text { C } & -2.990281 & -0.829116 & 2.113028\end{array}$
$\begin{array}{llll}\text { C } & -3.549611 & -1.913518 & 2.790181\end{array}$
$\begin{array}{llll}\text { C } & -3.242429 & -3.203789 & 2.333367\end{array}$
$\begin{array}{llll}\text { C } & -2.405757 & -3.429465 & 1.237869\end{array}$
$\begin{array}{llll}\text { C } & -1.879106 & -2.313697 & 0.582130\end{array}$
$\begin{array}{llll}\text { C } & -0.091865 & -5.611188 & 0.933934\end{array}$
$\begin{array}{llll}\text { C } & -3.157035 & -6.521787 & 1.335960\end{array}$
$\begin{array}{llll}\text { C } & -2.179508 & -5.102279 & -1.414539\end{array}$
$\begin{array}{llll}\text { C } & -6.549679 & -1.203174 & 3.551812\end{array}$
$\begin{array}{llll}\text { C } & -4.105594 & 0.011244 & 5.230596\end{array}$
C $\quad-4.821983-3.142752 \quad 5.447120$
$\begin{array}{llll}\text { C } & -3.001752 & 1.159022 & -0.671967\end{array}$
$\begin{array}{llll}\text { C } & -2.854947 & 2.283280 & -1.490475\end{array}$
$\begin{array}{llll}\text { C } & -4.258824 & 0.560425 & -0.582775\end{array}$
$\begin{array}{lllll}\text { C } & -5.362236 & 1.064402 & -1.273743\end{array}$
$\begin{array}{lllll}\text { C } & -5.179045 & 2.206474 & -2.059188\end{array}$
$\begin{array}{llll}\text { C } & -3.934582 & 2.834358 & -2.182680\end{array}$
$\begin{array}{llll}\text { C } & -2.761331 & 5.774956 & -2.248144\end{array}$
C $\quad-2.482986 \quad 3.862153 \quad-4.817403$
$\begin{array}{llll}\text { C } & -5.366251 & 5.023238 & -3.991702\end{array}$
C $\quad-6.718483-1.659689-0.433635$
$\begin{array}{llll}\text { C } & -7.895044 & 0.050450 & -2.906439\end{array}$
$\begin{array}{llll}\text { C } & -8.245369 & 1.117607 & 0.103286\end{array}$
$\begin{array}{lllll}\text { C } & 2.561377 & 1.373924 & 0.128998\end{array}$
$\begin{array}{llll}\text { C } & 2.076129 & 2.464524 & -0.593595\end{array}$ 


\begin{tabular}{|c|c|c|c|}
\hline$C$ & 2.449558 & 3.772379 & -0.282530 \\
\hline & 3.351191 & 3.954173 & 0.769401 \\
\hline & 3.870656 & 2.885801 & 1.510438 \\
\hline & 3.451371 & 1.594946 & 1.181937 \\
\hline & 6.923150 & 3.480534 & 2.245054 \\
\hline & 4.548282 & 4.831041 & 3.907371 \\
\hline & 5.128504 & 1.627401 & 4.136967 \\
\hline & 3.101617 & 6.470457 & -1.850456 \\
\hline & 0.703779 & 4.529812 & -2.805386 \\
\hline & 5.191536 & -2.943392 & -2.011684 \\
\hline & 5.590884 & -1.846741 & -1.237310 \\
\hline & 8.249079 & -3.044395 & 0.041087 \\
\hline & 4.597881 & -1.010026 & -0.723393 \\
\hline & 3.248221 & -1.250947 & -0.977374 \\
\hline & 2.891123 & -2.341691 & -1.772442 \\
\hline & 3.848806 & -3.212860 & -2.295333 \\
\hline & 8.416538 & -1.154688 & -2.543704 \\
\hline & 3.169104 & -4.170665 & -5.266156 \\
\hline & 1.468328 & -5.234042 & -2.762838 \\
\hline & 7.558912 & 0.093549 & 0.299833 \\
\hline & 0.428688 & 6.235314 & -0.101913 \\
\hline & 4.528123 & -6.194973 & -3.175631 \\
\hline & -0.983516 & 4.774134 & 2.353594 \\
\hline & -2.031038 & 3.204578 & 0.739464 \\
\hline & 2.658075 & 3.097280 & 5.098596 \\
\hline & 1.032404 & 2.607584 & 5.728538 \\
\hline T & 2.631920 & -2.823121 & 0.861417 \\
\hline & 1.926469 & -4.084208 & 2.874217 \\
\hline & -1.798715 & -2.328955 & 4.826388 \\
\hline & -0.727820 & -1.751947 & 6.169248 \\
\hline & -3.199152 & 0.186294 & 2.445848 \\
\hline & -1.223416 & -2.434249 & -0.279338 \\
\hline & 0.549476 & -4.806161 & 0.561171 \\
\hline & 0.209406 & -6.549351 & 0.456300 \\
\hline & 0.063936 & -5.700332 & 2.013247 \\
\hline & -3.008226 & -6.570316 & 2.419711 \\
\hline & -2.966753 & -7.517697 & 0.924233 \\
\hline
\end{tabular}




$$
\begin{aligned}
& \text { H } \quad-4.203814 \quad-6.266188 \quad 1.143464
\end{aligned}
$$

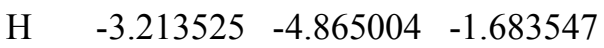

$$
\begin{aligned}
& \text { H } \quad-1.899506 \quad-6.047741 \quad-1.889839 \\
& \mathrm{H} \quad-1.535974 \quad-4.313858 \quad-1.819111 \\
& \text { H } \quad-7.258195 \quad-0.942642 \quad 4.344393 \\
& \text { H } \quad-6.936590 \quad-2.073991 \quad 3.013502 \\
& \text { H } \quad-6.496090 \quad-0.364609 \quad 2.849077 \\
& \mathrm{H} \quad-4.526811 \quad 0.071555 \quad 6.238808 \\
& \text { H } \quad-4.386439 \quad 0.922259 \quad 4.692346 \\
& \mathrm{H} \quad-3.013933 \quad-0.006443 \quad 5.303162 \\
& \mathrm{H} \quad-3.827582 \quad-3.387107 \quad 5.834330 \\
& \mathrm{H} \quad-5.199225 \quad-4.016044 \quad 4.905390 \\
& \mathrm{H} \quad-5.484855 \quad-2.963152 \quad 6.299312 \\
& \mathrm{H} \quad-1.862559 \quad 2.715817 \quad-1.607779 \\
& \mathrm{H} \quad-4.374591 \quad-0.335575 \quad 0.017161 \\
& \mathrm{H} \quad-2.451203 \quad 6.621515 \quad-2.869268 \\
& \mathrm{H} \quad-1.869034 \quad 5.369639-1.761775 \\
& \mathrm{H} \quad-3.437123 \quad 6.144513 \quad-1.470745 \\
& \mathrm{H} \quad-2.950140 \quad 3.054873 \quad-5.389711 \\
& \mathrm{H} \quad-1.516197 \quad 3.502390 \quad-4.452984 \\
& \mathrm{H} \quad-2.302083 \quad 4.706754 \quad-5.490354 \\
& \mathrm{H} \quad-5.847858 \quad 4.258341 \quad-4.609380 \\
& \text { H } \quad-5.238699 \quad 5.921037 \quad-4.604390 \\
& \mathrm{H} \quad-6.036514 \quad 5.268737 \quad-3.161804 \\
& \text { H } \quad-6.289071 \quad-1.615292 \quad 0.572664 \\
& \text { H } \quad-6.008675 \quad-2.182532-1.082410 \\
& \mathrm{H} \quad-7.640377 \quad-2.247511 \quad-0.383150 \\
& \mathrm{H} \quad-8.874899 \quad-0.435285-2.862006 \\
& \mathrm{H} \quad-7.257107 \quad-0.517687 \quad-3.590358 \\
& \mathrm{H} \quad-8.032782 \quad 1.054257 \quad-3.321264 \\
& \mathrm{H} \quad-8.387766 \quad 2.147819 \quad-0.237934 \\
& \mathrm{H} \quad-7.803462 \quad 1.147674 \quad 1.104261 \\
& \text { H } \quad-9.227556 \quad 0.639789 \quad 0.175851 \\
& \text { H } \quad 1.364867 \quad 2.266438 \quad-1.393009 \\
& \mathrm{H} \quad 3.789496 \quad 0.749581 \quad 1.778482 \\
& \mathrm{H} \quad 6.920512 \quad 4.300944 \quad 1.520318 \\
& \text { H } \quad 7.273253 \quad 2.576133 \quad 1.737742
\end{aligned}
$$




\begin{tabular}{|c|c|c|c|}
\hline 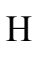 & 7.632592 & 3.726789 & 3.041747 \\
\hline & 4.908201 & 4.844712 & 4.941360 \\
\hline & 3.456869 & 4.913683 & 3.910075 \\
\hline & 4.949789 & 5.716210 & 3.403209 \\
\hline & 5.579629 & 1.857221 & 5.107484 \\
\hline & 5.713614 & 0.823424 & 3.677866 \\
\hline & 4.112137 & 1.254979 & 4.295245 \\
\hline & 2.692025 & 7.338925 & -2.375956 \\
\hline & 3.789407 & 5.950434 & -2.523948 \\
\hline & 3.674714 & 6.832917 & -0.990805 \\
\hline & -0.047813 & 3.807671 & -2.470433 \\
\hline & 1.384810 & 4.004407 & -3.482019 \\
\hline & 0.192596 & 5.318233 & -3.366463 \\
\hline & 7.754384 & -3.217452 & 1.001593 \\
\hline & 9.318866 & -2.900785 & 0.222937 \\
\hline & 8.124860 & -3.942803 & -0.572169 \\
\hline & 4.877322 & -0.151731 & -0.119559 \\
\hline & 1.832296 & -2.503838 & -1.969994 \\
\hline & 9.485485 & -0.994711 & -2.370693 \\
\hline & 8.009223 & -0.269754 & -3.041712 \\
\hline & 8.303459 & -2.007987 & -3.220141 \\
\hline & 4.148713 & -3.826228 & -5.611753 \\
\hline & 2.455182 & -3.349972 & -5.386602 \\
\hline & 2.850021 & -5.001574 & -5.903583 \\
\hline & 1.085065 & -6.088510 & -3.329539 \\
\hline & 0.765144 & -4.403588 & -2.886764 \\
\hline & 1.490084 & -5.503301 & -1.702201 \\
\hline & 7.024403 & -0.086113 & 1.238985 \\
\hline & 7.102403 & 0.958421 & -0.192828 \\
\hline & 8.596194 & 0.346008 & 0.540936 \\
\hline & -0.420073 & 5.593782 & 0.150841 \\
\hline & 0.047461 & 7.135930 & -0.593722 \\
\hline & 0.923266 & 6.527557 & 0.830110 \\
\hline & 4.203630 & -7.072242 & -3.744020 \\
\hline & 4.617289 & -6.479734 & -2.122829 \\
\hline & 5.520548 & -5.907905 & -3.538363 \\
\hline & 0.020606 & -0.187850 & -1.556228 \\
\hline
\end{tabular}




$\begin{array}{llll}\mathrm{H} & -0.430627 & -1.572584 & -2.260161 \\ \mathrm{C} & -0.545342 & -0.545106 & -3.569262 \\ \mathrm{C} & -0.021676 & 0.776716 & -3.376453 \\ \mathrm{H} & -0.724960 & 1.605660 & -3.383468 \\ \mathrm{C} & -2.057488 & -0.629271 & -3.781377 \\ \mathrm{H} & -2.221888 & -0.535913 & -4.866907 \\ \mathrm{H} & -2.524581 & 0.251999 & -3.326020 \\ \mathrm{H} & 0.973564 & 1.002355 & -3.756289 \\ \mathrm{C} & 0.281051 & -1.485570 & -4.434876 \\ \mathrm{H} & 1.337884 & -1.434790 & -4.154004 \\ \mathrm{H} & -0.046716 & -2.527342 & -4.347176 \\ \mathrm{H} & 3.650213 & 4.968105 & 1.036800 \\ \mathrm{H} & -6.027810 & 2.610862 & -2.609158 \\ \mathrm{H} & -3.674517 & -4.059561 & 2.850730 \\ \mathrm{H} & 5.956356 & -3.611965 & -2.407401 \\ \mathrm{Ge} & 7.472737 & -1.485701 & -0.858809 \\ \mathrm{Ge} & 3.253853 & -4.720887 & -3.387768 \\ \mathrm{Ge} & 5.122948 & 3.202399 & 2.969633 \\ \mathrm{Ge} & 1.669247 & 5.265309 & -1.269206 \\ \mathrm{Ge} & -3.636294 & 4.390488 & -3.325939 \\ \mathrm{Ge} & -7.076289 & 0.137241 & -1.128650 \\ \mathrm{Ge} & -4.764988 & -1.571238 & 4.276709 \\ \mathrm{Ge} & -1.962369 & -5.194835 & 0.529767 \\ \mathrm{H} & 0.192961 & -1.178730 & -5.486348 \\ \mathrm{C} & -2.786027 & -1.872532 & -3.274359 \\ \mathrm{H} & -2.685057 & -1.925463 & -2.184360 \\ \mathrm{H} & -2.314259 & -2.780950 & -3.671538 \\ \mathrm{C} & -4.268388 & -1.852960 & -3.644136 \\ \mathrm{H} & -4.789378 & -2.733468 & -3.250465 \\ \mathrm{H} & -4.751884 & -0.959257 & -3.230694 \\ & -4.411791 & -1.837483 & -4.731433\end{array}$




\section{TS-3B}

wB97XD SCF energy: $\quad-20432.77605160$ a.u.

wB97XD enthalpy: $\quad-20431.100231$ a.u.

wB97XD free energy: $\quad-20431.378413$ a.u.

wB97XD SCF energy in solution: $\quad-21895.66949400$ a.u.

wB97XD enthalpy in solution: $\quad-21893.993673$ a.u.

wB97XD free energy in solution: $\quad-21894.271855$ a.u.

wB97XD free energy in solution after quasi-harmonic correction: -21894.23919 a.u.

Imaginary frequency: $\quad-802.6602 \mathrm{~cm}-1$

Cartesian coordinates

$\begin{array}{lrrr}\text { ATOM } & \text { X } & \text { Y } & \text { Z } \\ \text { P } & -1.712940 & -0.051601 & -0.214776 \\ \text { P } & 1.719865 & -0.040893 & -0.382765 \\ \text { O } & -0.596638 & -2.040167 & 3.937381 \\ \text { O } & 0.408983 & -4.092603 & 3.788837 \\ \text { O } & 1.008445 & 0.679361 & 4.258224 \\ \text { O } & 0.038390 & 2.687834 & 4.781677 \\ \text { C } & 1.437585 & -1.279733 & 0.955334 \\ \text { C } & 0.473146 & -1.024892 & 1.967051 \\ \text { C } & 0.252714 & -2.048559 & 2.865103 \\ \text { C } & 0.870150 & -3.287723 & 2.782367 \\ \text { C } & 1.795736 & -3.557948 & 1.803640 \\ \text { C } & 2.071478 & -2.521981 & 0.900024 \\ \text { C } & -0.250280 & -3.200251 & 4.676771 \\ \text { C } & -1.288190 & 0.788795 & 1.372148 \\ \text { C } & -1.890839 & 1.998082 & 1.719626 \\ \text { C } & -1.517125 & 2.734734 & 2.852933 \\ \text { C } & -0.528983 & 2.194525 & 3.638110 \\ \text { C } & 0.061352 & 0.981202 & 3.317520 \\ \text { C } & -0.254627 & 0.255775 & 2.188454 \\ \text { C } & 0.769162 & 1.593555 & 5.316792 \\ \text { C } & 2.033479 & 1.512307 & 0.531989 \\ \text { C } & 2.828879 & 1.593457 & 1.678979 \\ \text { C } & 3.032567 & 2.808876 & 2.331082 \\ \text { C } & 2.385446 & 3.945735 & 1.825897 \\ \text { C } & 1.564158 & 3.897502 & 0.699238\end{array}$



$\begin{array}{llll}\text { C } & 1.411346 & 2.664951 & 0.059726\end{array}$
$\begin{array}{llll}\text { C } & -1.313720 & 5.179448 & 0.120686\end{array}$
$\begin{array}{llll}\text { C } & 1.181602 & 7.057886 & 0.887307\end{array}$
$\begin{array}{llll}\text { C } & 1.070727 & 5.515591 & -1.958994\end{array}$
$\begin{array}{llll}\text { C } & 5.963951 & 3.582358 & 3.278941\end{array}$
$\begin{array}{llll}\text { C } & 4.421810 & 1.140173 & 4.653361\end{array}$
$\begin{array}{llll}\text { C } & 3.424959 & 4.206117 & 5.142046\end{array}$
$\begin{array}{llll}\text { C } & 3.349380 & -0.517043 & -1.062879\end{array}$
$\begin{array}{llll}\text { C } & 3.369714 & -1.473435 & -2.083788\end{array}$
C $\quad 4.558574 \quad 0.009046 \quad-0.614525$
$\begin{array}{llll}\text { C } & 5.782020 & -0.414831 & -1.137140\end{array}$
$\begin{array}{llll}\text { C } & 5.764116 & -1.390788 & -2.136416\end{array}$
$\begin{array}{lllll}\text { C } & 4.570408 & -1.933480 & -2.628944\end{array}$
$\begin{array}{llll}\text { C } & 4.663676 & -5.069197 & -3.134626\end{array}$
$\begin{array}{llll}\text { C } & 2.866040 & -3.173565 & -4.998786\end{array}$
$\begin{array}{llll}\text { C } & 6.089404 & -3.055730 & -5.189049\end{array}$
$\begin{array}{llll}\text { C } & 7.326427 & 2.320109 & -0.704259\end{array}$
$\begin{array}{lllll}\text { C } & 8.979029 & -0.418371 & -1.214488\end{array}$
$\begin{array}{lllll}\text { C } & 7.355932 & 0.070723 & 1.546163\end{array}$
$\begin{array}{llll}\text { C } & -2.097950 & -1.755537 & 0.330173\end{array}$
C $\quad-1.475686-2.784139-0.378858$
$\begin{array}{llll}\text { C } & -1.570793 & -4.114585 & 0.028103\end{array}$
$\begin{array}{llll}\text { C } & -2.338445 & -4.391602 & 1.161652\end{array}$
$\begin{array}{llll}\text { C } & -2.986483 & -3.391442 & 1.895562\end{array}$
$\begin{array}{llll}\text { C } & -2.843162 & -2.068918 & 1.469879\end{array}$
$\begin{array}{llll}\text { C } & -5.846215 & -4.296833 & 3.041857\end{array}$
$\begin{array}{llll}\text { C } & -3.144365 & -5.420851 & 4.309826\end{array}$
$\begin{array}{llll}\text { C } & -3.975633 & -2.288897 & 4.696560\end{array}$
$\begin{array}{llll}\text { C } & -1.820060 & -6.444177 & -2.145619\end{array}$
$\begin{array}{llll}\text { C } & 0.825650 & -4.653250 & -1.975786\end{array}$
$\begin{array}{llll}\text { C } & -5.593168 & 2.085029 & -1.452369\end{array}$
$\begin{array}{llll}\text { C } & -5.719898 & 0.894790 & -0.729970\end{array}$
$\begin{array}{llll}\text { C } & -8.516651 & 1.583051 & 0.619554\end{array}$
$\begin{array}{llll}\text { C } & -4.549841 & 0.230331 & -0.353307\end{array}$
$\begin{array}{llll}\text { C } & -3.293354 & 0.729432 & -0.692323\end{array}$
$\begin{array}{llll}\text { C } & -3.209638 & 1.910953 & -1.437013\end{array}$
C $\quad-4.351064 \quad 2.616054-1.818707$ 


\begin{tabular}{|c|c|c|c|}
\hline & -8.385211 & -0.438832 & -1.866518 \\
\hline$r$ & -5.444898 & 4.209086 & -4.336295 \\
\hline & -2.412595 & 4.666413 & -3.379910 \\
\hline & -7.173275 & -1.325003 & 0.983810 \\
\hline & 0.117310 & -6.766794 & 0.386619 \\
\hline & -4.862613 & 5.717318 & -1.570579 \\
\hline & 2.302209 & -4.514242 & 1.740624 \\
\hline & 2.821235 & -2.699794 & 0.136898 \\
\hline & -1.156544 & -3.667514 & 5.061348 \\
\hline & 0.436681 & -2.921285 & 5.489331 \\
\hline & -2.685428 & 2.394082 & 1.097695 \\
\hline & -1.991897 & 3.677354 & 3.098814 \\
\hline & 1.721892 & 1.948471 & 5.711401 \\
\hline & 0.169415 & 1.099563 & 6.095153 \\
\hline & 3.275240 & 0.685083 & 2.080109 \\
\hline I & 0.777253 & 2.575489 & -0.821397 \\
\hline & -1.596249 & 4.176637 & -0.215067 \\
\hline & -1.846439 & 5.912468 & -0.493978 \\
\hline & -1.634622 & 5.293441 & 1.160310 \\
\hline & 0.929480 & 6.994767 & 1.950947 \\
\hline & 0.682736 & 7.938977 & 0.472103 \\
\hline 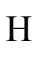 & 2.262778 & 7.204022 & 0.798412 \\
\hline & 2.130250 & 5.750413 & -2.099037 \\
\hline & 0.472561 & 6.275177 & -2.472357 \\
\hline & 0.871265 & 4.547687 & -2.431919 \\
\hline त & 6.658579 & 3.681312 & 4.119235 \\
\hline $\mathrm{H}$ & 5.862741 & 4.559945 & 2.796956 \\
\hline & 6.399194 & 2.888098 & 2.552495 \\
\hline & 4.775743 & 1.201641 & 5.687465 \\
\hline $\mathrm{H}$ & 5.157138 & 0.563035 & 4.082849 \\
\hline 4 & 3.474905 & 0.592778 & 4.633060 \\
\hline & 2.333498 & 4.122093 & 5.144366 \\
\hline & 3.679924 & 5.230828 & 4.852747 \\
\hline & 3.796030 & 4.043178 & 6.159000 \\
\hline & 2.419287 & -1.857738 & -2.450235 \\
\hline & 4.549248 & 0.773733 & 0.156237 \\
\hline & 4.610058 & -5.880930 & -3.867261 \\
\hline
\end{tabular}




\begin{tabular}{|c|c|c|c|}
\hline & 3.837269 & -5.188030 & -2.426784 \\
\hline & 5.604160 & -5.163929 & -2.582741 \\
\hline & 2.684771 & -2.139592 & -5.308463 \\
\hline & 2.026317 & -3.494407 & -4.374833 \\
\hline & 2.884465 & -3.805881 & -5.892019 \\
\hline & 6.063530 & -2.059058 & -5.639829 \\
\hline & 6.089783 & -3.798156 & -5.993318 \\
\hline & 7.029005 & -3.157926 & -4.636373 \\
\hline & 6.390915 & 2.729315 & -0.307829 \\
\hline & 7.367842 & 2.543376 & -1.774469 \\
\hline & 8.159262 & 2.830088 & -0.209498 \\
\hline & 9.896199 & 0.010759 & -0.799743 \\
\hline & 8.980959 & -0.245415 & -2.295381 \\
\hline & 8.998312 & -1.498680 & -1.039058 \\
\hline & 7.458846 & -0.994679 & 1.772951 \\
\hline & 6.396611 & 0.411884 & 1.951402 \\
\hline & 8.155422 & 0.616052 & 2.057742 \\
\hline & -0.866364 & -2.511523 & -1.237762 \\
\hline & -3.276881 & -1.263213 & 2.059649 \\
\hline & -5.867553 & -5.117361 & 2.317602 \\
\hline & -6.357158 & -3.436625 & 2.599460 \\
\hline & -6.401872 & -4.608798 & 3.932219 \\
\hline & -3.271593 & -5.429309 & 5.397302 \\
\hline & -2.074449 & -5.452647 & 4.080029 \\
\hline & -3.596899 & -6.336003 & 3.914376 \\
\hline & -4.278468 & -2.566131 & 5.711234 \\
\hline & -4.673424 & -1.526208 & 4.334801 \\
\hline & -2.977296 & -1.842932 & 4.729023 \\
\hline & -1.305185 & -7.251951 & -2.675656 \\
\hline & -2.227297 & -5.749596 & -2.886866 \\
\hline & -2.656327 & -6.876973 & -1.587394 \\
\hline & 1.536967 & -4.146936 & -1.316759 \\
\hline & 0.401865 & -3.903173 & -2.651932 \\
\hline & 1.363769 & -5.393233 & -2.577133 \\
\hline & -8.027585 & 1.913445 & 1.540848 \\
\hline & -9.521501 & 1.227560 & 0.868534 \\
\hline & -8.617346 & 2.449711 & -0.041842 \\
\hline
\end{tabular}




$$
\begin{aligned}
& \text { H } \quad-4.617439 \quad-0.696582 \quad 0.207853 \\
& \mathrm{H} \quad-2.221466 \quad 2.265176 \quad-1.726453 \\
& \text { H } \quad-9.388708 \quad-0.810105-1.635530 \\
& \text { H } \quad-7.818849 \quad-1.243808-2.344418 \\
& \text { H } \quad-8.479799 \quad 0.382659-2.583866 \\
& \text { H } \quad-6.471691 \quad 3.996083 \quad-4.021616 \\
& \text { H } \quad-5.122132 \quad 3.410992 \quad-5.011877 \\
& \mathrm{H} \quad-5.448273 \quad 5.152805 \quad-4.890904 \\
& \text { H } \quad-2.262309 \quad 5.743118 \quad-3.510190 \\
& \mathrm{H} \quad-2.216091 \quad 4.175569 \quad-4.337467 \\
& \mathrm{H} \quad-1.673403 \quad 4.309185 \quad-2.657326 \\
& \text { H } \quad-6.612735 \quad-0.992089 \quad 1.864139 \\
& \text { H } \quad-6.600813 \quad-2.120673 \quad 0.495689 \\
& \mathrm{H} \quad-8.123556 \quad-1.748898 \quad 1.323055 \\
& \mathrm{H} \quad 0.588490 \quad-6.225826 \quad 1.212395 \\
& \text { H } \quad 0.857464 \quad-7.435820 \quad-0.063340 \\
& \mathrm{H} \quad-0.686553 \quad-7.383224 \quad 0.802277 \\
& \mathrm{H} \quad-4.830075 \quad 6.699677 \quad-2.052866 \\
& \mathrm{H} \quad-4.232914 \quad 5.747512 \quad-0.676139 \\
& \mathrm{H} \quad-5.892993 \quad 5.524102-1.254635 \\
& \mathrm{Cu} \quad-0.055625 \quad 0.073490 \quad-1.754885 \\
& \mathrm{H} \quad-0.077041 \quad 1.442025 \quad-2.622255 \\
& \begin{array}{llll}
\text { C } & -0.221048 & 0.334676 & -3.857630
\end{array} \\
& \begin{array}{llll}
\text { C } & -0.269813 & -1.046717 & -3.479239
\end{array} \\
& \text { H } \quad 0.590258 \quad-1.669523 \quad-3.715090 \\
& \begin{array}{llll}
\text { C } & 1.043611 & 0.798894 & -4.564496
\end{array} \\
& \text { H } \quad 1.933741 \quad 0.436651 \quad-4.040660 \\
& \mathrm{H} \quad 1.098716 \quad 1.891541 \quad-4.616829 \\
& \mathrm{H} \quad-1.233456 \quad-1.553258 \quad-3.512352 \\
& \begin{array}{llll}
\text { C } & -1.515887 & 0.960690 & -4.364297
\end{array} \\
& \mathrm{H} \quad-2.329423 \quad 0.689035 \quad-3.681106 \\
& \mathrm{H} \quad-1.430391 \quad 2.053916 \quad-4.325483 \\
& \text { H } \quad-2.410211 \quad-5.422392 \quad 1.508229 \\
& \text { H } \quad 6.710373 \quad-1.735488-2.551558 \\
& \mathrm{H} \quad 2.522583 \quad 4.897566 \quad 2.338280 \\
& \mathrm{H} \quad-6.498117 \quad 2.619469-1.743810 \\
& \begin{array}{llll}
\mathrm{H} & 1.065053 & 0.395784 & -5.585858
\end{array}
\end{aligned}
$$




$\begin{array}{lrrr}\mathrm{C} & -1.905117 & 0.536476 & -5.783709 \\ \mathrm{H} & -1.110596 & 0.809061 & -6.490099 \\ \mathrm{H} & -2.001012 & -0.554847 & -5.826081 \\ \mathrm{C} & -3.216037 & 1.193573 & -6.216219 \\ \mathrm{H} & -3.123419 & 2.287108 & -6.216063 \\ \mathrm{H} & -3.512329 & 0.883714 & -7.224142 \\ \mathrm{H} & -4.029294 & 0.930947 & -5.528414 \\ \mathrm{Ge} & -7.468149 & 0.171474 & -0.246315 \\ \mathrm{Ge} & -4.245964 & 4.309611 & -2.789185 \\ \mathrm{Ge} & -3.995650 & -3.842255 & 3.500757 \\ \mathrm{Ge} & -0.597929 & -5.505124 & -0.933869 \\ \mathrm{Ge} & 4.547713 & -3.317336 & -4.008002 \\ \mathrm{Ge} & 7.397508 & 0.387574 & -0.390023 \\ \mathrm{Ge} & 4.213139 & 2.928522 & 3.875161 \\ \mathrm{Ge} & 0.623198 & 5.432889 & -0.053096\end{array}$


VIII. SFC Traces

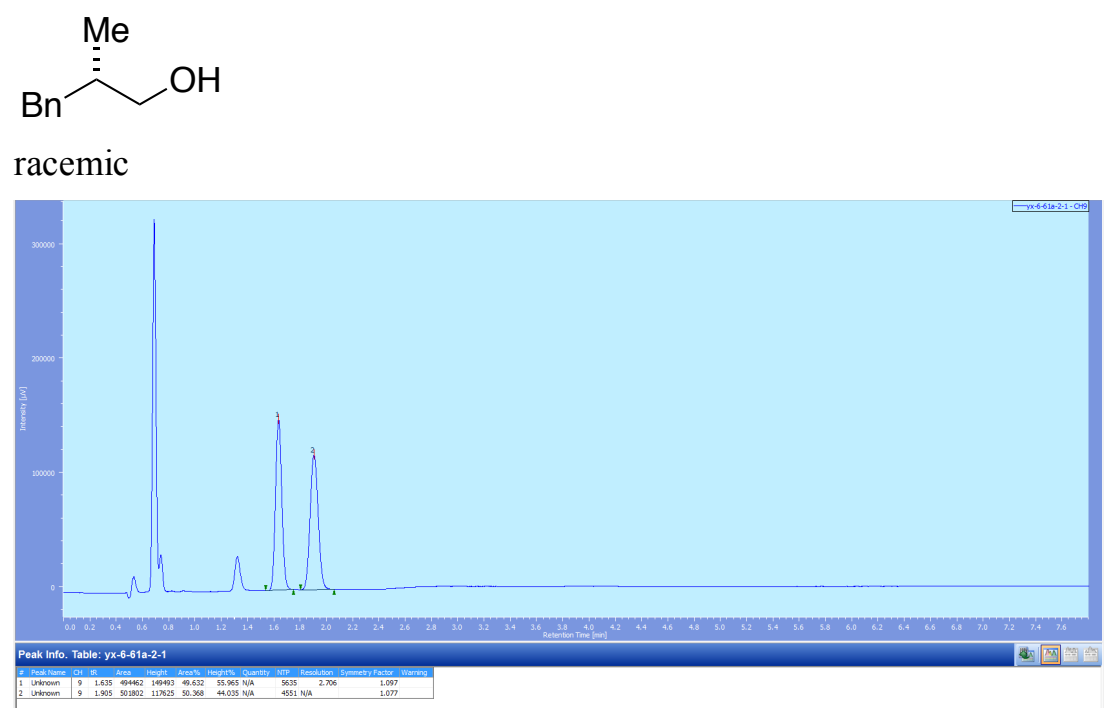

enantioenriched

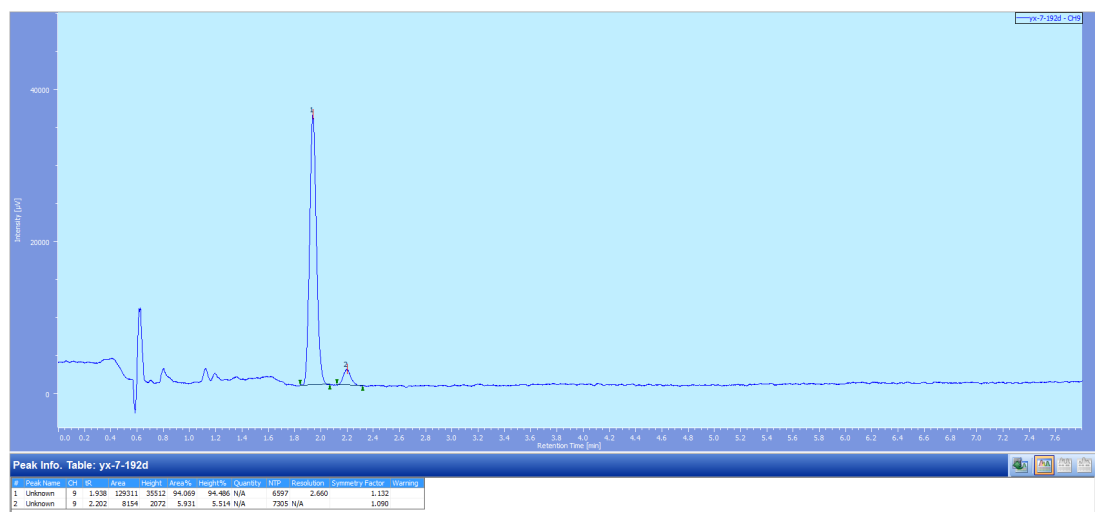




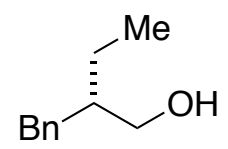

racemic

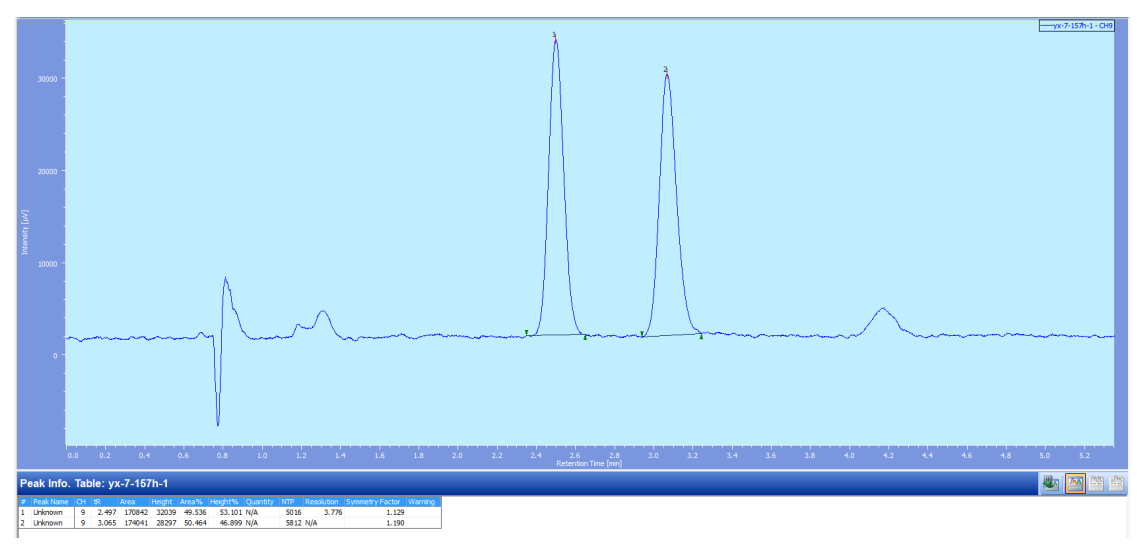

enantioenriched

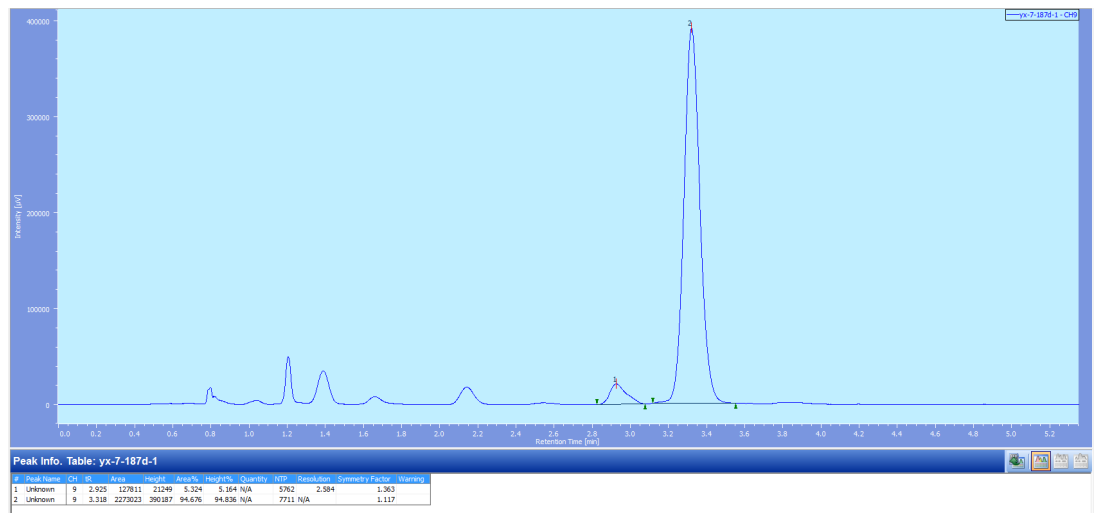




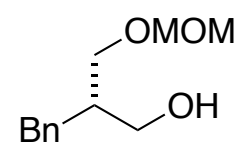

racemic

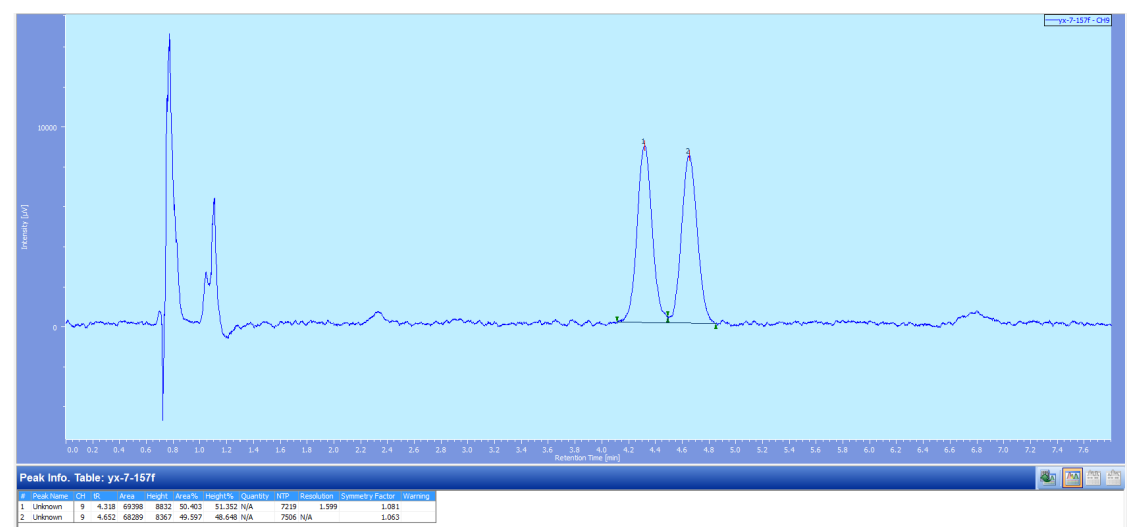

enantioenriched

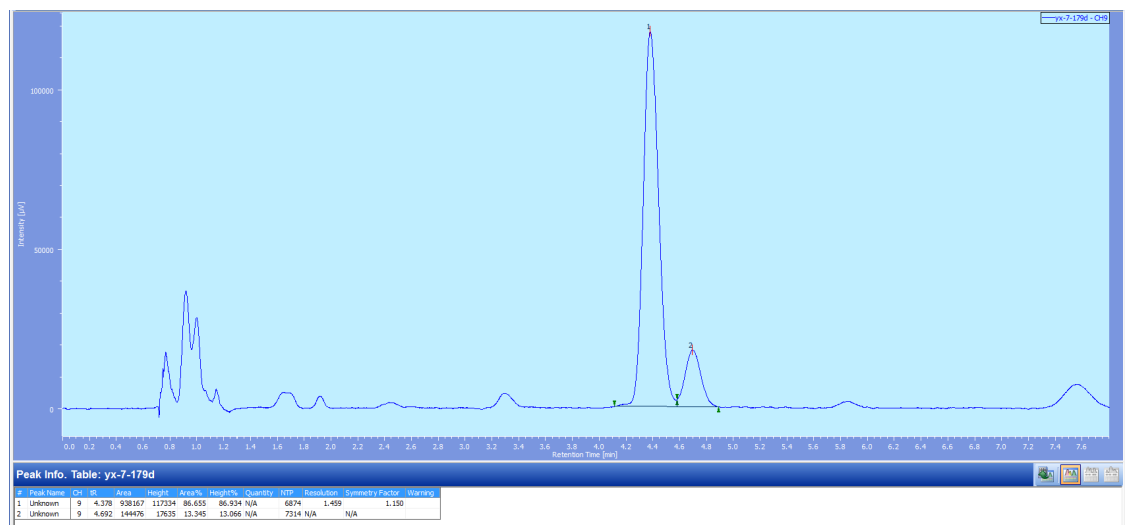




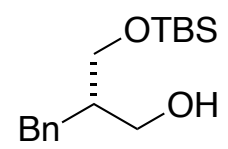

racemic

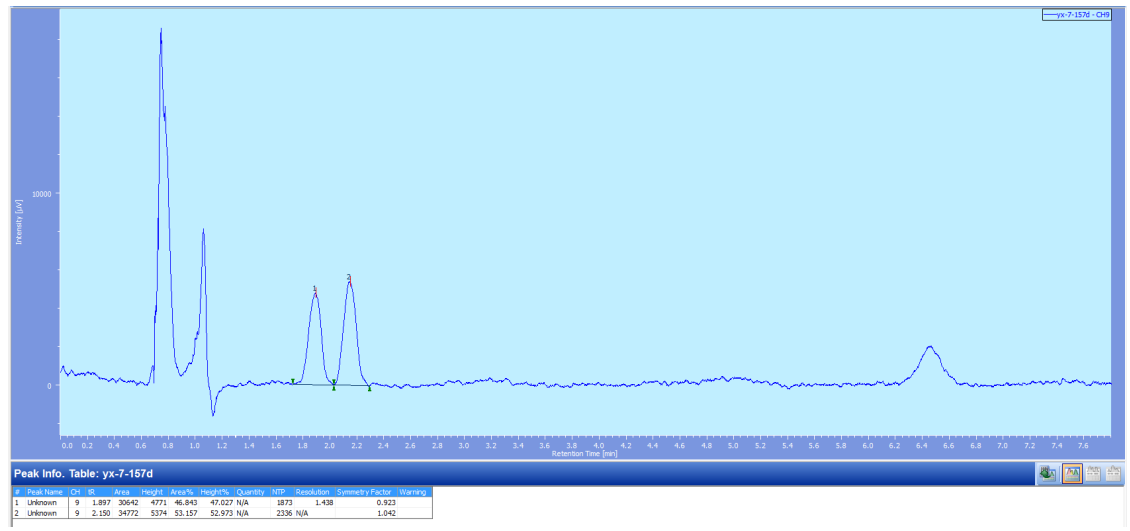

enantioenriched

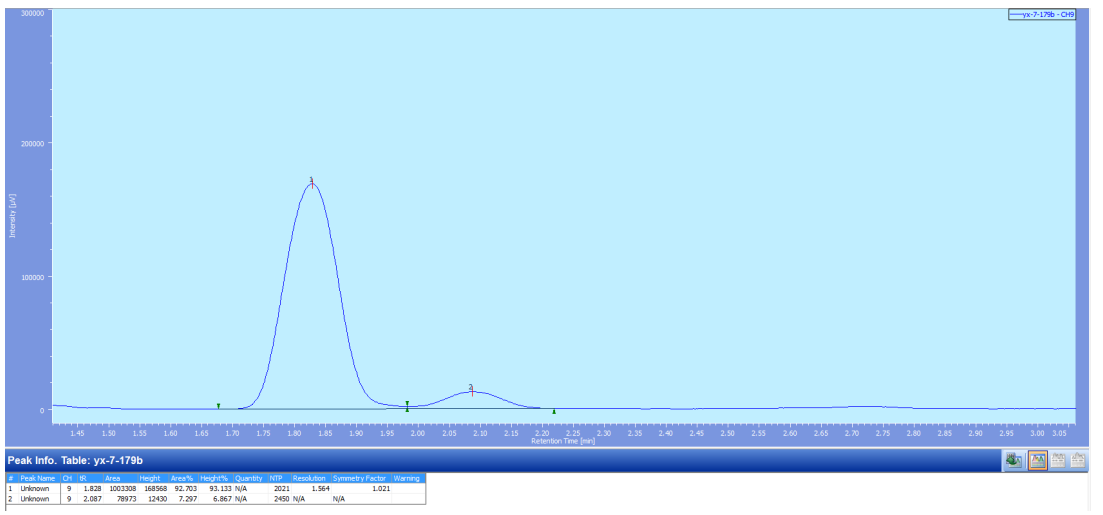




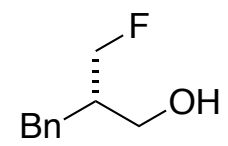

racemic

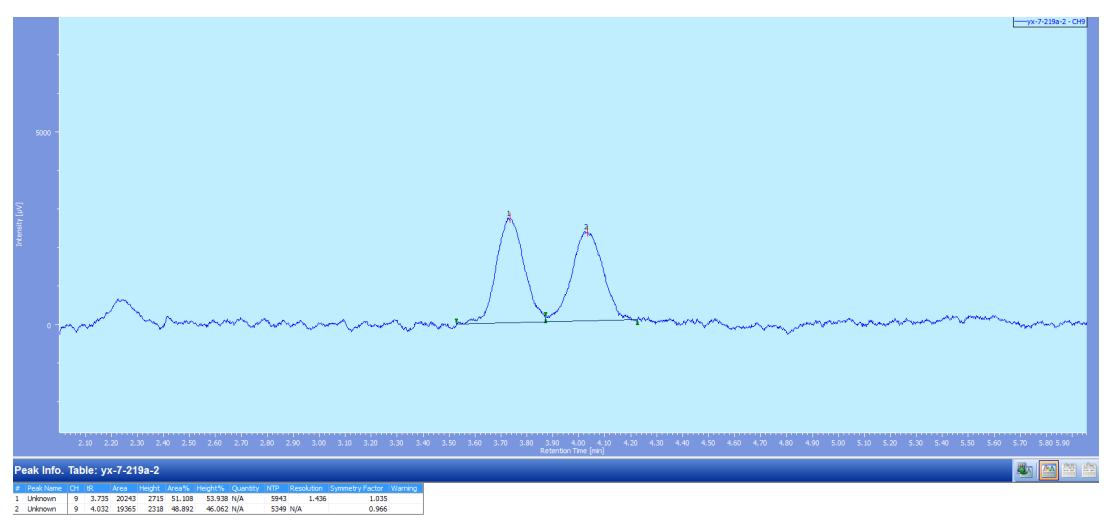

enantioenriched

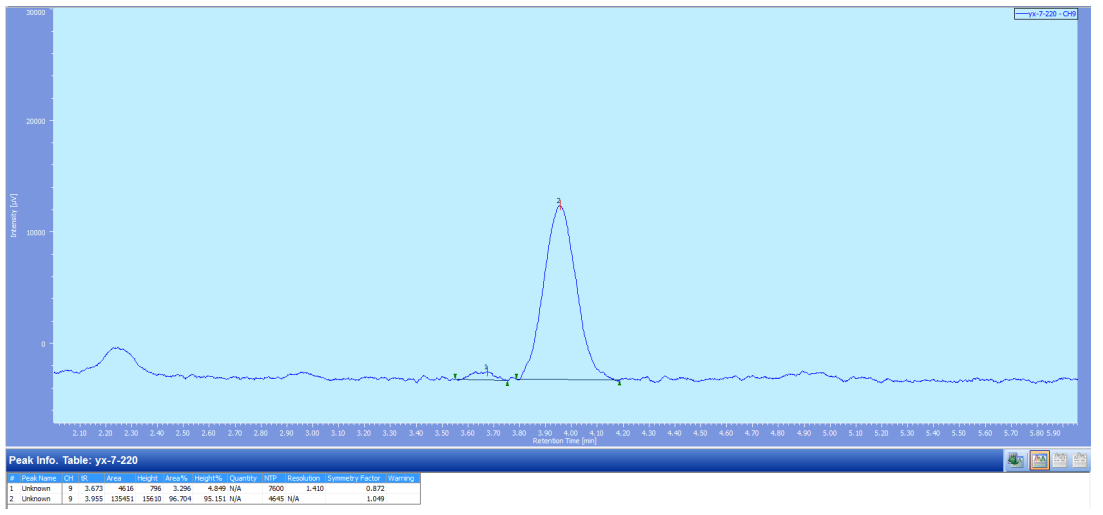




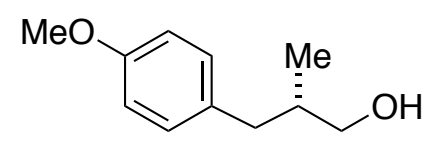

racemic

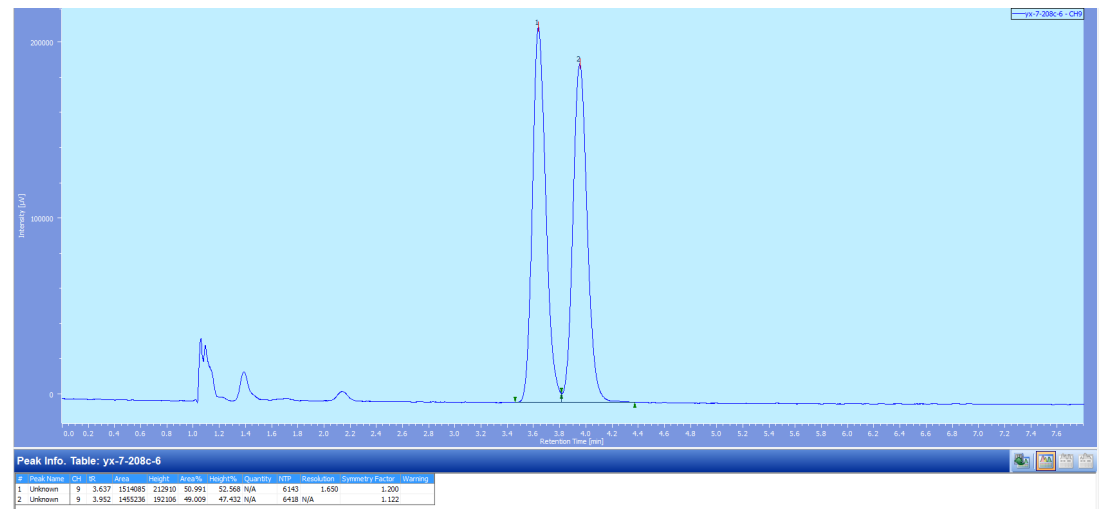

enantioenriched

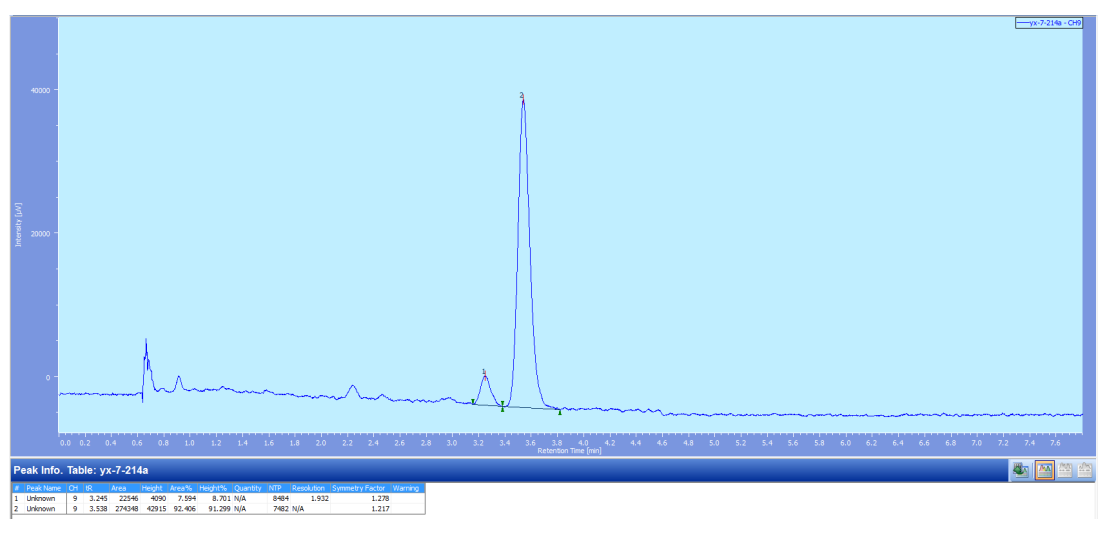




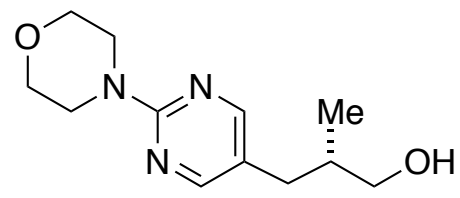

racemic

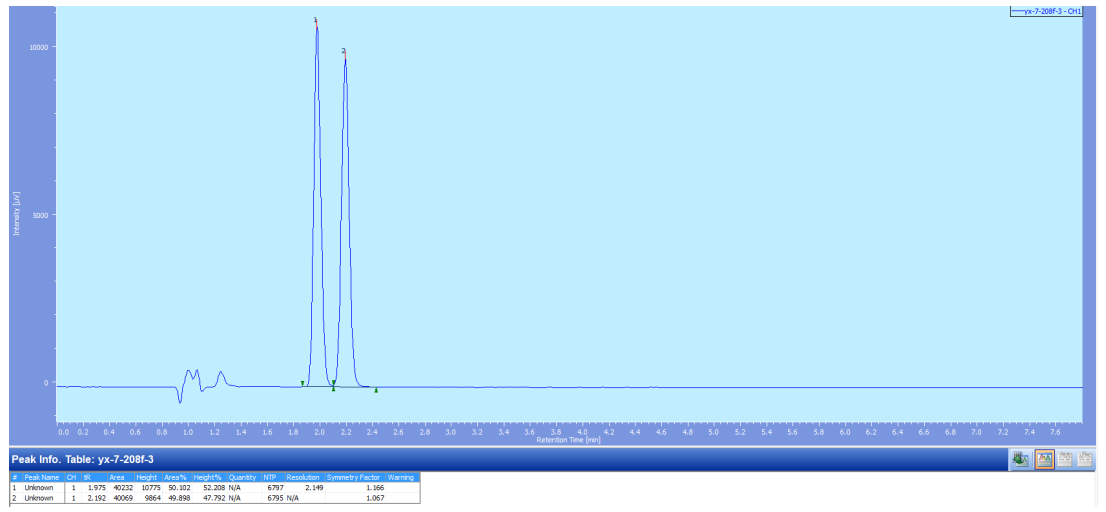

\section{enantioenriched}

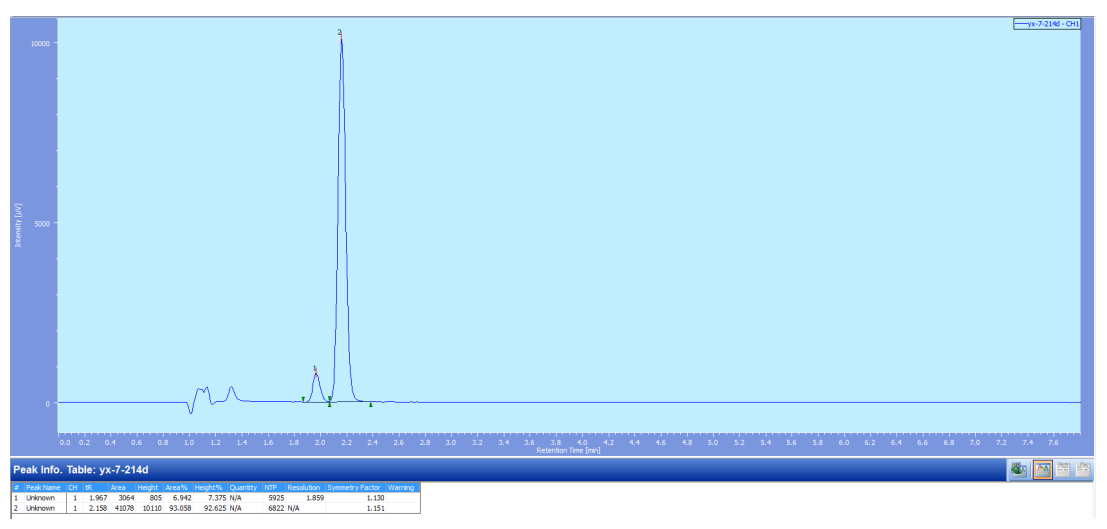




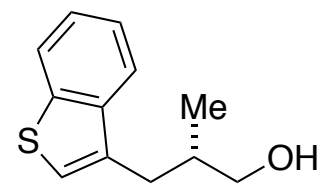

racemic

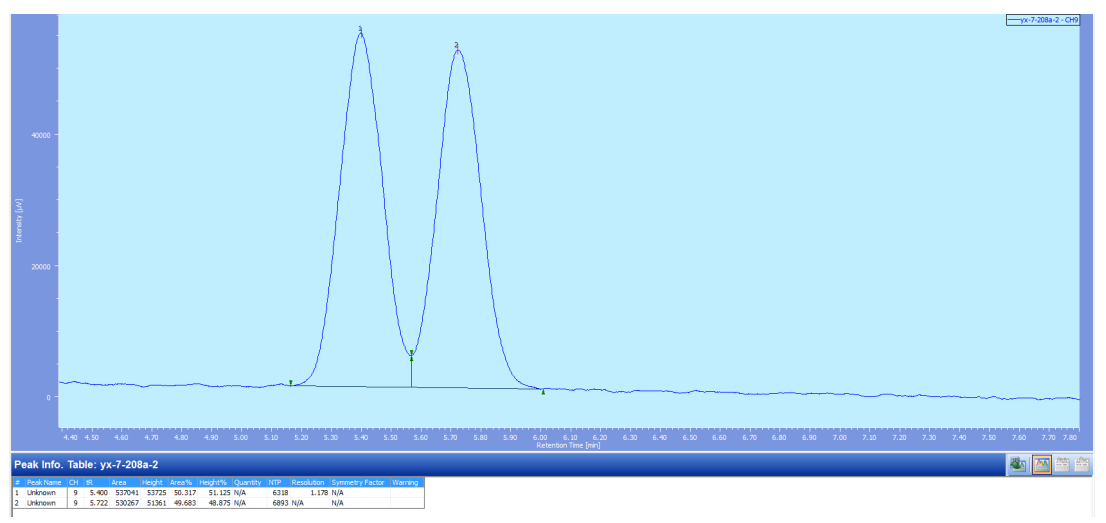

enantioenriched

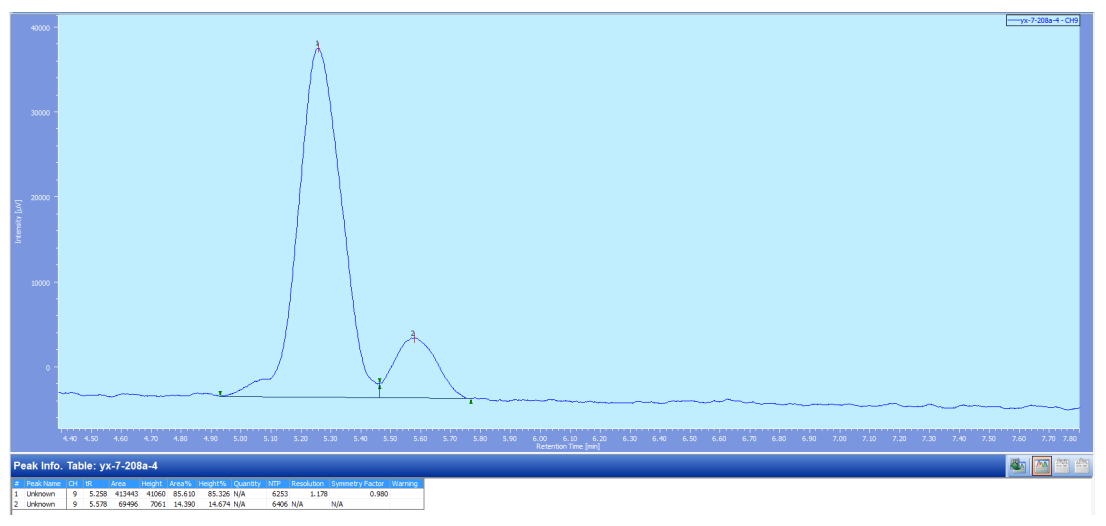




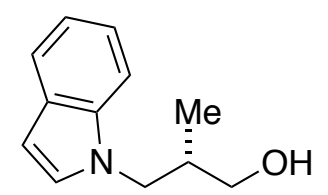

racemic (Note: The racemic sample was run with $20 \% \mathrm{IPA} / \mathrm{CO}_{2}$ instead of $15 \% \mathrm{IPA} / \mathrm{CO}_{2}$ for the enantioenriched sample.)

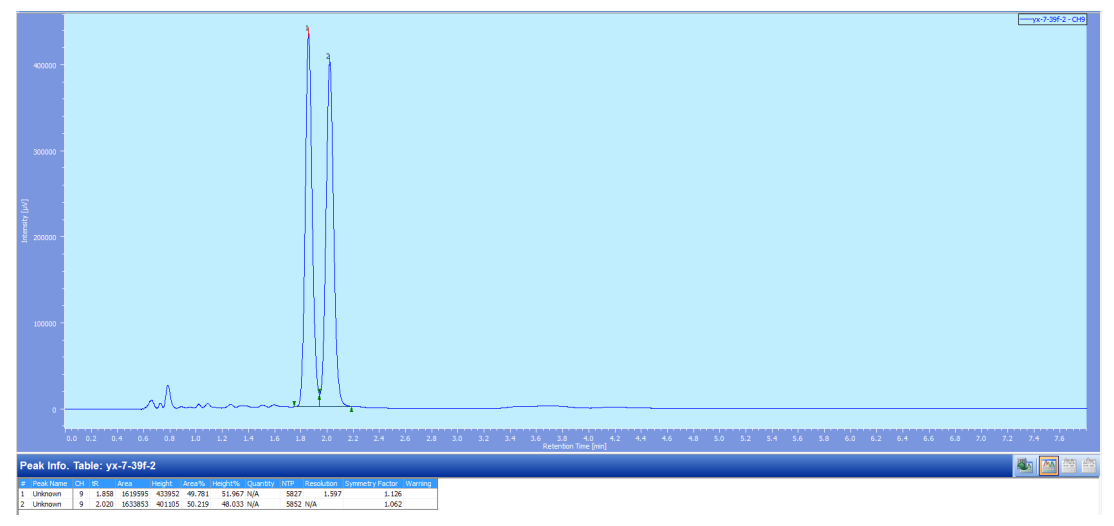

enantioenriched

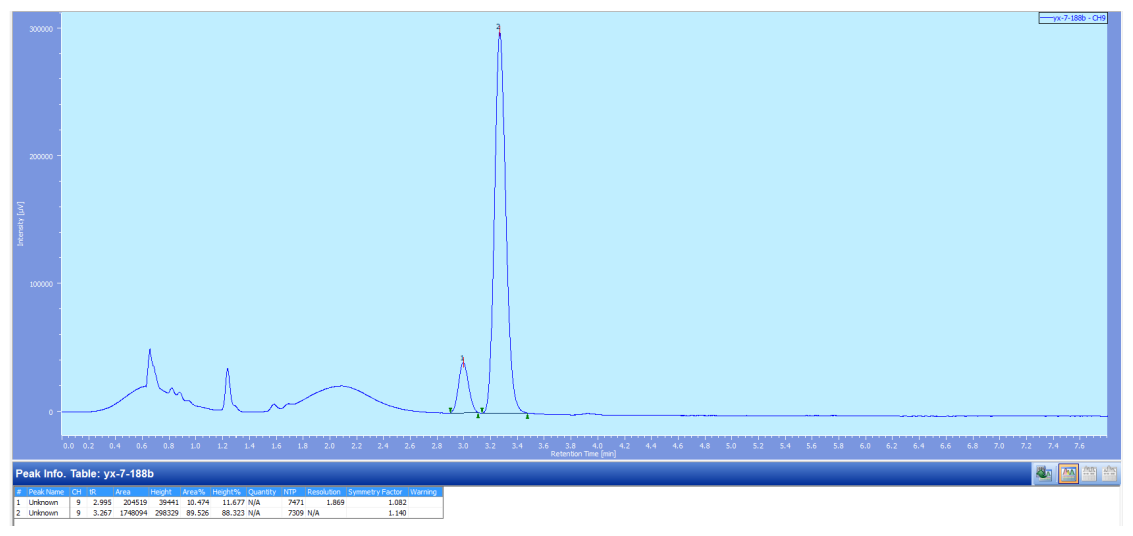




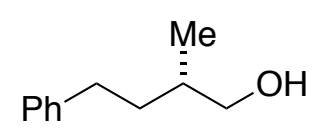

racemic

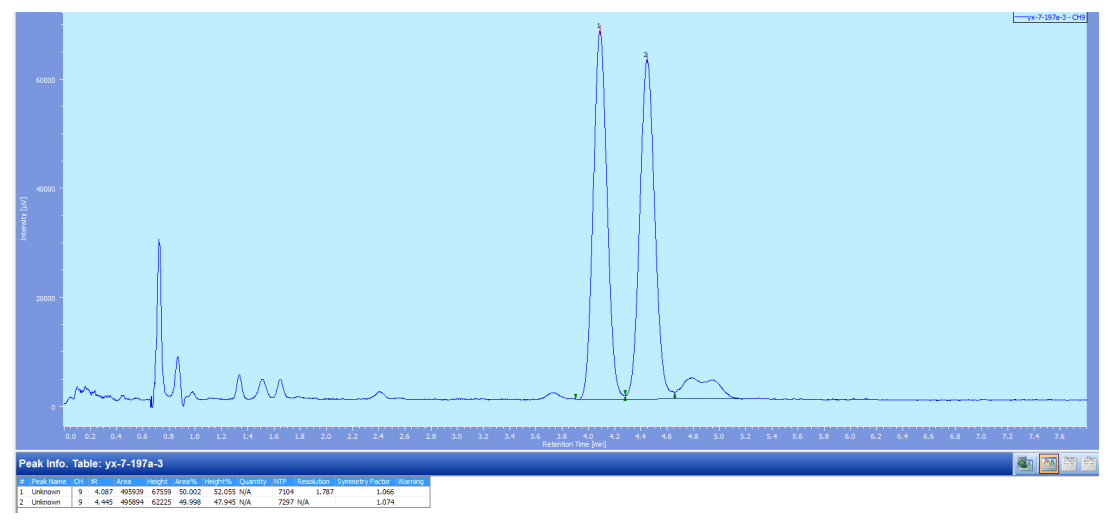

enantioenriched

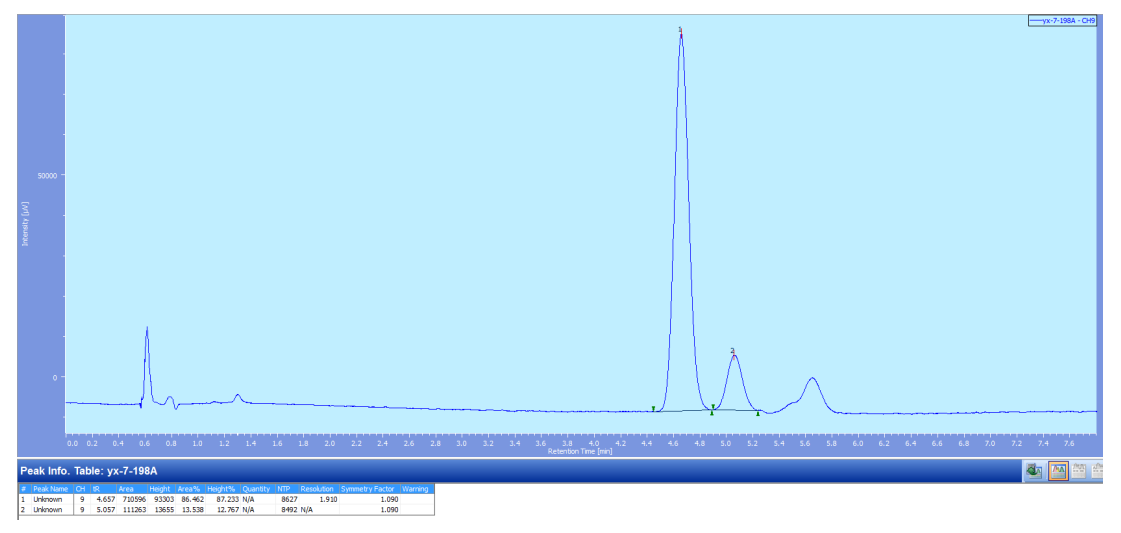




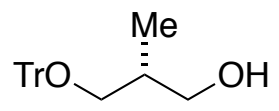

racemic (Note: The racemic sample was run with $20 \% \mathrm{IPA} / \mathrm{CO}_{2}$ instead of $15 \% \mathrm{IPA} / \mathrm{CO}_{2}$ for the enantioenriched sample.)

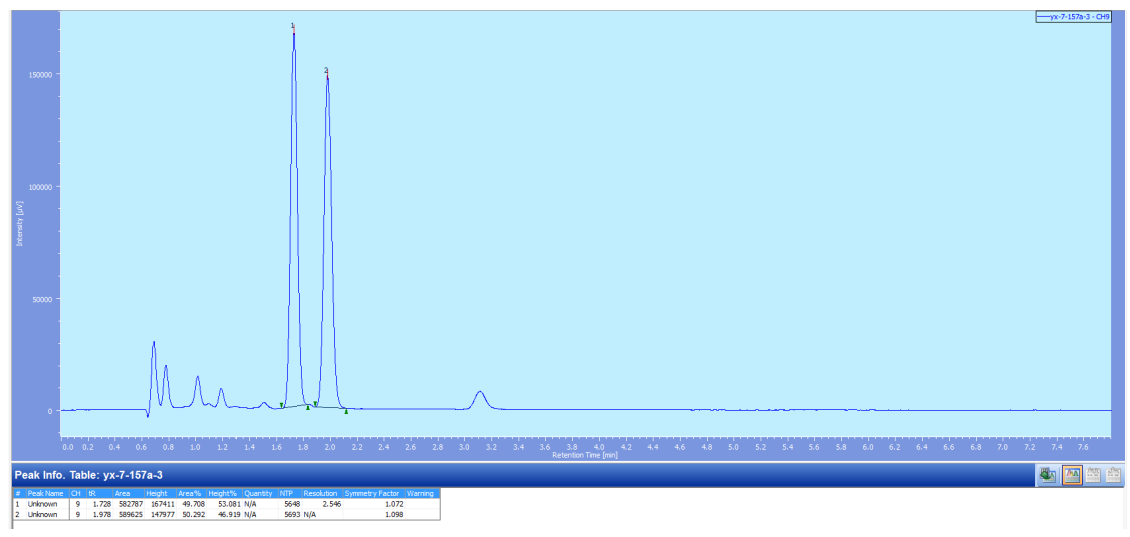

enantioenriched

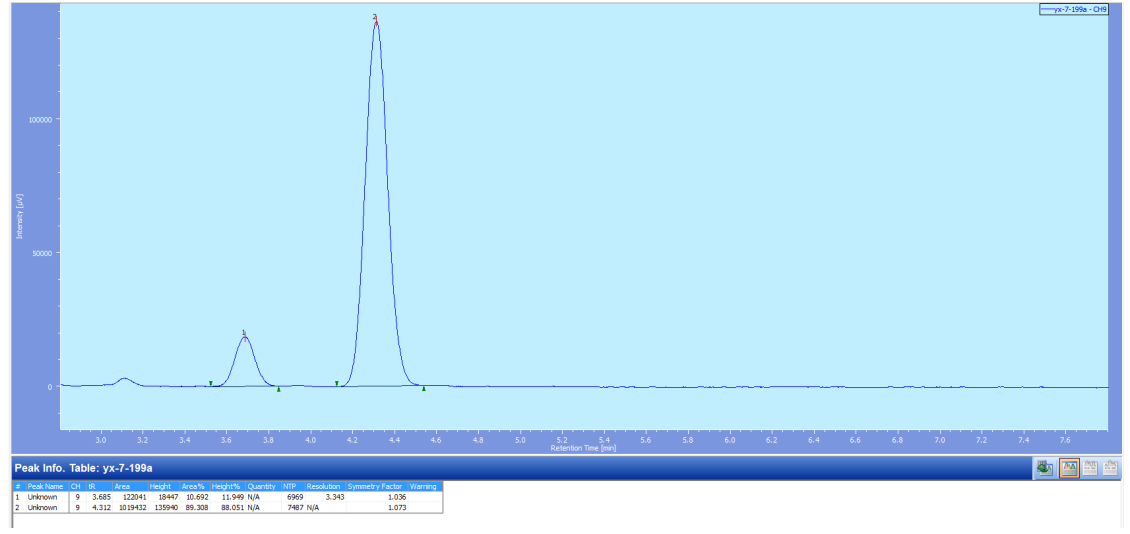




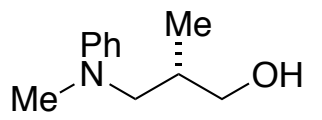

\section{racemic}

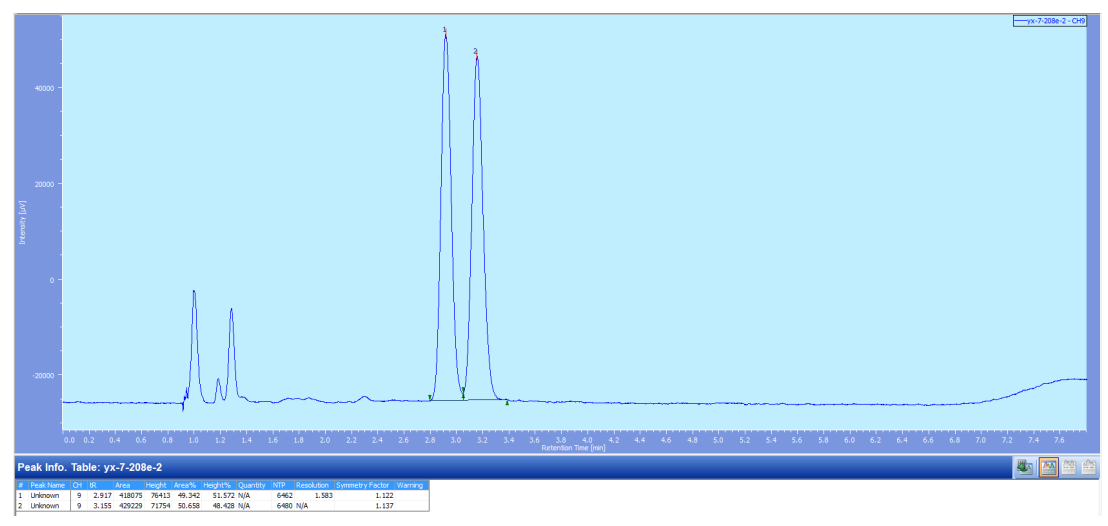

enantioenriched

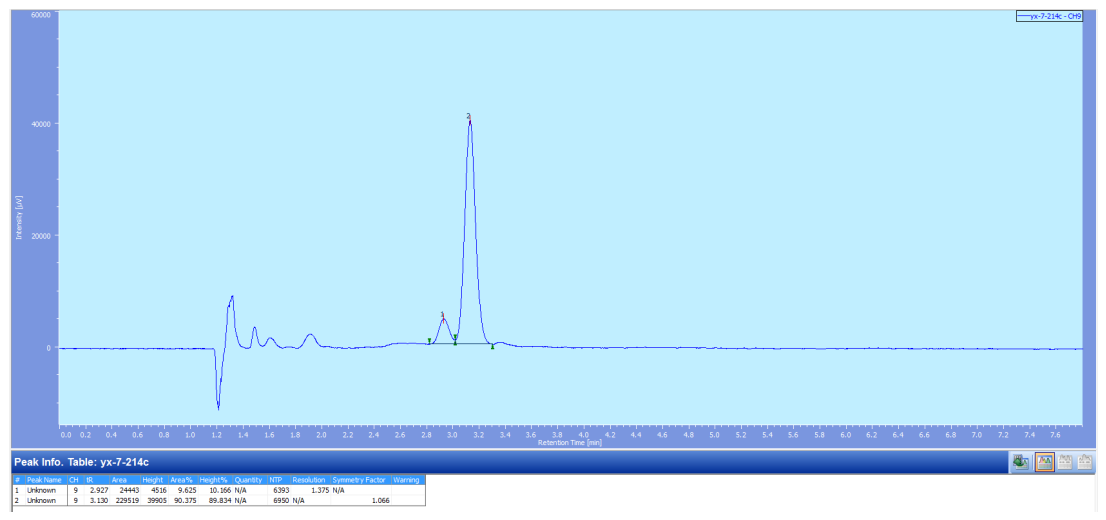




\section{NMR Spectra}<smiles>CC(CBr)CBr</smiles>
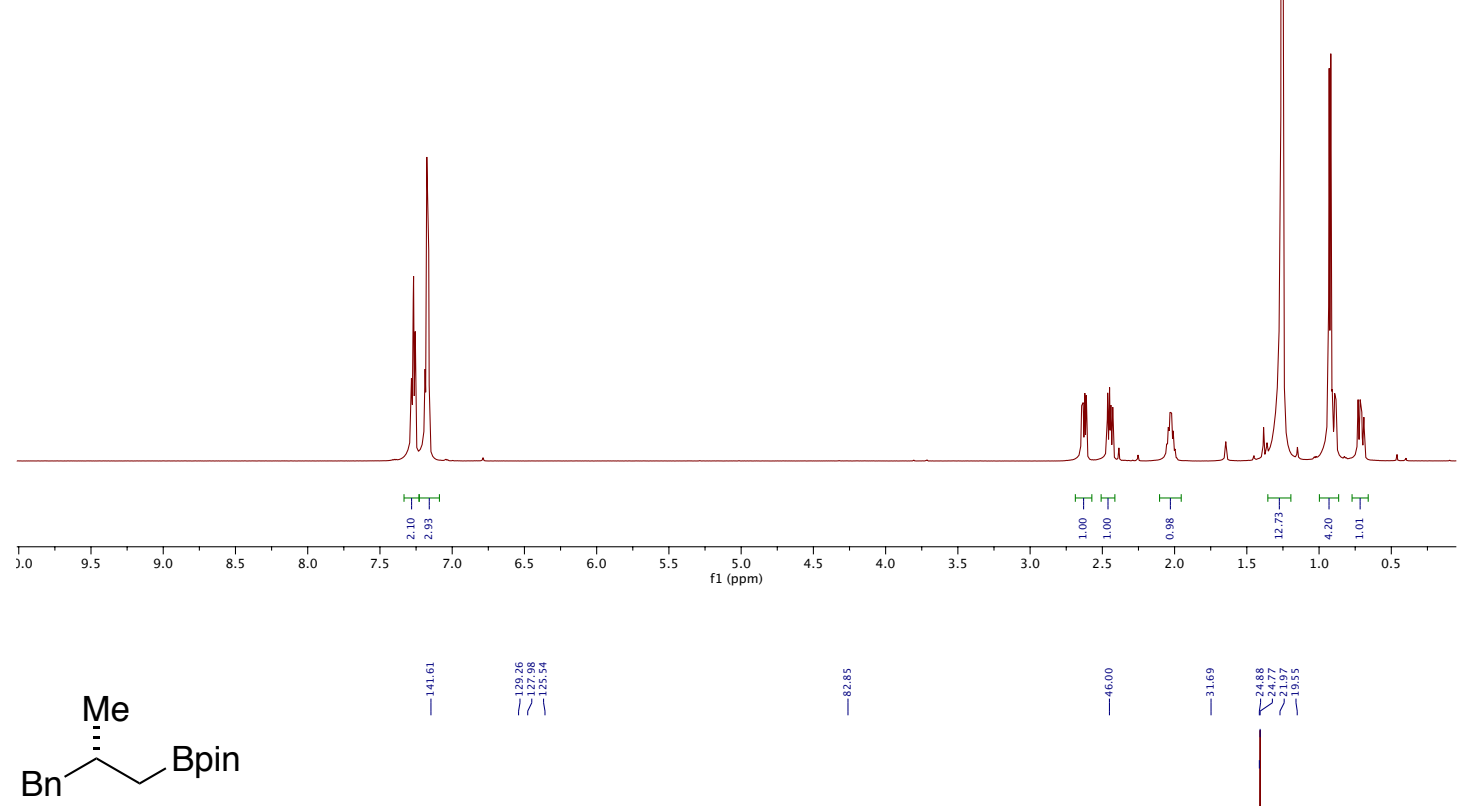

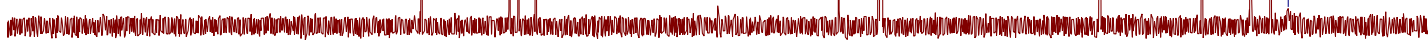

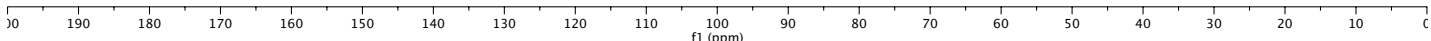


Bpin

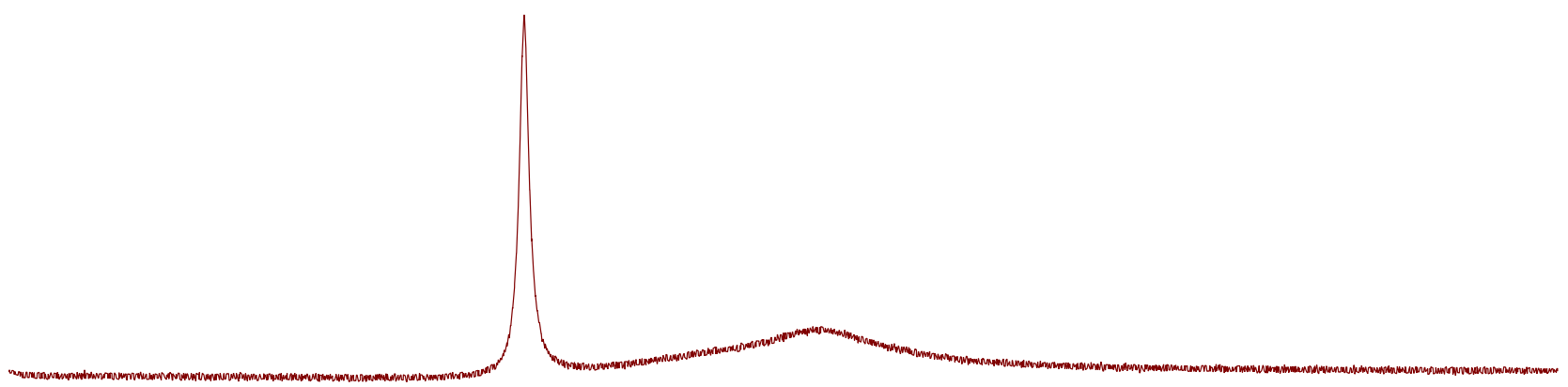


<smiles>CCC(Cc1ccccc1)Cc1ccccc1</smiles>

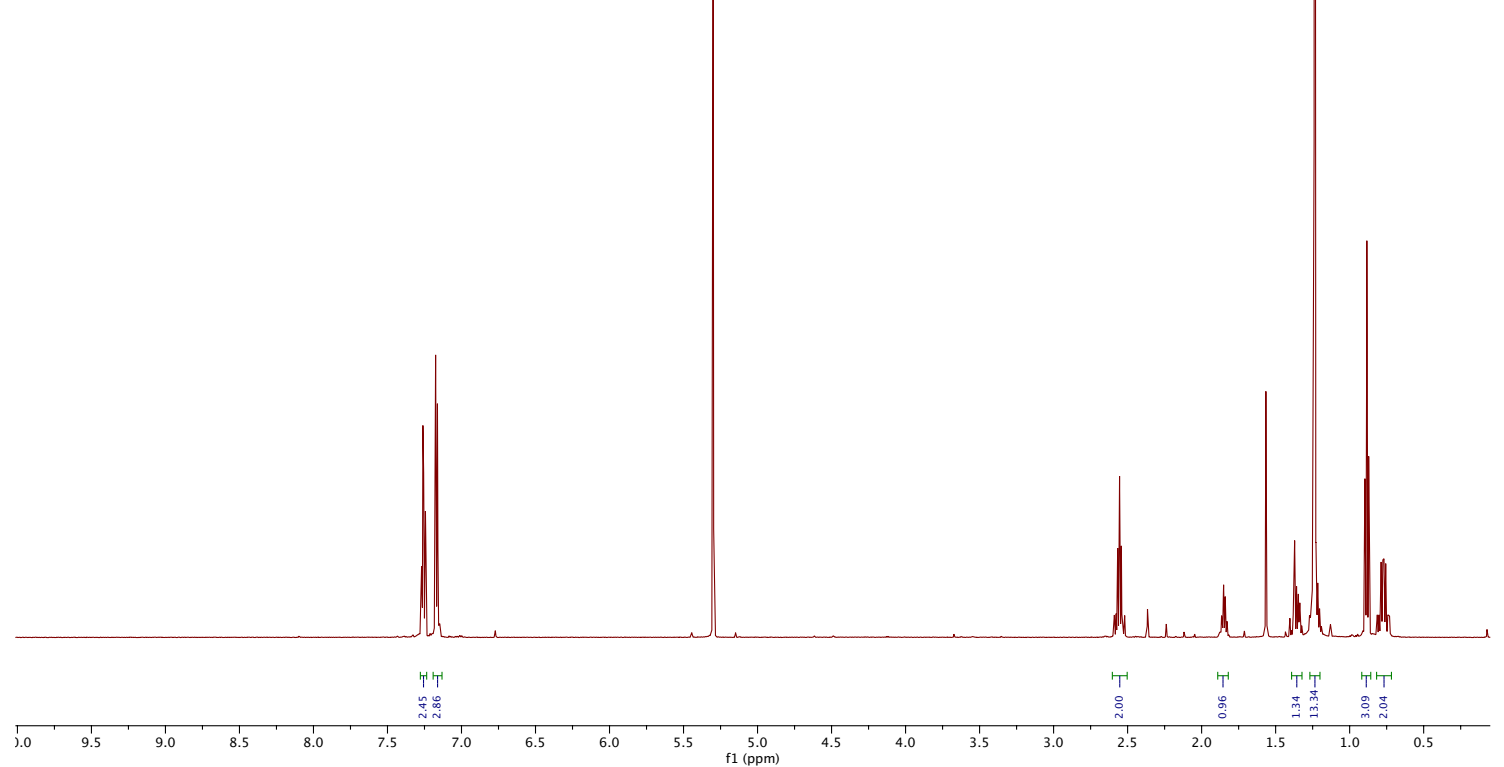<smiles>CCC(Cc1ccccc1)Cc1ccccc1</smiles> 

Bpin

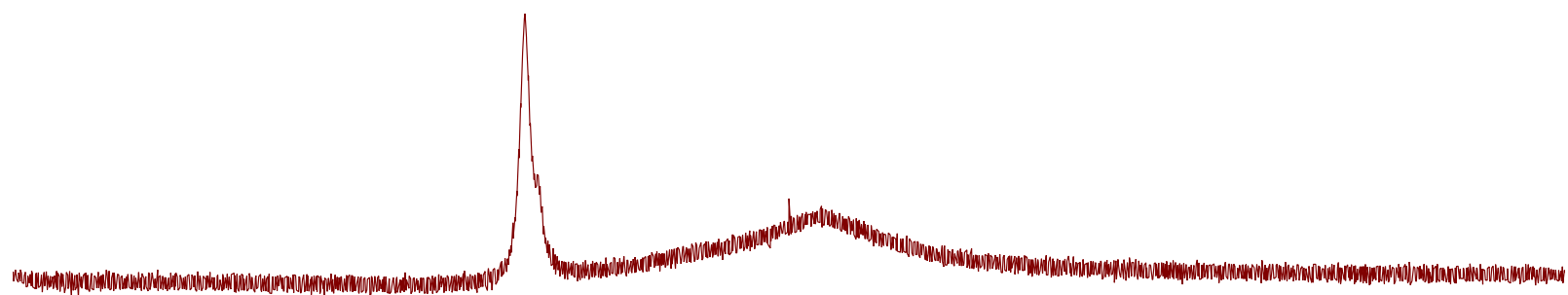


Bpin
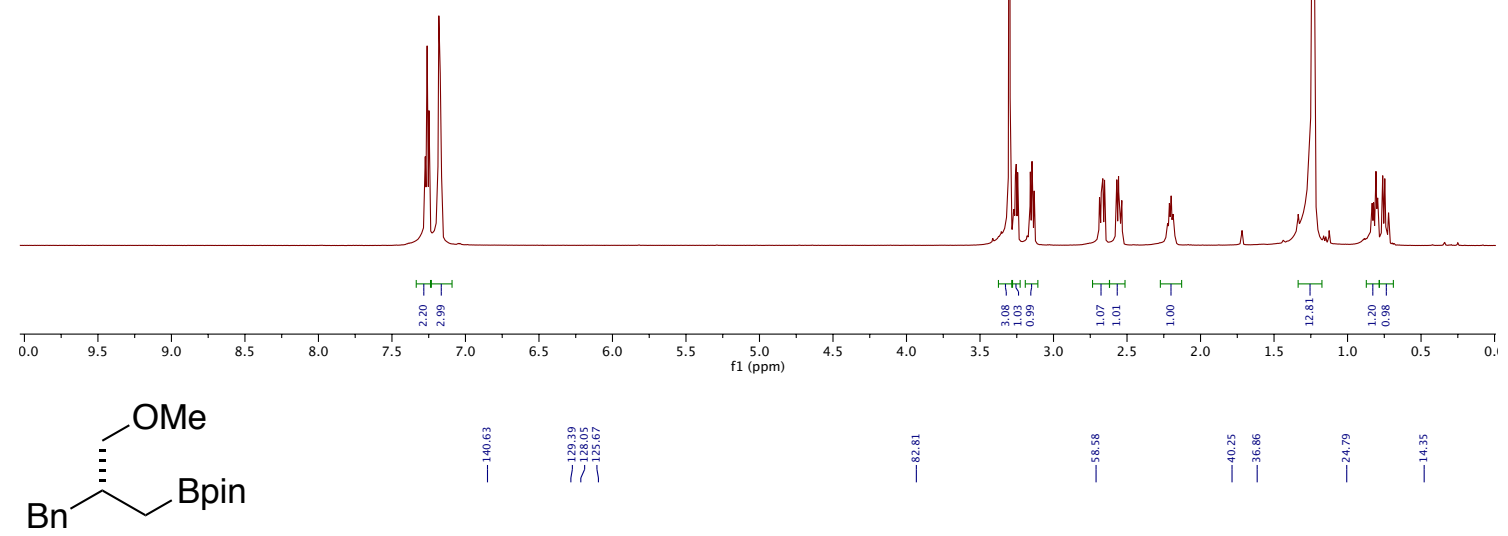

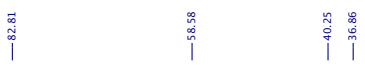
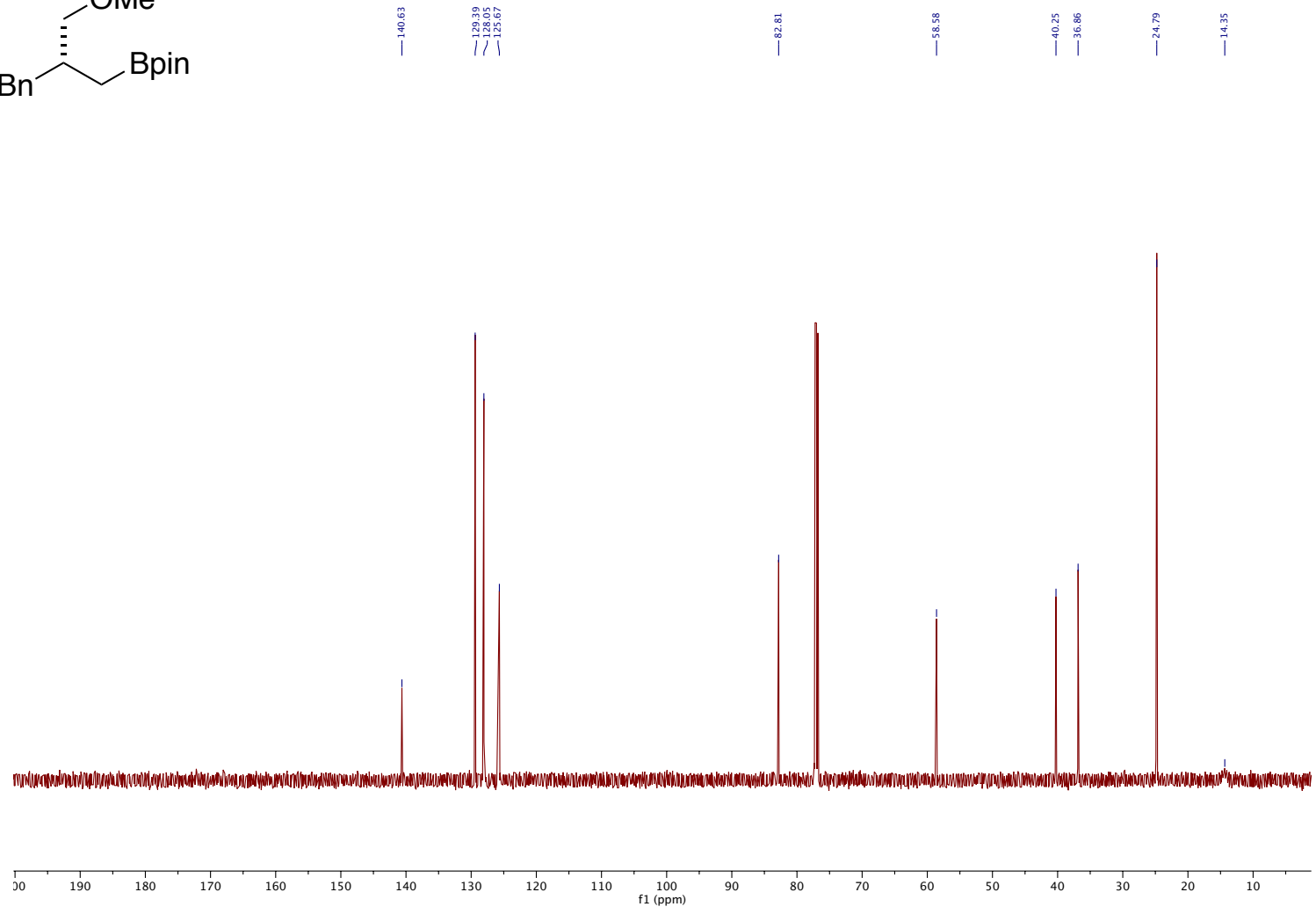

S89 


$$
\text { Bpin }
$$

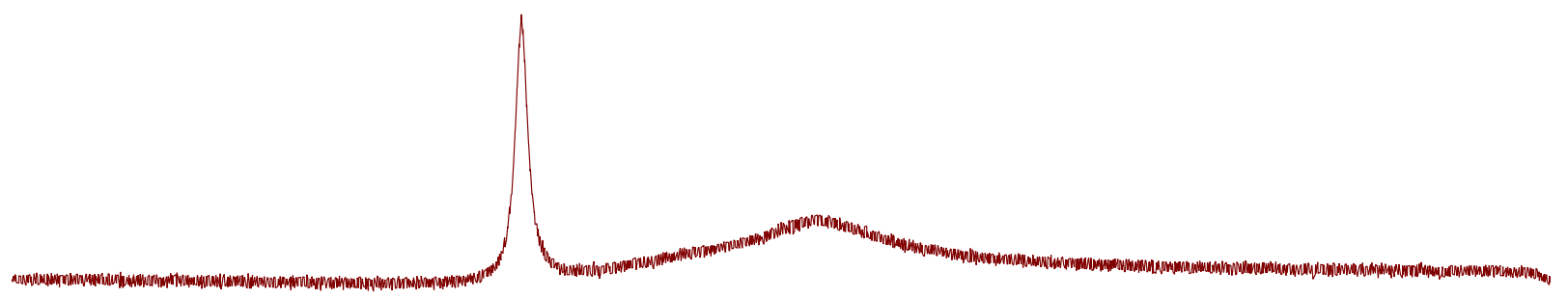



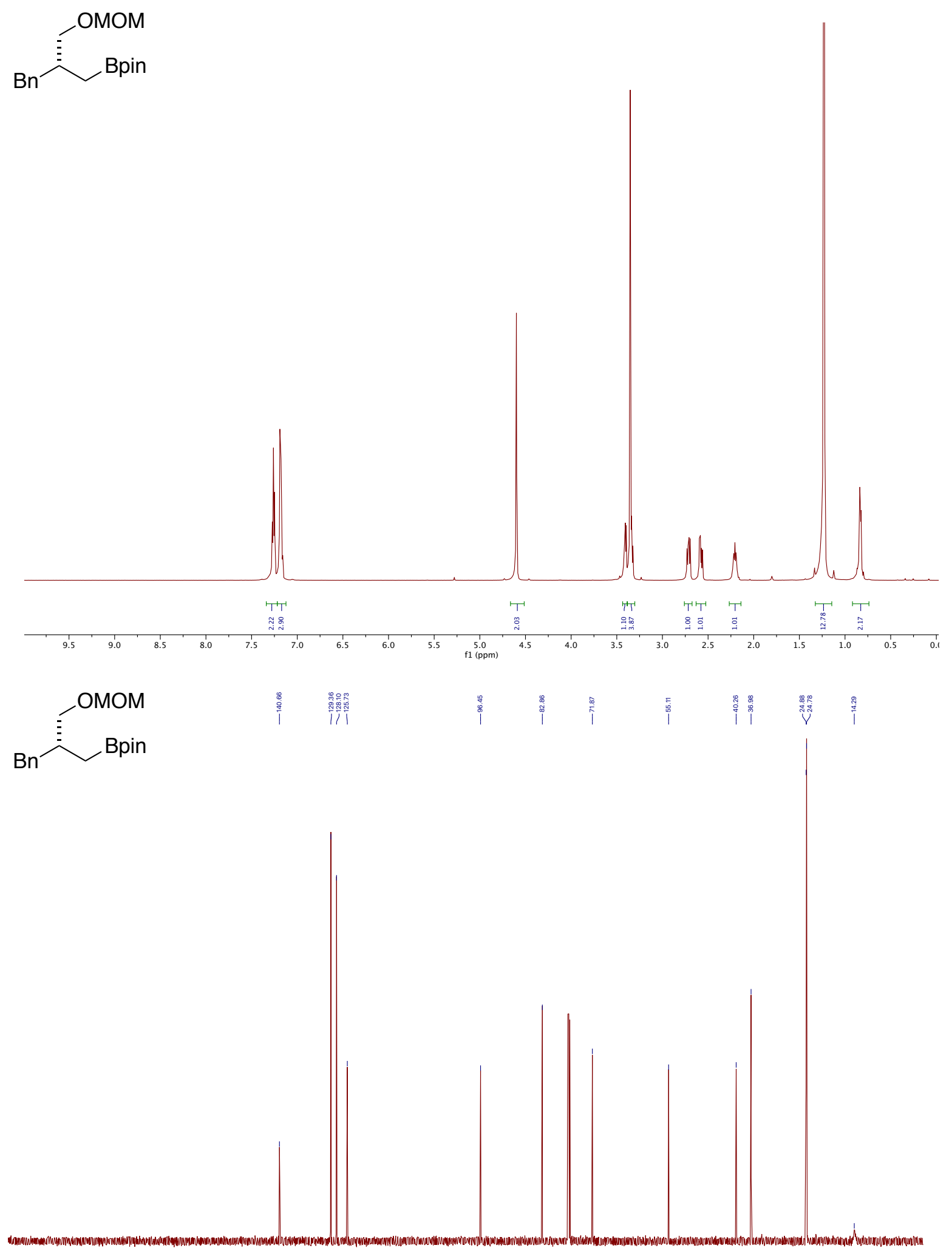

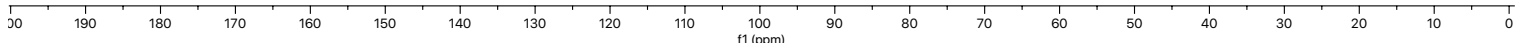



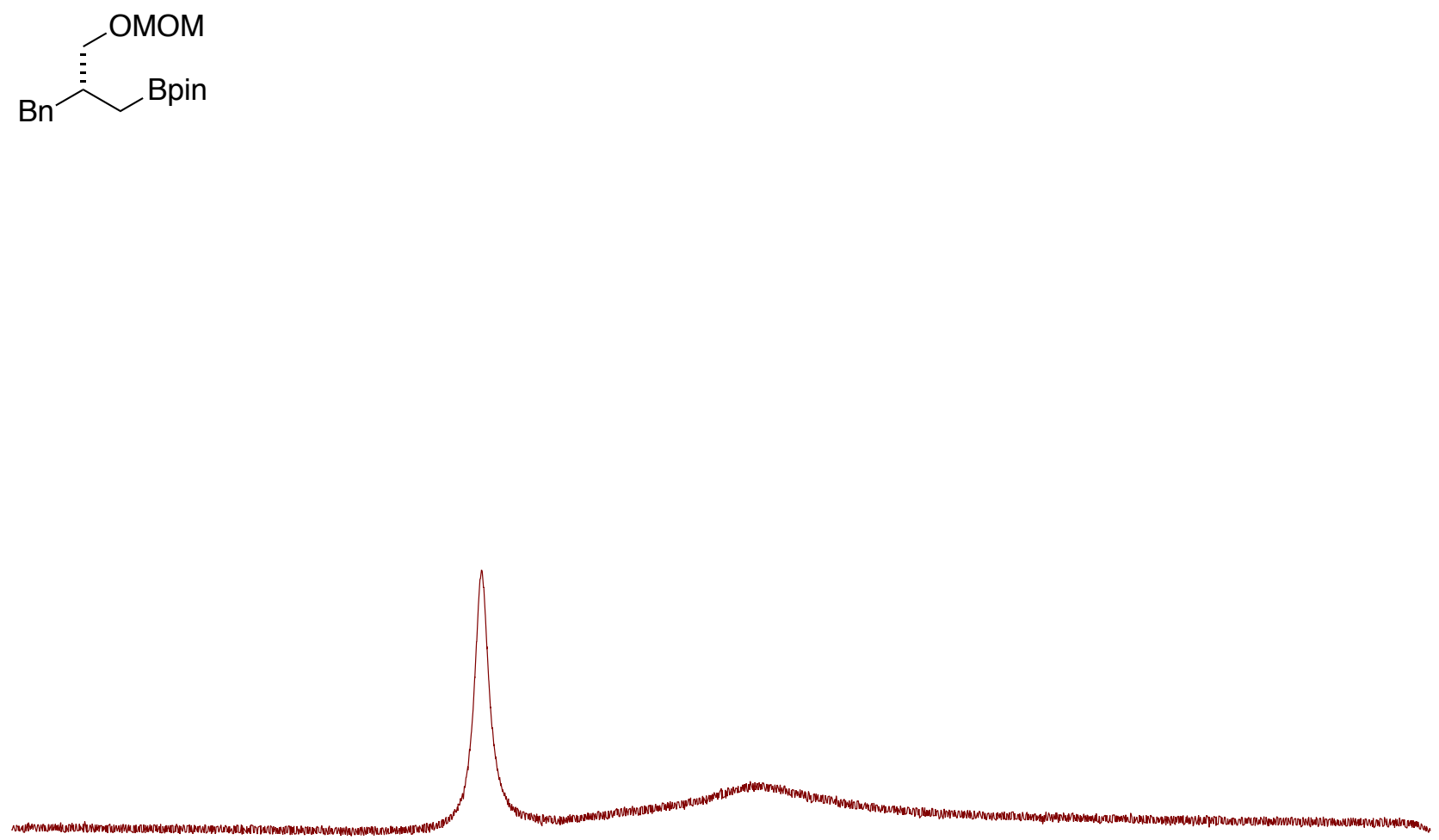

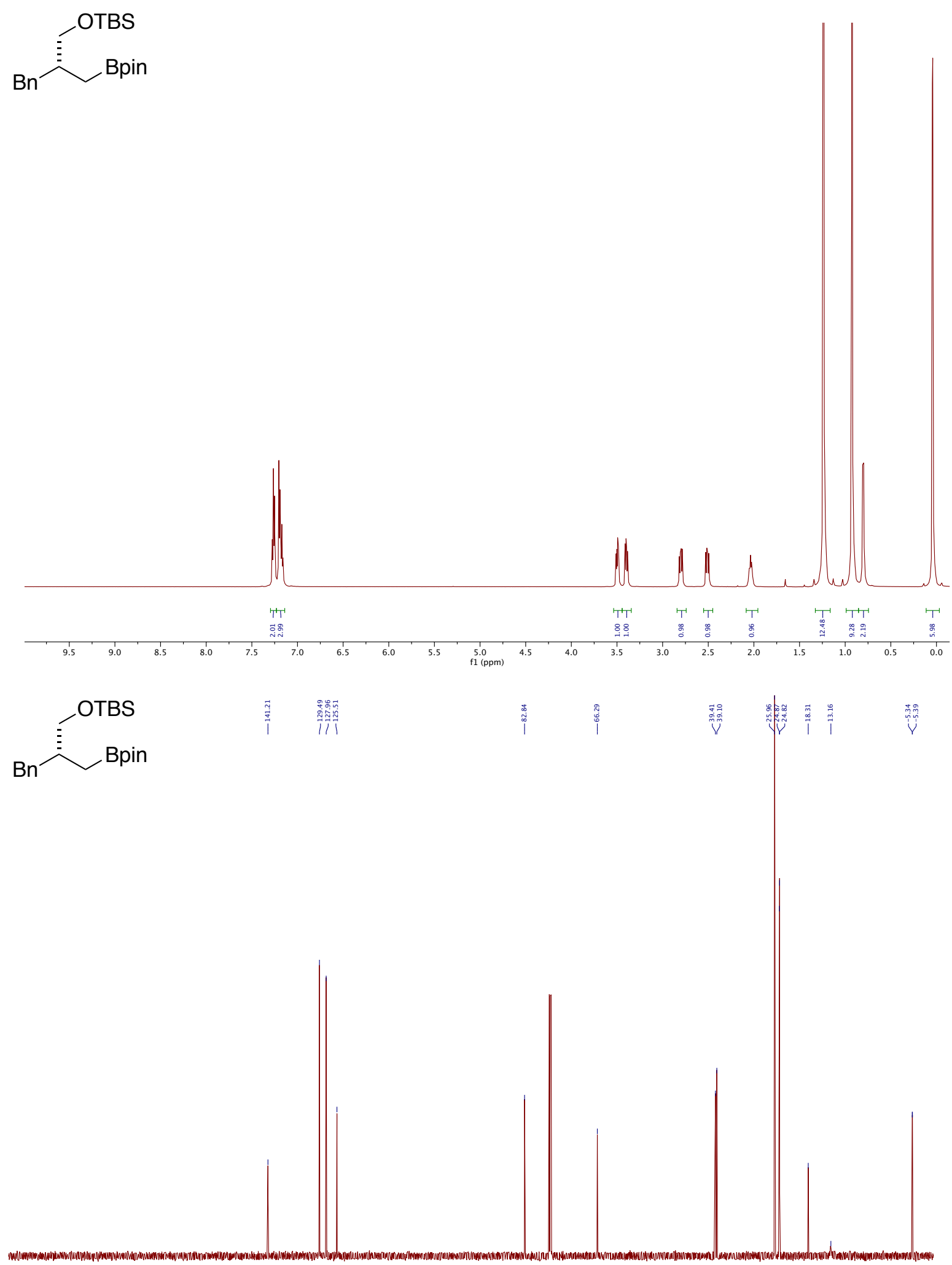

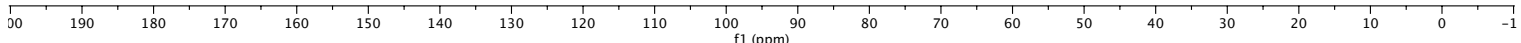



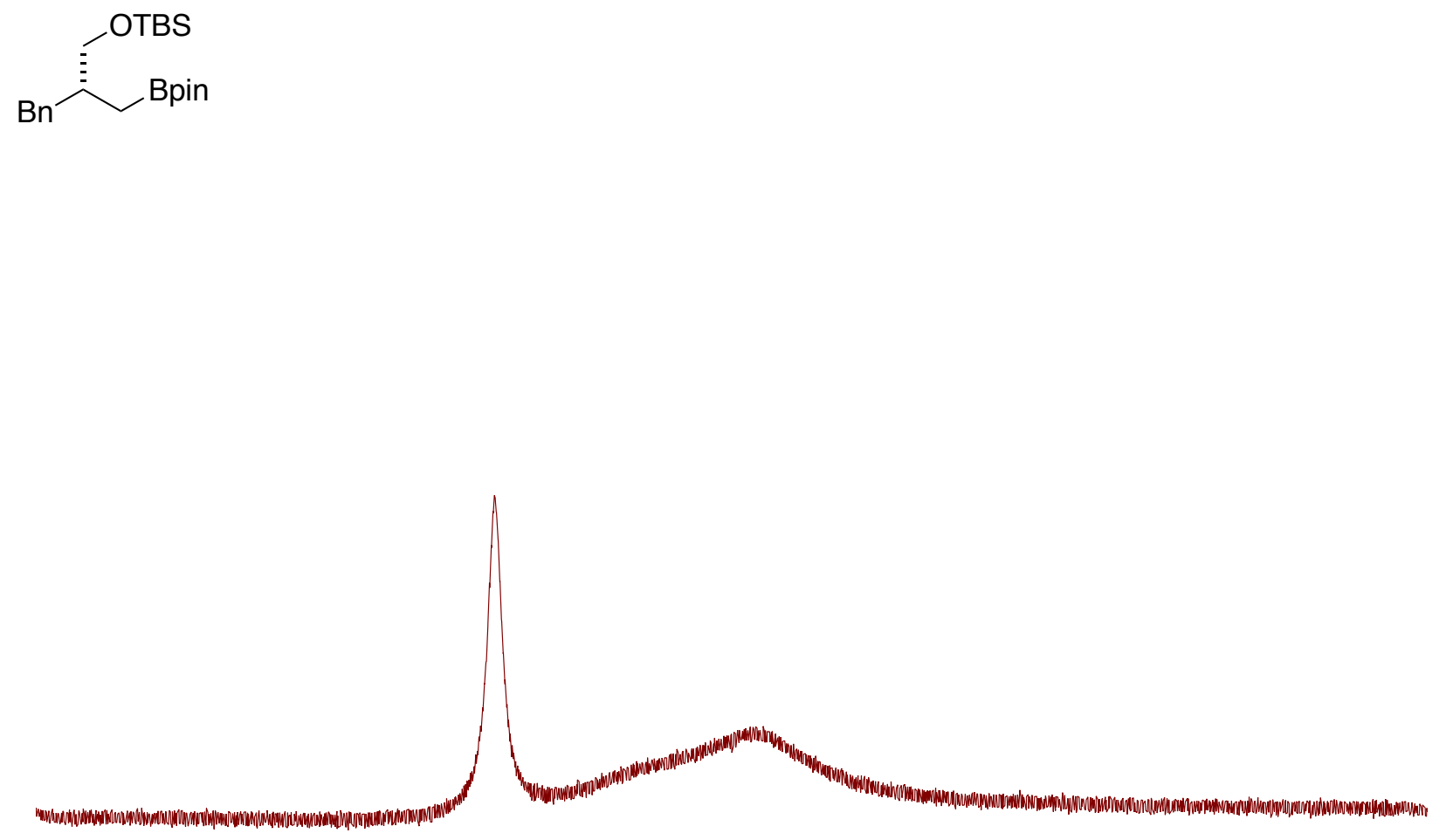

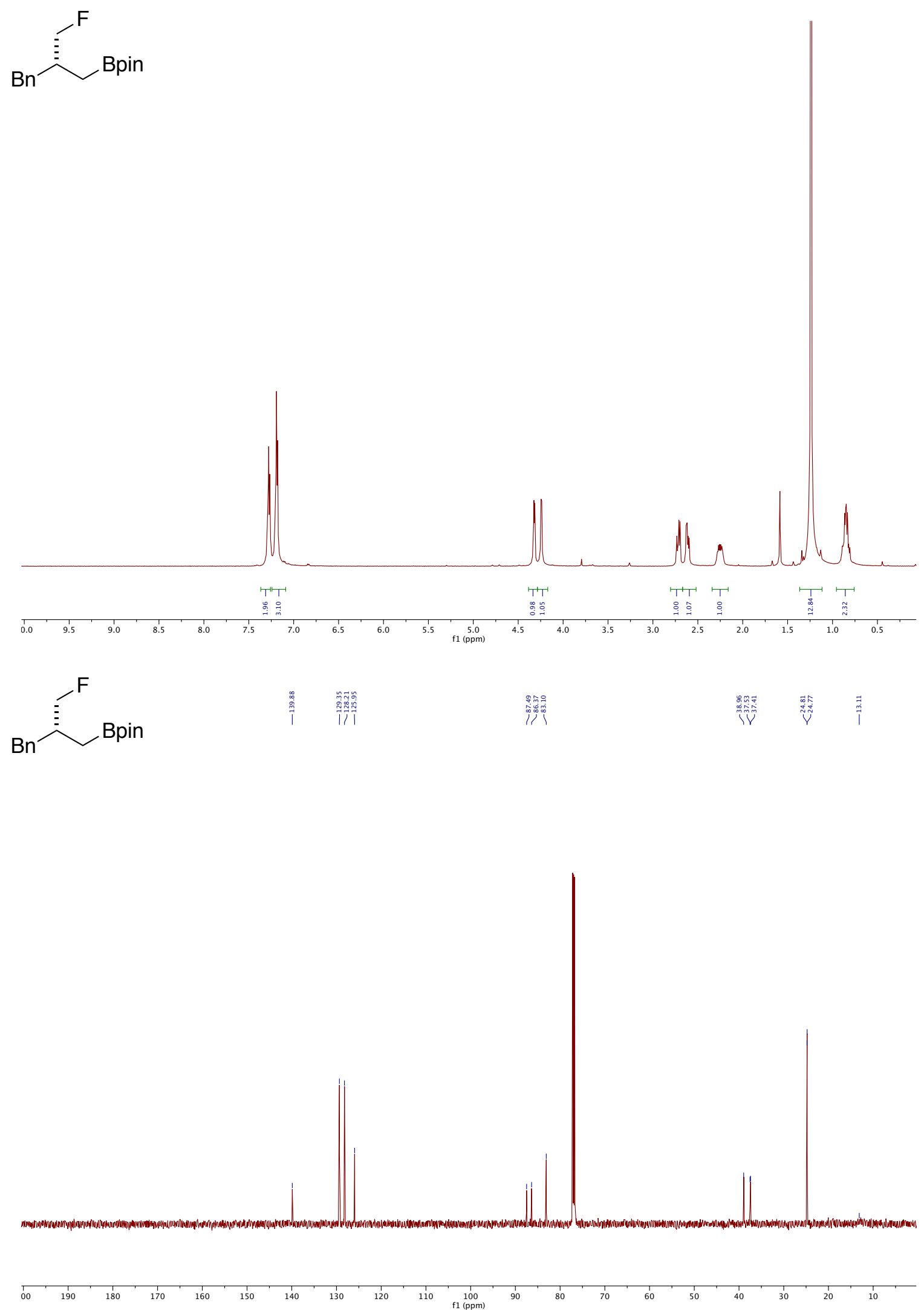

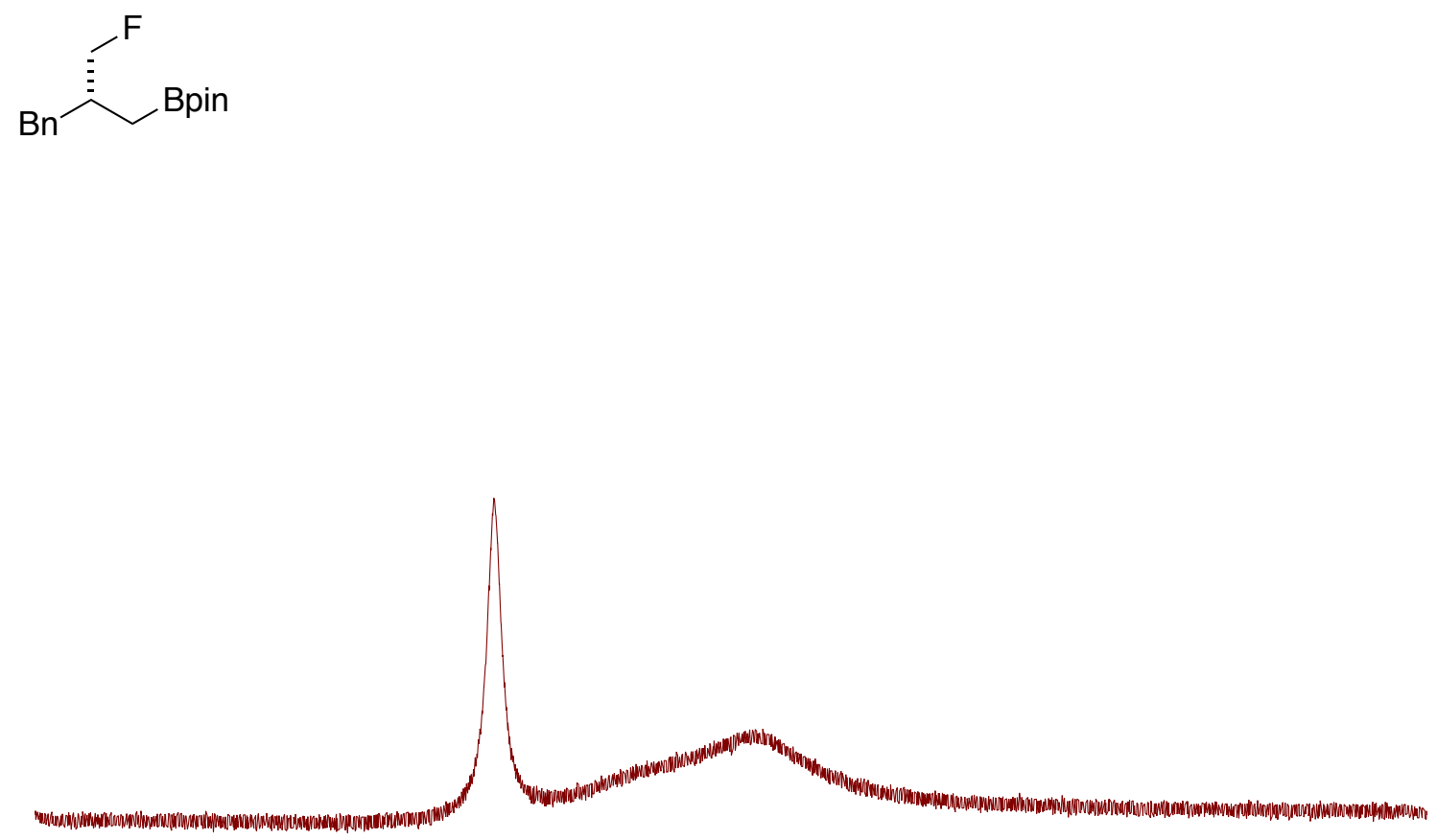

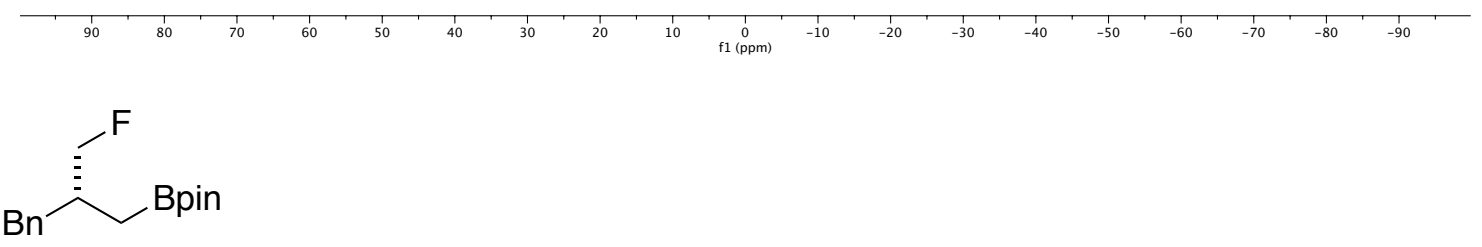

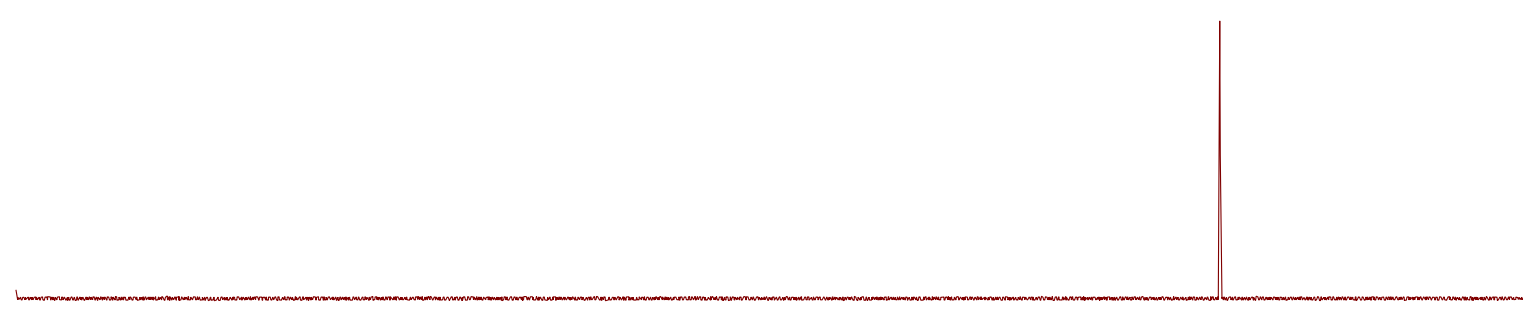

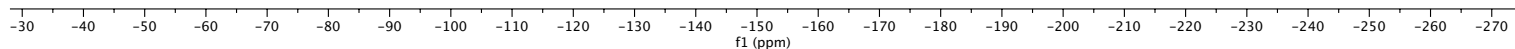



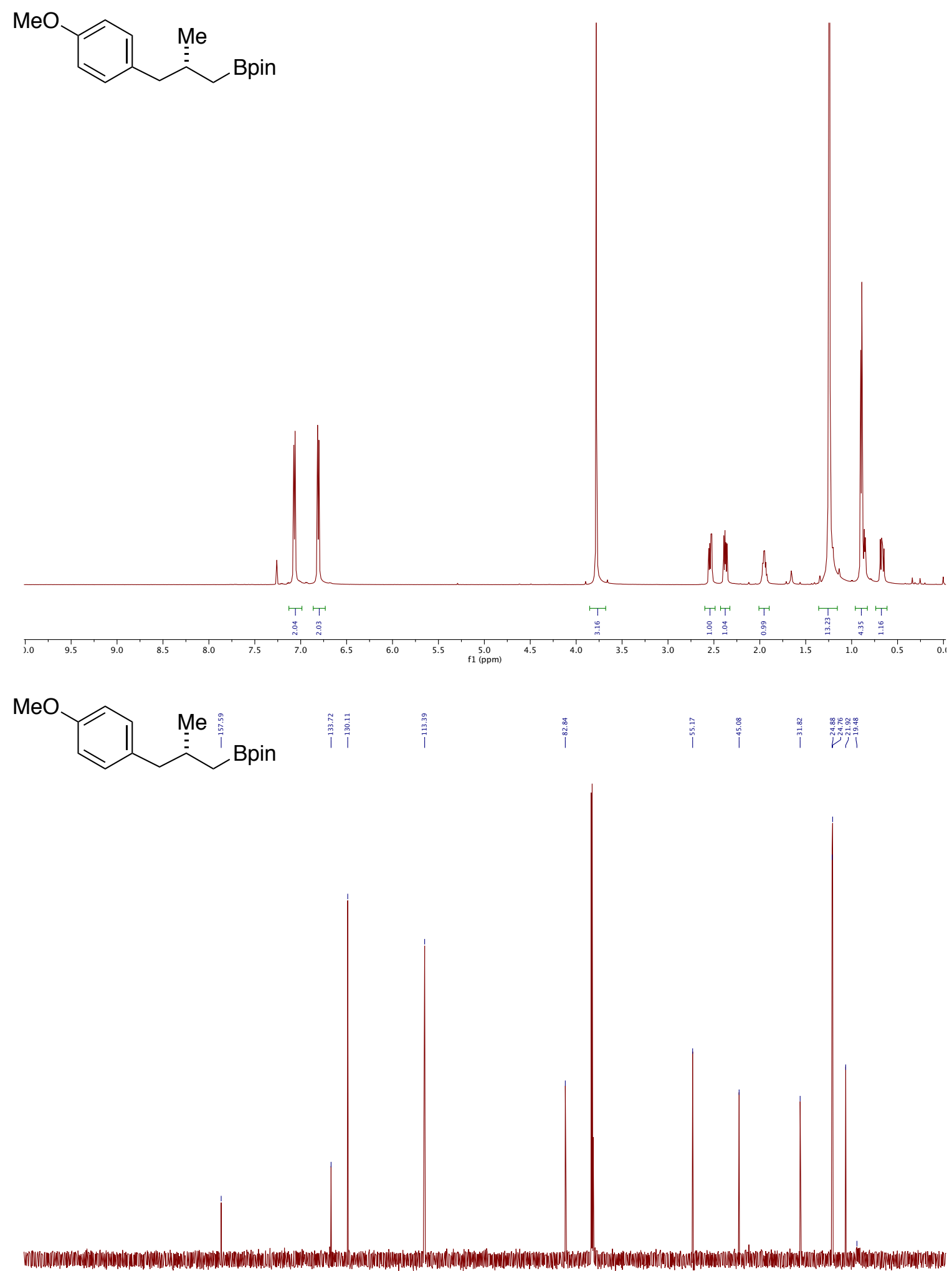

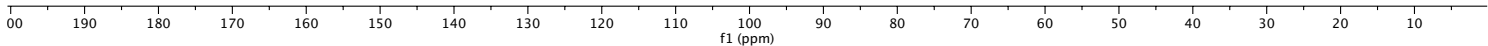



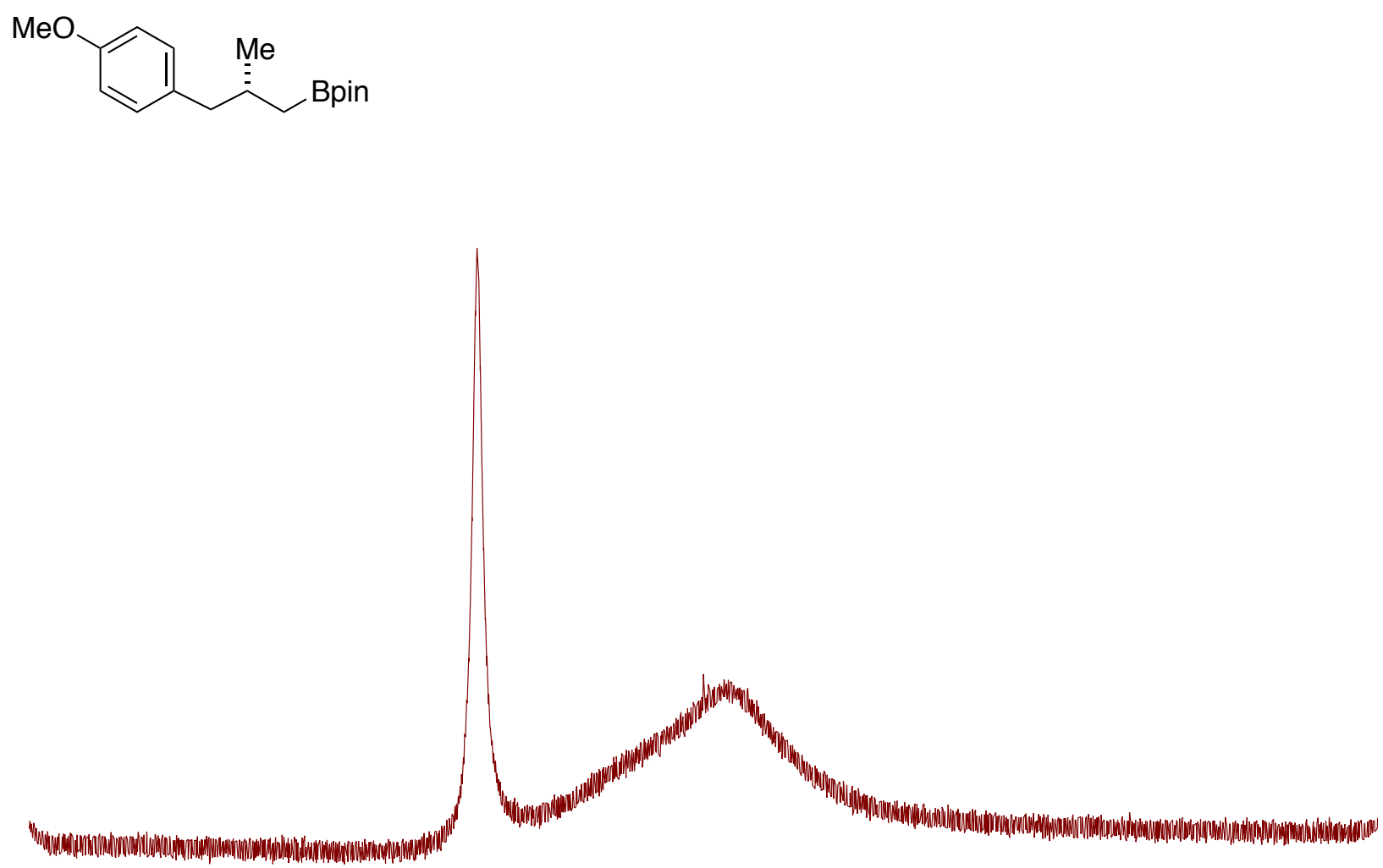

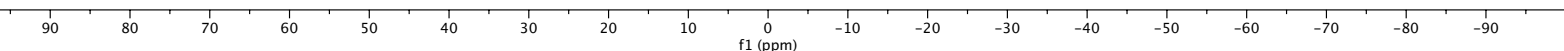



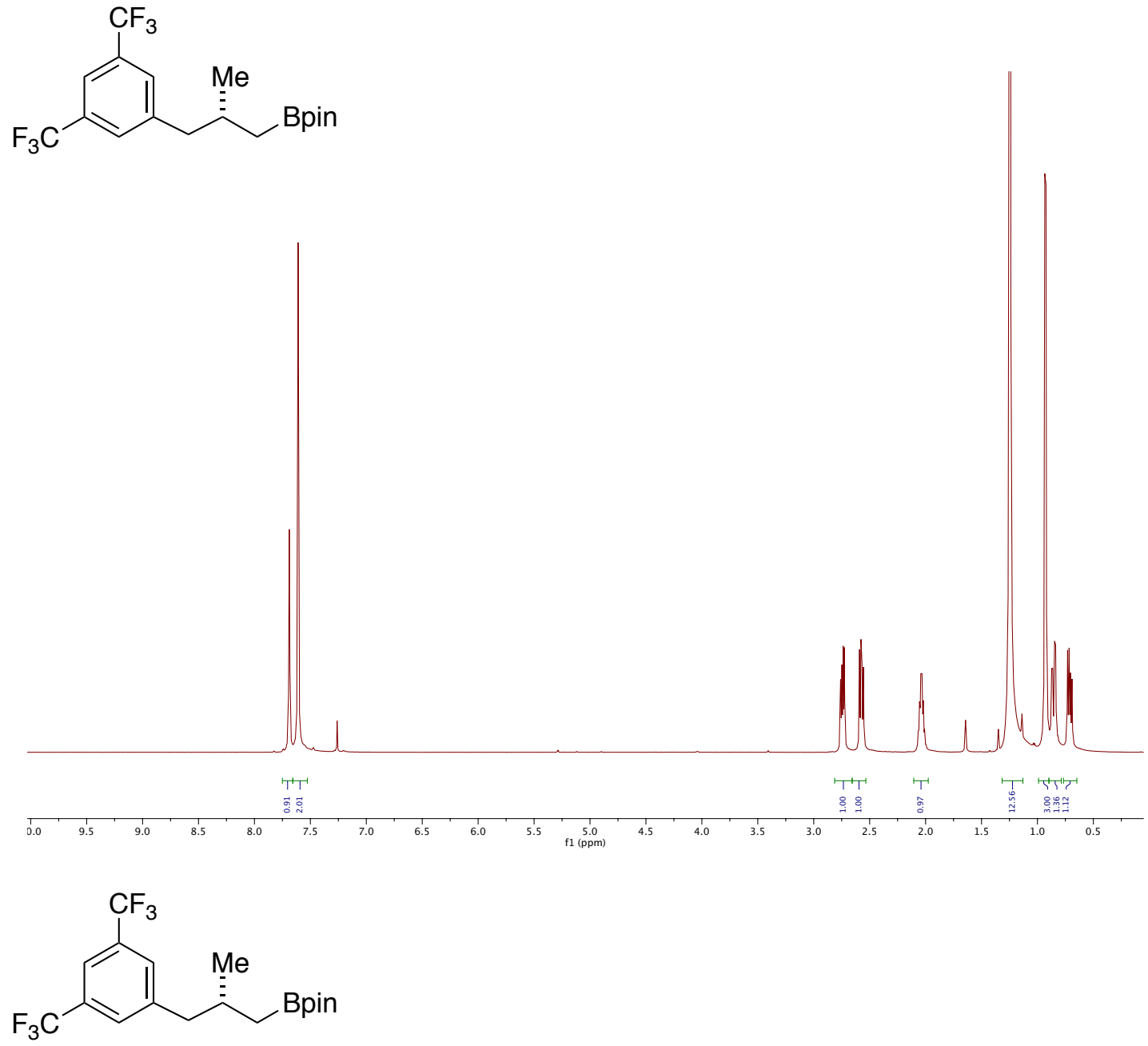

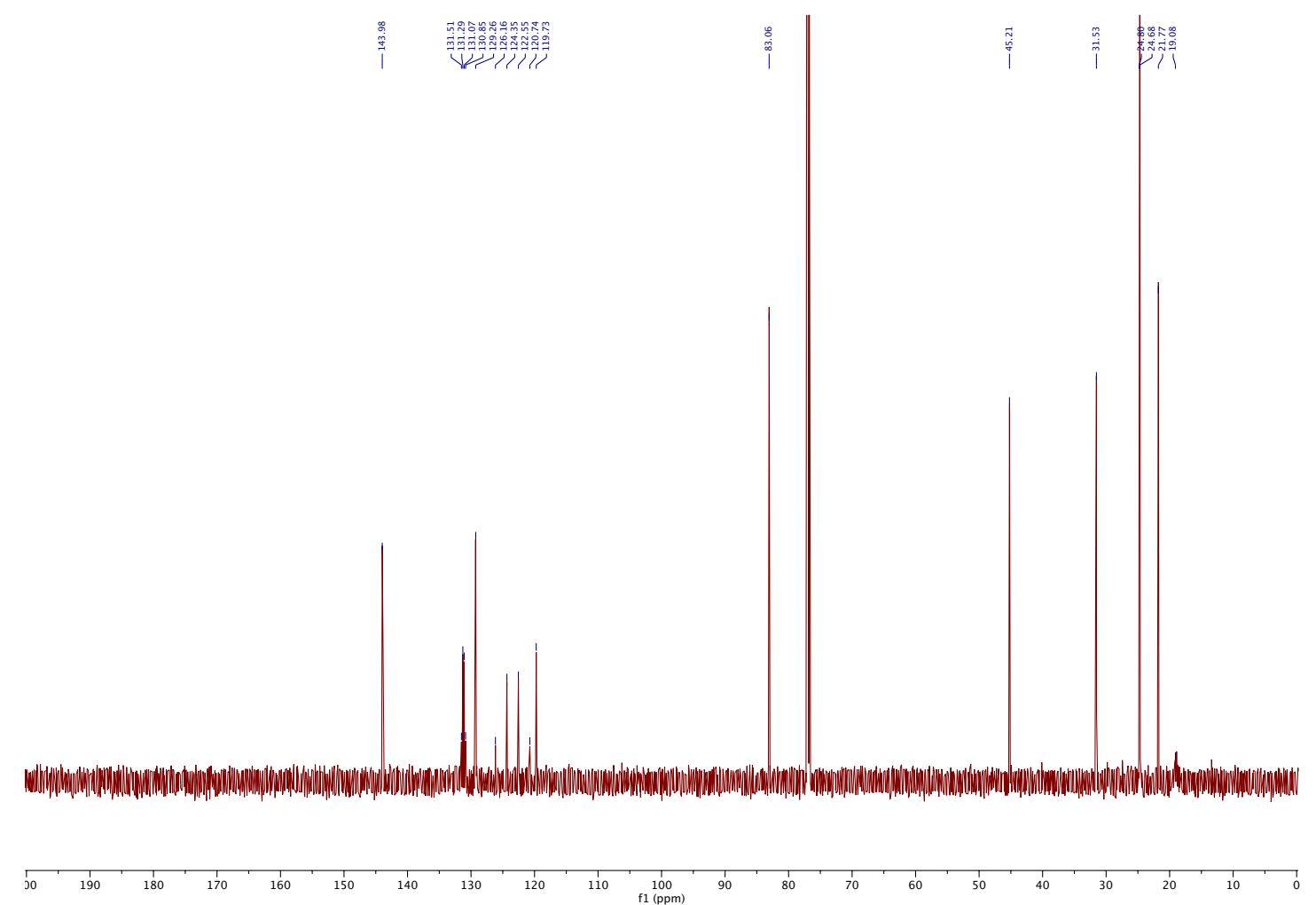<smiles>C[C@H](CCc1ccccc1)Cc1cc(C(F)(F)F)cc(C(F)(F)F)c1</smiles>
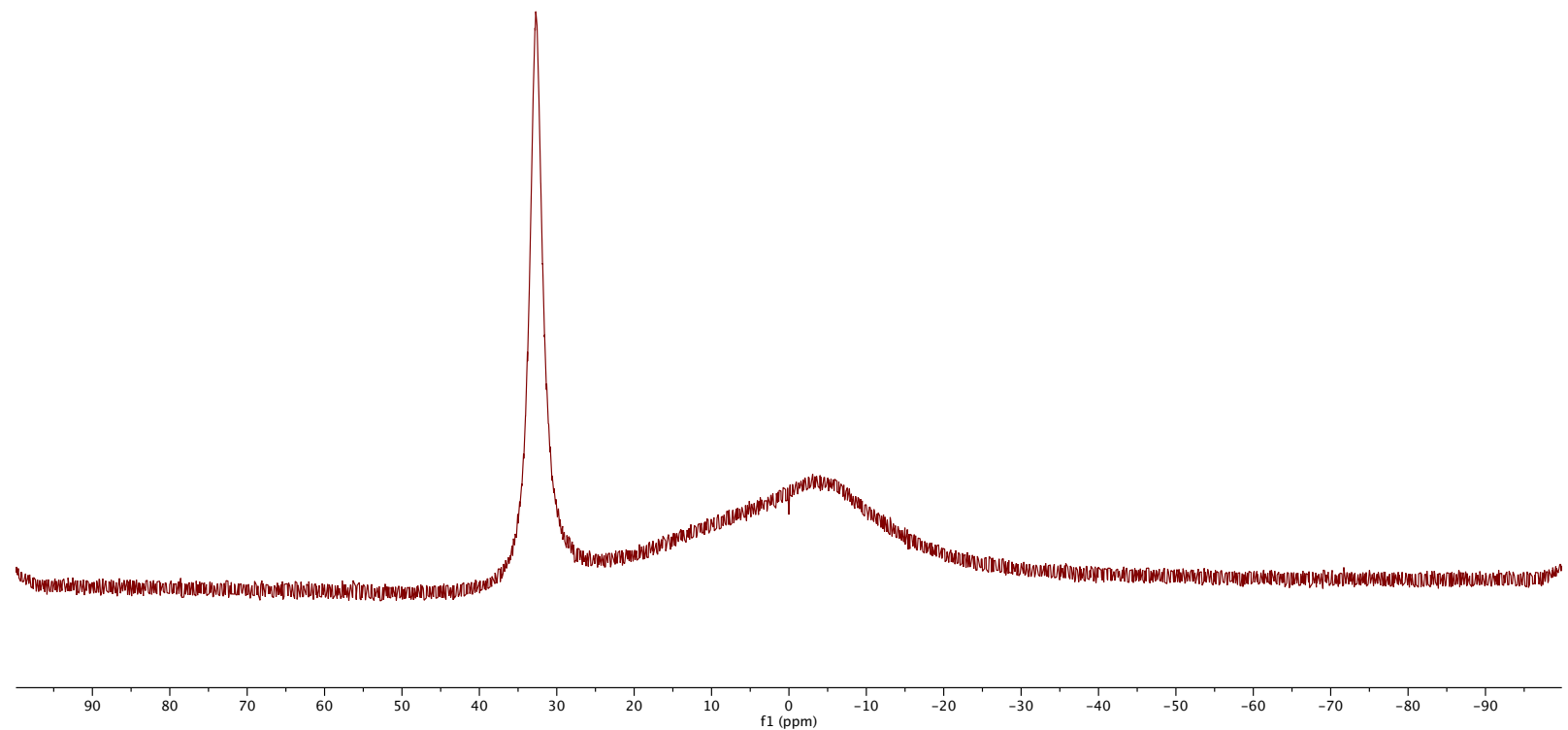

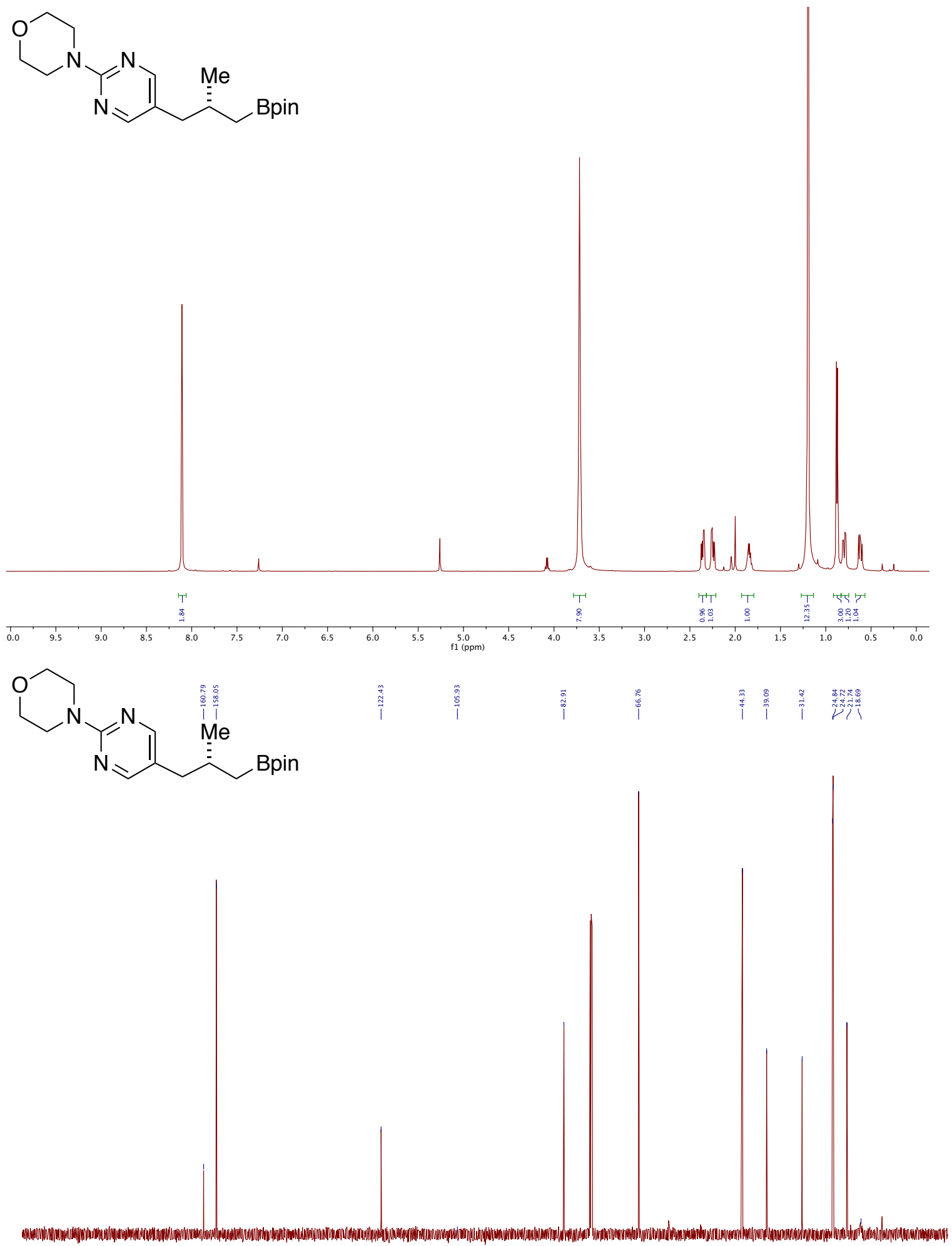

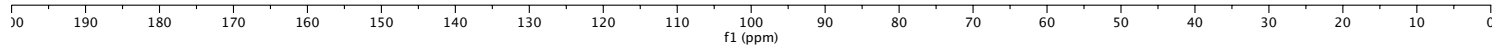




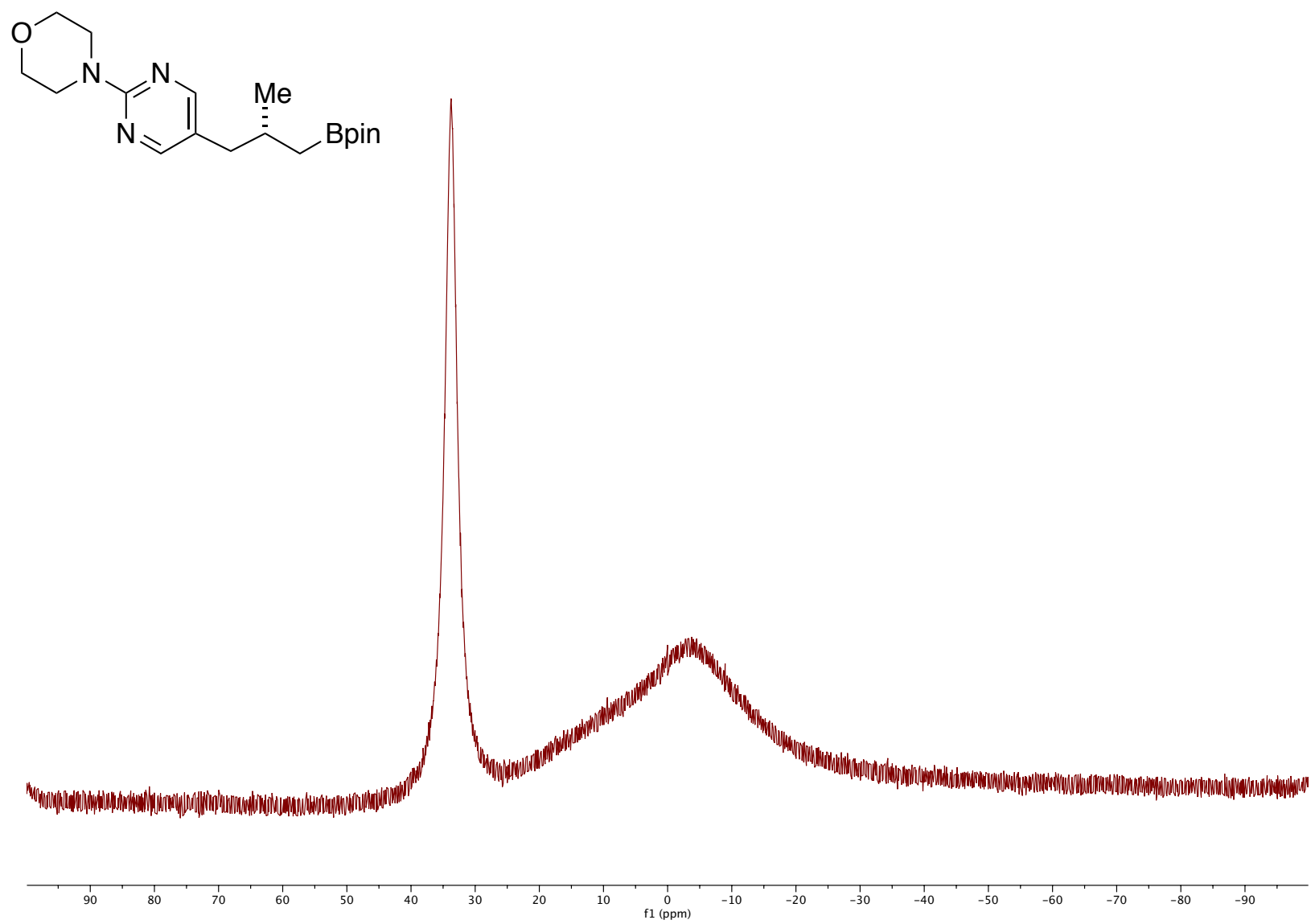

S102 

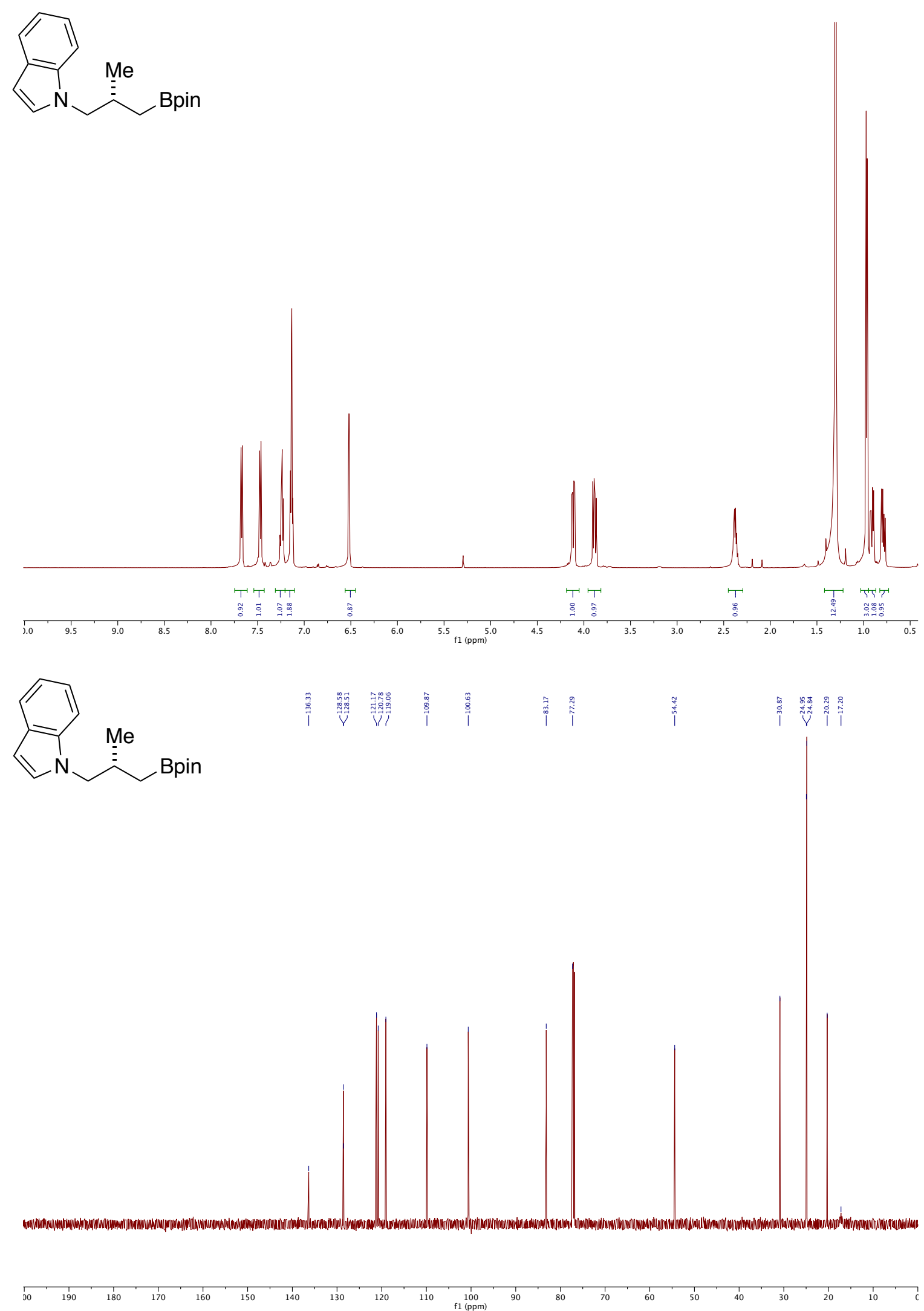


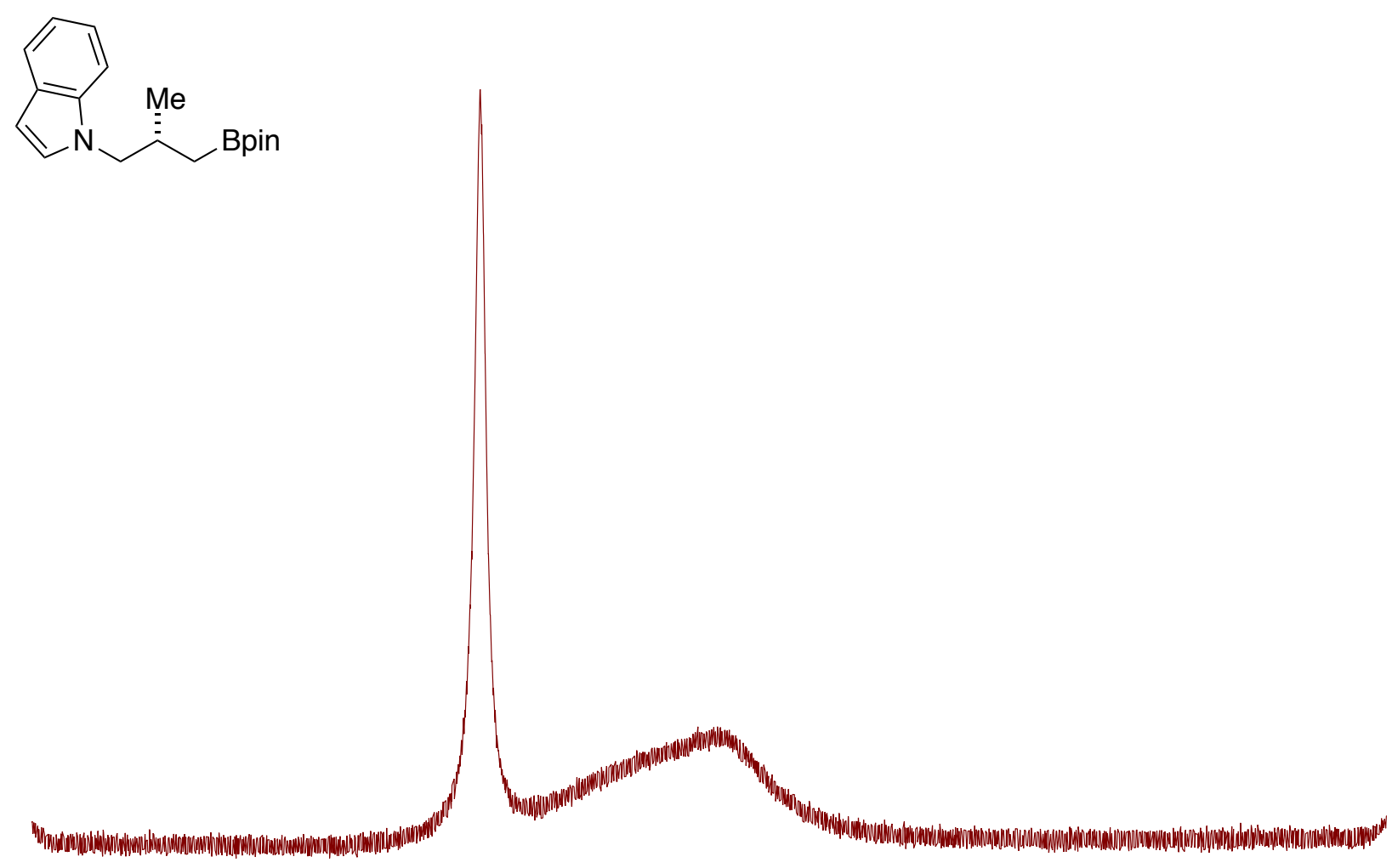



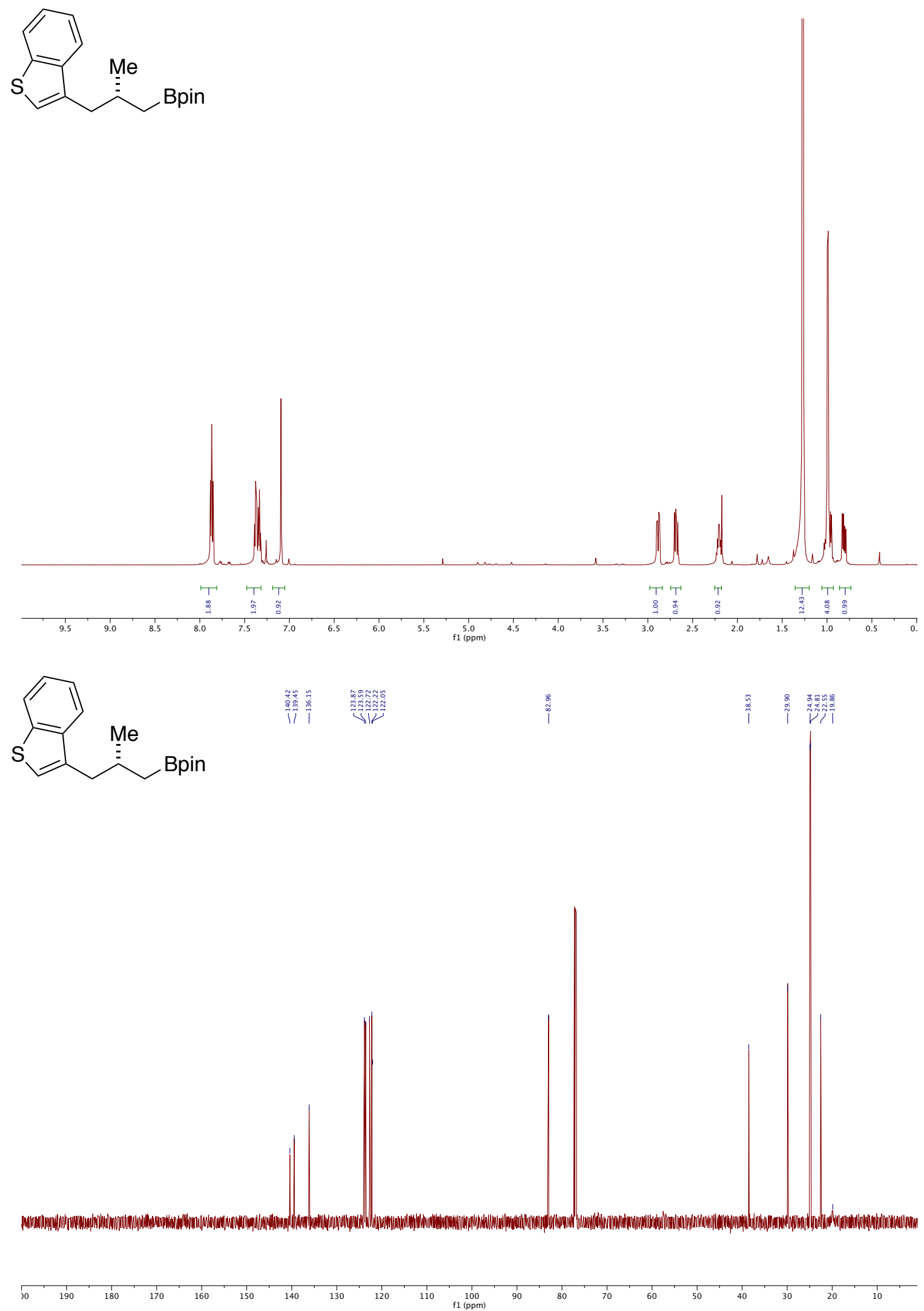

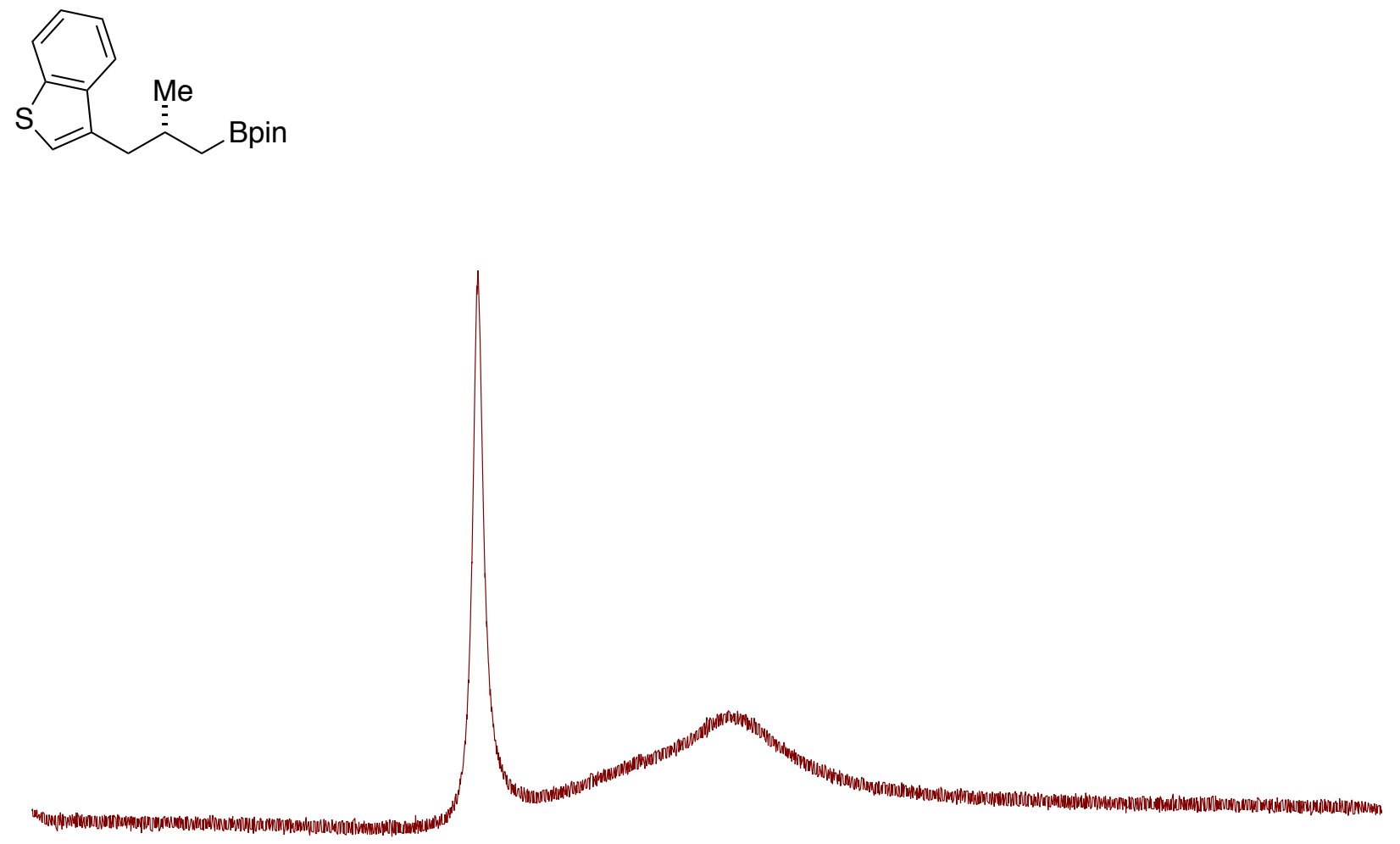

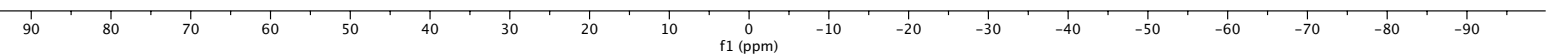


<smiles>CCCCCC(C)CCc1ccccc1</smiles>

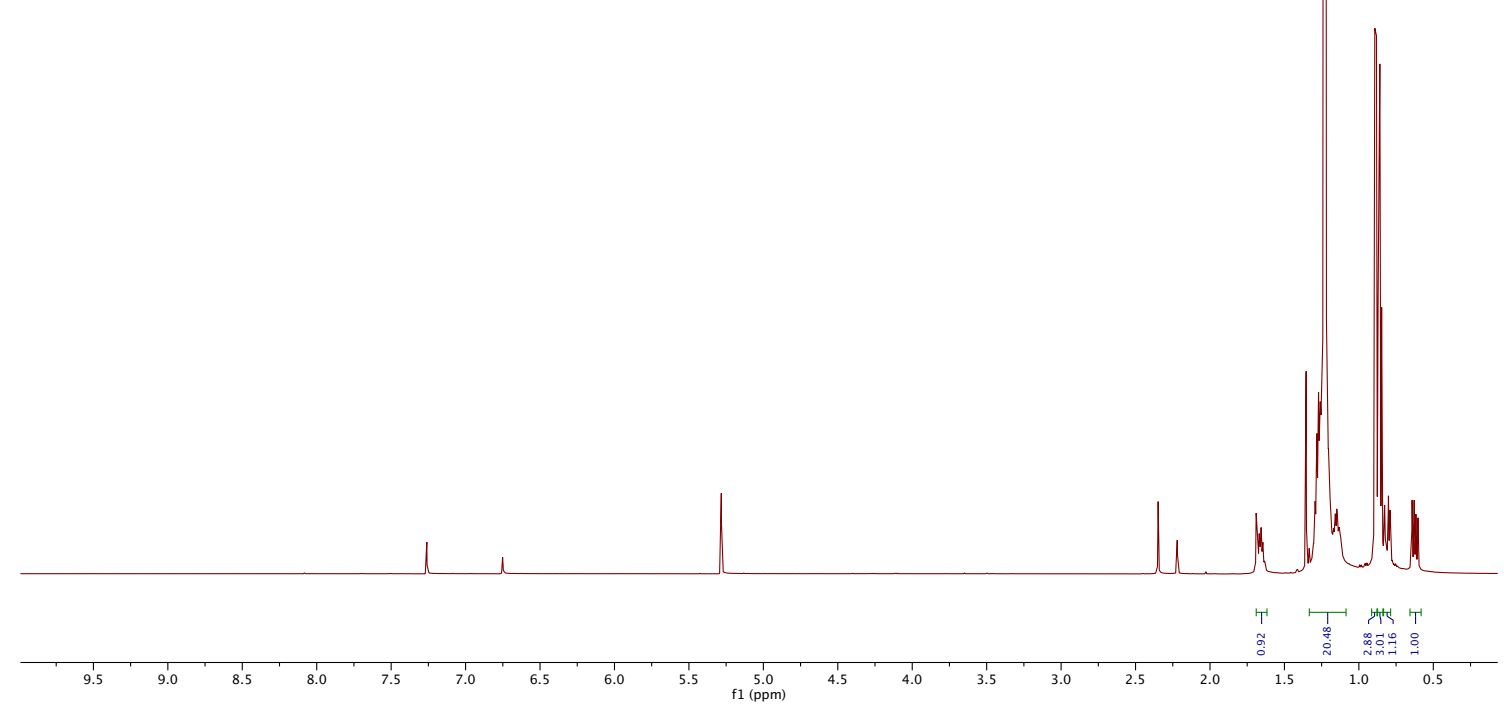<smiles>CCCCCC(C)CCc1ccccc1</smiles>

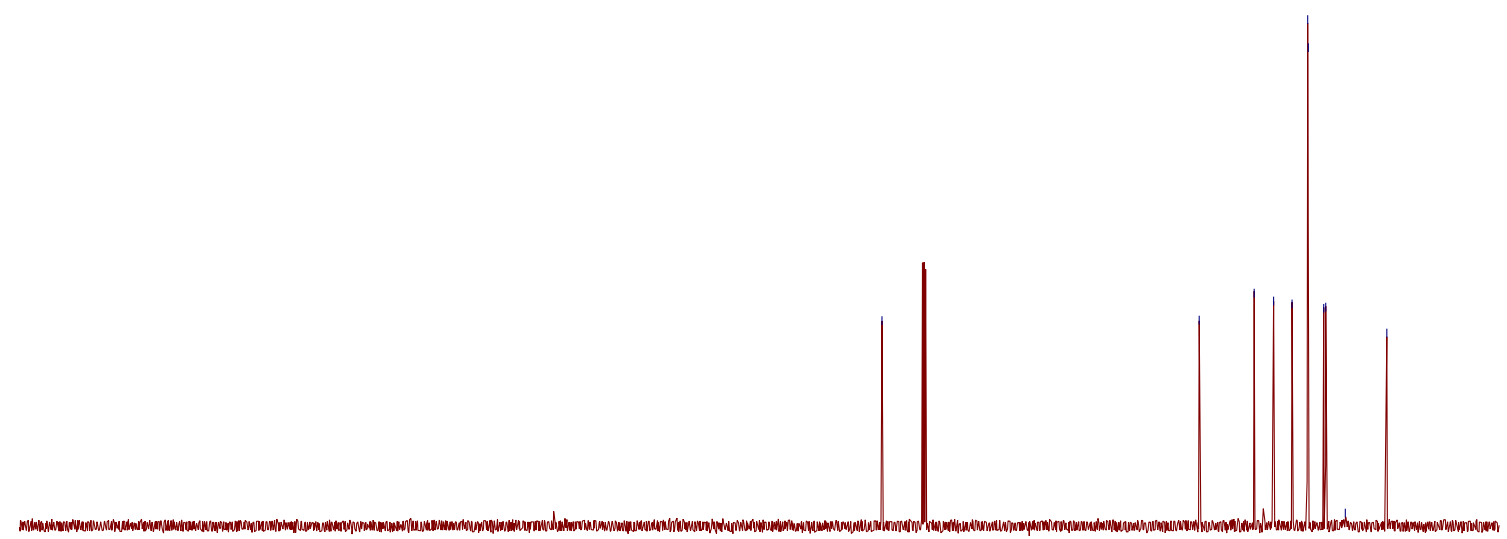

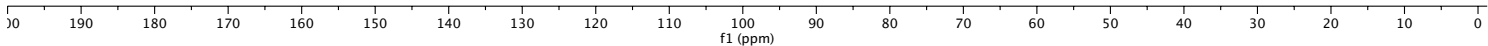



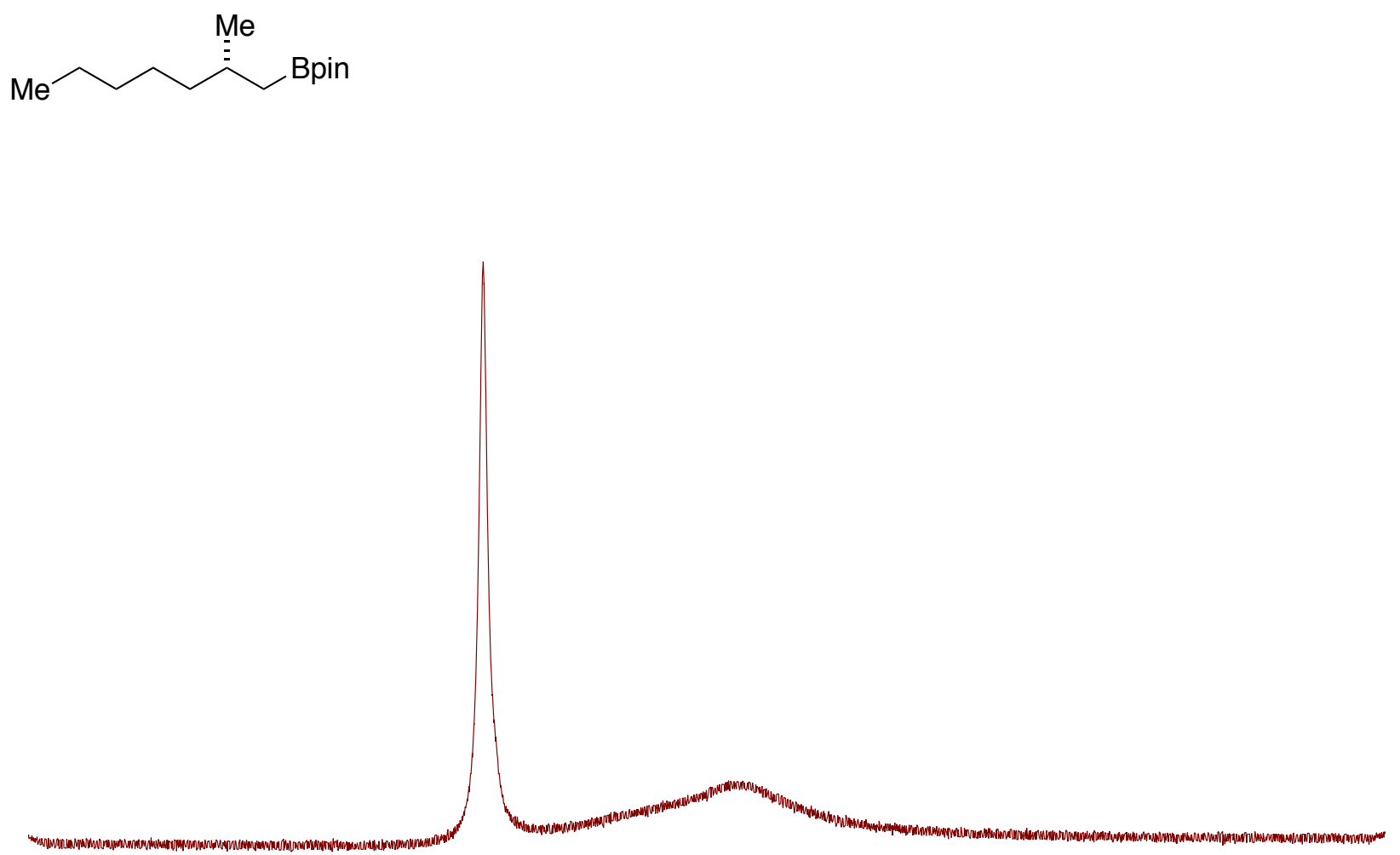

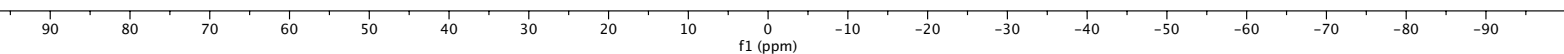



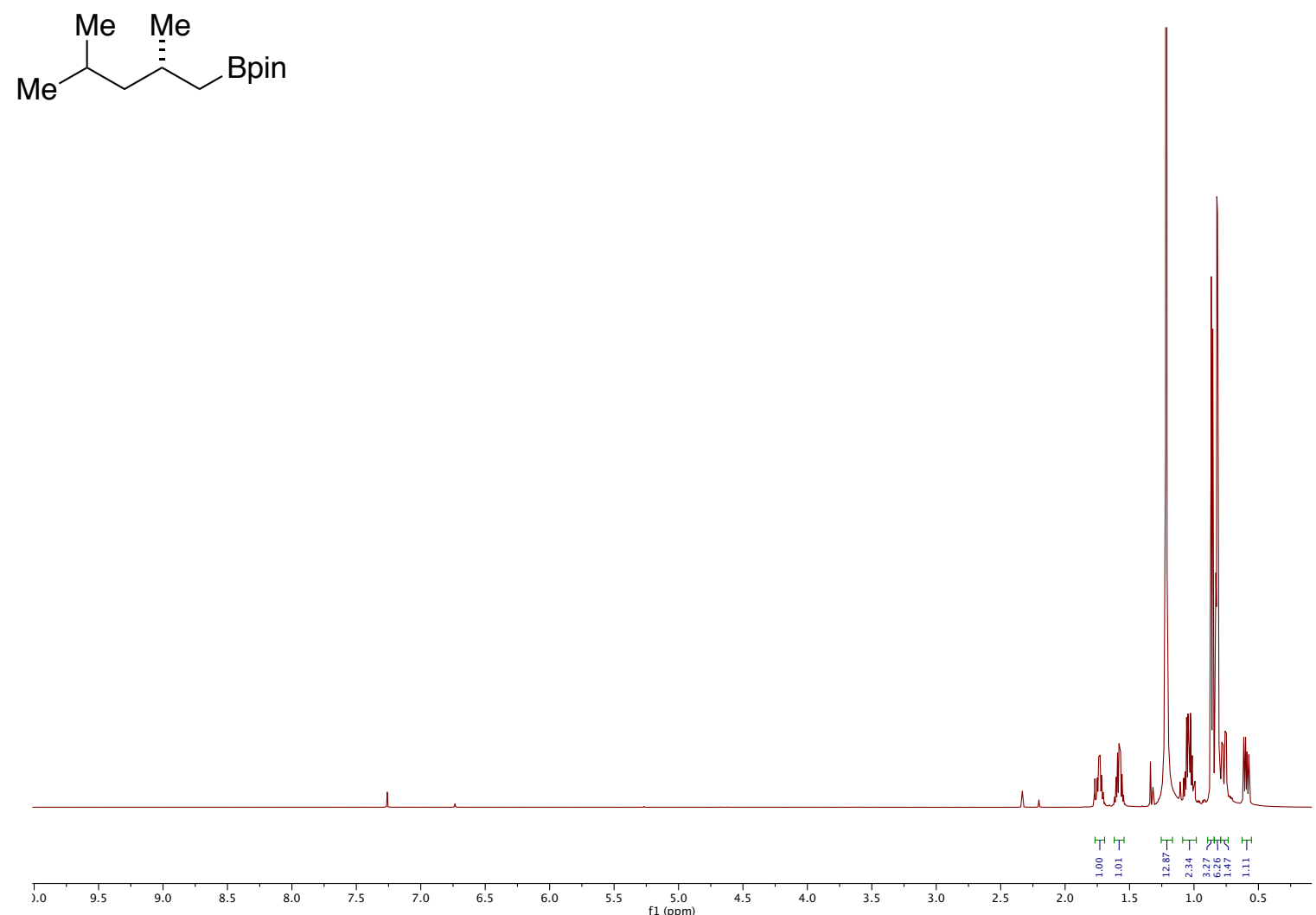
$\overbrace{\text { Bpin }}^{M e}$

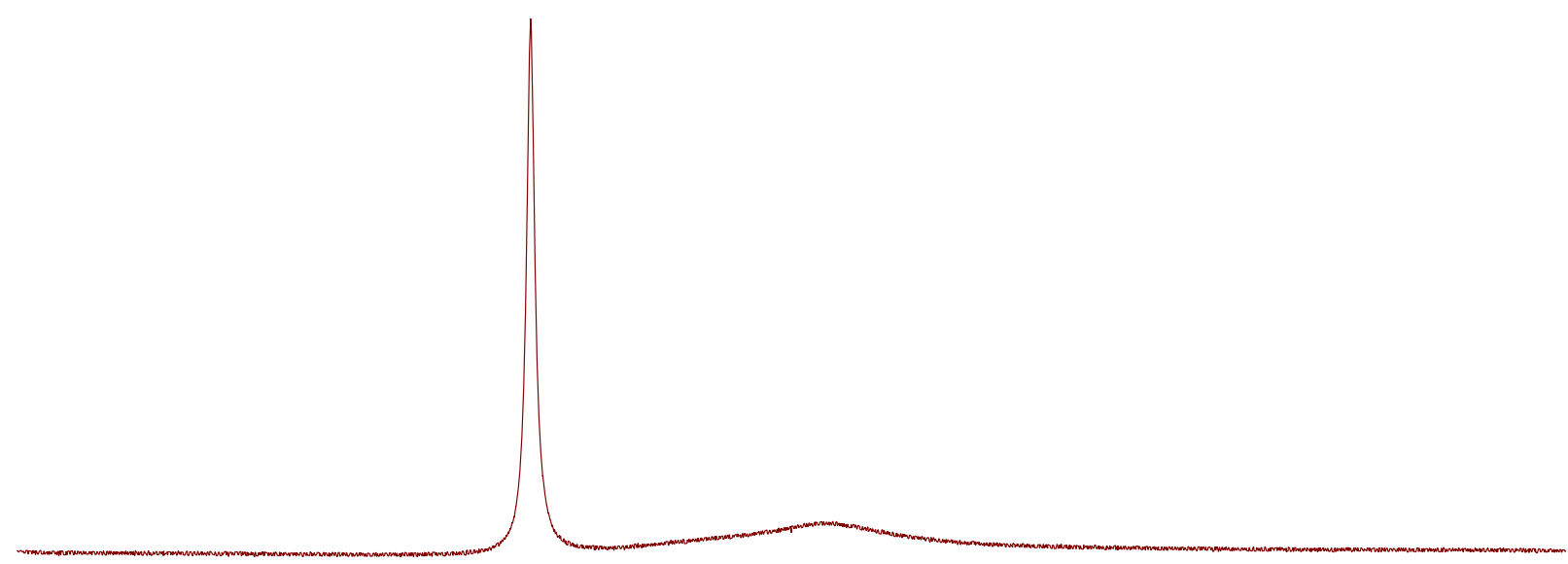


<smiles>CC(CCc1ccccc1)CCc1ccccc1</smiles>
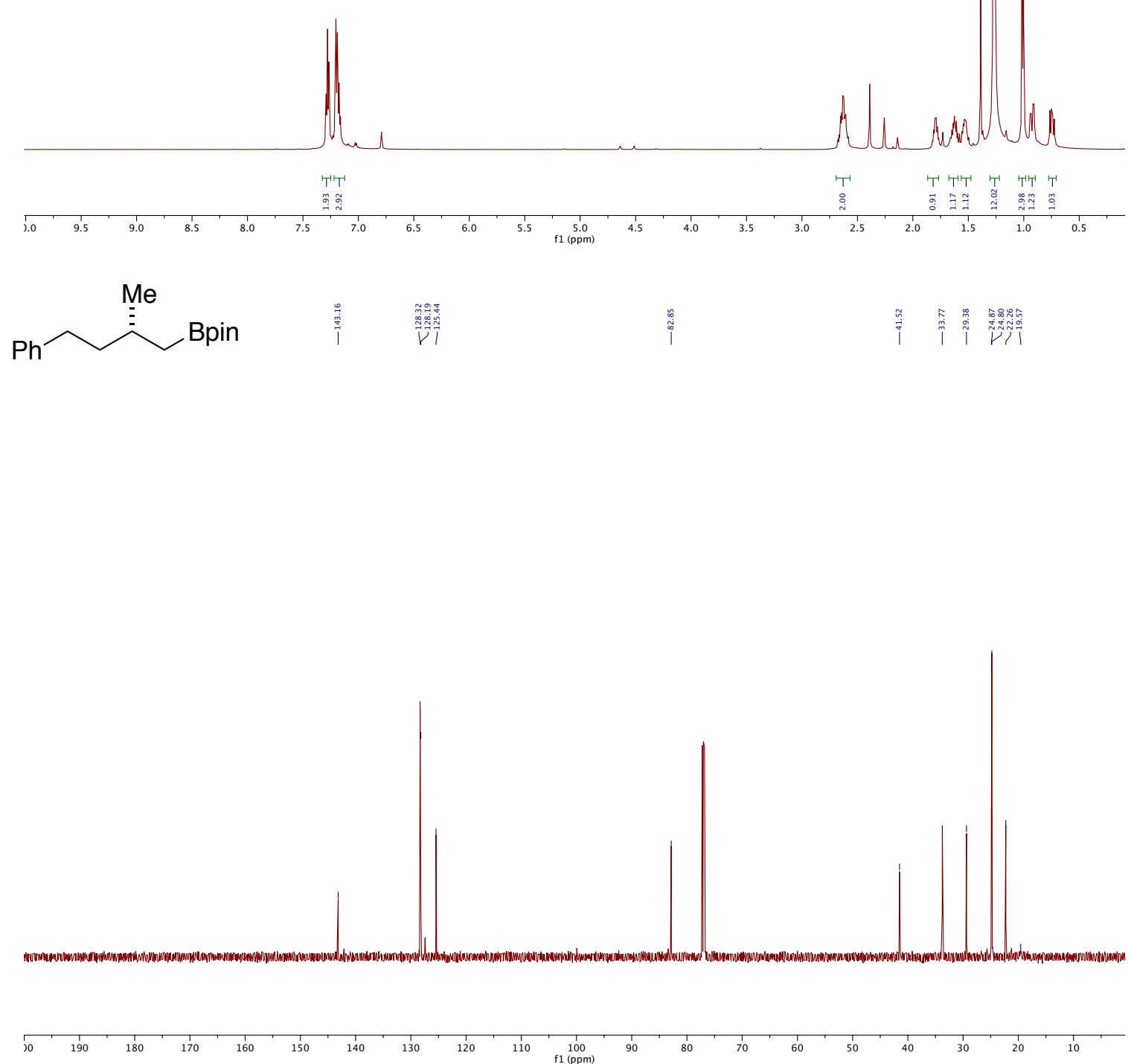
<smiles>CC(CCc1ccccc1)CCc1ccccc1</smiles>

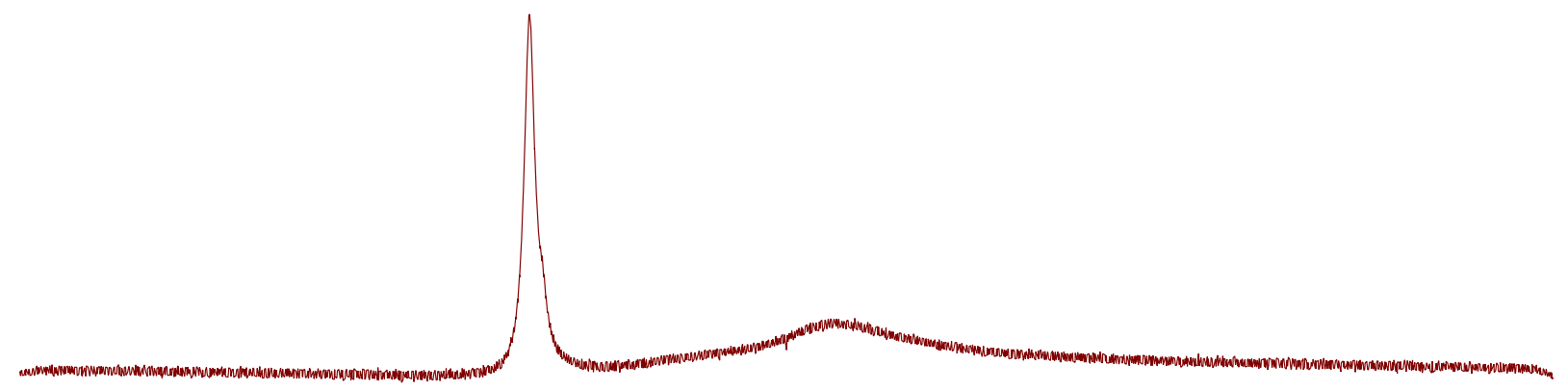


TrO $\overbrace{}^{\mathrm{Me}}$ Bpin
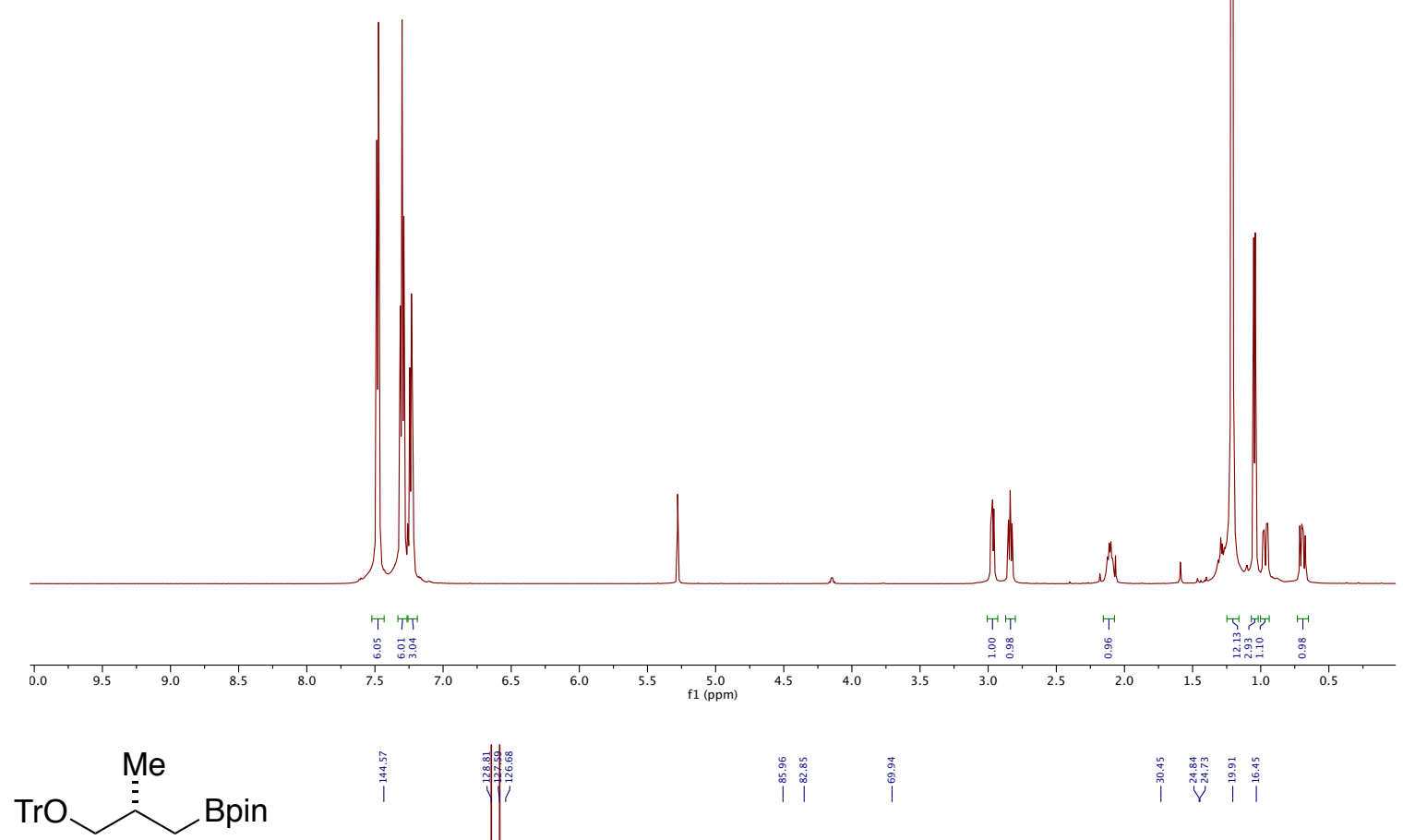

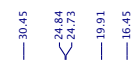

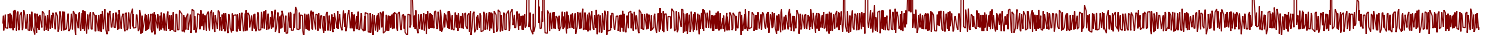

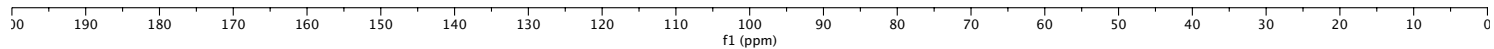


TrO $\sim_{B \text { Bin }}^{\mathrm{Me}}$
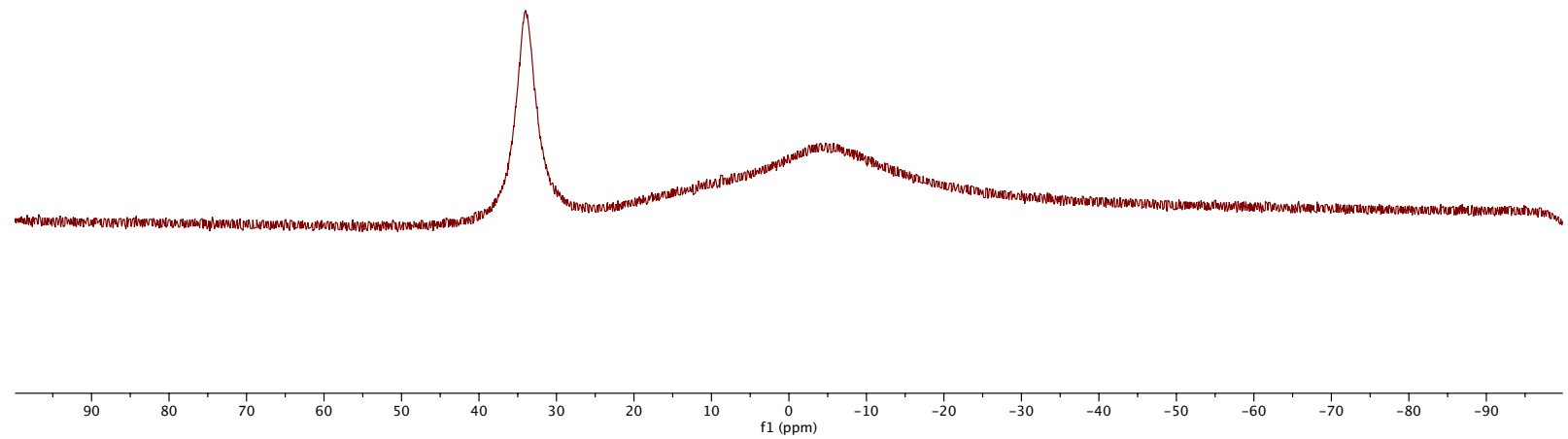

S114 

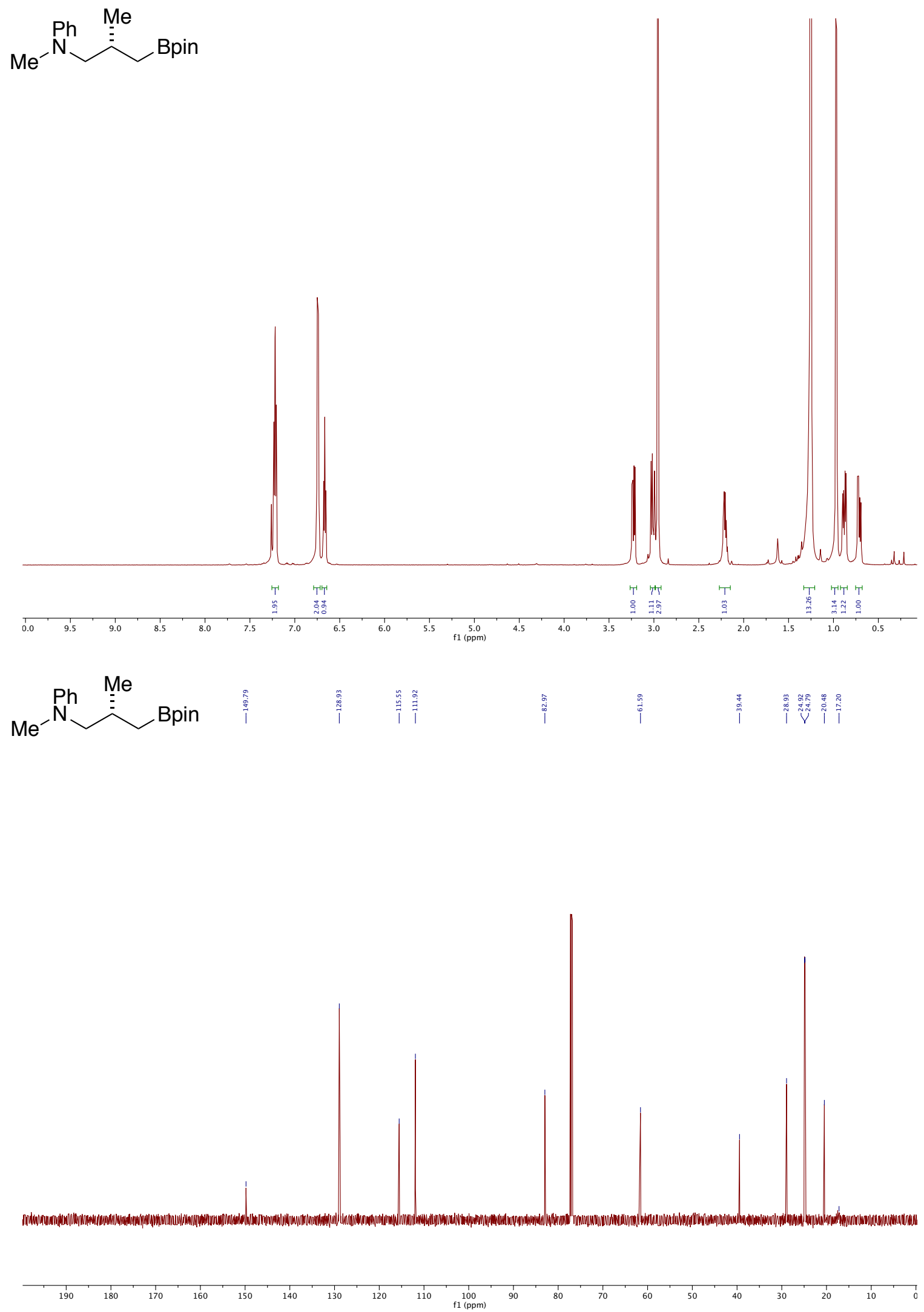


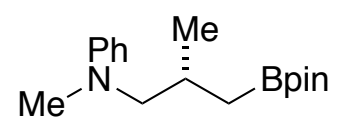

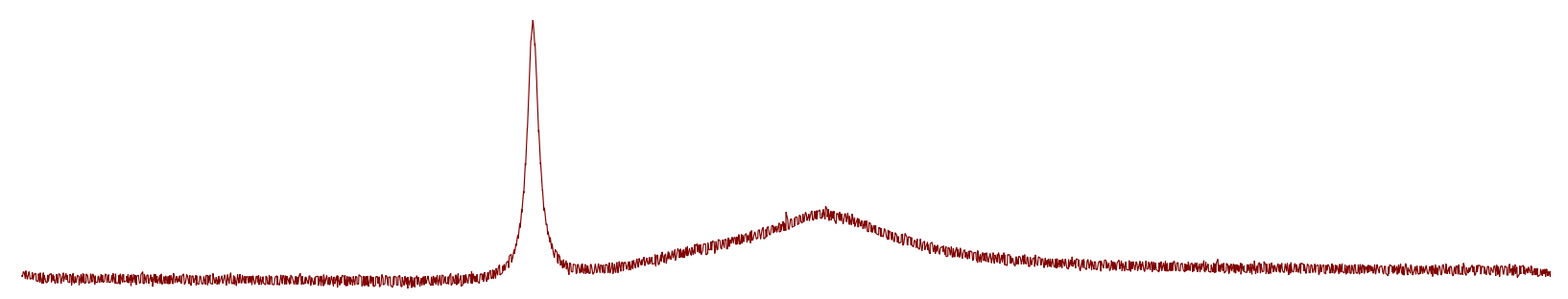




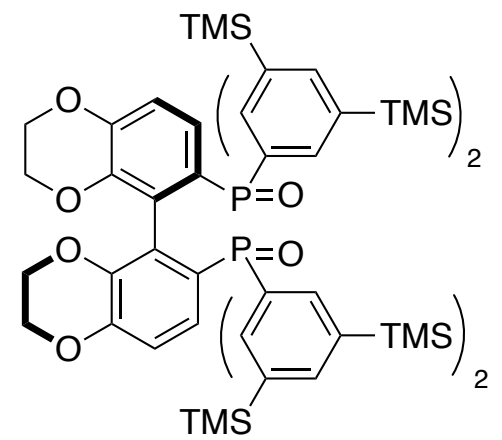




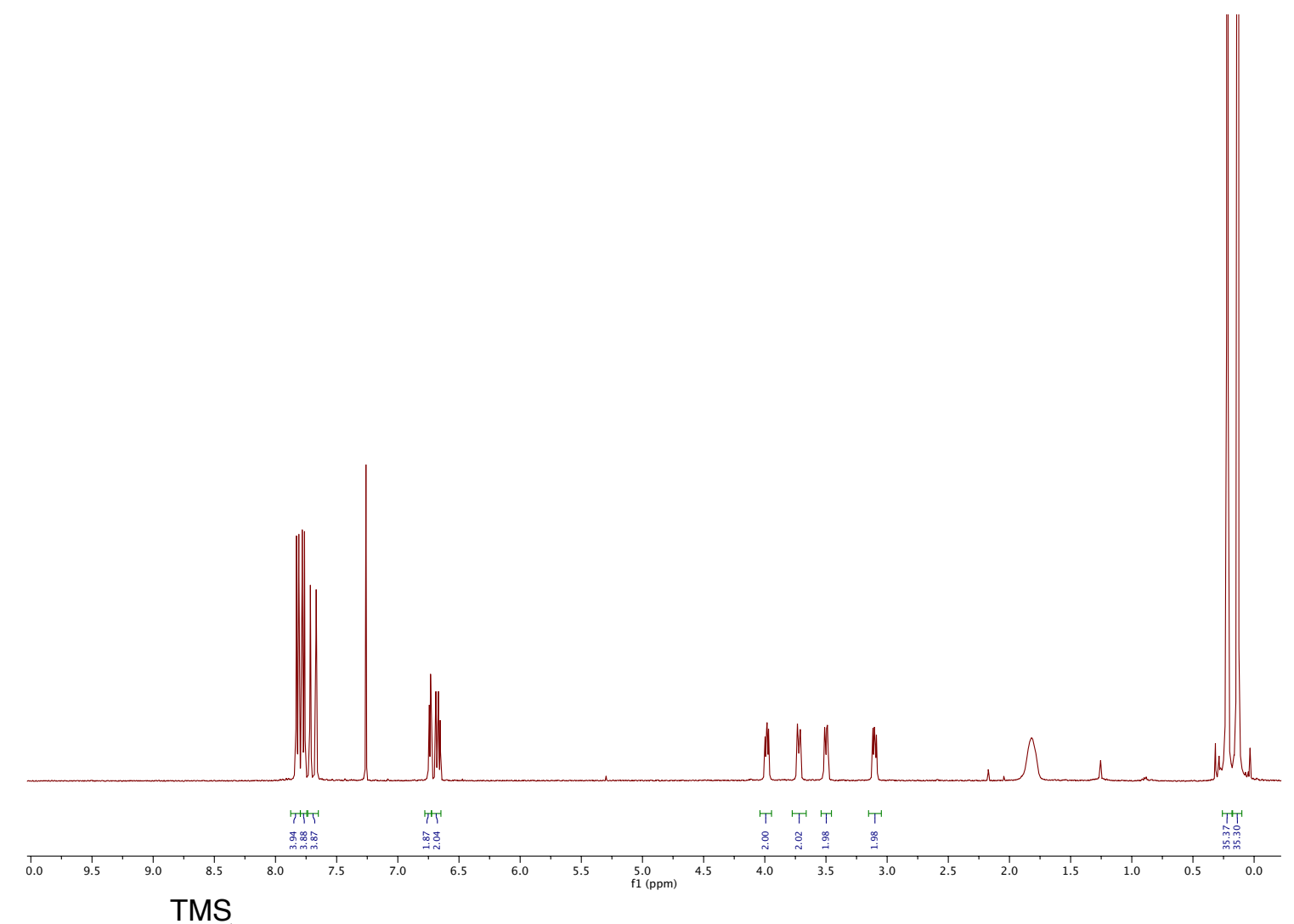



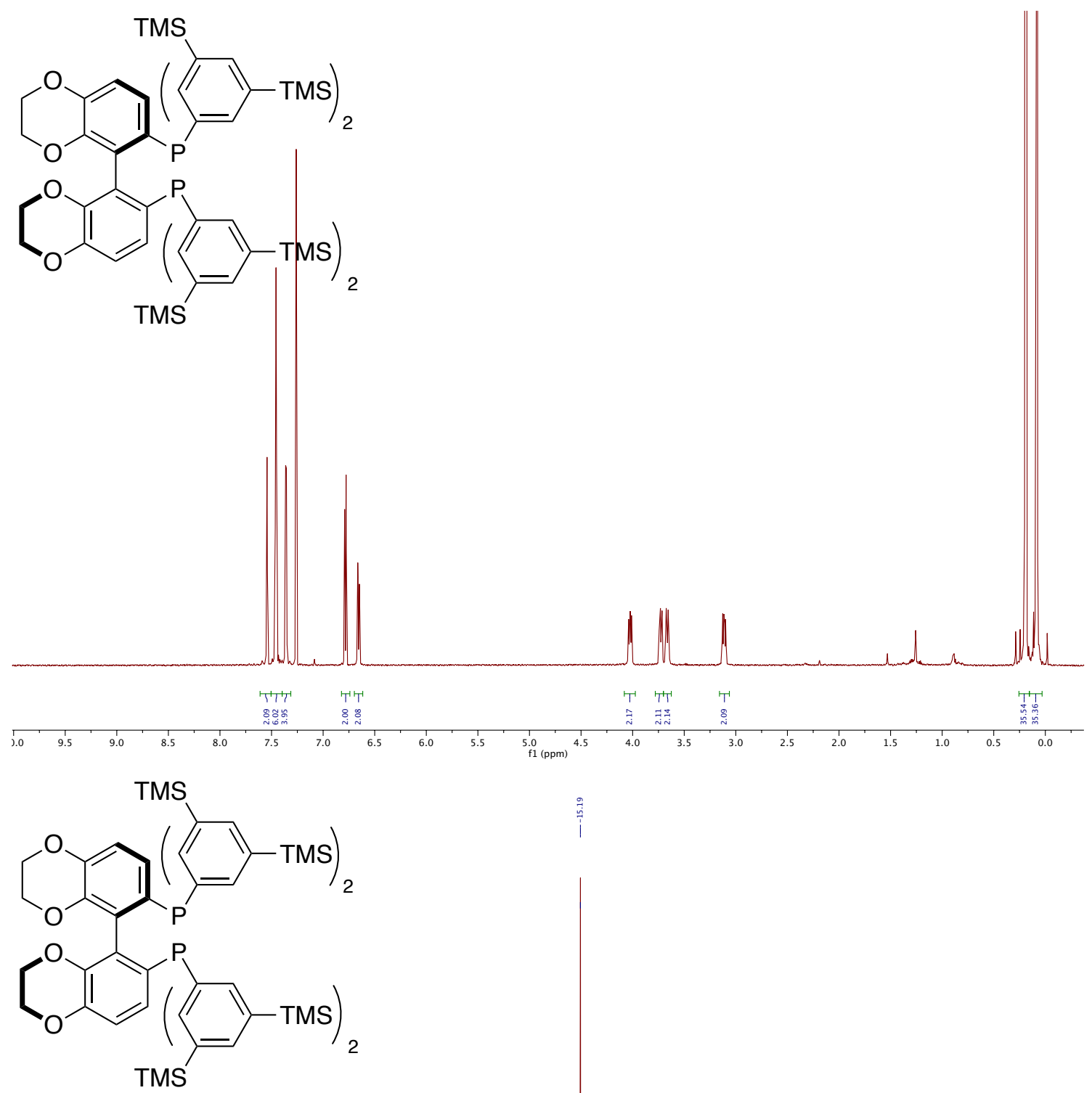

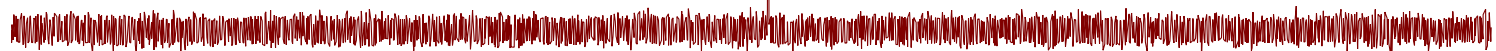

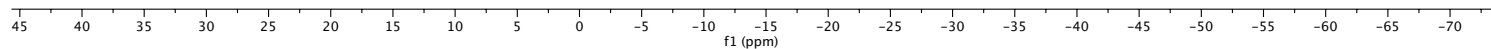



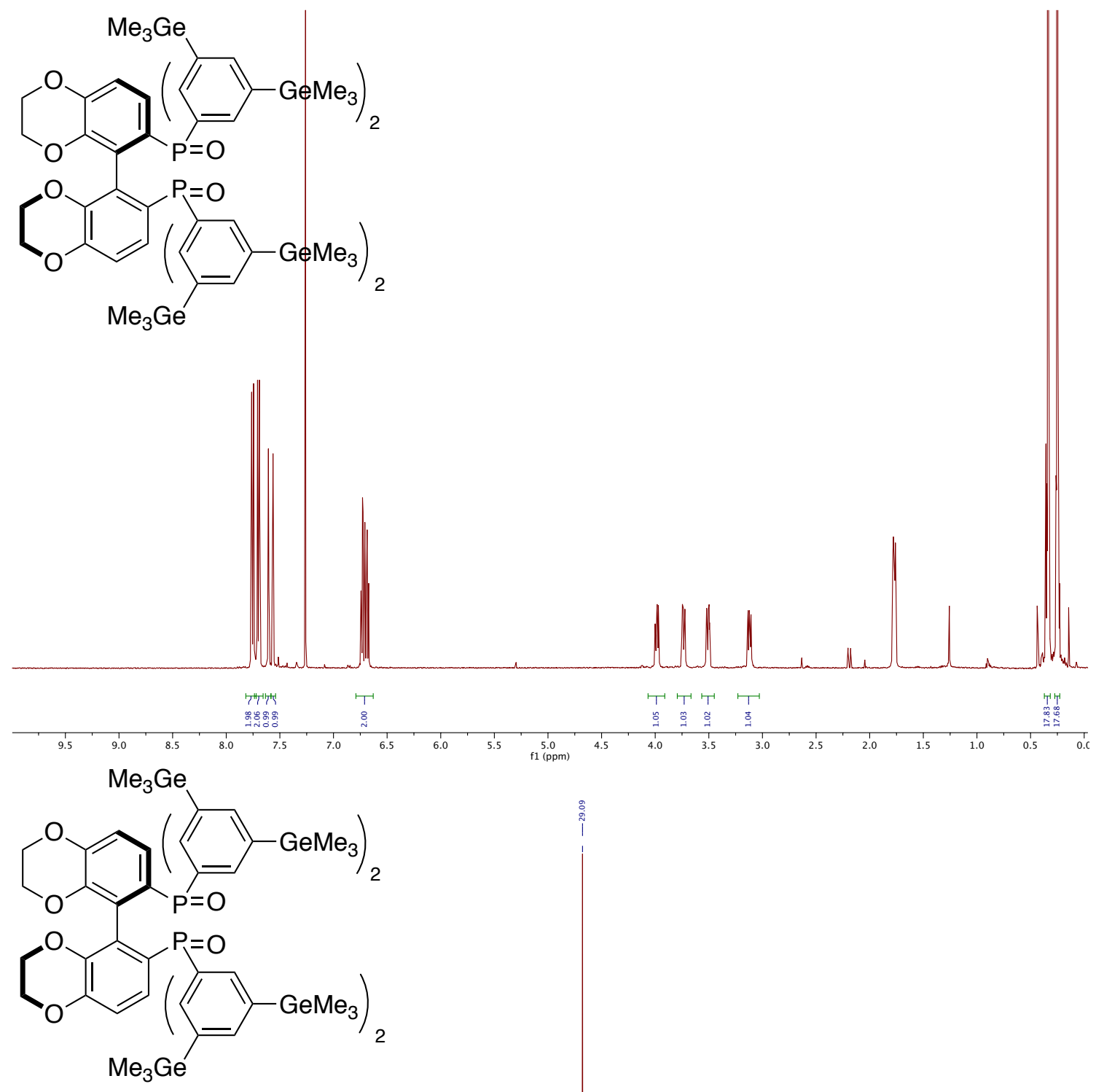

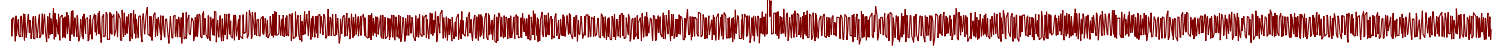

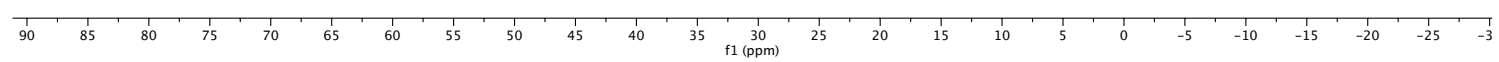



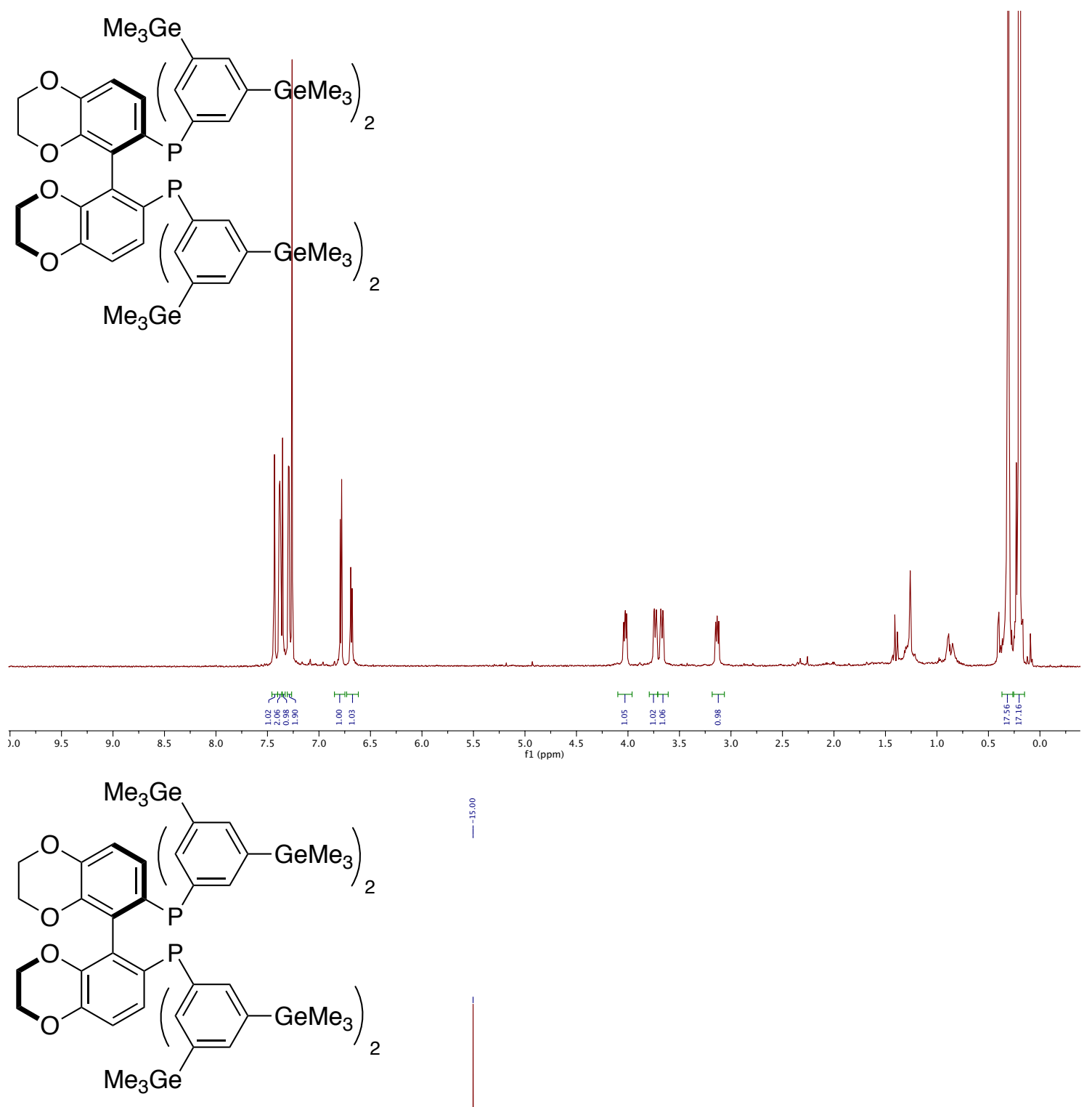

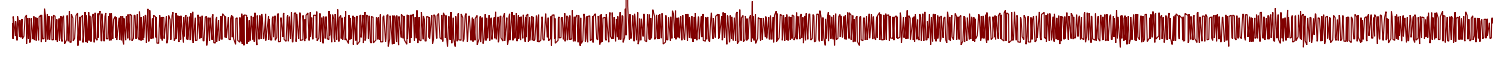

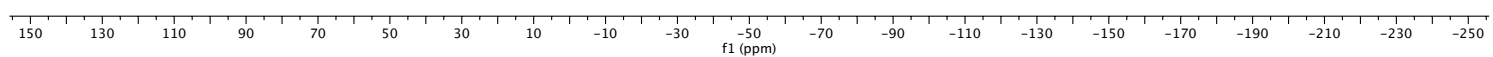


<smiles>COc1c(C(C)(C)C)cc(Br)cc1S(C)(=O)=O</smiles>
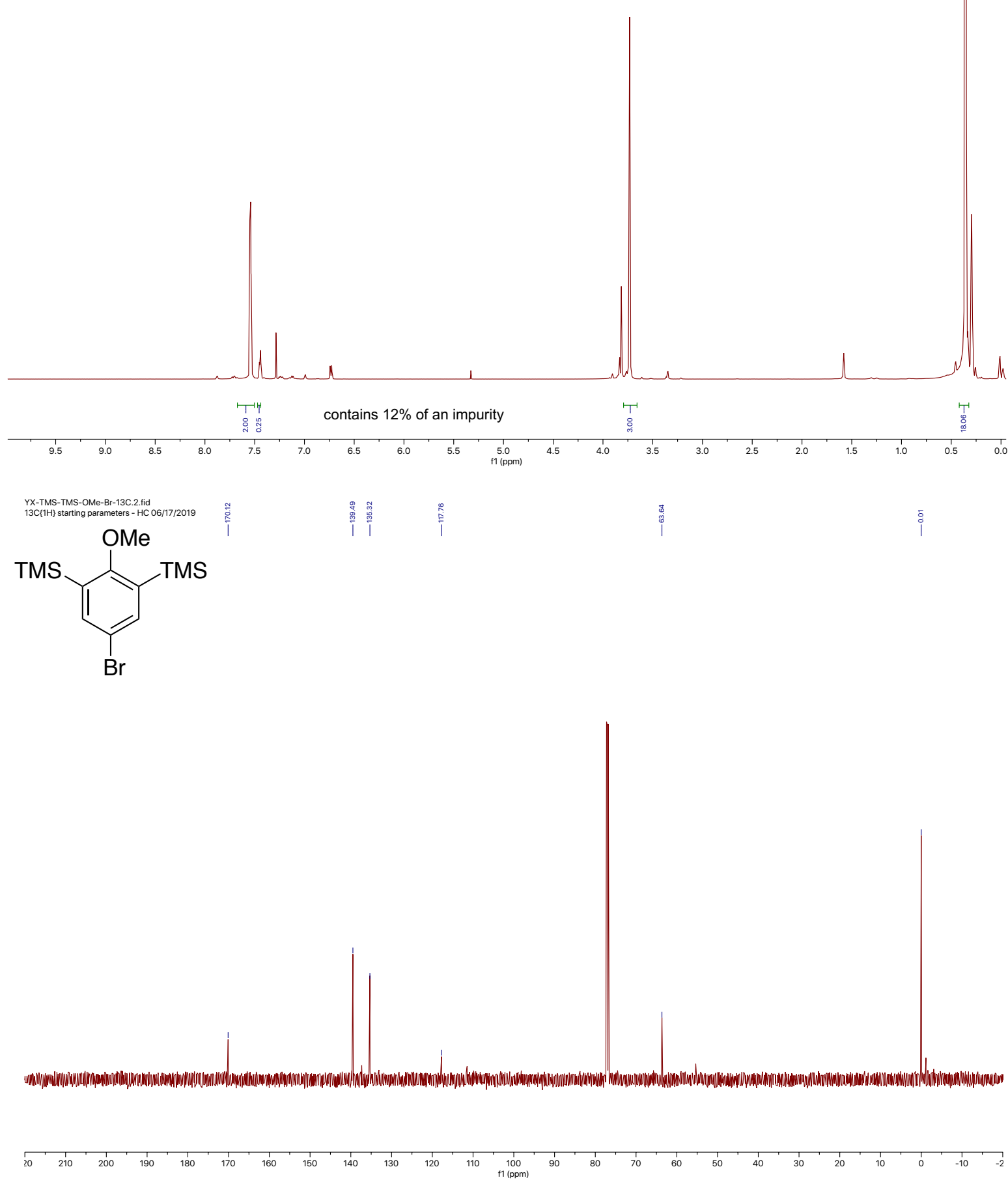

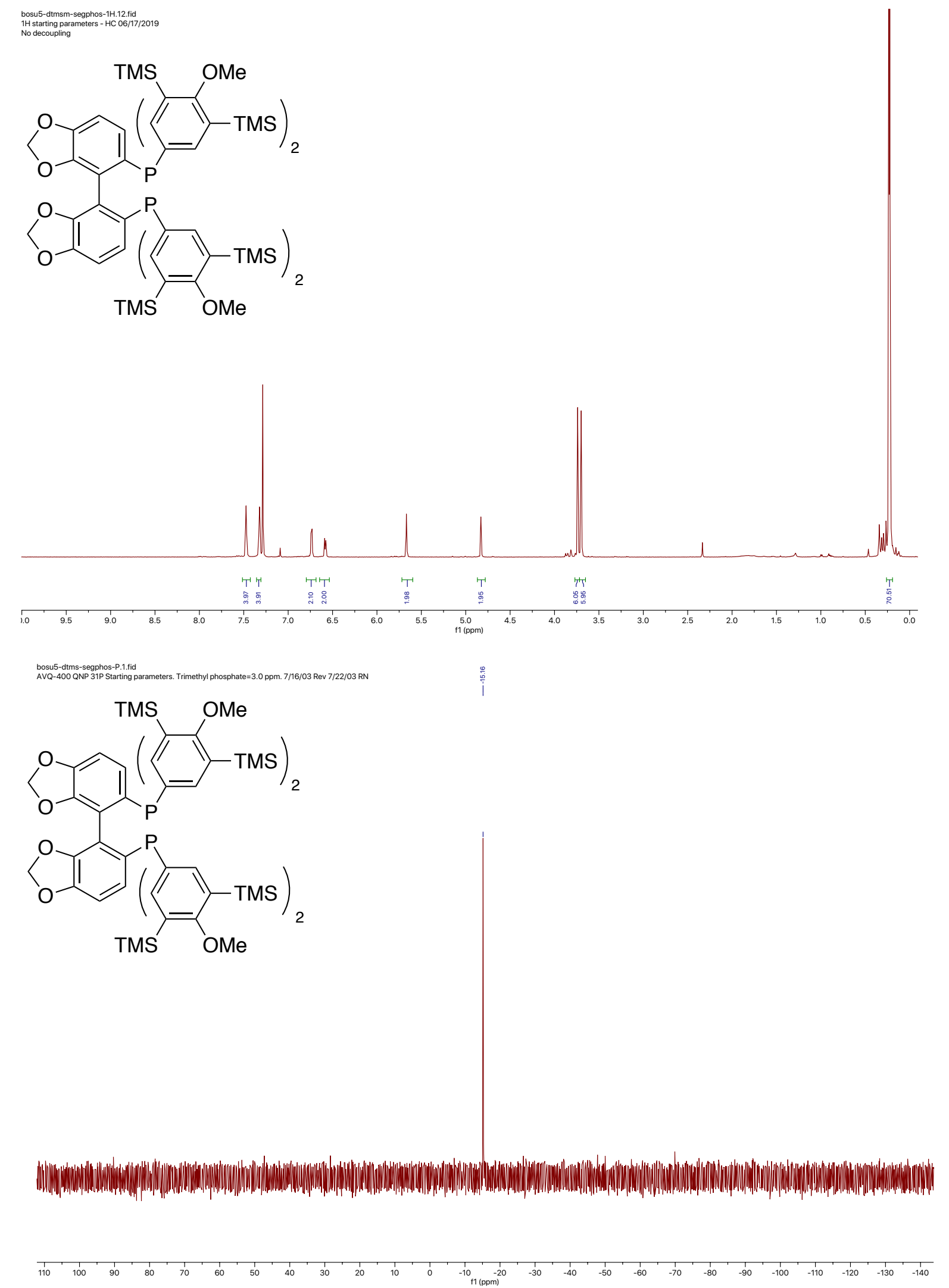


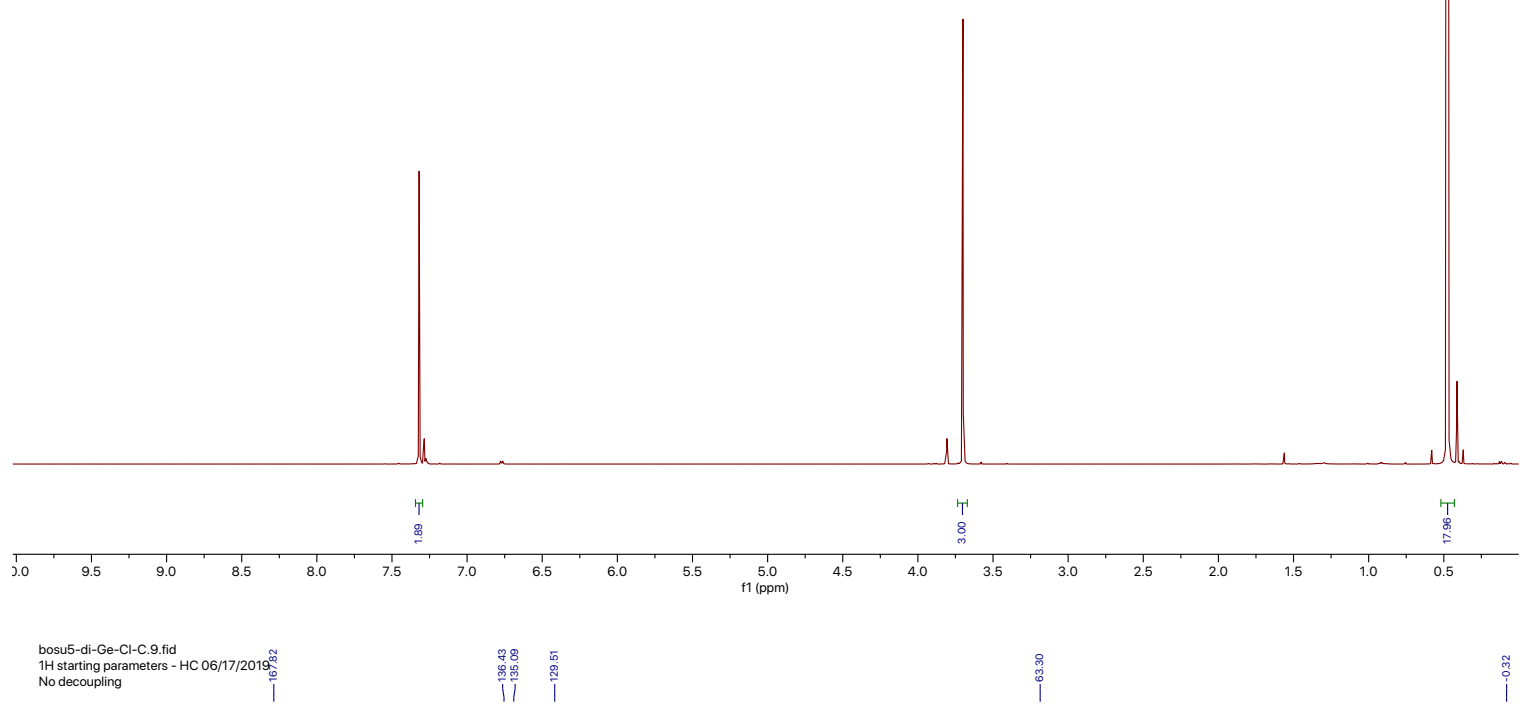<smiles>COc1c(C(C)(C)C)cc(Cl)cc1C(C)(C)C</smiles>

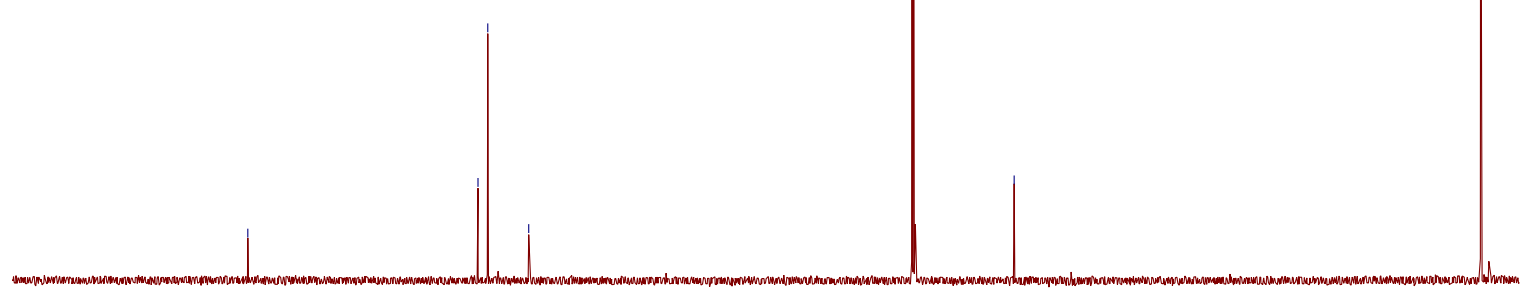




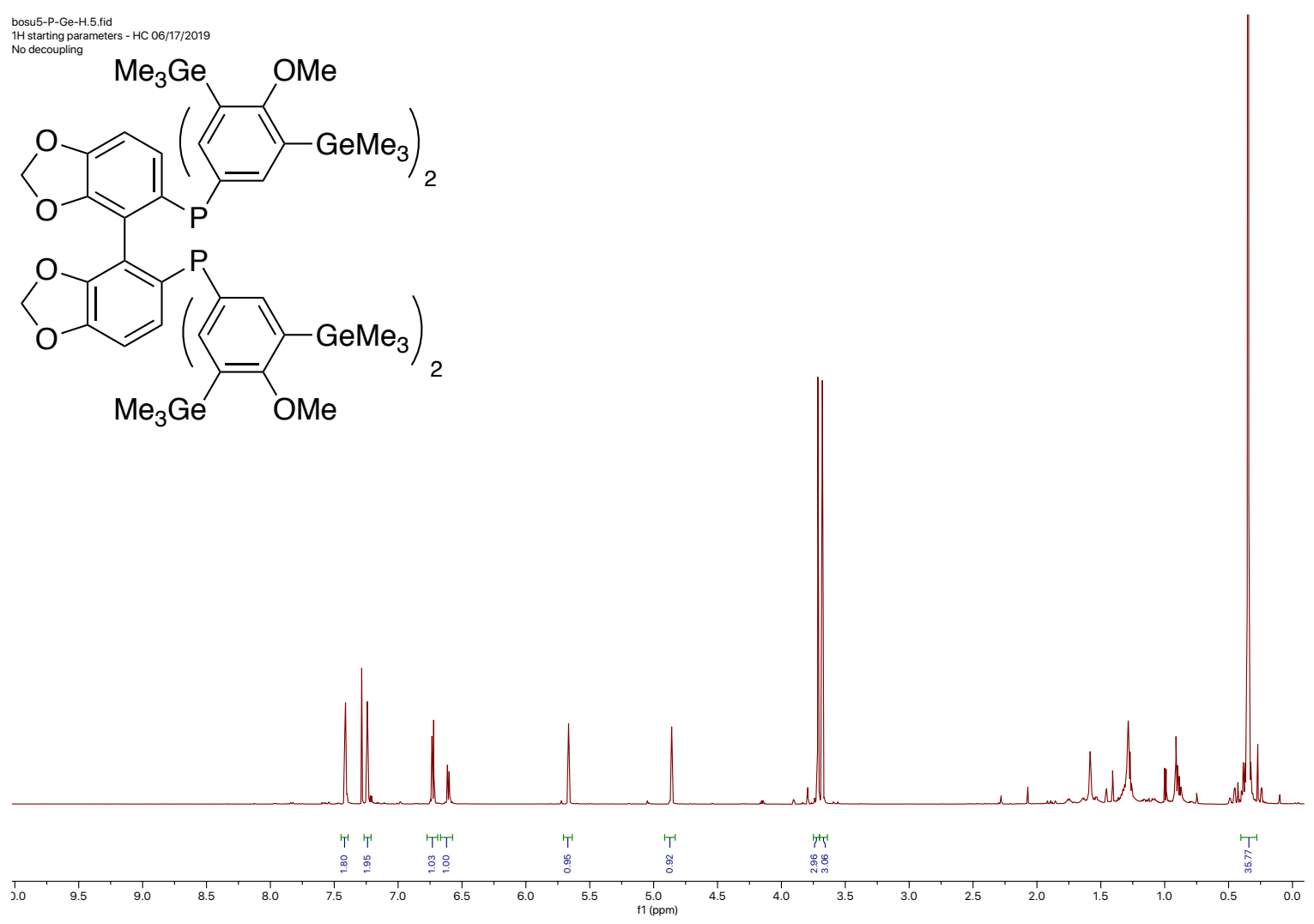

bosu5-P-Ge-P.1.fid
AVQ-400 QNP 31P Sta

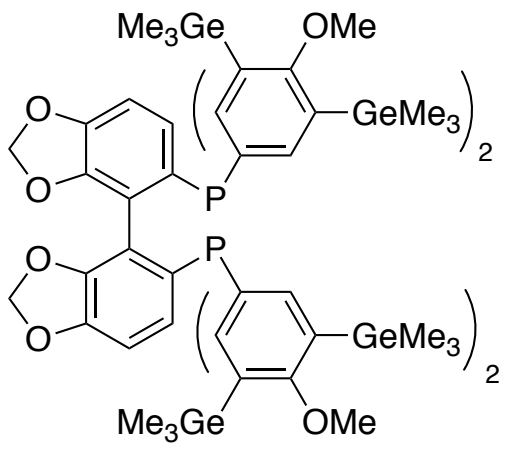

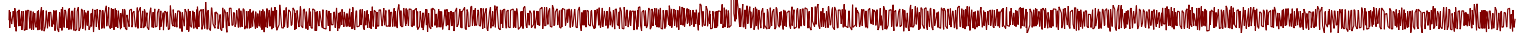

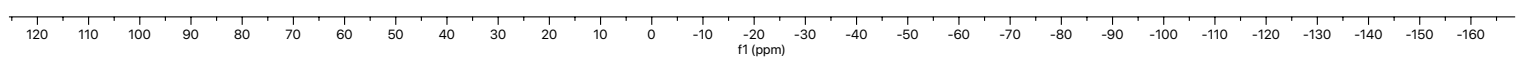




\section{References}

1. Xi, Y.; Hartwig, J. F. J. Am. Chem. Soc. 2016, 138, 6703.

2. Sevov, C. S.; Hartwig, J. F. J. Am. Chem. Soc. 2014, 136, 10625.

3. Berhal, F.; Esseiva, O.; Martin, C.-H.; Tone, H.; Genet, J.-P.; Ayad, T.; Ratovelomanana-Vidal, V. Org. Lett. 2011, 13, 2806.

4. McGhee, A. M. ; Kiziriana, J.-C.; Procter, D. J. Org. Biomol. Chem. 2007, 5, 1021.

5. Nordin, O.; Nguyen, B.-V.; Vörde, C.; Hedenström , E.; Högberg, H.-E. J. Chem. Soc., Perkin Trans 1 2000, 367.

6. Brenna, E.; Gatti, F.G.; Monti, D.; Parmeggiani, F.; Sacchetti, A. ChemCatChem 2012, 4, 653.

7. Murakata, M.; Tsutsui, H.; Hoshino, H. Heterocycles 1997, 46, 517.

8. Gaunt, M. J.; Jessiman, A. S.; Orsini, P.; Tanner, H. R.; Hook, D. F.; Ley, S. V. Org. Lett. 2003, 5, 4819.

9. Gembus, V.; Karmazin, L; Uguen, D.; Zoller, T. Bull. Chem. Soc. Jpn. 2019, 92, 359.

10. Jang, W. J.; Song, S. M.; Moon, J. H.; Lee, J. Y.; Yun, J. J. Am. Chem. Soc. 2017, 139, 13660.

11. Zhu, S.; Buchwald, S. L. J. Am. Chem. Soc. 2014, 136, 15913.

12. Frisch, M. J.; Trucks, G. W.; Schlegel, H. B.; Scuseria, G. E.; Robb, M. A.; Cheeseman, J. R.; Scalmani, G.; Barone, V.; Mennucci, B.; Petersson, G. A.; Nakatsuji, H.; Caricato, M.; Li, X.; Hratchian, H. P.; Izmaylov, A. F.; Bloino, J.; Zheng, G.; Sonnenberg, J. L.; Hada, M.; Ehara, M.; Toyota, K.; Fukuda, R.; Hasegawa, J.; Ishida, M.; Nakajima, T.; Honda, Y.; Kitao, O.; Nakai, H.; Vreven, T.; Montgomery, J. A., Jr.; ; Peralta, J. E.; Ogliaro, F.; Bearpark, M.; Heyd, J. J.; Brothers, E.; Kudin, K. N.; Staroverov, V. N.; Kobayashi, R.; Normand, J.; Raghavachari, K.; Rendell, A.; Burant, J. C.; Iyengar, S. S.; Tomasi, J.; Cossi, M.; Rega, N.; Millam, N. J.; Klene, M.; Knox, J. E.; Cross, J. B.; Bakken, V.; Adamo, C.; Jaramillo, J.; Gomperts, R.; Stratmann, R. E.; Yazyev, O.; Austin, A. J.; Cammi, R.; Pomelli, C.; Ochterski, J. W.; Martin, R. L.; Morokuma, K.; Zakrzewski, V. G.; Voth, G. A.; Salvador, P.; Dannenberg, J. J.; Dapprich, S.; Daniels, A. D.; Farkas, O.; Foresman, J. B.; Ortiz, J. V.; Cioslowski, J.; Fox, D. J. Gaussian 09, Revision D.01; Gaussian, Inc.: Wallingford, CT, 2013.

13 Shao, Y.; Gan, Z.; Epifanovsky, E.; Gilbert, A. T. B.; Wormit, M.; Kussmann, J.; Lange, A. W.; Behn, A.; Deng, J.; Feng, X.; Ghosh, D.; Goldey, M.; Horn, P. R.; Jacobson, L. D.; Kaliman, I.; Khaliullin, R. Z.; Kuś, T.; Landau, A.; Liu, J.; Proynov, E. I.; Rhee, Y. M.; Richard, R. M.; Rohrdanz, M. A.; Steele, R. P.; Sundstrom, E. J.; Woodcock, H. L.; Zimmerman, P. M.; Zuev, D.; Albrecht, B.; Alguire, E.; Austin, B.; Beran, G. J. O.; Bernard, Y. A.; Berquist, E.; Brandhorst, K.; Bravaya, K. B.; Brown, S. T.; Casanova, D.; Chang, C.-M.; Chen, Y.; Chien, S. H.; Closser, K. D.; Crittenden, D. L.; Diedenhofen, M.; DiStasio, R. A.; Do, H.; Dutoi, A. D.; Edgar, R. G.; Fatehi, S.; Fusti-Molnar, L.; Ghysels, A.; Golubeva-Zadorozhnaya, A.; Gomes, J.; Hanson-Heine, M. W. D.; Harbach, P. H. P.; Hauser, A. W.; Hohenstein, E. G.; Holden, Z. C.; Jagau, T.-C.; Ji, H.; Kaduk, B.; Khistyaev, K.; Kim, J.; Kim, J.; King, R. A.; Klunzinger, P.; Kosenkov, D.; Kowalczyk, T.; Krauter, C. M.; Lao, K. U.; Laurent, A. D.; Lawler, K. V.; Levchenko, S. V.; Lin, C. Y.; Liu, F.; Livshits, E.; Lochan, R. C.; Luenser, A.; Manohar, P.; Manzer, S. F.; Mao, S.-P.; Mardirossian, N.; Marenich, A. V.; Maurer, S. A.; Mayhall, N. J.; 
Neuscamman, E.; Oana, C. M.; Olivares-Amaya, R.; O’Neill, D. P.; Parkhill, J. A.; Perrine, T. M.; Peverati, R.; Prociuk, A.; Rehn, D. R.; Rosta, E.; Russ, N. J.; Sharada, S. M.; Sharma, S.; Small, D. W.; Sodt, A. Mol. Phys. 2014, 113, 184.

14. Towns, J.; Cockerill, T.; Dahan, M.; Foster, I.; Gaither, K.; Grimshaw, A.; Hazlewood, V.; Lathrop, S.; Lifka, D.; Peterson, G. D.; Roskies, R.; Scott, J. R.; Wilkins-Diehr, N. Comput. Sci. Eng. 2014, 16, 62.

15. Chai, J. D.; Head-Gordon, M. Phys. Chem. Chem. Phys. 2008, 10, 6615.

16. Ribeiro, R. F.; Marenich, A. V.; Cramer, C. J.; Truhlar, D. G. J. Phys. Chem. B 2011, 115, 14556.

17. Funes-Ardoiz, I.; Paton, R. S. GoodVibes: GoodVibes v1.0.2. http://doi.org/10.5281/zenodo.595246, 2016.

18. Marenich, A. V.; Cramer, C. J.; Truhlar, D. G. J. Phys. Chem. B 2009, 113, 6378.

19. (a) Lu, G.; Liu, R. Y.; Yang, Y.; Fang, C.; Lambrecht, D. S.; Buchwald, S. L.; Liu, P. J. Am. Chem. Soc. 2017, 139, 16548; (b) Thomas, A. A.; Speck, K.; Kevlishvili, I.; Lu, Z.; Liu, P.; Buchwald, S. L. J. Am. Chem. Soc. 2018, 140, 13976; (c) Deng, L.; Fu, Y.; Lee, S. Y.; Wang, C.; Liu, P.; Dong, G. J. Am. Chem. Soc. 2019, 141, 16260; (d) Qi, X.; Kohler, D. G.; Hull, K. L.; Liu, P. J. Am. Chem. Soc. 2019, 141, 11892. 